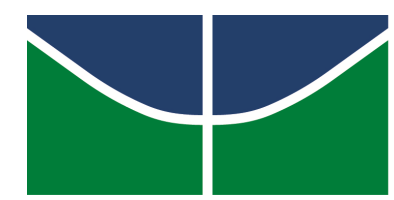

UNIVERSIDADE DE BRASÍLIA

INSTITUTO DE PSICOLOGIA

Programa de Pós-graduação em Processos de Desenvolvimento Humano e Saúde

DESENVOLVIMENTO DE COMPETÊNCIAS NUMÉRICAS E INCLUSÃO ESCOLAR: UMA PESQUISA DE INTERVENÇÃO COM UM ADOLESCENTE COM PARALISIA CEREBRAL

Aline de Amorim Pinto Chiesa

Brasília, dezembro de 2015 
Ficha catalográfica elaborada automaticamente, com os dados fornecidos pelo(a) autor(a)

Chiesa, Aline Amorim Pinto

Desenvolvimento de competências numéricas e inclusão escolar: uma pesquisa de intervenção com um adolescente com paralisia cerebral / Aline Amorim Pinto Chiesa; orientador Maria Helena Fávero. -Brasilia, 2015.

$249 \mathrm{p}$.

Dissertação (Mestrado - Mestrado em Processos de Desenvolvimento Humano e Saúde) -- Universidade de Brasilia, 2015.

1. Inclusão escolar. 2. Paralisia cerebral. 3. Intervenção psicopedagógica. 4. Matemática. 5. Deficiência intelectual. I. Fávero, Maria Helena, orient. II. Título. 


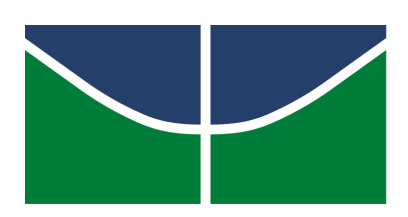

UNIVERSIDADE DE BRASÍLIA

INSTITUTO DE PSICOLOGIA

Programa de Pós-graduação em Processos de Desenvolvimento Humano e Saúde DESENVOLVIMENTO DE COMPETÊNCIAS NUMÉRICAS E INCLUSÃO ESCOLAR: UMA PESQUISA DE INTERVENÇÃO COM UM ADOLESCENTE COM PARALISIA CEREBRAL

Aline de Amorim Pinto Chiesa

Dissertação apresentada ao Instituto de Psicologia da Universidade de Brasília, como requisito parcial à obtenção do título de Mestre em Processos de Desenvolvimento Humano e Saúde, área de concentração Processos Educativos e Psicologia Escolar.

Orientadora: Professora Dra. Maria Helena Fávero 
UNIVERSIDADE DE BRASÍLIA

INSTITUTO DE PSICOLOGIA

DISSERTAÇÃO DE MESTRADO APROVADA PELA SEGUINTE BANCA

EXAMINADORA:

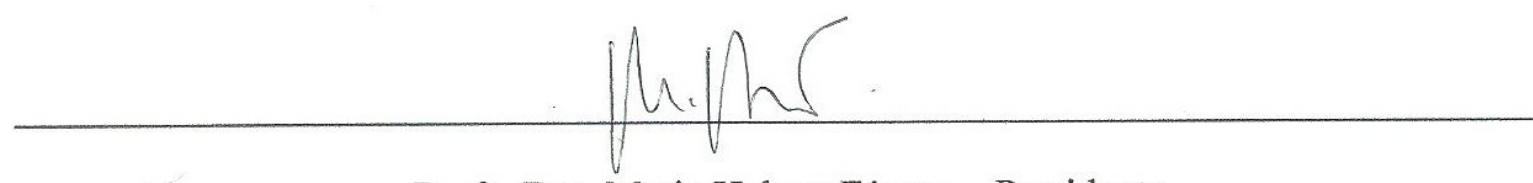

Profa. Dra. Maria Helena Fávero - Presidente

Universidade de Brasília-UNB

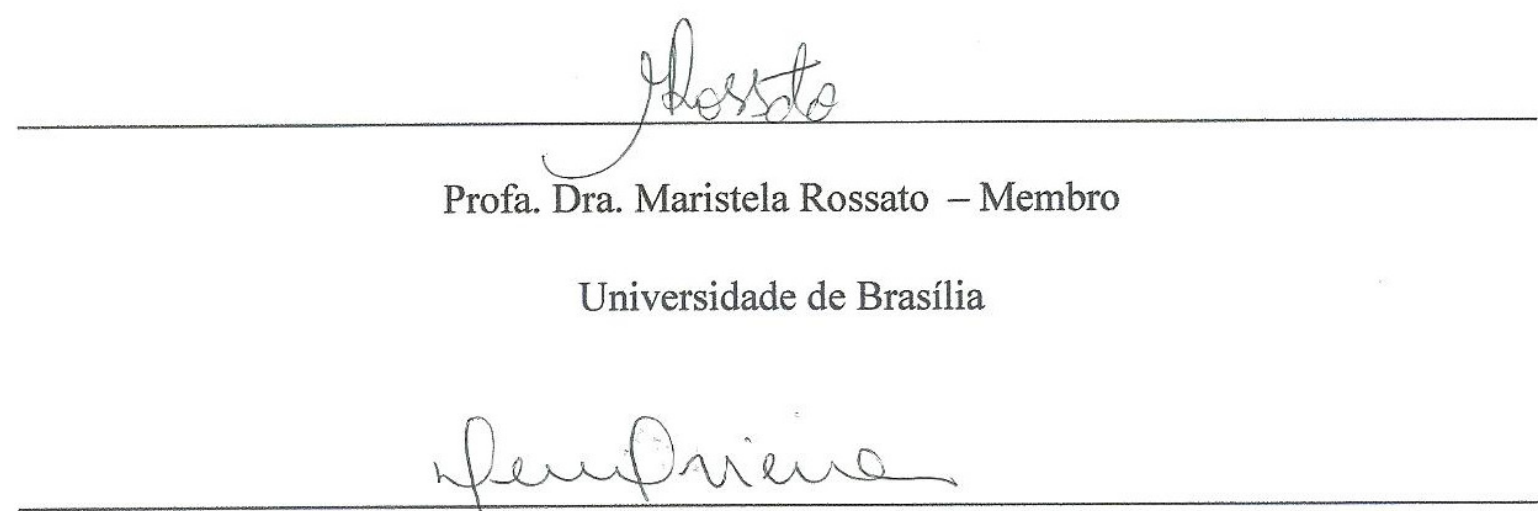

Profa. Dra. Denise de Oliveira Vieira - Membro

Secretaria de Educação do Distrito Federal; Instituto Federal de Brasília

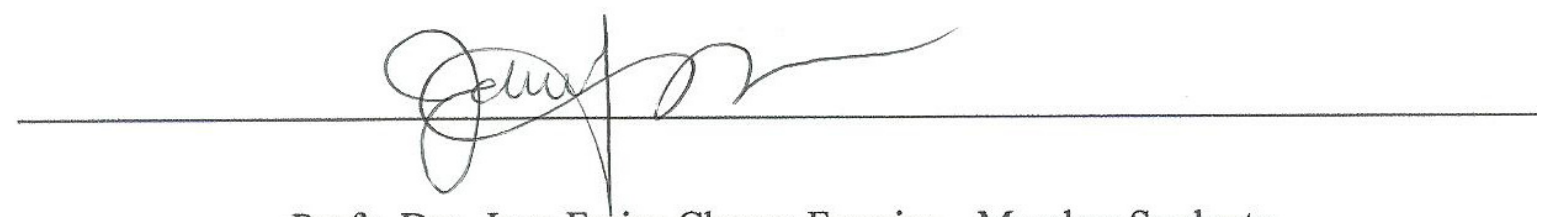

Profa. Dra. Jane Farias Chagas Ferreira - Membro Suplente

Universidade de Brasília

Brasília, dezembro de 2015 


\section{Agradecimentos}

Dentre as coisas que aprendi, durante esse curso de mestrado, está a crença inabalável no desenvolvimento humano. Grande parte desse aprendizado veio da relação com minha orientadora, a professora Maria Helena Fávero. Além disso, ressalto todas as aprendizagens relacionadas a elaboração e condução de uma pesquisa científica.

Estendo meus agradecimentos aos demais professores e funcionários da Universidade de Brasília que fizeram parte do meu trajeto no Programa de Pós-Graduação em Desenvolvimento Humano e Saúde.

Acrescento ainda meus agradecimentos aos colegas de profissão do Programa de Reabilitação Infantil, Enfermaria de Pediatria e do Programa de Reabilitação Neurológica da Rede Sarah de Hospitais, que apoiaram a realização desse curso de mestrado.

Agradeço profundamente ao meu marido, Juscelino Cavalcante Mota Júnior, cujo amor e companheirismo foram demonstrados de tantas formas, quantos foram os desafios enfrentados. 


\section{Resumo}

A Declaração de Salamanca defende os princípios, as políticas e as práticas para as necessidades educacionais especiais e a inclusão de crianças e jovens com necessidades educacionais especiais no ensino regular e fundamenta o conceito de escola inclusiva. A revisão bibliográfica a respeito da inclusão escolar em periódicos de psicologia nas bases de dados PePSIC e SciELO, entre 2004 e 2013, apontou, após um procedimento de análise e síntese, as seguintes categorias: 1- artigos focados nas questões teórico-conceituais da inclusão educacional; 2- artigos referentes a concepções sobre a inclusão educacional; 3artigos referentes à discussão sobre a prática escolar inclusiva; 4- artigos referentes à relação entre competências profissionais e inclusão escolar. Foi evidenciada a busca de solidificação da base teórica e paradigmática que sustenta a prática educacional inclusiva e evidencia a complexidade que envolve essa prática. A presente dissertação defende a necessidade de pesquisas de intervenção que gerem subsídios para a prática educacional inclusiva e seu foco é o desenvolvimento de competências matemáticas de um estudante com Paralisia Cerebral, incluso no $6^{\circ}$ ano do Ensino Fundamental, na Rede Pública do Distrito Federal. A pesquisa foi desenvolvida em quatro fases: a primeira foi constituída de entrevista semiestruturada, segundo os seguintes eixos: concepções do estudante acerca de sua história escolar, suas concepções sobre a escola, noções temporais e espaciais relacionadas ao cotidiano escolar, relações sociais, concepções sobre sua escolaridade, competências e dificuldades escolares, em especial em matemática; a segunda consistiu de avaliação das capacidades e das dificuldades relacionadas aos conhecimentos numéricos, através da Épreuve Conceptuelle de Résolution des Problèmes Numériques - ECPN (Groupe Cimete, 1995); na terceira fase realizou-se um procedimento de intervenção de natureza psicopedagógica, baseado na proposta de Fávero (2002), que articula a avaliação das competências e dificuldades matemáticas, a sistematização de cada uma das sessões de trabalho - em termos de objetivos e descrição das atividades propostas - e uma análise minuciosa do desenvolvimento das atividades para cada sessão, explicitando: a sequência de ações do sujeito, o significado destas ações em relação as suas aquisições de estruturas conceituais, o tipo de mediação estabelecida entre o adulto e o sujeito. Dessa forma, cada sessão de intervenção foi transcrita na íntegra e analisada, segundo a proposta de Fávero (2002). Na quarta fase, ocorreu a avaliação das capacidades e dificuldades ao término da intervenção, com a retomada da Prova ECPN. Os resultados apontaram para a pertinência de se considerar a relação entre as dificuldades e competências presentes no desenvolvimento humano. Foram evidenciados indícios de desenvolvimento psicológico do participante em suas enunciações que, nas primeiras sessões de intervenção, caracterizavam-se pela repetição da fala da pesquisadora. Com o desenvolvimento das sessões de intervenção, suas enunciações foram substituídas pela fala consigo mesmo, o que caracterizou uma forma de organizar seu pensamento. Evidenciou-se também a dificuldade de organização perceptual do participante, o que pode ter dificultado o desenvolvimento de suas competências matemáticas na escola, à medida que podem não ter recebido a devida atenção em seu processo de escolarização. Conclui-se pela validade da metodologia utilizada em face do objeto de estudo e sugere-se a pesquisa e a prática psicopedagógica como auxiliares relevantes para o processo de inclusão escolar.

Palavras-chave: Inclusão escolar, paralisia cerebral, intervenção psicopedagógica. 


\begin{abstract}
The Salamanca Statement advocates the principles, policies and practices for special educational needs and the inclusion of children and young people with special educational needs in regular education; it is the basis of the concept of inclusive school. After a process of analysis and synthesis, the literature review about school inclusion in psychology journals in the PePSIC and SciELO databases between 2004 and 2013 pointed out the following categories: 1-articles focused on theoretical and conceptual issues of educational inclusion; 2-articles referring to conceptions of educational inclusion; 3-articles referring to the discussion on inclusive school practice; 4-articles on the relationship between professional competences and school inclusion. The search for consolidating the theoretical and paradigmatic basis supporting inclusive educational practice was highlighted and it shows the complexity involved in that practice. This dissertation advocates the need for intervention research that contributes for inclusive educational practice. Its focus is the development of mathematical competences by a student with Cerebral Palsy, included in the $6^{\text {th }}$ year of Elementary School, in the public school system of Brazil's Federal District. The research was conducted in four stages. The first stage consisted of a semi-structured interview, according to the following axes: the student's views about his school history; his views about school; temporal and spatial notions related to everyday school life; social relations; views on his schooling, competences and learning difficulties, especially in mathematics. The second stage consisted of assessment of abilities and difficulties related to numerical knowledge using Épreuve Conceptuelle de Résolution des Problèmes Numériques - ECPN (Groupe Cimete, 1995). A psychological and pedagogical intervention procedure was held in the third stage, based on Favero's (2002) proposal articulating assessment of competences and mathematical difficulties, systematization of each of the working sessions - in terms of aims and description of proposed activities - and a thorough analysis of the development of activities for each session, thus explaining: the sequence of the subject's actions, the meaning of those actions regarding his acquisition of conceptual structures, and the type of mediation established between the adult and the subject. Thus, each intervention session was fully transcribed and analyzed as proposed by Favero (2002). In the fourth stage, abilities and difficulties were assessed at the end of the intervention, with the resumption of the ECPN Test. The results pointed out the relevance of considering the relationship between difficulties and competences present in human development. Indications of the participant's psychological development were seen in his utterances, which, in the first sessions of intervention, were characterized by the repetition of the researcher's speech. With the development of intervention sessions, his utterances were replaced by talking to himself, which was a way to organize his thinking. The participant's difficulty for perceptual organization was also seen, which may have hindered the development of his mathematical competences at school, since they may not have received due attention during his schooling process. We conclude for the validity of the methodology used in face of the objects of study and suggest research and psychopedagogical practice as relevant aids in school inclusion.
\end{abstract}

Keywords: School inclusion, Cerebral Palsy, Psychopedagogical intervention. 


\section{Sumário}

Agradecimentos........................................................................ V

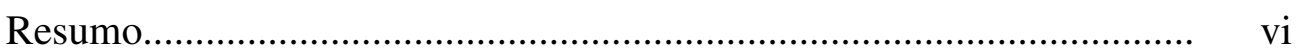

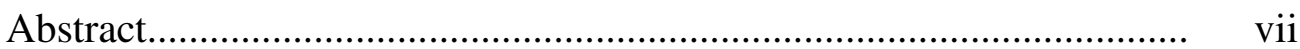

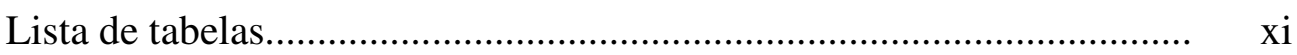

Lista de figuras........................................................................

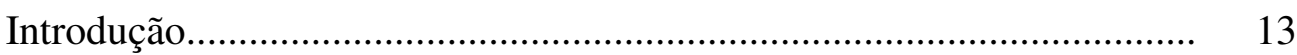

Parte I Fundamentação teórica.................................................................. 15

1. A educação inclusiva e as práticas escolares: uma revisão nos periódicos brasileiros...................................................................... 15

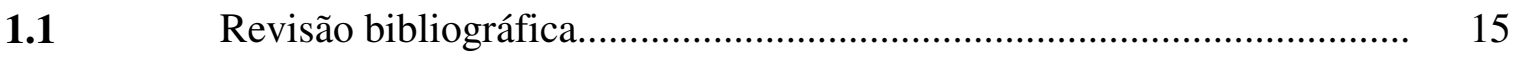

1.1.1 A primeira categoria: artigos que abordam discussão teórica e

1.1.1.1 Análise e discussão da primeira categoria de publicações....................... 28

1.1.2 A segunda categoria: artigos que se referem às concepções sobre

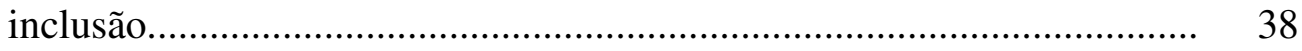

1.1.2.1 Análise e discussão da segunda categoria de publicações......................... 49

1.1.3 A terceira categoria de publicações: artigos sobre a prática inclusiva.... 57

1.1.3.1 Análise e discussão da terceira categoria de publicações......................... 62

1.1.4 A quarta categoria de publicações: formação profissional e inclusão..... 65

1.1.4.1 Análise e discussão da quarta categoria de publicações............................ 68

1.1.5 Discussão geral das categorias de publicações e conclusões.................... 69

1.2 Inclusão escolar, paralisia cerebral e aprendizagem da matemática........ 79

1.3 Transição para a vida adulta............................................................... 85

Parte II O estudo: pesquisa de intervenção e competências numéricas 89

2.1 O problema e o método.................................................................... 89

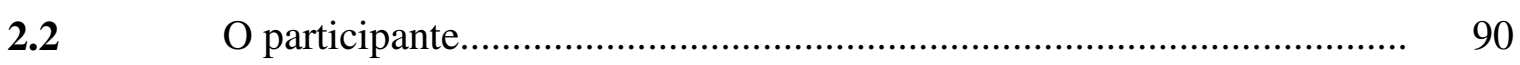

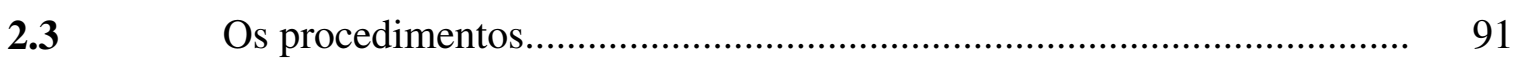

2.3.1 Procedimentos de coleta de dados.................................................... 91

2.3.2 Procedimentos de análise de dados........................................................ 93

2.4 Resultados obtidos em cada fase......................................................... 95

2.4.1 O que narra a voz de G.............................................................. 96

2.4.2 Avaliação psicopedagógica do conhecimento numérico.......................... 99

2.4.2.1 Discussão da avaliação psicopedagógica: Competências e dificuldades de G. 
2.4.3 As sessões de intervenção psicopedagógica.............................................. 106

2.4.3.1 Primeira sessão de intervenção psicopedagógica...................................... 107

2.4.3.1.1 Desenvolvimento, resultados e discussão da primeira sessão de intervenção psicopedagógica.

2.4.3.2 Segunda sessão de intervenção psicopedagógica.

2.4.3.2.1 Desenvolvimento, resultados e discussão da segunda sessão de intervenção psicopedagógica.

2.4.3.3 Terceira sessão de intervenção psicopedagógica.

2.4.3.3.1 Desenvolvimento, resultados e discussão da terceira sessão de intervenção psicopedagógica.

2.4.3.4 Quarta sessão de intervenção psicopedagógica.

2.4.3.4.1 Desenvolvimento, resultados e discussão da quarta sessão de intervenção psicopedagógica.

2.4.3.5 Quinta sessão de intervenção psicopedagógica...

2.4.3.5.1 Desenvolvimento, resultados e discussão da quinta sessão de intervenção psicopedagógica.

2.4.3.6 Sexta sessão de intervenção psicopedagógica.

2.4.3.6.1 Desenvolvimento, resultados e discussão da sexta sessão de intervenção psicopedagógica.

2.4.3.7 Sétima sessão de intervenção psicopedagógica.

2.4.3.7.1 Desenvolvimento, resultados e discussão da sétima sessão de intervenção psicopedagógica.

2.4.3.8 Oitava sessão de intervenção psicopedagógica

2.4.3.8.1 Desenvolvimento, resultados e discussão da oitava sessão de intervenção psicopedagógica.

2.4.3.9 Nona sessão de intervenção psicopedagógica.

2.4.3.9.1 Desenvolvimento, resultados e discussão da nona sessão de intervenção psicopedagógica.

2.4.3.10 Décima sessão de intervenção psicopedagógica.

2.4.3.10.1 Desenvolvimento, resultados e discussão da décima sessão de intervenção psicopedagógica.

2.4.3.11 Décima primeira sessão de intervenção psicopedagógica.

2.4.3.11.1 Desenvolvimento, resultados e discussão da décima primeira sessão de intervenção psicopedagógica.

2.4.3.12 Décima segunda sessão de intervenção psicopedagógica.

2.4.3.12.1 Desenvolvimento, resultados e discussão da décima segunda sessão de intervenção psicopedagógica.

2.4.3.13 Décima terceira sessão de intervenção psicopedagógica. 
2.4.3.13.1 Desenvolvimento, resultados e discussão da décima terceira sessão de intervenção psicopedagógica.

2.4.3.14 Décima quarta sessão de intervenção psicopedagógica.

2.4.3.14.1 Desenvolvimento, resultados e discussão da décima quarta sessão de intervenção psicopedagógica.

2.4.3.15 Décima quinta sessão de intervenção psicopedagógica.

2.4.3.15.1 Desenvolvimento, resultados e discussão da décima quinta sessão de intervenção psicopedagógica.

2.4.3.16 Décima sexta sessão de intervenção psicopedagógica

2.4.3.16.1 Desenvolvimento, resultados e discussão da décima sexta sessão de intervenção psicopedagógica.

2.4.3.17 Décima sétima sessão de intervenção psicopedagógica........

2.4.3.17.1 Desenvolvimento, resultados e discussão da décima sétima sessão de intervenção psicopedagógica.

Anexo 1 Termo de Consentimento Livre e Esclarecido...

Anexo 2 Termo de Assentimento..

Anexo 3 Autorização CEP para a realização da pesquisa......

Anexo 4 Épreuve Conceptuelle de Résolution des Problèmes 


\section{Lista de Tabelas}

Tabela 1 Artigos que abordam discussão teórica e conceitual sobre inclusão.... 18

Tabela 2 Artigos que se referem às concepções sobre a inclusão......................... 38

Tabela 3 Artigos sobre a prática escolar inclusiva............................................. 57

Tabela 4 Formação profissional e inclusão........................................................... 65

Tabela 5 Análise dos atos da fala retirados da entrevista semiestruturada........... 99

Tabela 6 Descrição da prova ECPN, desempenho do participante e análise........ 101

Tabela 7 Análise dos atos da fala retirados da terceira sessão de intervenção..... 121

Tabela 8 Análise dos atos da fala retirados da décima primeira sessão de 175 intervenção........................................................................................

Tabela 9 Descrição da prova ECPN, desempenho do participante e análise........ 200 


\section{Lista de Figuras}

Figura 1 Registro da organização dos palitos em fileiras............................... 110

Figura 2 Colagem de palitos e agrupamentos circulados............................... 115

Figura 3 Registro de colagem de palitos.................................................... 120

Figura 4 Registro com operações convencionais de multiplicação................... 126

Figura 5 Registro dos palitos colados apresentado pela pesquisadora.............. 130

Figura 6 Registro da operação de soma ….................................................... 131

Figura $7 \quad$ Registro das somas sucessivas........................................................ 133

Figura 8 Registro de operações de multiplicação................................................ 134

Figura 9 Registro das operações de adição................................................... 145

Figura 10 Registro de operação de adição....................................................... 146

Figura 11 Lista de convidados e de itens a serem servidos na festa................... 151

Figura 12 Algoritmo de soma de parcelas..................................................... 153

Figura 13 Registro de unidades utilizadas para auxiliar na soma de parcelas..... 154

Figura 14 Representação da situação-problema dos brigadeiros........................ 159

Figura 15 Operação de multiplicação relacionada a situação-problema dos 161 brigadeiros.....

Figura 16 Registro das situações-problemas da coxinha e do pão de queijo....... 167

Figura 17 Registro da quantidade de copos que podem ser enchidos com 2,5 1 174 de água.....

Figura 18 Organização linear dos copos numerados....................................... 178

Figura 19 Registro sobre o enchimento dos copos....................................... 180

Figura 20 Primeiro algoritmo referente à situação-problema de compra do bolo 187

Figura 21 Segundo algoritmo referente à situação-problema de compra do bolo 188 


\section{Introdução}

No século XX e, sobretudo após a II Guerra Mundial, observa-se um movimento internacional no qual o conceito de dignidade humana passou a ser tomado de forma entrelaçada aos direitos civis (Habermans, 2010) e pode-se dizer que essa foi a base da Educação Inclusiva. Ela foi construída ao longo de décadas e culminou com a Declaração de Salamanca (1994), na qual são defendidos princípios, políticas e práticas para as chamadas necessidades educacionais especiais. Assim, nesse documento, além de ser recomendada a inclusão de crianças e jovens com necessidades educacionais especiais no ensino regular, foi introduzido o conceito de escola inclusiva e se defendeu o apoio pedagógico no espaço escolar. A ratificação da Declaração de Salamanca, no Brasil, instituiu o acesso de alunos com deficiência às escolas e classes comuns da rede regular de ensino (Brasil, 2007). Essa normativa instituiu também o apoio contínuo, seja na adaptação dos estudantes nas classes regulares, seja no desenvolvimento de programas suplementares de apoio pedagógico na escola.

O consenso das publicações nacionais e internacionais, neste século XXI, sobre esse assunto, aponta para um grande desafio: o desenvolvimento de práticas escolares que viabilizem, efetivamente, a inclusão educacional (Kurth \& Mastergeorge, 2009; Engelbrecht, 2013). A adequação curricular, uma das formas de efetivação dos princípios inclusivos, tem sido estudada (Oliveira \& Leite, 2011; Kurth \& Keegan, 2012; Engelbrecht, 2013), mas ainda permanece o desafio referente à necessidade de uma mudança de concepção para considerar que o próprio desenvolvimento psicológico humano, para toda e qualquer pessoa, é fruto de um processo particular (Kurth \& Mastergeorge, 2009; Engelbrecht, 2013). No presente trabalho, esse mesmo argumento será defendido retomando a contribuição da análise de Fávero (1994, 2005, 2011) que destaca os pressupostos básicos da Psicologia do Desenvolvimento, em oposição ao modelo médico 
que prioriza as diferenças e incapacidades (Fávero \& Salim, 2001; Fávero \& Oliveira, 2004; Fávero \& Pimenta, 2006). A análise de Garrido e Moysés (2011) segue essa direção e contribui para o seu fundamento.

A proposta de Fávero (2005), e dos autores anteriormente citados, converge para as publicações internacionais mais recentes, sendo que a defesa é levar em conta as particularidades individuais e o suas repercussões no desenvolvimento de novas competências, de modo a ultrapassar o raciocínio circular de causalidade (Engelbrecht, 2013). Essa proposta é particularmente interessante quando se trata do desenvolvimento de competências matemáticas no processo de escolarização, visto que, para essa área do conhecimento, se vinculam concepções particulares relacionadas à competência matemática dita racional e abstrata (Fávero \& Carneiro Soares, 2002; Fávero \& Oliveira, 2004). Nossa prática profissional atesta esse mesmo dado.

Diante do exposto até aqui, elegeu-se como objeto deste trabalho o estudo do desenvolvimento de competências matemáticas de um adolescente com paralisia cerebral, aluno do $6^{\circ}$ ano do Ensino Fundamental. Trata-se de uma pesquisa de intervenção psicopedagógica, com fundamentação em Fávero $(2005,2011)$ e colaboradores (Fávero \& Pina Neves, 2011, por exemplo).

A primeira parte desse trabalho discute a educação inclusiva e as práticas escolares através de uma revisão de literatura, sendo que suas principais conclusões articulam-se com os demais temas abordados: a paralisia cerebral, a aprendizagem da matemática e a transição para a vida adulta. A segunda parte do trabalho dedica-se à descrever o desenvolvimento da pesquisa, sendo apresentados o problema e o método, o participante, os procedimentos de coleta e análise de dados, as sessões de intervenção psicopedagógica, suas análises e discussões, a discussão geral do estudo e as considerações finais, em que se reflete sobre as contribuições desse trabalho. 


\section{Parte I - Fundamentação Teórica}

\section{A Educação Inclusiva e as Práticas Escolares: Uma Revisão nos Periódicos}

\section{Brasileiros}

Nesta primeira parte, são apresentados e discutidos aspectos relevantes para a compreensão e para a contextualização do objeto de estudo deste trabalho. A primeira seção traz uma revisão bibliográfica acerca da inclusão escolar nos periódicos de psicologia e a relação entre os principais resultados dessa revisão e o objeto de estudo da pesquisa. $\mathrm{Na}$ segunda seção, é abordada a questão da matemática e a inclusão escolar, além dos conceitos de paralisia cerebral e de número. A terceira seção, desta primeira parte, trata da transição para a vida adulta de forma relacionada aos tópicos anteriormente mencionados e apresenta os objetivos desta pesquisa.

\subsection{Revisão Bibliográfica}

Com o objetivo de conhecer o conteúdo das produções publicadas a respeito da inclusão escolar, foi realizada uma pesquisa bibliográfica nas bases de dados PePSIC (Periódicos Eletrônicos de Psicologia) e SciELO (Scientific Electronic Library Online). Foram priorizados os artigos publicados entre 2004 e 2013, em que foram acessados todos os números dos periódicos dessas bases com o objetivo de realizar uma busca por trabalhos relacionados ao tema da inclusão escolar.

Foram recuperados duzentos e três artigos. O refinamento ocorreu pela seleção de textos cujo conteúdo tratasse especificamente de inclusão escolar, sendo os demais excluídos. Permaneceram, após essa fase, sessenta e sete artigos das seguintes revistas: Estilos da Clínica (São Paulo - SP), Psicologia: Teoria e Prática (São Paulo - SP), Psicologia USP (São Paulo SP), Cadernos de Pesquisa (São Paulo - SP), Psicologia da Educação (São Paulo - SP), 
Psicologia em Pesquisa (Juiz de Fora - MG), Revista Brasileira de Crescimento e Desenvolvimento Humano (São Paulo - SP), Revista da SPAGESP (São Paulo - SP), Revista de Psicopedagogia (São Paulo - SP), Construção Psicopedagógica (São Paulo - SP), Psicologia em Revista (Belo Horizonte - MG), Temas em Psicologia (Ribeirão Preto - SP), Estudos de Psicologia (Campinas), Paidéia (Ribeirão Preto - SP), Psico-USF (Itatiba - SP), Psicologia \& Sociedade (Belo Horizonte - MG), Psicologia: Ciência e Profissão (Brasília DF), Psicologia Escolar e Educacional (Maringá - PR), Psicologia: Teoria e Pesquisa (Brasília - DF), Estudos de Psicologia (Natal), Fractal: Revista de Psicologia (Niterói - RJ), Psicologia em Estudo (Maringá-PR), Psicologia: Reflexão e Crítica (Porto Alegre - RS) e Cadernos de Psicopedagogia (São Paulo - SP).

Cada uma das sessenta e sete publicações remanescentes foi lida e submetida a um procedimento de análise e síntese, tal como proposto por Fávero e Gomes de Souza (2001) e retomado por Pina Neves e Fávero (2012), considerando os seguintes aspectos: o objetivo do artigo, a tese defendida, o método utilizado e os principais resultados. Essa análise permitiu a elaboração de uma categorização. As categorias elaboradas foram: 1- Questões teóricoconceituais da inclusão educacional; 2- Concepções sobre a inclusão educacional; 3Discussão sobre a prática escolar inclusiva; 4- Relação entre competências profissionais e inclusão escolar.

Cada categoria foi organizada numa tabela que compreende todos os artigos nela incluídos. As seis colunas das tabelas apresentam, em ordem da direita para a esquerda: na primeira coluna, o contador; na segunda coluna, a referência completa da publicação; na terceira coluna, o objetivo; na quarta coluna, a tese; na quinta coluna, o método e na sexta coluna, as principais conclusões. Ao final de cada tabela é apresentada a discussão da categoria. 
A ordem de apresentação das categorias tem relação decrescente com a quantidade de artigos classificados em cada uma delas. Cada tabela é precedida de uma apresentação e de uma descrição do escopo das revistas das quais os artigos foram retirados. Quando é necessário mencionar aspectos teórico-conceituais dos textos, a linguagem original utilizada pelo autor foi preservada, por exemplo: "portador de deficiência". Ao final, é apresentada uma discussão geral de todas as categorias e uma conclusão a respeito dessa revisão bibliográfica, de forma articulada com o objeto de estudo desta pesquisa. 


\subsubsection{A primeira categoria: artigos que abordam discussão teórica e conceitual} sobre inclusão.

Trinta e dois artigos foram incluídos nesta categoria, que conta com a maior quantidade de publicações. Aqui estão agrupadas as publicações que abordam conceitualmente a inclusão escolar a partir de diversas perspectivas, como a psicanálise, a diversidade do desenvolvimento humano, a psicologia social, a psicologia escolar, a formação e a atuação profissional do psicólogo e a psicopedagogia. Alguns dos artigos que integram essa categoria não se referem especificamente à inclusão escolar, mas abordam a questão da diversidade do desenvolvimento psicológico em interface com a inclusão escolar. Esse é o caso, por exemplo, dos trabalhos de Benedetti e Urt (2008), Gomes (2006) e Facci (2010). Os artigos incluídos nessa categoria estão apresentados na Tabela 1.

\section{Tabela 1}

Artigos que abordam a discussão teórica e conceitual sobre inclusão

\begin{tabular}{|c|c|c|c|c|c|}
\hline & Referência & Objetivos & Tese & Método & Resultados \\
\hline 1 & $\begin{array}{l}\text { Voltolini, } \\
\text { (2004). } \\
\text { Psicanálise } \\
\text { inclusão escolar: } \\
\text { direito } \\
\text { sintoma?. Estilos } \\
\text { da Clinica, } 9(16) \text {, } \\
\text { 92-101. }\end{array}$ & $\begin{array}{lr}\text { Articular } & \text { as } \\
\text { dimensões jurídicas } \\
\text { e condições } \\
\text { subjetivas da } \\
\text { inclusão escolar }\end{array}$ & $\begin{array}{l}\text { A psicanálise na } \\
\text { questão da inclusão } \\
\text { escolar põe em } \\
\text { primeiro plano as } \\
\text { condições } \\
\text { subjetivas, enquanto } \\
\text { o discurso jurídico } \\
\text { tenta delimitar as } \\
\text { condições objetivas } \\
\text { para incluir. }\end{array}$ & $\begin{array}{l}\text { Artigo teórico } \\
\text { construído sobre os } \\
\text { argumentos de que } \\
\text { qualquer } \\
\text { agrupamento, } \\
\text { como a escola, tem } \\
\text { uma constituição } \\
\text { excludente; a na } \\
\text { crença da } \\
\text { racionalidade; e o } \\
\text { reconhecimento } \\
\text { que a exclusão é } \\
\text { efeito estrutural da } \\
\text { sociedade e } \\
\text { transformável até o } \\
\text { ponto de poderem } \\
\text { fluir de maneira } \\
\text { menos conflituosa. }\end{array}$ & $\begin{array}{lr}\text { A exclusão faz parte } \\
\text { da estrutura } & \text { da } \\
\text { existência } & \text { de } \\
\text { agrupamentos. Seus } \\
\text { efeitos não } & \text { são } \\
\text { superáveis por uma } \\
\text { instrução racional, } \\
\text { mas são } \\
\text { transformáveis até o } \\
\text { ponto de poderem } \\
\text { fluir de maneira } \\
\text { menos conflituosa. }\end{array}$ \\
\hline 2 & $\begin{array}{l}\text { Bernardino, L. M. } \\
\text { F. (2007). A } \\
\text { contribuição da } \\
\text { psicanálise para a }\end{array}$ & $\begin{array}{l}\text { Analisar relações } \\
\text { entre psicanálise e } \\
\text { educação especial. }\end{array}$ & $\begin{array}{lr}\text { O trabalho com } \\
\text { crianças } & \text { com } \\
\text { problemas } & \text { de } \\
\text { desenvolvimento }\end{array}$ & $\begin{array}{lr}\text { Dossiê teórico que } \\
\text { trata da relação } \\
\text { ente } & \text { educação } \\
\text { especial } & \text { e }\end{array}$ & $\begin{array}{l}\text { O clínico pode } \\
\text { escolher centrar-se } \\
\text { na correção de uma } \\
\text { função ou pode levar }\end{array}$ \\
\hline
\end{tabular}




atuação no campo
da educação
especial. Estilos
da Clinica,
$12(22), 48-67 .$.

3 Stellin, R. M. R., Discutir as formas

Martins, L. T., de inclusão e do Triandopolis, G. P., \& Costa, Elisa Parente. (2009). Infância e normatização: lugar de criança e o discurso social da inclusão e exclusão. Estilos da Clinica, 14(26), 192-215.

4 Prioste, C. D. (2010). Educação inclusiva $\mathrm{e}$ sexualidade na escola: relato de caso. Estilos da Clinica, 15(1), 14-25.

5 Nicolino, V. F., Atualizar \& Zanotto, M. L. aprofundar e A análise

a comportamento subjetiva o pessoas.

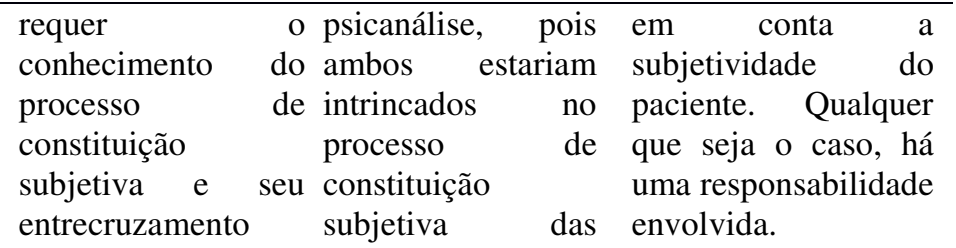
desenvolvimento. social da científico sobre social como normatização e sustentador do inclusão social, lugar do sujeito. pode impedir a Através da história expressão da da infância e da singularidade e escolarização,

excluir do coletivo. mostra a promoção cultural de discursos normatizadores contra a ideia de idades certas para desenvolvimentos esperados.

Refletir sobre Há uma resistência Das reuniões com sexualidade e entre os educadores professores de um educação inclusiva. acerca da grupo de pesquisa, sexualidade, selecionou-se $\mathrm{o}$ especialmente em caso de uma situação de inclusão estudante, de escolar. dezesseis anos, com Síndrome de Down. A dinâmica do grupo compreendia $\mathrm{o}$ relato da professora regente sobre os problemas enfrentados e os demais professores faziam perguntas $\mathrm{e}$ davam sugestões.

B (2010) revis̃o histórica contribui no que se publicados

Revisão histórica sobre análise do refere à inclusão de Journal of Applied de pesquisas em Análise do Comportamento e educação especial/inclusão publicadas no Jaba entre $2001 \mathrm{e}$ 2008. Psicologia: teoria e prática, 12(2), 51-79. comportamento e portadores educação necessidades especial/inclusão. especiais ambiente educação regular
Discursos sociais são construções

históricas influenciam na visão que os sujeitos têm de si e do mundo.

Entre os participantes da pesquisa, havia a crença que a pessoa com deficiência não aprende, não evolui e não muda. Estabelecer regras e esclarecer os limites sobre as manifestações só é saudável como importante para 0 desenvolvimento dos alunos.

\section{Predominam} pesquisas experimentais realizadas na escola do participante. O pesquisador é o agente de mudança/observação do comportamento. O estabelecimento de controle de estímulos de é a abordagem mais adotada. Predomina participantes com desordens do espectro autista, entre 6 a10 anos. sexuais na escola não de Behavior Analysis, entre 2001 e 2008,

no e analisados de segundo os itens: participantes, tipo de pesquisa, delineamento, agente mudança/ observação comportamento, setting, medida do comportamento- 
alvo, procedimento

de intervenção comportamental, tema, objetivo da pesquisa resultados obtidos.

Roriz, T. M. S.,
Amorim, K. S., \& Verificar como os Não há uma Revisão feita no Rossetti-Ferreira, temas inclusão definição

M. C. (2005) social e escolar são sobre comum Medline abordados Inclusão literatura.

na havendo inclusão, PsycINFO e para social/escolar de pessoas com necessidades especiais: múltiplas perspectivas e controversas práticas discursivas. Psicologia USP, 16(3), 167-194.

7 Nabuco, M. E. Analisar as Agrava-se o mal- Pela formulação de (2010). Práticas institucionais e inclusão escolar. Cadernos Pesquisa, 40(139), 63-74. de ins contradições das estar na cultura, mas dois enunciados: políticas educativas as respostas que a "política e suas sociedade fabrica educação" institucionalizações. mudam de natureza "educação e de forma, com política", signos expressivos análise também nas contradições das soluções dadas a políticas educativas ele, como no e discurso da ciência. institucionalizações é apresentada a partir de um referencial teórico da psicánalise de orientação lacaniana

Benedetti, I. \& Urt, S. (2008).
Escola, ética e cultura contemporânea: reflexões sobre a constituição do sujeito que "não aprende". Psic.
Discutir o TDAH A estrutura escolar Artigo teórico que de modo crítico, tradicional fazendo uma leitura encontrado tem contextualiza cenário contexto dificuldade em lidar contemporâneo de contemporâneo em com a diversidade desenvolvimento que se insere a de alunos que nela infantil, escola, analisando a coexistem. constituição do sujeito nesse problematiza $\mathrm{O}$ papel da escola a esse respeito e
Predominam tema sobre linguagem, autocontrole, comportamentos disruptivos, agressão/autolesão e contato inapropriado. $\mathrm{O}$ tema mostrou-se polêmico, alguns, inclusive,

defendendo segregação.

Profissionais de saúde ocupam lugar destacado, mas alguns autores valorizam também atividades fora do setting terapêutico. $\mathrm{O}$ estabelecimento de diagnósticos é visto paradoxalmente: tratamento/rotulação. A cultura é apontada como tendo papel central. Pessoas com necessidades especiais praticamente não são ouvidas.

Respondendo a fluidificação e gozo da era da globalização é que as práticas podem ser reinventadas e as instituições podem ganhar em utilidade social. O que fica para todos como referência e princípio fora da norma é a ética. Por esse caminho podemos fazer circular um discurso que humanize e produza laços sociais. Este é o grande desafio para a educação

É preciso ser criterioso na avaliação e indicação de medicação para TDAH. 
da Ed., 27, 141- cenário e os fatores 155. que influenciam e atuam na dinâmica da relação ensino versus aprendizagem.

9 Areosa, A. L. Mostrar

(2007).

Transpondo

barreiras:

percurso

Portadores

Necessidades

Especiais

longo

tempos.

Psicologia

Pesquisa, 1(1)

08-14.

10 Facci, M. G. Discutir acerca da O aprendizado é Artigo teórico que Dias. (2010). A escola é para poucos?A positividade da escola no desenvolvimento psicológico dos alunos em uma visão vygotskyana. Revista

Psicologia Política, 10(20), 315-328.

11 Gomes,

C., Discutir

Souza, V. L. T. teoricamente (2011). Educação, psicologia escolar e inclusão: aproximações necessárias. Rev. Psicopedagogia, 28(86), 185-93. atuação a Muitas são caminhada pela dificuldades qual passou o enfrentadas de pessoas os Necessidades necessidades

p

pelas percurso histórico com dos portadores de necessidades

classificação dos alunos como tendo distúrbios. Traz dois relatos de caso acerca sobre como a escola e a prática clínica lidam com pessoas com problemas de aprendizagem.

s Artigo teórico que apresenta $\quad 0$

É imprescindível que as organizações efetuem ações de adaptação, visando transformar atos segregacionistas em oportunidades, a fim de contribuir para a melhoria da qualidade de vida nas esferas econômica e social dos PNEs.

Todos os alunos devem ter acesso ao conhecimento científico para se humanizarem. no superiores algumas carências e Psicologia Escolar nacionais desafios da passa pela realizados entre os Psicologia na apropriação de anos de 1999 a da referenciais teóricos 2007, estudante que diz que a escola é para psicológico dos tornar humano, o as minorias e relata alunos, tomando homem precisa se outro caso, de um como referência os apropriar da cultura. estudante com pressupostos da dificuldade de Psicologia Histórico-Cultural aprender, de própria experiência da autora. educação inclusiva. e práticos que disponibilizados na reafirmem processos interativos os Biblioteca Virtual conscientes inconscientes, constitutivos sujeitos em Saúde (BVS) do Centro Latinoe americano e do processo de ensino Caribe de aprendizagem, dentro de uma perspectiva dinâmica e sóciohistórica.
O impulsionamento para a mudança de paradigma vivenciado nas instituições escolares, para que se tornem espaços inclusivos, exige posicionamentos políticos, pedagógicos e institucionais mais democráticos e com respeito diversidade humana. 
12 Travi, M. G. G., Discutir os desafios O fracasso escolar é Relato de OliveiraMenegotto, M.; Santos, G. A. (2009). Revista Psicopedagogia, 26(81), 425-434.

escola um produto de uma experiência sobre complexidade de um rapaz, que na dos fatores, exigindo época

de um olhar amplo e atendimentos tinha

da integrado, a partir 15 anos de idade, de uma interface que estava da contemporânea diante problemas aprendizagem e inclusão, utilizando-se uma vinheta de caso clínico de um e a família. adolescente com representativos problemas de aprendizagem. de entre $o$ trabalho cursando o ensino médio numa escola da rede particular de ensino. discussão é pautada na defesa de um trabalho de cunho interdisciplinar entre

Psicopedagogia, a Psicanálise e a Pedagogia.

13 Barone, L. M. C. Refletir sobre ações Medidas protetoras Artigo teórico de (2013). Reflexões sobre inclusão: Desamparo e compromisso apazes de atender e paternalistas, no orientação às necessidades lugar de orientarem- psicanalítica. especiais de se em direção ao inclusão escolar é indivíduos e grupos, compromisso ético, discutida a partir do conceito reforçam de desamparo dependência, estrutural e do submissão trabalho da cria infantilização. humana para aceder à ordem da cultura.

a medida em que

a parece negar a

a potência

constitutiva

diferença, significando ético. Rev.

Psicopedagogia; 30(93) 212-217. normalizar. Aborda a ascendência do bebê à cultura, a partir de conceitos freudianos.

14 Ribeiro, J. M. L. Relatar a dinâmica Ao escutar os Foi realizado C.,Bastos, A. de grupo de escuta professores (2007). A escuta de professores no trabalho de inclusão escolar de crianças clínica de contribui para o de crianças autistas professores de deslocamento do e psicóticas crianças com discurso pedagógico inseridas em escola transtornos graves tradicional para a por meio de produção de novos reuniões para significados

discussão desses psicóticas e autistas. Estilos da Clínica,15(1), $116-125$ casos com os membros da equipe de atendimento especializado e de reuniões interinstitucionais entre profissionais dessa instituição e da escola, contando com a presença de um psicanalista

15 Fabrício, N. M. Propor C., \& Cantos, P. reflexão sobre a precisa do

O trabalho interdisciplinar é importante, pois possibilita comunhão de diferentes saberes, de modo a respeitar suas diferenças e peculiaridades.

Percebe-se também que a escola, frente à diferença, se vê numa condição de desamparo, necessitando restabelecer o saber do professor, para que ele possa também apostar nas potencialidades do aluno.

Toda e qualquer ação de inclusão deve ter como horizonte a construção do rosto. Construção nascida dos embates entre desamparo estrutural e a Ananké orientará o homem em seu compromisso ético de inventar, com trabalho e pena, seu caminho na história humana

Por não comparecer com mais uma especialidade de saber entre os discursos sobre a criança, $\quad 0$ psicanalista como êxtimo (exterior), concedeu um lugar operatório ao não saber, o que abre espaço para que o impossível de educar em cada caso não leve à impotência $\mathrm{e}$ ao desânimo dos professores, mas funcione como causa de desejo e de trabalho.

de É necessário abordar de a autoestima dos 
V. V. (2011). postura diagnóstica planejado

Diagnóstico-

intervenção-

perspectivas.

Atuação da escola

inclusiva.

Construção

psicopedagógica,

19(19), 112-121.

16 Gusmão, F. A. F., Martins, T. G., \& Luna, S. V. (2011). Inclusão escolar como uma prática cultural: uma análise baseada no conceito de metacontingência. Psic. da Ed., 32, 69-87. escola. de análise como unidade de selecionar em prática cultural. como instrumento replanejado

de trabalho da constantemente,

e como uma escola se organizou para com profissionais para responder às dispostos a rever necessidades paradigmas e com específicas de cada alto grau de aluno. resiliência.

Utilizar o conceito É possível partir da Artigo metacontingência contingências análise do processo comportamentos das sustentado teórico, A educação adquiriu de transformação da que sejam retrospecto

Educação Inclusiva condizentes com o histórico sobre o

princípio inclusivo e behaviorismo

que resultem na aborda documentos aprendizagem. A oficiais sobre a repetição de um inclusão escolar. padrão de

comportamento

reforçado pelas

consequências,

provocam

mudanças culturais.
Rocha, $\mathrm{M}$ L.(2008). Poder e trabalho na escola: práticas inclusivas em discussão. Psicologia Revista, Horizonte, 14(2), 81-94.

Discutir as práticas Há uma tensão entre Artigo teórico, sob de inclusão que as propostas perspectiva das vêm ganhando governamentais de relações de poder corpo entre os inclusão escolar e a de Foucault. professores da rede percepção de pública de ensino a professores sobre partir da análise de suas possibilidades publicações sobre o de atuação nesse tema e das reflexões campo.

nas pesquisas que

vimos realizando

em escolas

municipais de Belo

Horizonte

participantes do

Projeto de

Educação Inclusiva.

18 Freitas, M. C., \& Mendes, E. G. funcional de comportamentos inadequados e inclusão: uma contribuição à formação educadores.

Temas de Implementou e Um avaliou um especial

cuidado Os resultados da programa de educador deve ser de crianças numa intervenção baseado monitorar com creche, gravadas na análise funcional atenção as crianças em do comportamento com necessidades transcritas para proporcionar educacionais analisadas formação para os especiais, porque acordo educadores elas experienciam sistemas solucionarem tais frequentemente categorias,

Psicologia, 16(2), com $261-271$ em problemas, lidando atrasos na aquisição embasaram

comportamentos

desafiadores

exibidos de habilidades na hipóteses sobre as

interação social com causas pares

pela vídeo,

$\mathrm{e}$

de comportamental para

com ambos os

de comportamentos-

alvo quando comparados os momentos pré e pós intervenção. Esta mudança ocorreu de A duas formas: na 
criança, mediando

sua interação com

os colegas e

otimizando sua

escolarização como

um todo intervenção

consistiu

discussões com os educadores sobre os

comportamentos-

problema para

delineamento de

estratégias para

solucioná-los

19 Gomes, Claudia. Caracterizar (2006). Estilos de aprendizagem estilos os A educação para 15 alunos, entre $4^{\circ}$ e inclusão aprendizagem de todos depende das de instituições alunos da rede escolares

responderam

escolar: uma proposta de qualificação regular estadual de especializarem em se questionário. educacional. Rev. Psicopedagogia, 23 (71), $134-44$.

ensino fundamental todos os alunos, o provas

de uma cidade da que vem exigindo estatística

Grande São Paulo.

e descritiva

$$
\begin{aligned}
& \text { atitudes e } \\
& \text { posicionamentos } \\
& \text { que partem, } \\
& \text { fundamentalmente, } \\
& \text { da atualização e } \\
& \text { reestruturação das } \\
& \text { condições atuais da } \\
& \text { maioria das escolas } \\
& \text { brasileiras. }
\end{aligned}
$$

20 Mendes, M. S. Desenvolver estudo A motivação pode Estudo (2013). Da exploratório através exercer uma dupla exploratório quanto inclusão à evasão escolar: o papel da motivação no ensino médio.

Estudos de

Psicologia

(Campinas),

30(2), 261-265

21 Veltrone, A. A., Descrever e analisar É de revisão função, ora como ao objetivo e de bibliográfica sobre causa ora como natureza a relação entre consequência dos bibliográfica. inclusão, motivação processos de Foram citados e evasão no ensino inclusão e evasão artigos

\section{motivação}

percepções estudantes sobre as variadas dimensões do meio escolar. Não foi descrito como a seleção bibliográfica foi realizada. \& Mendes, E. G. as recomendações considerar que e normativos do imp
da
gem (2011). Descrição das propostas do oficiais do apesar da

da porcentagem

Ministério (MEC) identificação

Educação Educação avaliação deficiência da da para identificação alunos da deficiência deficiência

$$
\text { alta MEC }
$$

de avaliação

de deficiência

com intelectual analisados,

intelectual em intelectual sempre é precisa protocolo

intelectual.

Paidéia, 21(50), 413-421. nomenclatura e itens: nome do consequente documento, definição do que descrição e síntese. seja a deficiência $\mathrm{O}$ modelo do intelectual sofreram protocolo de e ainda sofrem análise foi dividido alterações ao longo em três temas: diminuição marcante dos comportamentosproblema da criança e também no comportamento das educadoras,

Os estilos de aprendizagem destoam de muitas práticas educacionais. Os procedimentos educacionais

e parecem interpor-se a todo e qualquer fator externo, inclusive os ambientais.

Os procedimentos de inclusão escolar precisam ser bem planejados estruturados para influenciar positivamente a motivação do estudante.

Políticas de inclusão escolar implica em ampliar o financiamento dos serviços de apoio para um maior contingente de alunos. Pode haver de inflação com alunos com dificuldades menores. Deve-se realizar estudos que analisem a relação entre a legislação e as realidades educacionais para 
da história.

22 Espote,

R., Realizar

uma Tem revisão da literatura avanços na área de nas bases LILACS científica nacional inclusão

PePSIC e SciELO, Scorsolini-

Comin, F. (2013).

de

sobre a inclusão de educacion

surdos: revisão integrativa da literatura

da

científica. PsicoUSF, 18(1), 77-

88.

23 Gesser,

M., Problematizar

a Importância

de São apresentados Nuernberg, A. H., importância de a incluir, nos estudos indicativos sobre a \& Toneli, Maria Juracy Filgueiras. (2012). psicologia social da psicologia deficiência e o considerar a categorias de modo ela se contribuição do modelo social da deficiência à Psicologia \&

$\begin{array}{lr}\text { definição } & \text { da } \\ \text { condição } & \text { da } \\ \text { deficiência } & \\ \text { intelectual, } & \\ \text { avaliação } & \text { da } \\ \text { condição } & \text { da } \\ \text { deficiência } & \\ \text { intelectual } & \text { e } \\ \text { atendimento } & \\ \text { educacional. } \\ \text { A partir de buscas } \\ \text { nas bases LILACS, } \\ \text { PePSIC e SciELO, } \\ \text { entre 2005 e 2011, } \\ \text { foram recuperados } \\ \text { e analisados na } \\ \text { íntegra sete artigos. } \\ \text { a }\end{array}$

deficiência como análise como as de articula com uma categoria de gênero, raça, categorias de análise a ser geração e classe análise como as de estudada na social. gênero, raça, psicologia social. Sociedade, 24(3), 557-566. pesquisa e na atuação profissional do psicólogo

geração e classe social. Em seguida, aborda o modelo social da deficiência. Por fim, defende-se a relevância de a psicologia social crítica integrar ao seu marco teórico os estudos sobre deficiência.

24 Benevides, P. S. Dissolver as figuras As tendências Artigo teórico que (2011). As retóricas que discursivas da relaciona a retóricas contemporâneas e a significação da educação inclusiva.

Psicologia \&

$\&$ empreendimentos

Sociedade, 23(2), pedagógicos. 248-253. verificar as consequências pragmáticas desta indefinição legal na avaliação dos alunos com deficiência intelectual.$$
\text { (1) }
$$

A inclusão ocorre de forma ineficaz $\mathrm{e}$ diferentemente do proposto na política de educação inclusiva, um dos principais fatores a esse respeito é a falta de preparo dos professores.

Acredita-se que, por meio da consideração do modelo social de deficiência, seja possível romper com a hegemonia do modelo biomédico da deficiência.
Necessidade de uma investigação que incida sobre $\mathrm{O}$ funcionamento dos discursos que advogam pela educação inclusiva. As figuras retóricas devem evidenciar que os dispositivos de exclusão e normalização encontram-se presentes em uma quantidade bem menor na literatura do que poderíamos 
25 Camargo, S. P. Revisar H., \& Bosa, Cleonice Alves. (2009).

Competência social, inclusão escolar e autismo: revisão crítica da literatura.

Psicologia Sociedade, 21(1), 65-74.

26 Gomes, C., \& Compreender Souza, V. L. T. relações (2012).

Psicologia e inclusão escolar: reflexões sobre o processo de subjetivação de professores.

Psicologia:

Ciência

Profissão, 32(3), 588-603..

\section{subjetivação}

professores

processo inclusão escolar$$
\text { as Considerar o Observações, }
$$$$
\text { de professor inclusivo sistemas }
$$$$
\text { de como um sujeito, é conversacionais e }
$$$$
\text { no uma condição entrevistas de }
$$$$
\text { de impulsionada dentro aprofundamento. }
$$
de um tecido social As informações em que se fundem a acessadas foram subjetividade social organizadas em e a individual em três eixos de dimensões análise: 1) processuais dotadas necessidade / de sentido para o impossibilidade de sujeito, que, dessa atividades perspectiva, é autor pedagógicas de suas ações e diferenciadas, representações.

supor à primeira vista.

de Indicação da sem necessidade de do outros estudos sobre crianças autistas préescolares, focalizando a intensidade e frequência de certos comportamentos.

Os núcleos de significação na vivência da proposta inclusiva se sustentam por alguns elementos comuns, que têm sua origem no clima organizacional.

) Promover a inclusão escolar é planejar ações de formação e de atuação que insiram seus profissionais em novas esferas de compreensão e de vivência da proposta inclusiva, nas quais possam questionar, discordar, elaborar e criar ações de enfrentamento do cotidiano.

27 Silva, C. L., \& Investigar o papel A constituição de Estudo de caso/ Leme, M. I. S. do diretor escolar um ambiente Realizada análise (2009). O papel do diretor escolar na implantação de uma cultura educacional inclusiva.

Psicologia:

Ciência na constituição de propício à inclusão documental uma cultura escolar escolar depende de realizada inclusiva uma construção entrevista. coletiva, na qual o utilizada como diretor escolar método a análise exercerá um papel de conteúdo de decisivo.

Bardin.

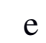
A democratização da gestão e a educação inclusiva se encontram

estreitamente relacionadas, o que sugere que uma escola inclusiva é, antes de tudo, uma escola democrática. O psicólogo educacional devem considerar a realidade educacional como maior que um fenômeno puramente psicológico. psicologia escolar e psicológicas são aborda a relação educacional no base para entre a produção da processo de paradigmas exclusão escolar e consolidação de um educacionais, sendo social, o papel e discurso que as investigações formação democratizante da em psicologia são psicólogo escolar e educação brasileira fundamentais para a a inclusão escolar. compreensão dos . 
362-375.

processos

educacionais

escolares.

29 Sekkel, M. C.,

Identificar

os A maior dificuldade Etnografia

Brandão, Suely

determinantes para diante

da realizada

numa

de Barros. (2010).

Uma questão para

a educacão

inclusiva: expor-

se ou resguardar-

se? Psicologia:

Ciência

a construção de deficiência é expor- escola de educação

ambientes

se a si mesmo. Os infantil,

com

inclusivos a partir processos inclusivos observação de

da experiência de podem se fortalecer crianças de 4 a 6

inclusão de crianças com a criação de anos; levantamento

com deficiência

condições atrativas da documentação

ao expor-se e uma pedagógica

cultura de respeito entrevistas com

Profissão, 30(2),

296-307.

ao resguardar-se, profissionais e

considerando alunos. Teoria

sempre os limites da crítica da sociedade relação com o outro como abordagem

e cuidando para que teórica.

Os

os sujeitos conteúdos das

participem das entrevistas e

decisões observações a

institucionais que partir do

lhes dizem respeito movimento de

expor-se ou de

resguardar-se

30 Anache, A. A., \& Realizar um A pessoa com Foram pesquisadas Mitjáns, A. M. levantamento das deficiência mental 38 dissertações e (2007).

Deficiência pesquisas sobre a quem tem causado 84 teses no período mental produção científica na base de dados da CAPES: o lugar da aprendizagem.

Psicologia

deficiência mental e maiores

de 1990 até

e a partir dessa dificuldades

à 2005/2006, caracterização, prática cotidiana registradas no compreender o dos professores nas banco de teses da lugar que nela escolas ocupam as pesquisas

Escolar processo ao

Educacional, aprendizagem da

11(2), 253-274. população com

deficiência mental

Capes, sobre deficiência mental. Da análise de conteúdo dos resumos foram obtidas

informações sobre a data, o locus das pesquisas, o tema tratado e o direcionamento teórico e metodológico.

31 Tada, I. N. C., Realizar Lima, V. A. A.; levantamento Melo, T. G., \& estatístico Correio, D. Y. V.

$\mathrm{T}$. descritivo Professores sentem- Pesquisa realizada se despreparados em 22 escolas de para lidar com o Porto Conhecendo o processo de inclusão escolar rede pública

sobre processo de Velho/Rondônia, em Porto Velho RO. Psicologia: Teoria e Pesquisa, 28(1), 65-69. e as com profissionais escolarizar o aluno se diários de com deficiência em campo e análise decorrência de um documental. Foram longo processo registradas as histórico-cultural de adequações exclusão. arquitetônica de acessibilidade e a

Para a escola se tornar um ambiente inclusivo,

necessário identificar e procurar reduzir os fatores que provocam o sentimento de ameaça e, ao mesmo tempo, incentivar o diálogo entre os pares e a construção da memória institucional, de modo a fortalecer o sentimento de pertencimento e o de autoria

Necessidade de realização de estudos sobre os processos de aprendizagem de pessoas com deficiência mental, sobretudo daquelas consideradas mais comprometidas.

Necessidade de aprimoramento dos bancos e das bases de dados

As categorias discutidas revelam que as escolas, de maneira geral, não estão adaptadas para receber o aluno com deficiência, apresentando barreiras arquitetônicas. As salas de recursos apresentam-se com poucos materiais Há ainda a falta de 
presença de sala de recursos. Analisouse documentos da rede de ensino e da escola. Realizouse levantamento estatístico descritivo do tipo de deficiência, alunos incluídos por série escolar e estrutura física das escolas.

32 Lourenç,

E., Investigar

as Considera-se que o A seleção dos Miranda, C. S. relações entre a periódico em estudo artigos de interesse H., \& Póvoa, J. Psicologia e a representa M. (2012). educação inclusiva tendências as da pesquisa, foi Psicologia educação inclusiva Brasil perspectiva e no Brasil a partir periódico

de feita considerando periódico no Psicologia: Ciência na e Profissão.

Psicologia:

Ciência Profissão.

Psicologia: Ciência

Profissão, 32, 206-215. do atuação prática e de título, resumo e pesquisa dos palavras-chave dos psicólogos artigos publicados
brasileiros, de em todos os maneira geral e, números do especialmente, no periódico. Cada que concerne a sua artigo selecionado atuação e às suas foi analisado em investigações em relação aos relação à educação seguintes itens: inclusiva. autoria, características do relato, uso de referências temática.

conhecimento sobre o diagnóstico da deficiência de alguns alunos incluídos, e a defasagem

idade/série sobre o diagnóstico da deficiência de alguns alunos incluídos, e a defasagem idade/série.

Os resultados revelaram que os artigos se dividem quase igualmente entre teóricos e práticos; os autores são em maioria afiliados a instituições públicas e que a Psicologia Social é o principal referencial.

número de artigos sobre as relações entre Psicologia e educação inclusiva vem aumentando e para uma visão mais realista do tema, é necessário recorrer a fontes complementares.

\subsubsection{Análise e discussão da primeira categoria de publicações.}

Esta seção apresenta os resultados das análises referentes à primeira categoria desta revisão de literatura. Nela foram classificados artigos que discutem, prioritariamente, aspectos teórico-conceituais da inclusão escolar. Esses resultados estão apresentados na seguinte ordem: em primeiro lugar, são apresentados aspectos gerais tratados pelos textos acerca da inclusão escolar, seguido de uma apresentação desses textos, em função das revistas em que foram publicados. 
Na sequência, apresenta-se a relação entre inclusão escolar e Educação Especial, as definições da inclusão escolar presentes nos artigos e os marcos políticos mais comumente utilizados para contextualização do tema da inclusão escolar. Além disso, são apresentadas as principais abordagens teóricas presentes nos artigos classificados nessa categoria, os diagnósticos citados nos textos e as questões referentes à atuação dos profissionais da escola e à inclusão escolar. Outro tópico abordado refere-se à relação entre desenvolvimento humano e inclusão escolar, às modalidades e etapas de ensino em que as pesquisas foram realizadas; além de pontuar quais são as dificuldades e as alternativas encontradas no processo de inclusão escolar e, por fim, apresenta-se a conclusão desta seção em face do tema em estudo nesta pesquisa.

A maioria das publicações acessadas está nessa primeira categoria e, como já afirmado anteriormente, nela se desenvolve discussões que possuem vários aspectos relacionados à inclusão escolar, como: o âmbito jurídico e o discurso científico acerca da inclusão escolar, em face da subjetividade dos indivíduos; a constituição dessa subjetividade em situação de inclusão escolar e o desenvolvimento humano; a história da educação especial e da definição do conceito de inclusão social e escolar; a escola e a diversidade humana; o papel da psicologia na educação inclusiva; a evasão e a inclusão escolar; o diagnóstico e a atuação educacional frente à deficiência.

Cinco artigos são provenientes de revistas com orientação psicanalítica: Voltolini (2004), Bernardino (2007), Ribeiro e Bastos (2007), Stellin, Martins, Triandopolis e Costa (2009) e Prioste (2010). Além da temática da inclusão escolar, três desses trabalhos têm em comum o fato de ressaltarem a questão da constituição subjetiva dos alunos em situação de inclusão escolar (Voltolini, 2004; Bernardino, 2007; Stellin, Martins, Triandopolis, \& Costa, 2009). Os outros dois artigos coincidem ao trazerem reflexões sobre intervenções com 
orientação psicanalista, que foram realizadas junto a professores que lidam com crianças em situação de inclusão escolar.

Dois trabalhos, de temáticas bastante diversas, foram publicados em uma revista que trata particularmente da relação entre psicologia e educação: Benedetti e Urt (2008), que discute o cenário contemporâneo de desenvolvimento infantil e problematiza o papel da escola a esse respeito, em interface com o diagnóstico de TDAH e Gusmão, Martins e Luna (2011), que relaciona o conceito de metacontingência e a educação inclusiva. Um artigo foi publicado em revista que publica sobre educação, gênero e raça, Nabuco (2010), tratando das contradições das políticas educativas e suas institucionalizações, sob um referencial psicanalítico lacaniano.

Três artigos desenvolvem uma análise histórica a respeito das concepções sobre as necessidades educacionais especiais: Areosa (2007), que apresentou o percurso histórico da categorização dos portadores de necessidades educacionais especiais; Zucoloto (2007), que investigou a história das dificuldades de escolarização das crianças de classes populares; Nicolino e Zanotto (2010) que realizaram uma revisão sobre análise do comportamento, educação especial e inclusão. Cinco trabalhos, provenientes de uma revista de psicopedagogia, tratam o tema da inclusão escolar a partir de diferentes aspectos: refere-se aos estilos de aprendizagem e à diversidade de alunos (Gomes, 2006); trata dos desafios da escola e dos problemas de aprendizagem e inclusão (Travi, Oliveira-Menegotto \& Santos, 2009); refere-se à atuação da psicologia escolar na prática da educação inclusiva (Gomes \& Souza, 2011); realiza a reflexão a respeito da postura diagnóstica como instrumento de trabalho da escola (Fabrício \& Cantos, 2011); trata das ações capazes de atender às necessidades de indivíduos e grupos em situação de inclusão escolar, a partir de uma perspectiva psicanalítica (Barone, 2013). 
Três artigos focam aspectos sociais da inclusão: a defesa da deficiência como categoria de análise para o psicólogo escolar (Gesser, Nuernberg \& Toneli, 2012); a análise de figuras retóricas e de dispositivos de exclusão nos empreendimentos pedagógicos (Benevides, 2011); as competências sociais no autismo (Camargo \& Bosa, 2009). Seis artigos dessa categoria desenvolvem revisões de literatura: sobre inclusão escolar e social (Roriz, Amorim \& Rossetti-Ferreira, 2005); sobre as concepções dos processos de aprendizagem da população com deficiência intelectual (Anache \& Mitjáns, 2007); sobre carências e desafios da psicologia na atuação da educação inclusiva (Gomes \& Souza, 2011); sobre a relação entre psicologia e a educação inclusiva no periódico Psicologia Ciência e Profissão (Lorenço, Miranda \& Póvoa, 2012); sobre a relação entre inclusão, motivação e evasão escolar no Ensino Médio (Mendes, 2013); sobre a inclusão educacional de surdos (Espote, Serralha \& Scorsolini-Comin, 2013).

A análise desses trabalhos de revisão de literatura ilustra a amplidão com que o tema da inclusão escolar é abordado na literatura. Podem-se notar iniciativas de definição teórica do tema como uma necessidade recorrente, talvez pela mudança paradigmática que ela pressupõe. Essa constatação pode ter relação com outra, que é a da preocupação dos autores em relacionar essa questão a uma área de estudo em particular, no caso a psicologia. Uma terceira preocupação observada nas revisões de literatura, presentes nesta categoria, é a de definir como se dá o processo de inclusão para grupos específicos, justamente por conta de suas peculiaridades, como o caso do estudo de Espote, Serralha e Scorsolini-Comin (2013) dedicado à inclusão escolar dos surdos, por exemplo. A quarta constatação possível a respeito dos trabalhos de revisão bibliográfica, já num contexto da inclusão escolar vista no sentido mais amplo e não somente relacionado à deficiência, é a de aspectos subjetivos dos alunos, afirmando que as premissas da inclusão escolar causem um impacto positivo nesses alunos, aumentando o tempo de sua permanência na escola. Como afirmado, essas constatações que 
foram relacionadas denotam uma busca de alcançar um consenso estável em volta do paradigma da educação inclusiva (Kuhn, 1992).

Tratando-se de uma categoria que aborda a questão teórica-conceitual da inclusão escolar, a maioria dos artigos, em algum momento, dedicou-se ao corpo do texto, a definir qual o conceito de inclusão estava sendo considerado e, nesse sentido, podem ser observadas algumas tendências. Uma delas é a que trata a inclusão escolar dentro de um espectro mais amplo, no sentido de inclusão social, oriunda das discussões sobre direitos humanos (Roriz, 2005; Areosa, 2007; Stellin et al., 2009; Prioste, 2010; Gusmão, Martins \& Luna, 2011; Barone, 2013; Mendes, 2013). Uma segunda tendência diz respeito à relação entre a diversidade humana e o fracasso escolar (Zucoloto, 2007; Benedetti \& Urt, 2008; Melo \& Rocha, 2008; Freitas \& Mendes, 2008; Facci, 2010; Fabrício \& Cantos, 2011; Veltrone \& Mendes, 2011).

Alguns textos dedicaram-se à relação entre Educação Especial e Educação Inclusiva, como, por exemplo, Nabuco (2010), em que a autora argumenta que a educação inclusiva e a educação especial são construídas a partir de paradigmas opostos, sendo que a primeira repousa "sobre noções de deficiência e de inadaptação e também sobre instituições e públicos específicos" (Nabuco, 2010, p.67). Já a educação inclusiva implica a "igualdade de oportunidades para todos e o acesso a um direito universal, sendo que o atendimento especializado é destinado a pôr em evidência a singularidade do sujeito" (Nabuco, 2010, p. 67). Ainda tratando da definição da inclusão, outros textos a tomam como inverso da exclusão (Voltolini, 2004); há aquele que entende a inclusão como processo constitutivo de subjetividade (Bernardino, 2007), além de quem a compreenda como construção histórica de discursos sociais que influenciam a visão que o sujeito tem de si e do mundo (Stellin et al., 2009). 
Há dois marcos políticos que predominam para contextualizar o tema da maioria dos artigos: A Declaração de Salamanca (1994) e a Lei de Diretrizes e Bases da Educação (Brasil, 1996). Esses são marcos políticos que instituem a perspectiva da educação inclusiva, suplantando os entendimentos anteriores de segregação e integração.

As publicações dessa categoria apresentam diferentes modelos de abordagem teórica, sendo as mais recorrentes aquelas ligadas à psicanálise, à perspectiva histórico-cultural, à análise de contingências e as inspiradas em Focault. A psicanálise é considerada em trabalhos que abordam as condições subjetivas dos alunos em situação de inclusão escolar, a presença da lógica da exclusão na estrutura social e nos discursos historicamente construídos e sexualidade (Voltolini, 2004; Bernardino, 2007; Ribeiro \& Bastos, 2007; Stellin, et al., 2009; Prioste, 2010). Sob a perspectiva histórico-cultural, Facci e Dias (2010) argumentaram acerca da importância da escola no desenvolvimento psicológico dos alunos. Sobre a relação entre análise do comportamento e a inclusão escolar, Nicolino e Zanotto (2010) apresentam uma revisão bibliográfica. Com inspiração em Foucault, Melo \& Rocha (2008) discutiram práticas de inclusão em escolas municipais; Benevides (2011) trabalhou com as tendências discursivas da educação inclusiva e Espote (2013) revisou a literatura sobre inclusão de surdos.

Anteriormente, foi mencionada a coexistência de artigos de tratam da inclusão de forma mais geral e outros que delimitam seu foco à inclusão escolar. Dentre esses últimos, há ainda aqueles que delimitaram um diagnóstico específico como seu objeto de estudo, sendo eles o Transtorno do Déficit de Atenção e Hiperatividade (TDAH), a Deficiência Auditiva, a Síndrome de Down, os Transtornos Globais do Desenvolvimento e Autismo e a Deficiência Intelectual. Em relação ao TDAH, Benedetti e Urt (2008) abordaram a dificuldade da escola em lidar com a diversidade de alunos e Eidt e Tuleski (2010) discutiram a respeito do TDAH como uma expressão das contradições da sociedade atual. Sobre Deficiência Auditiva, Espote et al. (2013) realizaram uma revisão de literatura sobre como ocorre o processo de inclusão 
escolar de surdos. Prioste (2010) propôs uma reflexão sobre a sexualidade de um estudante com Síndrome de Down. Em relação ao autismo, Roriz et al. (2005) fizeram uma revisão de literatura para verificar a abordagem com que o tema Autismo é abordado em interface com a inclusão escolar na literatura mundial; Ribeiro e Bastos (2007) relataram uma dinâmica de grupo com professores de crianças Autistas e Psicóticas; e Camargo e Bossa (2009) fizeram uma revisão sobre o conceito de competência social na área de Autismo e inclusão escolar. Veltrone e Mendes (2011) analisaram documentos com recomendações oficiais do Ministério da Educação para a identificação de alunos com Deficiência Intelectual. Ainda a respeito da Deficiência Intelectual, Anache e Mitjáns (2007) fizeram um levantamento acerca das pesquisas sobre deficiência intelectual e o processo de aprendizagem.

Foi observado que alguns trabalhos se remetem à inclusão escolar de pessoas com deficiências, apesar de não delimitarem um diagnóstico específico no corpo do texto. Essa constatação pode ser interpretada de duas formas. A primeira delas diz respeito à possibilidade de priorização de reflexões conceituais que são comuns a qualquer diagnóstico, ou referindo-se a aspectos da inclusão escolar que dizem respeito à classificação diagnóstica apenas de forma tangencial. Por outro lado e de forma relacionada, essa mesma constatação pode significar uma desconsideração das particularidades do desenvolvimento, das implicações educacionais e psicológicas específicas de cada diagnóstico. Na hipótese de melhor definição a respeito dessas hipóteses, é reconhecida a necessidade de análises mais aprofundadas.

Como poderá ser visto adiante, a quarta categoria dessa revisão trata da formação profissional e a inclusão escolar, mas, a despeito disso, alguns trabalhos que abordaram a atuação profissional de forma tangencial encaixaram-se melhor nessa primeira categoria, pois se referem a questões que tratam da atuação de diferentes profissionais no contexto de inclusão escolar. Gomes e Souza (2012), por exemplo, analisam a subjetividade do professor 
e Silva e Leme (2009) o papel do diretor escolar na inclusão escolar. É abordado também o papel do psicólogo e da psicologia escolar (Dazzani, 2010) em interface com o tema da inclusão escolar. O consenso desses artigos é a relevância da atuação dos profissionais da escola para o sucesso da inclusão escolar.

Em relação ao desenvolvimento psicológico humano e inclusão escolar, pode-se observar que os autores abordaram: a importância da escola no desenvolvimento psicológico (Facci, 2010); a necessidade de focalizar aspectos subjetivos constituintes do sujeito beneficiário da inclusão escolar (Voltolini, 2004; Bernardino, 2007; Stellin et al., 2009); a motivação (Mendes, 2013), a sexualidade (Prioste, 2010), a relevância do chamado perfil do ambiente escolar e suas práticas para a promoção da inclusão nesse ambiente (Sekkel et al., 2010).

Nesta revisão, foram encontrados dez artigos de pesquisas empíricas realizadas em ambiente escolar (Gomes, 2006; Ribeiro \& Batos, 2007; Benedetti \& Urt, 2008; Freitas \& Mendes, 2008; Silva \& Leme, 2009; Travi, Oliveira-Menegotto \& Santos, 2009; Prioste, 2010; Sekkel, Zanelatto \& Brandão, 2010; Gomes \& Souza, 2012; Tada, 2012). Todos os estudos foram realizados em escola regular. Quatro desses trabalhos foram realizados em escolas públicas (Gomes, 2006; Silva \& Leme, 2009; Travi, Oliveira-Menegotto \& Santos, 2009; Prioste, 2010 e Sekkel, Zanelatto \& Brandão, 2010). Um trabalho foi realizado tanto em escolas públicas quanto privadas (Tada, 2012).

Em relação à etapa de ensino, quatro trabalhos foram realizados em creche ou Educação Infantil (Ribeiro \& Batos, 2007; Freitas \& Mendes, 2008; Skkel, Zanelatto \& Brandão, 2010; Gomes e Souza, 2012), sendo que dois deles envolveram tanto a Educação Infantil quanto o Ensino Fundamental. Cinco artigos focaram exclusivamente o Ensino Fundamental (Gomes, 2006; Ribeiro \& Batos, 2007; Benedetti \& Urt, 2008; Silva \& Leme, 2009; Prioste, 2010); um trabalho foi desenvolvido no Ensino Médio (Travi, Oliveira- 
Menegotto \& Santos, 2009); um envolveu Ensino Fundamental e Médio (Tada, 2012); um artigo foi realizado no contexto do Ensino Superior (Benedetti \& Urt, 2008).

A análise dos artigos dessa categoria aponta para a existência de dificuldades abarcando, por exemplo, a distância entre a lei, atualmente vigente no país, e o pensamento de quem executa a inclusão escolar (Benevides, 2011; Espote, 2013); a tendência à técnica, o que faz com que a escola arregimente diversos profissionais externos a ela para fornecer auxílio na solução dos problemas de aprendizagem (Souza, 2012); e o despreparo do professor para a inclusão escolar (Gomes, 2012). Essas dificuldades são parecidas com as apontadas em estudos internacionais a respeito da inclusão escolar, como o de Kovacevic \& Dragana (2012), que relata a experiência da Sérvia com o tema e no qual o autor revela que crianças com necessidades especiais estão integradas em escola regular, mas, em função da ainda inadequada preparação das escolas regulares, as crianças são submetidas a numerosos problemas educacionais.

Por outro lado, vários autores apontam diferentes alternativas para ultrapassar tais dificuldades. Podemos dizer que temos grandes categorias de alternativas, que se relacionam entre si. A primeira diz respeito à atuação profissional e defende a necessidade de uma formação profissional interdisciplinar que permita uma prática com base no diálogo entre diferentes profissionais. Esse diálogo fundamentaria, por sua vez, a ética da inclusão. A segunda categoria de alternativas diz respeito à importância de estudos focados na discussão sobre a inclusão e na elaboração de propostas pró-inclusão. A terceira categoria diz respeito à necessidade de novas pesquisas sobre o desenvolvimento atípico, sobretudo aquele que promovem maiores comprometimentos. A quarta categoria de propostas alternativas diz respeito às relações entre políticas públicas e as ações institucionais.

Nenhum artigo, classificado nessa categoria, tratou do ensino e aprendizagem da matemática ou sobre a paralisia cerebral. Diante desses entendimentos, pode-se concluir que o 
conceito de inclusão é discutido de forma bastante ampla, perpassando desde a inclusão social de uma forma geral até a inclusão escolar, em específico. Neste último âmbito, também se observa a amplitude do debate, à medida que ele se estende desde ao fracasso escolar, de uma forma geral, até a escolarização de pessoas com necessidades educacionais especiais especificamente. Assim, nesta conclusão, acompanha-se o entendimento de Roriz (2005, p. 3) de que a "separação entre inclusão social e escolar se trata de uma separação artificial, já que não há como cindir as duas, ambas fazendo parte de um mesmo processo social". $\mathrm{Na}$ sequência, apresenta-se a segunda categoria de artigos dessa revisão bibliográfica. 


\subsubsection{A segunda categoria: artigos que se referem às concepções sobre inclusão.}

Contando com vinte e cinco artigos, a segunda categoria trata de publicações que se debruçaram sobre as concepções que as pessoas têm a respeito da inclusão escolar, especialmente professores, pais e os próprios estudantes. Os trabalhos, agrupados nessa segunda categoria, estão apresentados na Tabela 2.

Tabela 2

Artigos que se referem às concepções sobre a inclusão

\begin{tabular}{|c|c|c|c|c|c|}
\hline & Referência & Objetivos & Tese & Método & Resultados \\
\hline 1 & $\begin{array}{l}\text { Rahme, M. M. } \\
\text { F. (2010). } \\
\text { Movimentos } \\
\text { transitivistas } \\
\text { em um } \\
\text { contexto de } \\
\text { inclusão: uma } \\
\text { transmissão } \\
\text { entre pares. } \\
\text { Estilos da } \\
\text { Clínica, } 15 \text { (1), } \\
\text { 26-39. }\end{array}$ & $\begin{array}{l}\text { Discutir } \\
\text { questões } \\
\text { referentes à } \\
\text { transmissão } \\
\text { simbólica que } \\
\text { pode ocorrer } \\
\text { entre crianças } \\
\text { na escola, } \\
\text { quando } \\
\text { algumas delas } \\
\text { percebem que } \\
\text { um colega não } \\
\text { consegue } \\
\text { expressar } \\
\text { como os } \\
\text { outros suas } \\
\text { necessidades } \\
\text { ou não se } \\
\text { insere do } \\
\text { mesmo modo } \\
\text { que os outros } \\
\text { no dispositivo } \\
\text { escolar. }\end{array}$ & $\begin{array}{l}\text { Trata-se da defesa } \\
\text { de que o } \\
\text { transitivismo, } \\
\text { conceito } \\
\text { psicanalítico, pode } \\
\text { contribuir para a } \\
\text { discussão de uma } \\
\text { possível } \\
\text { transmissão } \\
\text { simbólica entre } \\
\text { pares na escola. }\end{array}$ & $\begin{array}{l}\text { Foi realizado um } \\
\text { relato de caso de } \\
\text { um estudante } \\
\text { com transtorno } \\
\text { invasivo do } \\
\text { desenvolvimento } \\
\text {, em sua relação } \\
\text { com os colegas } \\
\text { de classe, a } \\
\text { partir do } \\
\text { conceito } \\
\text { psicanalítico de } \\
\text { transitivismo. }\end{array}$ & $\begin{array}{lr}\text { O percurso do } \\
\text { participante na } \\
\text { escola parece ter- } \\
\text { lhe possibilitado } \\
\text { maior } \\
\text { organização } \\
\text { subjetiva, o que } \\
\text { pode } \\
\text { observado a partir } \\
\text { dos próprios } \\
\text { movimentos } \\
\text { transitivistas que } \\
\text { ele passa a } \\
\text { realizar a } \\
\text { direção em } \\
\text { colegas de escola. }\end{array}$ \\
\hline 2 & $\begin{array}{l}\text { Rodrigues, I. } \\
\text { B., Moreira, L. } \\
\text { E. V., \& } \\
\text { Lerner, R. } \\
\text { (2012). } \\
\text { Análise } \\
\text { institucional do } \\
\text { discurso de } \\
\text { professores de } \\
\text { alunos } \\
\text { diagnosticados } \\
\text { como autistas } \\
\text { em inclusão } \\
\text { escolar. }\end{array}$ & $\begin{array}{l}\text { Compreender } \\
\text { quais são as } \\
\text { concepções } \\
\text { dos } \\
\text { professores da } \\
\text { rede pública } \\
\text { sobre } \quad \text { os } \\
\text { alunos } \\
\text { diagnosticados } \\
\text { como } \\
\text { portadores de } \\
\text { TGD ou } \\
\text { autismo no } \\
\text { ensino regular }\end{array}$ & $\begin{array}{l}\text { As concepções dos } \\
\text { professores sobre a } \\
\text { inclusão estão na } \\
\text { base das posições } \\
\text { assumidas no } \\
\text { cotidiano escolar. }\end{array}$ & $\begin{array}{l}\text { Foram realizadas } \\
\text { entrevistas } \\
\text { individuais com } \\
\text { seis professoras } \\
\text { da rede pública e } \\
\text { analisadas com } \\
\text { base } \\
\text { referencial no } \\
\text { teórico } \\
\text { análise da } \\
\text { institucional do } \\
\text { discurso. }\end{array}$ & $\begin{array}{l}\text { As professoras } \\
\text { pautam seu } \\
\text { trabalho por } \\
\text { aquilo que é } \\
\text { ditado pelo } \\
\text { currículo básico. } \\
\text { Há entendimento } \\
\text { sobre a } \\
\text { necessidade de } \\
\text { trabalho } \\
\text { diferenciado e } \\
\text { individualizado } \\
\text { para os estudantes } \\
\text { inclusos. }\end{array}$ \\
\hline
\end{tabular}




$\begin{array}{ll}\text { Psicologia: } & \text { e que posições } \\ \text { teoria } e & \text { assumem } \\ \text { prática, 14(1), } & \text { perante os } \\ 70-83 . & \text { alunos com } \\ & \text { base em tais } \\ & \text { concepções. }\end{array}$
(2009). Escolarização e preconceito: lembranças de jovens com e sem deficiência. . Psicologia

Escolar

Educacional, 13(2), 243250. sem trajetória escolar
Ohl, N. G., Apresenta o A escola é um Entrevista

Angelucci, C. resultado de espaço onde ocorre semidirigida, da B., Nicolau, A. pesquisa sobre o processo de qual

M., Honda, C. narrativas de socialização e é participaram três jovens com e necessária uma depoentes com deficiência que ela possa dois sem sobre sua melhor atender às deficiência, necessidades
educacionais especiais entre 18 e 22 anos de idade, alunos, de forma a sexos, os garantir que o estudam processo de estudaram socialização ocorra escolas da melhor forma inclusivas possível

e e

Not

também

também, a

presença de experiências de preconceito em ambiente escolar m e necessidade de preparo dos professores e modificação na estrutura da escola

Vitta, F. C. F. Verificar as Faltam estudos Entrevistadas $\begin{array}{lll}(2010) & \text { A concepções } \\ \text { inclusão } & \text { da das }\end{array}$ Faltam estudos que permitem sete berçaristas avaliar as atuais da Secretaria

Os resultados inclusão da das criança com profissionais necessidades do berçário condições da especiais na relativas à Educação

da
de inserção da criança deficiente dados, berçaristas. criança com no berçário.

Cadernos de necessidades Pesquisa, especiais na 40(139), 75- rotina de 93. atividades desenvolvidas

\section{organizados}

Artioli, A. L. Propor uma Ainda que 68 professores (2006). atualmente exista Municipal Educação

segundo

categorias

analíticas:

conceitos

relativos

processo

inclusão,

benefícios para a

criança

diferenças entre

as crianças nessa

faixa etária,

foram

submetidos

análise

qualitativa.

à

mostraram que a

inclusão de

crianças com

de necessidades

Os especiais é vista

com reservas,

explicitando

ideias

preconcebidas

sobre

deficiência. Eles

ao se justificam pela de

conhecimento do desenvolvimento

infantil e dos

fatores que $o$

envolvem, bem

como pelo fato de os profissionais

vincularem suas atividades às experiências pessoais.

A formação docente e a 


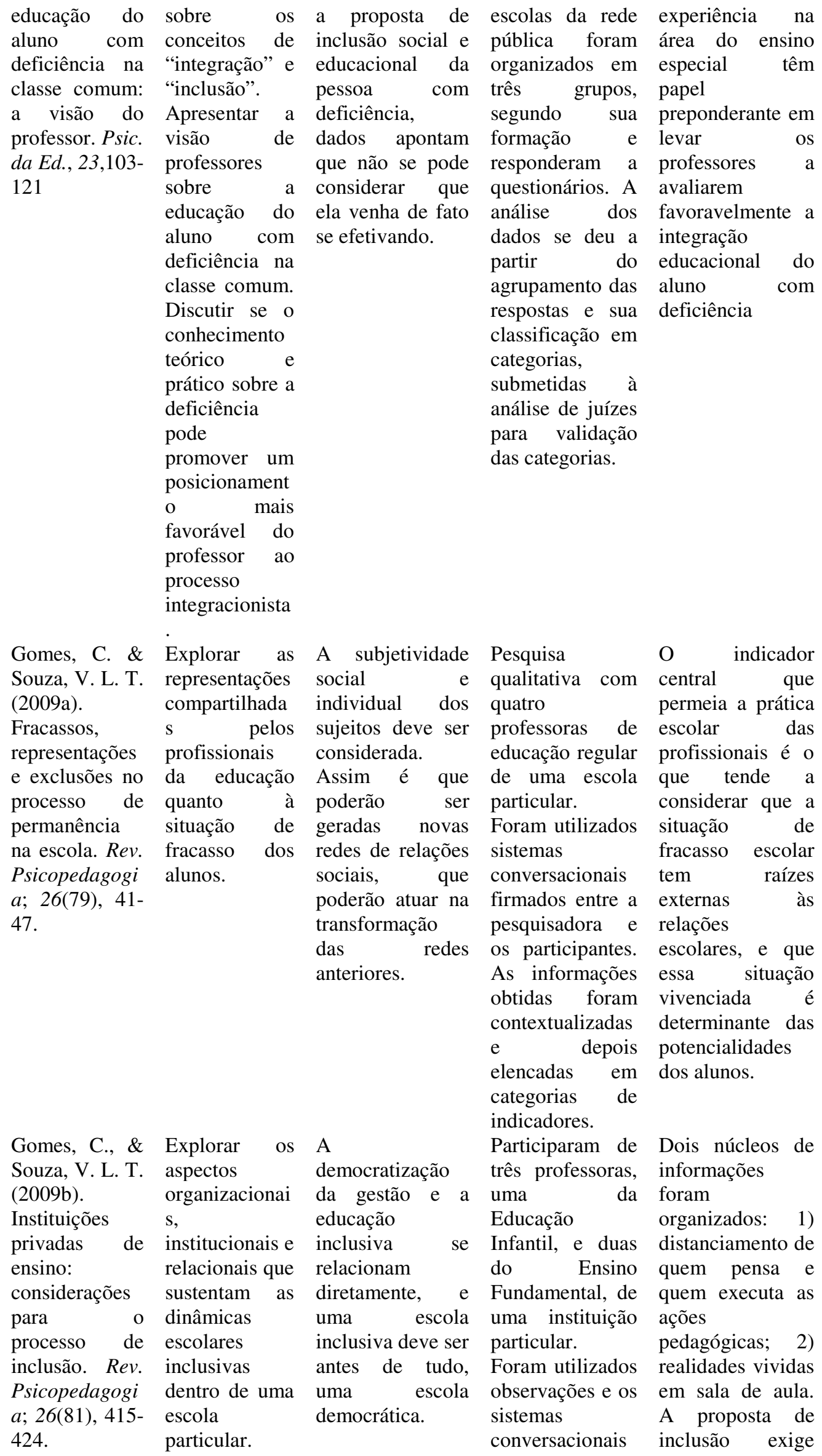


Cintra, G. M. Avaliar

S., Rodrigues, expectativas

S. D., \& de diferentes

Ciasca, S. M. grupos

(2009).

Inclusão

escolar:

coesão

há

nas

expectativas de

pais

professores?

professores,

Rev.

e pais de alunos

Psicopedagogi $a$, 26(79), 55-

64.

com

necessidades

educativas

especiais

(NEE) e pais

de alunos

cujos filhos

estão

matriculados

em classe

onde há

crianças com

NEE. realizados

mantidos

instituição.

e uma nova cultura

na

que possibilite

espaços

democráticos e

criativos com

enfoque na

compreensão e

respeito às

diversidades.

as É importante que a escola abra espaço para ouvir os principais indivíduos que

Rocha, M. A. Verificar a As crenças M., Cabussú, crença dos determinam a

M. A. S. T., educadores e conduta e prática

Soares, V. G., pais sobre a pedagógica dos

\& Lucena, R. inclusão

(2009).

escolar

educadores, a

Dislexia: alunos o sentimento dos

atitudes de disléxicos; alunos disléxicos

inclusão. Rev. bem como

Psicopedagogi suas atitudes

$a, 26(80), 242-$ em relação a

53. essa inclusão e

como esses

alunos se

sentem no

ambiente

escolar.
Fizeram parte do Houve

estudo 16 pais e divergências nas

4 professores. expectativas entre

Dentre os pais, os indivíduos

quatro tinham ouvidos.

filhos com NEE. Enquanto os

As crianças

estavam

professores

priorizam $\quad 0$

matriculadas no aspecto

ensino infantil e emocional e

na $1^{\text {a }}$ série do social da

ensino

inclusão, os pais

fundamental. A demonstraram

avaliação das que esperam que

expectativas dos se priorize e se

participantes se atente para os deu por meio de aspectos

questionário emocional, social

semiestruturado. e pedagógico.

A análise dos dados foi feita de forma

qualitativa

Aplicação de Há discrepância questionários à entre as crenças

equipe escolar, favoráveis à

pais e alunos. inclusão e as reais atitudes

inclusivas dos

educadores Os

pais acreditam na

inclusão escolar,

tem

conhecimento

sobre de

modificações

realizadas pela

escola, porém

desconhecem as

estratégias;

percebem

a

desvantagem

pedagógica,

insegurança e

interferência na

autoimagem. Os

alunos sentem-se

inseguros, pela

participação, 
Barbosa, E. T.; Analisar a As crenças que o Souza, V. L. T. percepção e as professor tem (2010). A vivências de sobre os alunos vivência de professores com necessidades professores

sobre processo inclusão: sobre seu

o papel na influenciam o seu um alunos com los estudo da necessidades perspectiva da educacionais Psicologia especiais.

HistóricoCultural. Rev. Outro aspecto Psicopedagogi pretendeu $a, 27(84), 352-$ investigar diz 62. respeito aos sentimentos vividos por professores e alunos com necessidades educacionais especiais

\section{Cruz, M. B. Problematizar Articular}

(2011). as bonecas,

Bonecas, diversidade e his inclusão: que

brincando com as diferenças.

Rev.

Psicopedagogi $a, 28(85), 41-$ 52.

historicamente diversidade no
fazem parte das brincadeiras infantis representam os ideais infância sociedade.

da
é um desafio pois pressupõe a compreensão da alteridade.

e necessário a desfazer tramas especiais

Professores de uma escola pública responderam a entrevistas semiestruturadas e foi realizada observações em vários espaços da escola.

Relato experiência, que consistiu em apresentar às crianças uma coleção bonecas exclusão e abrir espaço para as múltiplas formas de ser sujeito dentro de uma cultura e um tempo histórico

\section{É} bonecos

"diferentes": negros, idosos, Síndrome Down, grávidas, entre outros, que foram incluídos nas suas brincadeiras.

Descreveram-se as práticas discursivas que emergiram das conversas, atitudes e interações nas brincadeiras, para entender como as crianças operavam tais conceitos. exposição e baixo acadêmico.

Os professores possuem percepções que se contrapõem aos pressupostos da educação inclusiva. Além disso, percebe-se que professores também são afetados com essa questão, pois o fato de não saberem como trabalhar com o aluno provoca mal-estares que os levam a buscar fora de sua sala de aula e de sua prática docente as causas para $o$ insucesso que vivenciam.

O estudo aponta que a possibilidade de brincar com bonecas

diferentes, que

e representam a diversidade,

favorece atitudes mais inclusivas e a aceitação das diferenças. rendimento . 
\& Rossetti, C. há diferença de também estudam com um B. (2012). no conceito de compreender a autista em classe Inclusão: um amizade, no experiência da inclusiva e 17 enfoque respeito às inclusão sob $o$ piagetiano diferenças e olhar das crianças sobre as nos nesse contexto relações de relacionament amizade no os entre pares contexto no contexto escolar. Rev. escolar.

Psicopedagogi a, 29(90), 30112.

que estudam em

classe nãoinclusiva, entre 7-8 anos. Foram criados catorze cartões com desenhos de crianças em diversas situações, para que participante indicasse se aquelas crianças poderiam ou não ser amigas.

Também foi utilizado um roteiro entrevista de baseado método clínico piagetiano.
Barbosa, A. J. Identificar as A

G., Campos, R. percepções de professor-aluno é A., $\quad \&$ professores fundamental para Valentim, T. quanto

A. (2011). A relação diversidade em professorà o

sala de aula e a aluno, a partir relação da aplicação professorda Escala de aluno. Estudos Relacionament de Psicologia o Professor (Campinas), aluno. 28(4), 453-

461.

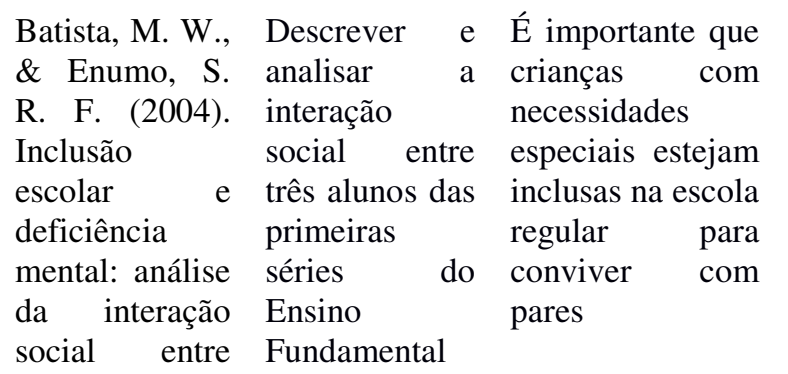
companheiros. com desenvolvimento integral das crianças 


$\begin{array}{ll}\text { Estudos de } & \text { Deficiência } \\ \text { Psicologia } & \text { Mental (DM) } \\ \text { (Natal), 9(1), } & \text { e seus colegas } \\ \text { 101-111.. } & \end{array}$

analisada através da aplicação de testes

sociométricos com perguntas

sobre três

escolhas e três

rejeições para

brincar e realizar

tarefas escolares;

foram filmadas

15 sessões de

observações na

situação de

recreio, cinco

para cada um

dos três sujeitos

focais.
Discutir o O professor é a Pesquisa

Menegotto, L. discurso de peça chave para a

M., Martini, F. professores promoção

O., \& Lipp, L. sobre

a inclusão.

K. (2010). inclusão de

Inclusão de alunos com

alunos com Síndrome de

síndrome de Down.

Down:

discursos dos

professores.

Fractal:

Revista de

Psicologia,

22(1), 155-

168.

Ávila, C. F., Objetivou a A maioria dos Foi utilizado Tachibana, M., investigação

\& Vaisberg, T. psicanalítica estudos psicológicos

M. J. A. do imaginário sobre o tema (2008). Qual é coletivo de desconsidera as o lugar do professores de din

aluno com

deficiência? O

imaginário

coletivo de escolar.

superior sobre

afetivo-

emocionais

professores.

professores

sobre

a

inclusão

escolar.

Paidéia

(Ribeirão

Preto), 18(39),

155-164. qualitativa de

caráter

exploratório. Foi

realizada uma

entrevista

semiestruturada

com professores

de alunos com

Síndrome de

Down, que foi

submetida à

análise de

conteúdo

qualitativa.

\section{Desenhos-}

Estórias com

Tema como

recurso

mediador-

dialógico,

cabendo a cada

professor

produzir,

individualmente,

desenhos

histórias sobre o

tema "aluno de

inclusão",

partir de uma

perspectiva

psicanalítica iniciar, manter e

finalizar os

contatos sociais com os colegas.

Os professores manifestaram sentimento de desamparo, impotência e incompetência frente à inclusão.
Revelou angústia despertada pelo processo de inclusão escolar nos professores que, em seu imaginário, concebem que o aluno com deficiência deve ser cuidado por sua mãe. Desse modo, compreende-se que o processo de inclusão demanda, além de informações técnicas, um espaço de cuidado emocional a estes profissionais.

(n)


T., Couto, T. imaginário

H. A. M., \& coletivo Vaisberg, T. M. J. A

(2009).

imaginário

coletivo

estudantes de

educação física

sobre pessoas

com

deficiência.

Psicologia \&

Sociedade,

21(2), 250-

255.

Psicologia \&

Sociedade,

25(1), 174-

184. técnico é tão disciplina de coletivo de importante Educação Física estudantes de Educação

O Física sobre pessoas com deficiência

quanto captar o imaginário

coletivo

campo do saber específico

adaptada

pesquisa por

meio do

Procedimento de

Desenhos- rodeia todo

participaram da

Estórias com

Tema, sendo

solicitado aos

estudantes que

desenhassem e

escrevessem

uma história

sobre o tema

"uma criança

com problema".

O material

obtido foi

psicanaliticamen

te analisado à

luz da Teoria

dos Campos.

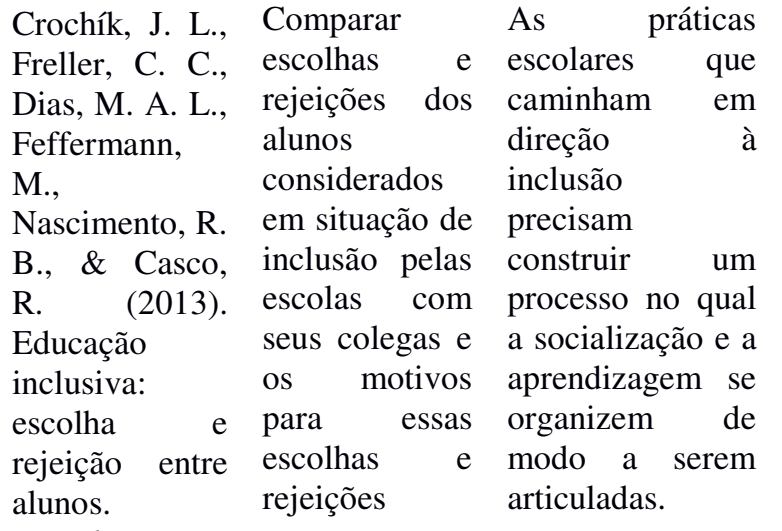

Gomes, C., \& Explorar as

Rey, F. L. G. representações (2007).

Inclusão

compartilhada

escolar:

$\mathrm{s}$ por vinte $\mathrm{e}$

representações

cinco

compartilhadas

de

profissionais

da educação

A mudança para

o enfoque social

da vida das

pessoas com

necessidades

especiais esbarra

em aspectos

profissionais

da educação

da rede regular

subjetivos que há

acerca da

inclusão

de ensino

e estigmatizam

escolar.

acerca

inclusão

Psicologia:

escolar

de

Ciência

$e$ alunos com
Escala

Proximidade

entre alunos, que

foi aplicada em

duas classes:

uma do ensino

público (um

aluno

considerado em

situação de

inclusão) e outra

do ensino

particular (três

alunos

considerados em

situação inclusão)

distintas

atribuições no

dos alunos sobre

deficiência

emergem a partir

de dois campos

psicológicos não-

conscientes:

"deficiência

como sofrimento

humano" e

"deficiência

como problema

técnico".

Não houve

diferenças entre

os dois grupos de

alunos, em ambas

as classes, no que

se refere à

frequência de

escolha ou

rejeição e em

relação aos

motivos. Os

motivos dados

para escolher ou

não colegas para

a execução de

tarefas escolares

denotam um ideal

de produtividade

e relações de competição

Vinte e cinco Enquanto não

profissionais de forem

compreendidas as

âmbito escolar desejos, as

participaram da frustrações e os

pesquisa, Os afetos dos

sistemas professores

conversacionais quanto a sua ação

foram firmados profissional, eles

entre a não poderão a

pesquisadora e assumir o papel

os participantes, de educar todo e

direcionados qualquer aluno e,

para exploração dessa forma, a 
Profissão, necessidades 27(3), 406- especiais. 417.
Crochík, J. L., Analisar O texto apresenta Dias, M. A. L., professores em professores que Feffermann, relação à trabalham em M., B., \& Casco, R. (2009). Atitudes de professores em relação à educação inclusiva.

Psicologia:

Ciência

Profissão,

29(1), 40-59.

\section{educação}

inclusiva

à

escolas

particulares com

experiência

talvez sejam mais

favoráveis à

educação

inclusiva,

explicitem mais

benefícios

menos condições

para que seja

bem sucedida. $\mathrm{Na}$

sequência desse Freller, C. C., atitudes de a hipótese de que contínuo,

estariam os

professores de

escola pública

com experiência,

os professores de escolas

particulares sem experiência e, por

fim,

os

professores de

escolas públicas

sem experiência

com educação

inclusiva.

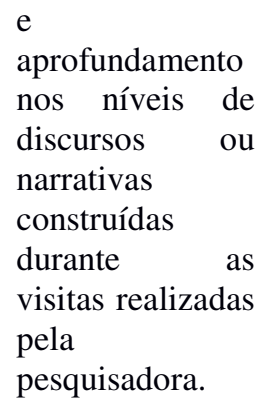

fatores da escala, posição frente à educação inclusiva,

Houve consenso a favor da educação inclusiva, seu favorecimento à socialização e a de aprendizagem dos benefícios prejuízos educação inclusiva para os alunos condições

As alunos com deficiência e de que sua presença não atrapalha a aprendizagem dos e demais alunos. Foram apontadas como condições favoráveis:

recursos humanos, diminuição do e total de alunos da em sala e restrição ao número de alunos e com deficiência necessárias para necessidade de a implementação especialização em da educação educação inclusiva.

inclusiva, participação de especialistas e apoio de outro professor em sala. Verificou-se o julgamento de que os alunos sem deficiência se consideram superiores àqueles que têm deficiência.

Sant'Ana, I. Investigar a Mudanças no Dez professores Docentes e M.. (2005). concepção de sistema e seis diretores Educação professores inclusiva: sobre concepções de inclusão professores e escolar diretores.

Psicologia em Estudo, 10(2), educacional são a necessárias para garantir cumprimento dos objetivos da inclusão, para tanto é necessário de escolas públicas do

\section{Ensino}

Fundamental

participaram de entrevistas semiestruturadas diretores

conceberam a

educação

inclusiva sob

diferentes

enfoques, com

definições que ora se 


$\begin{array}{lllr}\text { Tessaro, N. S., } & \text { Verificar a } \\ \text { Waricoda, A. } & \text { visão de } \\ \text { S. } & \text { R., } & \text { alunos sem } \\ \text { Bolonheis, R. } & \text { necessidades } \\ \text { C. M., \& Rosa, } & \text { educativas } \\ \text { A. P. } \quad \text { B. } & \text { especiais sobre } \\ \text { (2005). } & \text { a inclusão } \\ \text { Inclusão } & \text { escolar } \\ \text { escolar: visão } & \\ \text { de alunos sem } & \\ \text { necessidades } & \\ \text { educativas } & \\ \text { especiais. } & \\ \text { Psicologia } & \\ \text { Escolar } & \\ \text { Educacional, } & \\ \text { 9(1), 105-115. }\end{array}$

9(1), 105-115.
Scorsolini-

Comin, F., \&

Amorim, K. S.

(2010). "Em

meu gesto

existe o teu

gesto":

corporeidade

na inclusão de

crianças

deficientes.

Psicologia:

Reflexão

Crítica, 23(2),

261-269. considerar

dificuldades

vivenciadas pelos

participantes

profissionais que

tentam viabilizá-

la.

É imprescindível

ampliar

conhecimento,

desenvolver e testar formas que

realmente

viabilizem

inclusão escolar

que significa

incluir todas as

pessoas,

independentemen

te de seu talento,

deficiência, nível

socioeconômico

ou cultural, em

salas de aula com

todas as suas

necessidades

sendo atendidas.

Objetivou-se $\mathrm{O}$ olhar dos investigar a outros sobre as questão corporeidade deficientes deriva de crianças e com Paralisia

Cerebral processos inclusão.

em

simultaneamente orientam as práticas

concepções que são construídas contínua mutuamente em situadas relações entre essas crianças e os concepções

sobre educação

inclusiva,

desenvolvimento

do processo de

inclusão

condições

necessárias

efetivação

educação

inclusiva.

dados transcritos

foram

submetidos de

conteúdo

Participaram da

pesquisa

alunos

40

escolas públicas

de ensino básico

com vivências

diferentes

quanto

inclusão

à

alunos que
participavam da

inclusão escolar

e 20 que não

participavam).

Foi utilizado um questionário

composto por

três questões

abertas. Os

dados foram

examinados

mediante análise

de conteúdo e

análise

estatística.

Duas crianças com Paralisia Cerebral,

inclusas no

ensino regular

foram filmadas

no ambiente pré-

escolar. Foram

feitas entrevistas

com os pais,

profissionais de

saúde,

e

funcionários das

instituições de

ensino. As aproximavam dos

princípios de

integração, ora se

referiam à

orientação

inclusiva. As

principais

dificuldades

indicadas para a

realização da

inclusão

referiram-se à

falta de formação

especializada e de

apoio técnico no

trabalho com

alunos inseridos

nas classes

regulares

A maioria dos participantes

demonstrou

credibilidade à inclusão escolar, e apontaram várias

dificuldades

envolvidas nesse

processo,

destacando-se a

discriminação

social.

Os

sentimentos

decorrentes da

inclusão que

predominaram

entre os

participantes

foram positivos.

A partir da noção de corporeidade, abrem-se mais formas de conceber, analisar e discutir não só o desenvolvimento da criança e de seus pares, como a própria inclusão, seus atores, contextos e instituições. 
Sanches, A. C. Investigar as G., \& Oliveira, representações (2011).

Educação inclusiva

alunos transtorno mental: desafio interdisciplinar

- Psicologia:

Teoria

Pesquisa,

$$
e
$$
27(4), 411418 . Márcia A. F. sociais das

$\begin{array}{llr}\text { outros, em } & \text { gravações foram } \\ \text { função e a partir } & \text { transcritas r e } \\ \text { de seus corpos, } & \text { divididas por } \\ \text { produzindo } & \text { ambiente r de } \\ \text { significações, } & \text { ocorrência. For } \\ \text { posições } & \text { ealizada análise } \\ \text { identidades } & \text { microgenética } \\ \text { sociais de modo } & \text { das cenas com } \\ \text { dinâmico. } & \text { base } & \text { na } \\ & \text { perspectiva } \\ & \text { teórico- } \\ & \text { metodológica da } \\ & \text { Rede } & \text { de } \\ & \text { Significações. }\end{array}$

Existe uma ideia de que a loucura não é parte da esfera ou de competência das proposições do processo ensino e ou aprendizagem regular ou especial que serve para fortalecimento de paradigmas que estabelecem uma linha divisória entre "normal" e "anormal".

Foram

Os profissionais realizados dois da saúde e estudos de casos, educação passam de natureza ao largo das descritiva, a proposições da partir de Educação entrevistas Inclusiva semiestruturadas sobretudo, não há e gravadas, com discussões duas mães com filhos com diagnóstico de transtorno

de
mental, segundo a teoria das Representações Sociais, sob a perspectiva da Psicologia Social Crítica/.

Montilha, R. Identificar Ao considerar C. I., características também o meio Temporini, E. pessoais e circundante à R., Nobre, M. percepções de pessoa I. R. S., escolares Gasparetto, M. portadores de como deficiente, E. R. F., \& deficiência novas questões se José, N. K. visual em apresentam e (2009). relação ao seu possibilidades se Percepções de processo de avistam. escolares com escolarização. deficiência visual em relação ao seu processo de escolarização.

Paidéia

(Ribeirão

Preto), 19(44), 333-339.

Vinte e seis

estudantes de 12

anos e mais,

portadores de

deficiência

visual, inseridos

no sistema

público de

ensino 


$\begin{array}{lr}\text { "The } & \text { SAS } \\ \text { System } & \text { for } \\ \text { Windows" } & \text { foi } \\ \text { realizada } & \text { a } \\ \text { distribuição } & \text { de } \\ \text { frequências, } & \\ \text { medidas } & \text { de } \\ \text { posição e } & \text { de } \\ \text { dispersão. } & \end{array}$

\subsubsection{Análise e discussão da segunda categoria de publicações.}

A maioria dos artigos, incluídos nessa categoria, são provenientes de uma revista de psicopedagogia. Cintra et al. (2009) avaliaram as expectativas de pais de alunos matriculados em turmas inclusivas; Gomes e Souza (2009a) exploram a representação de professores sobre o fracasso escolar; Gomes e Souza (2009b) exploram aspectos organizacionais, institucionais e relacionais que sustentam as dinâmicas escolares inclusivas; Rocha et al. (2009) verificaram as crenças de pais e educadores de crianças disléxicas; Barbosa e Souza (2010) analisaram a percepção de professores sobre seu papel na inclusão de alunos com necessidades educativas especiais; Cruz (2011) descreveu práticas discursivas que emergiram de criança manipulando bonecos representativos de diferentes grupos sociais; Ricardo e Rossetti (2012) verificaram o conceito de amizade entre pares no contexto escolar. Pode-se notar que os artigos publicados em revistas de psicopedagogia dedicaram-se a estudar diferentes âmbitos relativos à inclusão escolar, perpassando desde aspectos institucionais e organizacionais, até concepções de pais, alunos e professores.

Quatro estudos foram publicados em revistas de escopo generalista em psicologia. Batista e Enumo (2004) analisaram a interação social de alunos com Deficiência Mental. Avila, Tachibana e Vaisberg (2008) investigaram o imaginário coletivo de professores de ensino superior sobre inclusão escolar. Oliveira-Menegotto, Martini e Lipp (2010) discutiram o discurso de professores sobre a inclusão de alunos com Síndrome de Down; Barbosa, 
Campos e Valentim (2011) identificaram as percepções de professores quanto à relação professor-aluno. Essas publicações centraram-se, em sua maioria, na concepção de professores sobre a inclusão escolar.

Quatro artigos foram retirados de revistas que tratam da interface entre psicologia e educação. Artioli (2006) discutiu os conceitos de inclusão e integração, apresentou a visão de professores sobre alunos com deficiência e discutiu a implicação do conhecimento prático e teórico sobre a deficiência, numa postura mais favorável ao processo integracionista. Tessaro et al. (2005) verificaram a visão de alunos sem necessidades educativas especiais sobre a inclusão escolar e Ohl et al. (2009) apresentaram narrativas de jovens com e sem deficiência sobre sua trajetória escolar. Pode-se observar que essas publicações centraram-se nas concepções de alunos, com prevalência daqueles sem necessidades educativas especiais. Rodrigues, Moreira e Lerner (2012) buscaram compreender as concepções de professores sobre alunos com TGD ou Autismo no ensino comum e as posições assumidas perante os alunos, com base em tais concepções.

Dois trabalhos foram publicados em revista destinada à relação entre psicologia e sociedade. Russo, Couto e Vaisberg (2009) estudaram o imaginário coletivo de estudantes de Educação Física sobre pessoas com deficiência e Crochík, Freller, Dias, Feffermann e Nascimento (2013) compararam escolhas e rejeições de estudantes em situação de inclusão escolar por seus pares.

Um artigo (Vitta, 2010) é proveniente de uma revista cujo objetivo é a produção acadêmica sobre educação, gênero e raça. Nesse trabalho, a autora verifica as concepções de berçaristas relativas à inserção de crianças com necessidade educativas especiais na rotina das atividades desenvolvidas. Um artigo, proveniente de uma revista de orientação psicanalítica, discutiu a transmissão simbólica entre alunos de uma escola (Rahme, 2010).

O consenso dos artigos dessa categoria é a defesa da consideração da subjetividade 
como relevante para o sucesso do processo de inclusão escolar. Observa-se um leque de teses que fundamentam os artigos desta revisão e que se inter-relacionam: a relevância das concepções dos professores para a inclusão escolar; a importância de se considerar a relação educação, socialização e inclusão; a importância de se considerar a relação entre inclusão escolar e o desenvolvimento dos alunos inclusos; a necessidade de considerar a influência que os aspectos relacionados aos sistemas de ensino exercem, como, por exemplo, a gestão escolar, o tipo de escola e a etapa de escolarização. Foram pontuados também a relevância da formação profissional, a estrutura física e a capacitação técnica para a promoção da inclusão escolar.

Do ponto de vista metodológico, predominam os estudos empíricos, com o uso de escalas e outros instrumentos, como, por exemplo, testes sociométricos (Batista \& Enumo, 2004); Escala de Relacionamento Professor - Aluno (Barbosa et al., 2011; Desenhos-Estórias com temas (Ávila et al., 2008; Russo et al., 2009); Escala de Atitudes frente à Educação Inclusiva (Crochik et al., 2009); Escala de Proximidade (Crochik, 2013). Na sequência, aparecem estudos que utilizam entrevistas (Sant'Ana, 2005; Ohl et al. 2009; Vitta, 2010; Rodrigues et al., 2012; Barbosa \& Souza., 2009; Oliveira-Menegotto et al., 2010); seguidos por estudos com questionários (Tessaro, 2005; Artioli, 2006; Cintra et al., 2009; Montilha et al., 2009; Rocha et al., 2009); estudos que trazem relato de caso e de experiência (Rahme, 2010; Cruz, 2011; Sanches \& Oliveira, 2011); estudos que utilizam sistemas conversacionais (Gomes \& Rey, 2007; Gomes \& Souza, 2009a; Gomes \& Souza, 2009b); análise microgenética (Scorsolini-Comin \& Amorim, 2010); análise institucional do discurso (Rodriges et al., 2012). O forte uso de entrevistas e questionários, que, juntos, respondem pela maioria da estratégia metodológica utilizada nesses artigos, talvez se explique pela relação com o objeto de estudo dos trabalhos classificados nessa categoria, que, em geral, buscava acessar as concepções dos profissionais, pais e alunos envolvidos na inclusão escolar. 
A maioria dos estudos (14) foi realizada em escolas públicas, seguida das escolas particulares (3) e de estudos que foram realizados tanto em escolas públicas como em escolas privadas (2). Alguns estudos não delimitaram o tipo de escola em que a pesquisa foi realizada. Em relação à etapa de ensino, a maioria dos estudos (14) foi realizada no âmbito do Ensino Fundamental, seguida de pesquisas desenvolvidas na Educação Infantil e no Ensino Fundamental (3), de estudos desenvolvidos no Ensino Superior (2), na Educação Infantil e creche (2). Nenhum trabalho foi realizado no âmbito do Ensino Médio. A ausência pesquisas para esse nível reflete a constatação do enfraquecimento do processo da inclusão escolar, que tem sido observado na etapa final da escolarização básica (Brasil, 2014).

Destaca-se, nessa categoria, o fato de apareceram dois estudos realizados no âmbito de Escolas Especiais: Barbosa e Souza (2010) e Sanches e Oliveira (2011). O primeiro texto destinou-se a investigar as concepções de professores sobre seu papel na inclusão de alunos com necessidades especiais e o segundo texto investigou as representações sociais de famílias de alunos com Transtornos Mentais.

Reiteradamente, foi trazida a necessidade de abordagem das crenças que subsidiem a prática pessoal e profissional. De forma geral, o consenso a esse respeito é de que as concepções acerca da inclusão baseiam e determinam as posições assumidas no cotidiano escolar, além de também fundamentarem suas práticas pedagógicas (Rocha et al., 2009; Barbosa \& Souza, 2010; Scorsolini-Comin \& Amorim, 2010; Rodrigues \& Lener, 2012).

As concepções dos professores a respeito da inclusão, presente no trabalho de Oliveira-Menegotto et al. (2010), são contraditórias, pois apontam um posicionamento a favor da inclusão escolar e, ao mesmo tempo, uma mobilização de sentimentos, tais como o desamparo e a angústia, frente às questões de sua prática profissional cotidiana. Merece destaque, especificamente, o trabalho de Rodrigues et al. (2012) que buscou compreender as concepções de professores sobre alunos diagnosticados com transtorno global do 
desenvolvimento. Um dos resultados, desse trabalho, refere-se ao fato de que os professores entendem como grande desafio à inclusão escolar a ausência de padrão entre os alunos. Esse resultado é particularmente interessante à medida que se relaciona com uma das grandes questões filosófico-teóricas da Psicologia do Desenvolvimento.

Quatro artigos focaram a percepção de estudantes regulares que conviviam com colegas inclusos. Rahme (2010) utilizou-se de uma perspectiva psicanalítica para estudar a relação de uma criança com transtorno invasivo do desenvolvimento e seus colegas de sala, sendo observados ganhos sociais para o participante. Ricardo e Rossetti (2012) investigaram o conceito de amizade de crianças que estudavam em turmas inclusivas e outras que não estudavam em turmas inclusivas. Os estudantes de classe inclusiva pareceram mais dispostos a respeito de se relacionar com alunos inclusos. Batista e Enumo (2004) descreveram e analisaram a interação social entre três alunos com deficiência intelectual e seus colegas de classe. Em conclusão, tem-se que os alunos com deficiência mental são menos aceitos e mais rejeitados que seus colegas. Crochik et al. (2013) pesquisaram as escolhas e as rejeições de estudantes regulares em relação aos seus colegas inclusos. Os motivos dados para escolher ou não colegas para as tarefas denotavam um ideal de produtividade e relações de competição.

Três artigos abordaram a expectativa de pais acerca da inclusão escolar. Desses três artigos, dois combinaram o discurso de pais e professores, Cintra et al. (2009) e Rocha et al. (2009). Os resultados apontam, respectivamente, para divergência entre as expectativas de pais e professores e para a crença, por parte dos pais, na inclusão escolar. Sanches e Oliveira (2011) focaram especificamente nas representações sociais de famílias de alunos com transtorno mental. Esse estudo conclui que, na percepção dos pais, os profissionais da saúde e da educação passam ao largo das proposições da educação inclusiva. Em síntese, apesar de acreditar nas proposições sobre a inclusão escolar, os pais observam aspectos a serem melhorados. 
A maioria dos artigos, incluídos nessa categoria, discute as concepções de pessoas pais, alunos e professores - sobre a inclusão escolar, sem delimitar qual o diagnóstico ou a dificuldade de aprendizagem que produz a necessidade da inclusão escolar. Como exemplo, podem ser citados os trabalhos de Sant'Ana (2005), Artioli (2006), Gomes e Rey (2007), Ávila, Tachibana e Vaisberg (2008), Crochik et. al (2009), Gomes e Souza (2009b), Russo, Couto e Vaisberg (2009), Barbosa e Souza (2010), Vitta (2010), Barbosa, Campos e Valentim (2011), Cruz (2011) e Ricardo e Rossetti (2012).

Entre os trabalhos que delimitam um diagnóstico ou a dificuldade que produz a necessidade de inclusão escolar, a maioria versou sobre os Transtornos Globais do Desenvolvimento e Autismo (Cintra, Rodrigues \& Ciasca, 2009; Rahme, 2010; Rodrigues et al., 2012), seguidos por trabalhos que envolveram mais de um diagnóstico (Tessaro et al., 2005 e Ohl et al., 2009) e por aqueles que se referem ao fracasso escolar (Gomes \& Souza, 2009a), à dislexia (Rocha et. al., 2009), à deficiência intelectual (Batista \& Enumo, 2004), à Síndrome de Down (Oliveira-Menegotto, Martini \& Lipp, 2010) e à Paralisia Cerebral (Scorsolini-Comin \& Amorim, 2010).

O que chama atenção nesses dados é a inversão da quantidade de trabalhos que abordam os Transtornos Globais do Desenvolvimento e Autismo, que aparecem em maior número, em face da menor quantidade de trabalhos que abordam a Deficiência Intelectual. Isso porque, esse último é o diagnóstico com maior prevalência de matrícula na escola regular, conforme o Censo Escolar (2014) do Distrito Federal.

A paralisia cerebral esteve presente em dois trabalhos, Ohl et al. (2009) e ScorsoliniComin e Amorim (2010). O trabalho de Ohl et al. (2009) apresentou narrativas de jovens com Deficiência Visual, Deficiência Motora e Paralisia Cerebral sobre sua trajetória escolar. O trabalho de Scorsolini-Comin e Amorim (2010) teve por objetivo investigar a corporeidade de crianças com Paralisia Cerebral em situação de inclusão escolar. Portanto, apenas um trabalho 
direcionou-se para questões relativas às especificidades do desenvolvimento de crianças com Paralisia Cerebral.

Nessa categoria, nenhum trabalho se remeteu especificamente à questão da matemática. Em se tratando de concepções a respeito da inclusão, observa-se a necessidade de pesquisas sobre as concepções que os próprios alunos têm sobre aprender ou sobre a importância e o uso da matemática e o que os professores ou pais acham de alunos aprenderem sobre isso. Tal espaço de pesquisa já havia sido sinalizado na introdução deste trabalho quando foram mencionadas as concepções particularmente relacionadas à competência matemática, dita racional e abstrata (Fávero \& Carneiro Soares, 2002; Fávero \& Oliveira, 2004) e, portanto, de difícil acesso às pessoas com necessidades educacionais especiais.

Ricardo e Rossetti (2012) defendem a tese de que é necessário compreender a experiência da inclusão escolar sob a ótica das crianças. Em Tessaro et al. (2005), as questões da pesquisa se direcionam para alunos regulares que convivem com alunos inclusos, sob o argumento de que é necessário desenvolver e testar formas que realmente viabilizem a inclusão. Em Ohl, et al. (2009), foi realizado um delineamento de pesquisa utilizando um grupo de alunos com deficiência e um outro grupo de alunos sem deficiência, sob a premissa de que, na escola, pode haver uma transformação nos processos de socialização para melhor atender às necessidades educacionais especiais. Nessa revisão, todavia, somente o trabalho de Montilha et al. (2009) focou exclusivamente estudantes com deficiência, no caso do estudo citado, a deficiência visual.

Outro aspecto que se destaca, nessa categoria, é a ausência de discussões que levem em consideração aspectos relacionados ao gênero, a classe social e a raça. A relevância da consideração desses aspectos na pesquisa foi estabelecida pelos estudos feministas (Beetham \& Demetriades, 2007 e Fávero, 2010). Além disso, não foi observado nenhum trabalho que 
tivesse por objetivo intervir nas concepções relatadas pelos participantes das pesquisas, com objetivo de auxiliar no processo de inclusão escolar. 


\subsubsection{A terceira categoria de publicações: artigos sobre a prática inclusiva.}

$\mathrm{Na}$ terceira categoria foram incluídos artigos que tratam especificamente da prática escolar inclusiva, sendo que treze trabalhos se encaixaram nesse conjunto. Em relação às características das revistas, um artigo é proveniente de um periódico de orientação psicanalista (Arantes, 2010). Um artigo é proveniente de uma revista que trata especificamente da psicologia da educação (Leite, Silva, Mennocchi \& Capellini, 2011). Um artigo foi publicado em uma revista com voltada para psicoterapia analítica grupal (Nascimento, Scapim \& Silveira, 2010). Um artigo é de uma revista de psicopedagogia (Machado \& Almeida, 2010). Um artigo é de uma revista de psicologia social (Jesus, 2004). Dois artigos são de uma revista que articula a psicologia com ciência humanas e ciências da saúde (Escolbal, Rossit \& Goyos, 2010; Souza, Hueara, Batista, Guarnieri \& Laplane, 2010). Dois artigos são de uma revista específica de psicologia escolar e educação (Leonardo, 2008; Rossit \& Goyos, 2009). Um estudo foi publicado na seção sobre psicologia do desenvolvimento de uma revista que trata também de avaliação psicológica, processos psicológicos básicos e psicologia da saúde (Cazeiro \& Lomônaco, 2011). As publicações incluídas nessa categoria estão apresentadas na Tabela 3.

Tabela 3

Artigos sobre a prática escolar inclusiva

\begin{tabular}{|c|c|c|c|c|}
\hline & Referência & Objetivos & Método & Resultados \\
\hline 1 & $\begin{array}{l}\text { Arantes, F. F. } \\
\text { (2010). De quem - } \\
\text { ou do quê - } \\
\text { depende o sucesso } \\
\text { da inclusão } \\
\text { escolar? Estilos da } \\
\text { Clínica, 15(1), 96- } \\
115 .\end{array}$ & $\begin{array}{l}\text { Visa discutir a } \\
\text { avaliação e o êxito } \\
\text { educacional das } \\
\text { crianças incluídas } \\
\text { em escolas } \\
\text { regulares, } \\
\text { discutindo } \\
\text { experiência a } \\
\text { inclusão de uma } \\
\text { criança } \\
\text { Transtornos }\end{array}$ & $\begin{array}{l}\text { O desenvolvimento e Artigo teórico que } \\
\text { a aprendizagem dos aborda a questão } \\
\text { alunos devem ser da adequação } \\
\text { feito com base no curricular } \\
\text { progresso por ele estabelecimento } \\
\text { realizado, o que traz dos objetivos de } \\
\text { uma grande aprendizagem e } \\
\text { responsabilidade ao traz um relato de } \\
\text { professor, pois é experiência da } \\
\text { preciso que ele autora como } \\
\text { analise }\end{array}$ & $\begin{array}{l}\text { Ainda há aspectos } \\
\text { sobre a efetivação da } \\
\text { inclusão escolar que } \\
\text { precisam ser } \\
\text { respondidos e a tese } \\
\text { do trabalho, apesar } \\
\text { de ser uma ideia boa } \\
\text { e atual, não fecha } \\
\text { sentido em si mesma. }\end{array}$ \\
\hline
\end{tabular}




\begin{tabular}{|c|c|c|c|c|c|}
\hline & & 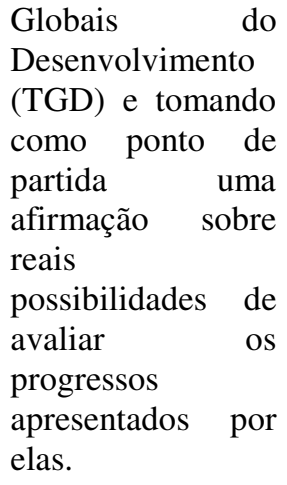 & $\begin{array}{l}\text { necessidades e os } \\
\text { objetivos individuais } \\
\text { dos alunos, e } \\
\text { esperança, uma vez } \\
\text { que os objetivos } \\
\text { podem ser } \\
\text { maleáveis, de acordo } \\
\text { com o sujeito em } \\
\text { questão. }\end{array}$ & $\begin{array}{lr}\text { criança } & \text { com } \\
\text { transtorno } & \text { global } \\
\text { do } & \\
\text { desenvolvimento. }\end{array}$ & \\
\hline 2 & 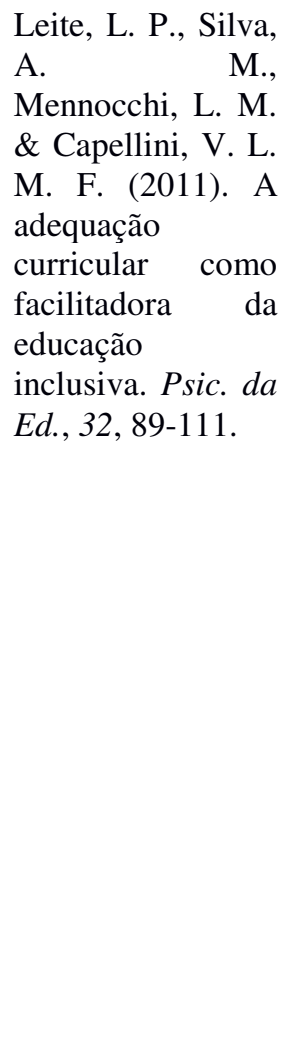 & $\begin{array}{lr}\text { Demonstrar } & \text { o } \\
\text { resultado } & \text { da } \\
\text { avaliação } & \text { da } \\
\text { efetivação de } & \text { uma } \\
\text { atividade prática } \\
\text { de adequação } \\
\text { curricular, } & \text { para } \\
\text { facilitar } & \text { o } \\
\text { progresso } & \\
\text { acadêmico } & \text { de } \\
\text { alunos } & \text { com } \\
\text { necessidades } & \\
\text { educacionais } & \\
\text { especiais. }\end{array}$ & $\begin{array}{lr}\text { Estamos } & \text { num } \\
\text { momento } & \text { de } \\
\text { fomentar } & \mathrm{e} \\
\text { apresentar } & \text { dados } \\
\text { decorrentes } & \text { de } \\
\text { pesquisas } & \\
\text { educacionais } & \text { que } \\
\text { envolvam } & \text { práticas } \\
\text { pedagógicas } & \text { que } \\
\text { favoreçam } & \text { o } \\
\text { progresso } & \\
\text { educacional } & \text { desse } \\
\text { alunado. } & \\
& \end{array}$ & 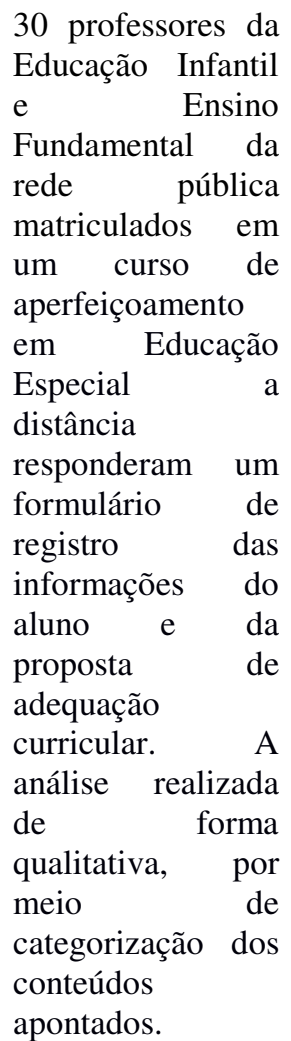 & $\begin{array}{l}\text { Percebeu-se que os } \\
\text { professores precisam } \\
\text { de orientações para } \\
\text { promover ajustes na } \\
\text { prática pedagógica } \\
\text { para facilitar o } \\
\text { processo de ensino e } \\
\text { de aprendizagem do } \\
\text { alunado com } \\
\text { necessidades } \\
\text { especiais, } \\
\text { principalmente } \\
\text { daqueles } \\
\text { apresentam que } \\
\text { deficiência } \\
\text { intelectual/mental }\end{array}$ \\
\hline 3 & $\begin{array}{l}\text { Nascimento, G. S., } \\
\text { Scapim, K. C. M., } \\
\& \text { Silveira, C. A. } \\
\text { B. (2010). Revista } \\
\text { da SPAGESP, } \\
11(2), 51-63 .\end{array}$ & $\begin{array}{l}\text { Apresentar um } \\
\text { estudo sobre a } \\
\text { integração de } \\
\text { alunos de inclusão } \\
\text { escolar por meio } \\
\text { de jogos } \\
\text { cooperativos, } \\
\text { abrindo } \\
\text { possibilidades para } \\
\text { a atuação do } \\
\text { psicólogo escolar } \\
\text { com grupos neste } \\
\text { contexto. }\end{array}$ & $\begin{array}{lr}\text { Os } & \text { jogos } \\
\text { cooperativos } & \text { são } \\
\text { importantes } & \\
\text { instrumentos } & \text { para } \\
\text { evidenciar } & \text { as } \\
\text { diferentes } & \text { maneiras } \\
\text { de o grupo } & \text { se } \\
\text { relacionar } & \mathrm{e} \\
\text { proporcionar } & \mathrm{a} \\
\text { socialização } & \mathrm{e} \\
\text { integração } & \text { dos } \\
\text { alunos } & \\
& \end{array}$ & $\begin{array}{l}\text { Estudo de caso } \\
\text { realizado com um } \\
\text { grupo de crianças } \\
\text { da segunda série, } \\
\text { cuja sala recebeu } \\
\text { alunos de inclusão. } \\
\text { Foram utilizados } \\
\text { diários de campo e } \\
\text { os dados foram } \\
\text { analisados } \\
\text { qualitativamente a } \\
\text { partir de } \\
\text { referenciais } \\
\text { teóricos sobre } \\
\text { jogos } \\
\text { cooperativos. }\end{array}$ & $\begin{array}{lr}\text { Os resultados } \\
\text { evidenciaram } \\
\text { importância do uso } \\
\text { dos } & \text { jogos } \\
\text { cooperativos } & \text { como } \\
\text { estratégia no trabalho } \\
\text { do psicólogo escolar } \\
\text { com grupos } & \text { no } \\
\text { processo } & \text { de } \\
\text { socialização } & \text { e } \\
\text { integração } & \text { das } \\
\text { crianças. }\end{array}$ \\
\hline
\end{tabular}

4 Machado, A. C., Avaliar os efeitos Defender a proposta Participaram do A atuação \& Almeida, M. A. de uma prática de de ensino estudo 22 alunos colaborativa entre o 


\begin{tabular}{|c|c|c|c|}
\hline $\begin{array}{l}\text { experiência } \\
\text { ensino } \\
\text { colaborativo par } \\
\text { educação } \\
\text { inclusiva. Re } \\
\text { Psicopedagogia, } \\
\text { 27(84): 344-351. }\end{array}$ & $\begin{array}{ll}\text { leitura pautada no } & \text { colaborativo como } \\
\text { ensino } & \text { para auxiliar a } \\
\text { colaborativo em melhora na qualidade } \\
\text { alunos de uma sala } & \text { de ensino. } \\
\text { regular. } & \end{array}$ & $\begin{array}{l}\text { do } 4^{\circ} \text { ano do } \\
\text { ensino regular, dos } \\
\text { quais um deles } \\
\text { apresentava } \\
\text { necessidades } \\
\text { educacionais } \\
\text { especiais. Por } \\
\text { meio da } \\
\text { abordagem } \\
\text { descritiva } \\
\text { observacional, os } \\
\text { resultados obtidos } \\
\text { neste estudo foram } \\
\text { coletados durante } \\
\text { o processo na sala } \\
\text { de aula. }\end{array}$ & $\begin{array}{l}\text { professore } \\
\text { especialista } \\
\text { generalista foi } \\
\text { considerada positiva } \\
\text { e isso justificou a } \\
\text { indicação da } \\
\text { necessidade de novos } \\
\text { estudos a respeito. }\end{array}$ \\
\hline
\end{tabular}

5 Heckert, A. L. C., Apresentar A inclusão é um Conversações, \& Andrade, R. B. reflexões sobre processo sempre em através de quatro (2010). Caminhos bifurcantes na educação inclusiva: inclusões e rebeldias silenciosas na educação pública. Fractal: Revista de Psicologia, 22(3), 497-512.

6 Oliveira, M. A., \& Leite, L. P. (2011). Educação inclusiva: análise e intervenção em uma sala de recursos. Paidéia (Ribeirão Preto), 21(49), 197-205.

o A sala de recursos e Descrição da sala funcionamento de seu de recursos, recursos e relevante para a de ensino, descrever a inclusão educacional aplicação de entrevistas e discussões sobre teoria e prática na educação inclusiva educação inclusiva curso, tratando-se de perguntas abertas, diferentes formas destinadas aos sociais de geração, educadores, para composição e cartografar os gerenciamento da processos de vida. inclusão gestados nas práticas educacionais.
A pesquisa realizada apontou que os modos instituídos que tecem a educação produzem o chamado fracasso escolar. Apontou ainda, que modos de educar podem revolucionar processos de inclusão.

Aponta a existência de divergências entre políticas uma sala de funcionamento é análise do plano com a professora especialista preenchimento do documento de adaptações curriculares. análise contou com os procedimentos: caracterização da realidade investigada, análise das entrevistas análise comparativa das adaptações curriculares. educacionais e realidade escolar investigada. A intervenção permitiu que a professora refletisse sobre a sua atuação com base em novos procedimentos de ensino. 
7 Jesus, D. M. Intervir (2004). Atuando processo em contexto: o avaliação

no É de prov

de $\begin{array}{lr}\text { processo } & \text { de } \\ \text { avaliação } & \text { numa }\end{array}$ perspectiva inclusiva.

Psicologia \& Sociedade, 16(1), 37-49.

8 Escobal, G., Investigar Rossit, R. A. S., \& processo Goyos, Celso. aquisição conceito (2010). Aquisição de conceito de número por número pessoas deficiência intelectual. Psicologia em Estudo, 15(3), 467-475. série, alterando a inclusão. lógica do ensino. propõe teórico que na lógica possibilidade de para atuação frente à

a inclusão escolar, relatando um caso de intervenção com um aluno com dificuldade de aprendizagem e intervenção junto às professoras da escola.

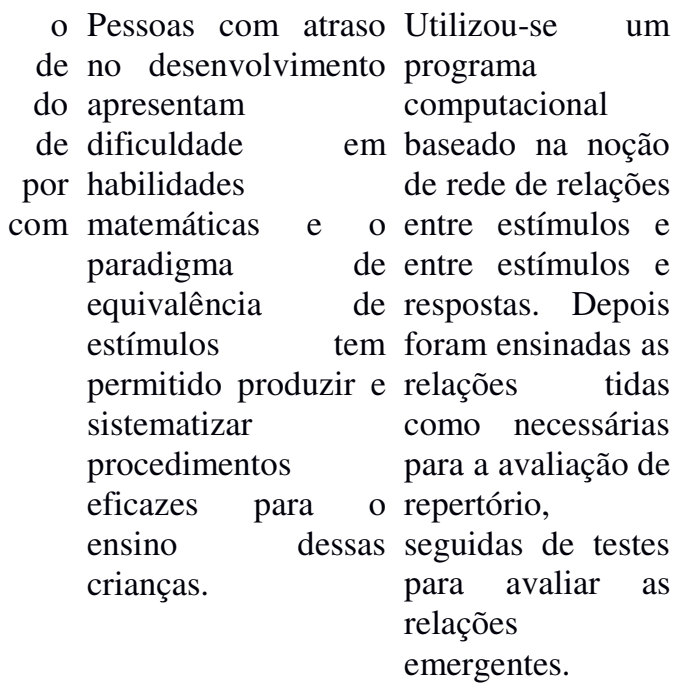
es procedimentos de ensino utilizados foram eficazes, sendo constatada a aquisição do conceito de número em pouco tempo. Formou-se uma rede de relações matemáticas a partir do ensino direto de apenas duas relações. O ensino informatizado otimizou o processo de ensinoaprendizagem, aumentou confiabilidade dos dados e controlou as contingências, de forma a ensinar conforme o planejado
9 Souza, C. M. L., Observar Hueara, Batista,

L., analisar Guarnieri,

C. formação

\& conceitos em um favoreçam

e É importante

a promoção

de situações

Laplane, A. L. F. (2010). Formação de conceitos por crianças com necessidades especiais.

Psicologia em Estudo, 15(3), 457-466. desenvolvido em crianças com Corpo Humano, um grupo com necessidades em que foram diagnóstico de educacionais utilizados deficiência visual. especiais, refletindo materiais quanto aos modos de adaptados intervenção. realizadas atividades demonstrativas do funcionamento dos sistemas. atendimentos envolviam levantamento de conhecimentos e
A explicação formal de conhecimentos científicos, de uma forma que incorpora experiências pessoais das crianças e, deste modo, se aproxima da realidade de cada uma delas, pode trazer alternativas favoráveis ao aprendizado de crianças com necessidades especiais. 
$\begin{array}{lr}\text { experiências } & \text { do } \\ \text { cotidiano sobre o } \\ \text { tema que } & \text { seria } \\ \text { abordado } & \text { e } \\ \text { vivências. } & \text { Todas } \\ \text { as sessões } & \text { foram } \\ \text { gravadas, } & \\ \text { transcritas } & \text { e } \\ \text { submetidas } & \text { à } \\ \text { análise } & \\ \text { microgenética. }\end{array}$

10 Leonardo, N. S. T. Verificar como O processo de Participaram da (2008). Inclusão está ocorrendo o inclusão ainda pesquisa treze escolar: um estudo processo de esbarra em professores que acerca da implantação de dificuldades tinham alunos com implantação da projetos inclusivos referentes a recursos necessidades proposta em em escolas humanos e materiais educativas escolas públicas. públicas de ensino no âmbito escolar. especiais em sua Psicologia Escolar básico. e Educacional, 12(2), 431-440. classe.

utilizado questionário composto quatro questões abertas. Os dados foram examinados mediante análise de conteúdo.
11 Rossit, R. A. S., \& Analisar Goyos, C. (2009). aquisição Deficiência intelectual aquisição matemática: currículo como rede de relações condicionais. Psicologia Escolar e Educacional, 13(2), 213-225. relações estímulos manusear e matemáticas apresentar currículo baseado dificuldades

a Com a expansão da Participaram de noção necessidades

e especiais, de pessoas deficiência intelectual entre 9 a 32 em estudantes no paradigma de diferentes níveis, é escola equivalência de importante tanto o Educação ensinar deficientes metodologias intelectuais dinheiro. a diversificadas ensino como procedimentos de Especial. estímulos de utilizados de palavras numerais flexíveis de modo a impressos, atender à diversidade imagens dos alunos. moedas e notas, componentes da adição, conjunto de moedas, notas e moedas juntas, preços impressos, moedas e notas verdadeiras.

Quatro estudos foram conduzidos para o ensino de diferentes

relações, através de um programa computacional.
A inclusão escolar vem se efetivando sem a infraestrutura adequada, seja em termos de recursos materiais seja de recursos humanos, podendo trazer mais $m$ prejuízos do que benefícios a quem dela faz parte

1 Demonstraram a eficácia do currículo como rede de relações e dos procedimentos

de utilizados, constatada

de a aquisição de habilidades

Os complexas num período de tempo reduzido. Uma ampla e complexa rede de relações matemáticas foi adquirida a partir do ensino direto de apenas algumas relações. 
12 Cazeiro, A. P. M., Investigar

\& Lomônaco, J. F. influência

B.

(2011).

Formação

conceitos

crianças

paralisia cerebral:

um estudo

exploratório sobre

a influência de

atividades lúdicas.

Psicologia:

Reflexão e Crítica, 24(1), 40-50. conceitos crianças sequelas a $\mathrm{O}$ desenvolvimento Pré-teste

de de conceitos conceitos atividades lúdicas espontâneos ocorre espontâneos, no processo de por meio do contato através do Teste formação de da criança com de Conceitos espontâneos paralisia cerebral. objetos e pessoas Básicos de por presentes em seu Boehm, sessões com ambiente. de individuais de atividades lúdicas que envolviam alguns dos conceitos avaliados reaplicação do teste inicial a fim de avaliar o grau de desenvolvimento dos conceitos.

13 Souza, A. M. L., Discutir \& Macedo, M. C. avaliação S. R. (2012). aprendizagem

a A avaliação da aprendizagem

da Artigo

Avaliação da escolar como meio escolar apresenta-se perspectiva aprendizagem e de inclusão escolar: a singularidade serviço coletividade. Psicologia Escolar e

Educacional, 16(2), 283-290. de inclusão/exclusão como elemento histórico importante para o cultural, enfrentamento das fundamentado em a partir da análise dificuldades de conceitos que
permeiam as duas temáticas. $e$ inerentes ao processo Luckesi de aprendizagem e Hoffman. Faz uma desenvolvimento dos progressão alunos, pois se histórica dos encontra no cerne da paradigmas da atividade educativa educação especial. escolar, fazendo assim um par dialético com a inclusão. de Todas as crianças participantes desenvolveram ao menos um dos conceitos mais vivenciados nas sessões de atividades lúdicas, além de terem desenvolvido outros conceitos espontâneos não avaliados por meio dos testes.

\subsubsection{Análise e discussão da terceira categoria de publicações.}

Os artigos que abordaram a prática escolar inclusiva - terceira categoria - centram-se em relatos de experiência, com diversidade de abordagens metodológicas. Dentre as quais se destaca o uso da cartografia, da análise do discurso, da análise de conteúdo, da análise microgenética e do paradigma de equivalência de estímulos.

Essa foi a única categoria em que apareceram estudos que envolvem a aprendizagem da matemática no processo inclusivo. Os dois artigos a esse respeito utilizaram a abordagem 
comportamental de equivalência de estímulos com participantes com deficiência intelectual. É possível notar, também, que os dois trabalhos são da mesma equipe de pesquisa (Rossit \& Goyos, 2009; Escobal, Rossit \& Goyos, 2010). Rossit e Goyos (2009) tratam do comportamento matemático constituído por componentes que se relacionam entre si, como o “conceito de número, operações básicas, conceitos monetários, conceitos relacionais de igual - diferentes, mais-menos, antes-depois, maior-menor, dentre outros" (Rossit \& Goyos, 2009, p. 214). No trabalho de Escobal, Rossit e Goyos (2010), que trata especificamente da aquisição do conceito de número, apesar da descrição da construção teórica do paradigma de estímulos, não encontramos referência ao que seria o próprio conceito de número.

A maioria dos estudos, aqui categorizados, buscou apresentar formas de atuação profissional. Elas são: a atuação de professores que trabalham com alunos em situações de inclusão escolar (Jesus, 2004; Leonardo, 2008; Arantes, 2010; Heckert \& Andrade, 2010; Machado \& Almeida, 2010; Nascimento et al., 2010); a atuação do psicólogo escolar no processo de inclusão escolar, abordada por Leite et al. (2011); e a atuação de uma professora especialista em sala de recursos, que foi descrita por Oliveira e Leite (2011).

Em relação aos relatos de intervenção com alunos, foram encontrados cinco trabalhos. Há a pesquisa de Jesus (2004), sobre a avaliação de um aluno com dificuldade de aprendizagem; o trabalho de Escobal et al. (2010), que trata da aquisição de número por estudantes com deficiência intelectual; o estudo de Souza et al. (2010), que observou e analisou a formação de conceitos por estudantes com deficiência intelectual; a pesquisa de Rossit e Goyos (2009), que analisaram aquisições de relações matemáticas por estudantes com deficiência intelectual através de manuseio de dinheiro e; o trabalho de Cazeiro e Lomônaco (2011), cuja investigação tratou da influência de atividades lúdicas na formação de conceitos por crianças com paralisia cerebral. 
Nos resultados dessa categoria, nota-se também a presença de preocupação em relação à predominância do modelo médico e, por outro lado, a defesa da atuação conjunta de professores e especialistas. Outro aspecto relevante sobre essa categoria é a defesa da formação continuada dos profissionais que lidam com a inclusão escolar e a necessidade de consideração do desenvolvimento particular de cada aluno incluso. O que se verifica é que os textos relacionam a prática profissional facilitadora da inclusão e a formação profissional. Esse aspecto será retomado na categoria a seguir. 


\subsubsection{A quarta categoria de publicações: formação profissional e inclusão.}

A quarta categoria, na qual foram classificadas seis publicações, aborda o tema da formação profissional para a atuação na inclusão escolar. Essa é a categoria com menor quantidade de publicações.

Nessa categoria estão incluídos dois artigos publicados em revistas de orientação psicanalítica (Bastos \& Kupfer, 2010; Freller, 2010). Três artigos foram publicados em revistas de psicopedagogia (Fabrício, Souza \& Gomes, 2007; Ferreira, Souza, Silva \& Dechichi, 2009; Araújo, Rusche, Molina \& Carreiro, 2010). Um artigo é proveniente de uma revista de psicologia escolar e educação (Barbosa \& Conti, 2011). Os artigos agrupados nessa categoria estão apresentados na Tabela 4.

Tabela 4

Formação profissional e inclusão

\begin{tabular}{|c|c|c|c|c|}
\hline & Referência & Objetivos & Método & Resultados \\
\hline 1 & $\begin{array}{l}\text { Bastos, M. B., \& } \\
\text { Kupfer, M. C. M. } \\
\text { (2010). A escuta de } \\
\text { professores } \\
\text { trabalho no } \\
\text { inclusão escolar de } \\
\text { crianças psicóticas } \\
\text { e autistas. Estilos } \\
\text { da Clínica, 15(1), } \\
\text { 116-125. }\end{array}$ & 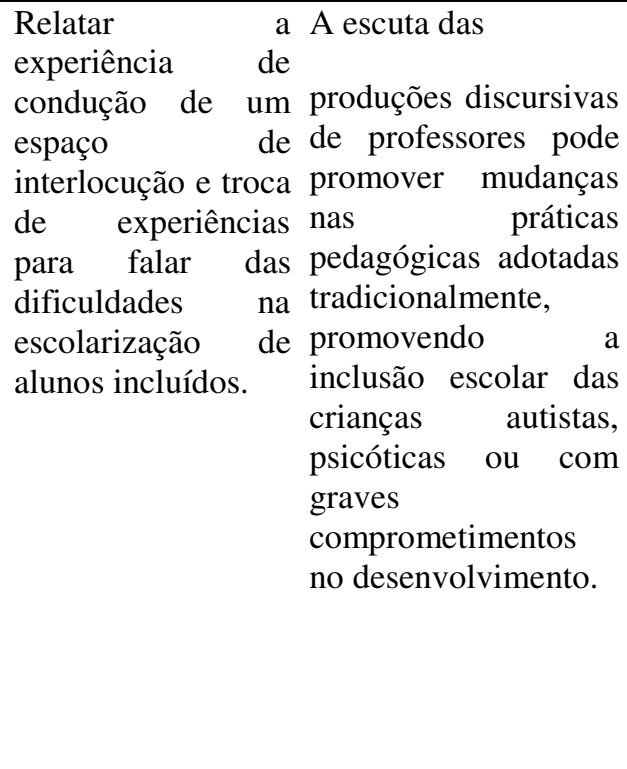 & $\begin{array}{l}\text { Artigo teórico que } \\
\text { relata o trabalho de } \\
\text { uma instituição que } \\
\text { atende crianças } \\
\text { autistas, psicóticas } \\
\text { ou com graves } \\
\text { comprometimentos } \\
\text { no } \\
\text { desenvolvimento, } \\
\text { com o grupo de } \\
\text { professores dessas } \\
\text { crianças. }\end{array}$ & $\begin{array}{lr}\text { O trabalho de } \\
\text { escuta processado } \\
\text { no grupo contribui } \\
\text { para que r se } \\
\text { instalem, perguntas } \\
\text { e } & \text { questões } \\
\text { referentes } & \text { às } \\
\text { interpretações } & \text { que } \\
\text { professores fazem } \\
\text { sobre seus } \\
\text { Assegurar alunos. } \\
\text { espaço de fala para } \\
\text { discutir r } r \\
\text { impasses r os } \\
\text { trabalho com essas } \\
\text { crianças, favorece } \\
\text { o vínculo dos } \\
\text { professores } \\
\text { grupo. com }\end{array}$ \\
\hline 2 & $\begin{array}{l}\text { Freller, C. C. } \\
\text { (2010). É possível } \\
\text { ensinar educadores } \\
\text { a incluir? Como } \\
\text { ensinar educadores } \\
\text { a ensinar alunos de }\end{array}$ & 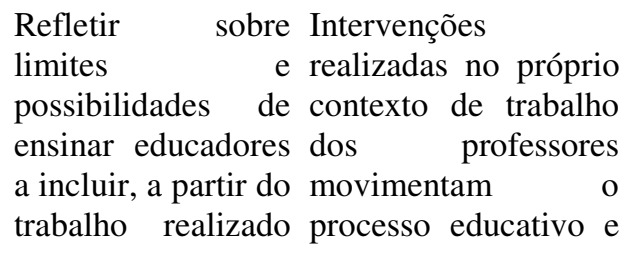 & $\begin{array}{l}\text { Artigo teórico que } \\
\text { relata um trabalho } \\
\text { de intervenção } \\
\text { quinzenal, com } \\
\text { professores, } \\
\text { gestores, porteiros, }\end{array}$ & $\begin{array}{l}\text { Os autores } \\
\text { concluem que se } \\
\text { deve incluir os } \\
\text { professores no } \\
\text { processo de tornar } \\
\text { as práticas }\end{array}$ \\
\hline
\end{tabular}




\begin{tabular}{lllcll}
\hline inclusão? Estilos & por uma equipe as relações escolares. & inspetores & de educativas mais \\
da Clínica, 15(2), terapêutica numa & alunos, & inclusivas, assim \\
$326-345 .$. & instituição & de & merendeiras, por como permitir \\
& ensino regular. & uma profissional experiências e \\
& & ligada a uma reflexões em que \\
& & instituição que os professores \\
& & atende crianças sejam incluídos e \\
& & autistas, psicóticas possam desdobrá- \\
& & ou com graves las para outras \\
& comprometimentos situações. \\
& no & \\
& desenvolvimento.
\end{tabular}

3 Ferreira, J. M., Discutir, com Há a necessidade de Reuniu-se nessa Souza, C. S., professores da se pensar em novas estratégia de Dechichi, C. aspectos relevantes para o contexto metodologia de (2009). Arte, sobre o educacional e em atuação baseada formação de desenvolvimento alternativas que nos modelos de professores e humano e renovem a concepção oficinas e a inclusão escolar: aprendizagem de de formação de utilização da arte Possibilidades de crianças com professores. como recurso atuação do necessidades lúdico de trabalho, psicólogo em educacionais conduzidas por um contextos especiais em idade educacionais, pré-escolar e o Cadernos de processo de Psicopedagogia, inclusão de das 7(13), 25-41. mesmas nas escolas de ensino regular, enfatizando o papel do educador nesse processo de escolarização. psicólogo escolar.

A prática resultou em momentos de formação que uniu o saber específico e científico objetivado à construção de um saber conjunto advindo das experiências e conhecimentos dos participantes e, sobretudo, um momento de reflexão crítica acerca do papel do educador e do processo de Inclusão Escolar.

4 Fabrício, N. M. C., Discutir É necessário que os Artigo teórico que Souza, V. C. B., \& características dos professores tenham propõe como o Gomes, E. E. A. S. professores que habilidades desafio a conversão (2007). Perfil do possam garantir específicas para prática dos professor inclusivo. práticas inclusivas trabalhar com salas de princípios de Rev.

Psicopedagogia, adequadas às aula heterogêneas. inclusão escolar. singularidades do Para tanto, discute aprendente.

\section{aspectos}

relacionados ao conhecimento e às atitudes dos professores.
Os autores apontam que é necessário que $\mathrm{o}$ professor tenha uma disponibilidade interna para inclusão. Que seja e resiliente e que se mantenha em permanente aprendizagem. Os aspectos que não estão presentes nas pessoas podem se desenvolver.

Prevalece a valorização da formação continuada, embora a preocupação com a formação inicial já exista. Aponta se a presença de ações formativas 
de resumos de artigos na base SciELO. Rev. Psicopedagogia, 27(84), 405-16. como base os educacionais

no filiação

resumos de artigos próprio, além de institucional dos publicados na auxiliar a outras autores, revistas SciELO até o pesquisas na que publicaram os primeiro semestre construção das práxis artigos, ano de de 2010 . e do planejamento das publicação, políticas públicas em palavras - chave, educação.

temática ou problemática,

objetivos, tipo de

deficiência,

referenciais

teóricos,

instrumentos,

sujeitos, resultados

e conclusões.

6 Barbosa, A. J. G., Efetuar um estudo Os cursos de 163 estudantes de \& Conti, C. F. transversal sobre a graduação devem ser cinco períodos de (2011). Formação formação de capazes de dois cursos de em psicologia e educação inclusiva: um estudo transversal. estudo

Psicologia Escolar e Educacional, psicólogos e a desenvolver atitudes Psicologia preparação positivas, princípios responderam a um recebida durante a éticos e compromisso questionário. graduação para social dos futuros atuar em escolas profissionais em inclusivas. relação a uma escola que acolha e promova o desenvolvimento de todos os alunos.

7 Dall'Acqua, M. J. Investigar aspectos É

necessário Pesquisa

C. (2007). Atuação de professores do ensino itinerante face à inclusão de crianças com baixa visão na educação infantil. Paidéia (Ribeirão Preto), 17(36), 115-122.

\section{relativos}

necessidades

às desenvolver trabalhos participante durante de pesquisa que se um ano letivo com manifestas por duas dediquem a analisar duas professoras e professoras itinerantes, as implicações da seus alunos. As formação continuada sessões iniciavamparticipantes de um de professores na se com diálogo programa de inclusão escolar.

formação continuada. sobre o ocorrido no encontro anterior, e observação das crianças participantes, seguido avaliação visão residual discussão sobre os próximos passos do planejamento, com base desempenho do aluno e nas proposições teóricas de Barraga, Morris, Collins e Hollis. baseadas em

processos de desenvolvimento e aprendizagem da docência, porém, a racionalidade técnica ainda se faz presente. Quanto à formação dos professores sobre a inserção dos deficientes na escola, a discussão é generalista.

Há evidências de que a graduação em Psicologia não tem sido capaz de alterar posicionamento dos estudantes quanto à educação inclusiva e de prepará-los para serem psicólogos escolares em escolas inclusivas.

Não teve discussão de categorias das necessidades (quais e de quais naturezas) das professoras, contudo a intervenção realizada junto a elas foi caracterizada como positiva. 


\subsubsection{Análise e discussão da quarta categoria de publicações.}

A discussão sobre a formação profissional e sua influência na promoção de práticas escolares inclusivas, como abordado na categoria anterior, é particularmente interessante, ao considerar que a quarta categoria desta revisão, relacionada às competências profissionais e inclusão escolar, foi a que apresentou a menor frequência de artigos. O foco dessa categoria é a formação profissional e a inclusão. Destaca-se o fato de os artigos focarem a intervenção na formação de profissionais que atuam na inclusão escolar, isto é, a intervenção em como as pessoas efetivamente atuam no cotidiano escolar. Nesse sentido, Bastos e Kupfer (2010) relataram a experiência de condução de grupo para falar das dificuldades na escolarização de alunos inclusos. Freller (2010) refletiu sobre os limites e possibilidades de ensinar os professores a incluir alunos com dificuldades. Ferreira et al. (2009) relataram a prática de discussão com professores, enfatizando o seu papel no processo de escolarização. As competências que os profissionais devem apresentar para promover a inclusão escolar foram abordadas em Fabrício et al (2007). Esses dois aspectos foram tratados dentro de uma mesma perspectiva de formação continuada. Apenas o trabalho de Barbosa e Conti (2011) tratou de formação básica a respeito da inclusão escolar no nível da graduação.

Observa-se que a tendência nas teses consensuais da categoria é de que é possível promover atitudes favorecedoras da inclusão escolar por meio da formação do profissional. Por outro lado, essa categoria permanece focada na formação de professores. Apenas um trabalho, o realizado por Barborsa e Conti (2011), abordou a formação de outros profissionais envolvidos na questão da inclusão escolar. O estudo analisou a atuação do psicólogo escolar, sendo que, sem surpresa, trata-se de uma publicação oriunda de uma revista de psicologia escolar. 


\subsubsection{Discussão geral das categorias de publicações e conclusões.}

Nesse item, são apresentadas e discutidas as conclusões das categorias de publicações, em face da literatura internacional a esse respeito. Em seguida, realiza-se uma discussão geral em relação aos aspectos que essas categorias possuem em comum, referentes à questão da definição dos termos: inclusão escolar, educação especial e educação inclusiva. Na sequência, analisa-se o principal marco político utilizado para situar o contexto das pesquisas, as metodologias predominantes, os estudos realizados especificamente acerca da Paralisia Cerebral, o tipo de escola e a modalidade de ensino em que as pesquisas foram realizadas e a questão da aprendizagem da matemática. Posteriormente, é feita uma síntese sobre as principais teses dos artigos publicados e as filiações teóricas predominantes.

A síntese dos dados dessa revisão evidencia a complexidade que envolve a inclusão educacional e a prática escolar que a pressupõe. Três aspectos permearam todas as categorias: a relevância da consideração da subjetividade dos estudantes beneficiários da inclusão escolar, a aparente dicotomia entre as políticas públicas e a sua efetivação prática e a formação profissional, com ênfase particular no professor.

A maior produção, em termos de discussão teórico-conceitual a respeito da inclusão, tema da primeira categoria, denota a busca de solidificação da base teórica e paradigmática que a sustenta, o que pode ser observado também pela síntese dos artigos de revisões bibliográficas que foram incluídos nessa categoria. Todavia, diante dos dados dessa revisão, infere-se um entendimento comum sobre a necessidade de desfocar o aspecto neurológico e focar $\mathrm{o}$ aspecto psicológico e, portanto, o foco recai na subjetividade, conforme já vem sendo apontado, por exemplo, em Fávero e Salim (2001), como argumentado na fundamentação deste trabalho. 
Na primeira categoria está incluído o trabalho de Facci (2010), que identifica a importância da escola no desenvolvimento psicológico dos alunos e aponta a relação existente entre o conhecimento científico e o desenvolvimento das funções psicológicas superiores. Essa consideração, consoante com Fávero (2014), é particularmente relevante à medida que indica um caminho teórico que ultrapassa o antigo entendimento caritativo da inclusão escolar, ao mesmo tempo em que serve de pressuposto para a atuação profissional junto a crianças com necessidades educacionais especiais.

A persistência do desafio de práticas escolares que efetivem os pressupostos inclusivos, segundo aspecto consensual desta revisão, é um desafio discutido em âmbito internacional como, por exemplo, em Kurth \& Mastergeorge (2009) e Engelbrecht (2013). A menor quantidade de publicações em relação às práticas inclusivas pode representar uma falta de publicação de iniciativas exitosas ou a persistência da dificuldade de traduzir os pressupostos inclusivos em prática psicopedagógica no contexto da sala de aula. Esse fato está de acordo com a conclusão de vários estudos, tais como os de Ávila (2008), de Crochik et al. (2013), de de Gomes \& Rey (2007), de Jesus (2004), de Lourenço, Miranda e Póvoa (2012), de Oliveira e Leite (2011), de Silva \& Leme (2009) e de Veltrone \& Mendes(2011). Em Ricardo e Rossetti (2012) e em Tessaro et al. (2005), as questões da pesquisa se direcionam para alunos regulares que convivem com alunos inclusos. Em Ohl et al. (2009), foi realizado um delineamento de pesquisa utilizando um grupo de alunos com deficiência e um outro grupo de alunos sem deficiência. Nessa revisão, somente o trabalho de Montilha et al. (2009) focou exclusivamente em estudantes com deficiência, no caso do estudo citado, a deficiência visual.

Acerca da segunda categoria, foi possível observar um consenso em torno da necessidade de considerar a subjetividade das pessoas envolvidas no processo de inclusão 
escolar. Alguns trabalhos buscaram dar visibilidade às vivências dos alunos em relação à inclusão escolar. Todavia, como vimos na discussão dessa categoria, a maioria dos trabalhos focam os alunos regulares. Internacionalmente, por outro lado, a tendência é de dar voz nas pesquisas aos próprios estudantes inclusos, especialmente aqueles com maiores dificuldades, como apontam Lehman e Lava (2013).

A esse respeito, é ilustrativo o trabalho de revisão de literatura de Lundqvist (2014), que localizou pesquisas em contextos educacionais que incorporaram as respostas de crianças com ou sem deficiências ou necessidades educacionais especiais. As principais conclusões desse trabalho apontam para o benefício de oportunizar que a criança compartilhe sua opinião, o que produziria conhecimento sobre os contextos de aprendizagem baseados nas próprias experiências das crianças, trazendo benefícios também para elas próprias, como maior autoconfiança.

Outra conclusão possível, acerca dos trabalhos contidos na segunda categoria, foi a necessidade de abordar as crenças que subsidiam as práticas pessoais e institucionais acerca da inclusão escolar. Isso porque tais crenças baseiam e determinam as posições assumidas e as práticas pedagógicas.

Outro trabalho cujo resultado é notadamente relevante para o objeto de estudo da pesquisa desenvolvida no presente trabalho, é o de Rodrigues et al. (2012), que buscou compreender as concepções de professores sobre alunos diagnosticados com transtorno global do desenvolvimento ou autismo. Um dos resultados aponta que os professores entendem a ausência de padrão de desenvolvimento como o grande desafio da inclusão escolar. Isso denota a necessidade de ampliação da articulação entre educação e psicologia do desenvolvimento, de modo a possibilitar o aprofundamento de pressupostos teóricoconceituais que permitam aos profissionais da escola uma compreensão mais detalhada do 
desenvolvimento atípico. Ademais, pesquisas internacionais, como a realizada por Ahmmed (2013), apontam que o nível de suporte que os professores sentem que recebem, da comunidade escolar e da provisão de recursos de ensino apropriados e treinamento, pode influenciar suas atitudes para a inclusão.

Em relação às concepções dos estudantes, apesar de alunos com dificuldades serem mais rejeitados, houve relato de ganhos sociais para os estudantes que convivem com pares com deficiência. Tal resultado condiz com o trabalho de Almeida (2001) que, num estudo sobre as barreiras e facilitadores no processo de inclusão escolar de crianças com Paralisia cerebral, indicou que algumas atividades, quando realizadas de forma conjunta entre crianças típicas e crianças com Paralisia Cerebral, auxiliaram a socialização e a relação de troca entre os alunos, reduzindo possíveis estigmas ou preconceitos.

Sobre as concepções dos pais, a síntese possível é a de que, apesar de acreditarem nas proposições sobre a inclusão escolar, os pais observam aspectos a serem melhorados. Além disso, verificou-se a existência de divergências entre as expectativas dos pais em relação à aprendizagem de seus filhos e as expectativas dos professores desses alunos inclusos. Fato que se destacou foi a ausência de estudos que levassem em consideração aspectos demográficos e sociais - tais como classe social, raça e gênero - em interface com as concepções apresentadas pelos participantes em relação à inclusão escolar.

A terceira categoria, aquela que tratou da prática escolar inclusiva, trouxe o dado da percepção, ainda existente, de que as raízes das dificuldades escolares estão unicamente fora da escola. Esse entendimento parece relacionar-se com outro, que também foi discutido nas publicações, acerca da persistência da adoção do modelo médico em oposição ao psicológico. 
Nessa categoria, pode-se observar a presença de alguns artigos que relataram processos de intervenção com os alunos, o que é condizente com o entendimento de Almeida (2001), para quem a adoção de novos conceitos e estratégias também pode auxiliar o processo de inclusão na escola de ensino regular, por exemplo, com:

a adaptação de recursos, a construção de currículos adaptados, o estabelecimento de novas formas de avaliação, a preparação adequada dos docentes e o apoio da direção podem respaldar, de forma mais consistente, o processo de inclusão dessas crianças na escola. (Almeida, 2001, p. 210)

A preocupação com as práticas pedagógicas que sustentam o paradigma da inclusão escolar é compartilhada internacionalmente, como, por exemplo, no trabalho de Ghergut (2011). O autor trata da inclusão escolar na Romênia e afirma que exemplos de boas práticas existem, mas os modelos precisam ser reforçados e praticados mais sistematicamente.

Há uma defesa da necessidade do olhar combinado de diversas categorias profissionais para a inclusão escolar, embora predominem as abordagens centradas no professor, certamente por ser ele o profissional que mais comumente está na lida diária com estudantes inclusos. Todavia, o que chama a atenção é a ausência de estudos que centrem seu interesse primordial no desenvolvimento psicológico desse profissional.

Parece que a questão da formação profissional para a inclusão escolar tem sido um desafio maior que ocorre também além do âmbito brasileiro. Num trabalho realizado em Papua Nova Guiné, por exemplo, Rombo (2006) estudou barreiras à inclusão escolar e discutiu o papel do professor, já que suas atitudes são vistas como o maior elemento que pode tanto incluir como excluir crianças com necessidades educacionais especiais em escolas inclusivas. Por outro lado, Walton (2014) propõe a necessidade de um avanço a respeito da formação profissional, à medida que já se sabe da importância e das 
dificuldades da questão, então as pesquisas deveriam apresentar iniciativas no nível da formação inicial e continuada para prover a educação de professores para a inclusão.

Foi possível observar a coexistência de duas tendências acerca da definição da inclusão escolar, uma ampla e outra restrita. A primeira trata da inclusão escolar dentro do amplo espectro de inclusão social, oriunda do movimento sobre direitos humanos; a segunda diz respeito, mais especificamente, à relação entre diversidade humana e fracasso escolar. Nessa mesma linha de raciocínio, alguns autores debruçaram-se em abordar a diferença entre Educação Inclusiva, que é relacionada à igualdade de direitos, e a Educação Especial, que é alicerçada na questão das deficiências e limitações. Tal preocupação de diferenciação conceitual também é encontrada em artigos internacionais, sendo ilustrativo o trabalho de Chaabra (2010), oriundo de Botswana.

A Declaração de Salamanca foi largamente o marco político mais citado para contextualizar o entendimento sobe inclusão escolar. Ela foi utilizada na fundamentação teórica dos textos, o que é consistente com o observado na literatura internacional, conforme Chaabra (2010), Angelides (2011) e Bines (2011). Além dos textos teóricos, os trabalhos empíricos utilizaram questionários, entrevistas, relatos de caso e de experiência, análise do discurso e análise microgenética com abordagem teórica histórico-cultural, psicanalítica e de psicologia comportamental.

Apenas quatro trabalhos recuperados nessa revisão foram realizados com participantes com paralisia cerebral. Tal fato se destaca, visto que esse é o diagnóstico de alteração no Sistema Nervoso Central mais prevalente na infância (Bjorgaas, 2012; Distrito Federal, 2014). O trabalho de Ohl et al. (2009) apresentou narrativas de jovens com Deficiência Visual, Deficiência Motora e Paralisia Cerebral com e sem deficiência sobre sua trajetória escolar. Machado (2010) realizou um estudo em que foi investigado o efeito 
da prática de leitura a partir do ensino colaborativo sem, contudo, explicitar a implicação do diagnóstico apresentado pelo estudante em seu processo de aprendizagem.

Scorsolini-Comin e Amorim (2010) objetivaram investigar a corporeidade de crianças com esse diagnóstico, inclusas em escolas regulares. O conceito de corporeidade, utilizado nesse trabalho, comporta a noção que vai além da materialidade do corpo e considera ainda a noção de intercorporeidade, que destaca o "eu" e o "outro" como partes constituintes da mesma corporeidade. Cazeiro e Lomônaco (2011) investigaram a influência de atividades lúdicas na formação de conceitos por essas crianças. Seu trabalho problematiza que crianças com paralisia cerebral vivenciam a diminuição de oportunidades para experenciar algumas atividades cotidianas e lúdicas, comuns à maioria das crianças e que são fundamentais para o desenvolvimento de conceitos espontâneos. Os resultados apontaram que todos os participantes desenvolveram, pelo menos, um conceito.

A maioria dos trabalhos foi realizada em escola regular pública, no Ensino Fundamental. As pouquíssimas pesquisas realizadas nas etapas seguintes da escolarização podem ser entendidas como um reflexo do enfraquecimento do processo de inclusão nas etapas, como tem sido constatado e descrito na literatura. A constatação da necessidade de avançar com o processo inclusivo para as etapas finais da escolarização é encontrada em trabalhos de origem europeia, como, por exemplo, no caso da Itália, conforme descrito no trabalho de Begeny (2007).

Em relação à localização geográfica de produção das pesquisas analisadas, a maioria dos periódicos, que estão presentes nesta revisão, é do Estado de São Paulo, seguido de Minas Gerais e depois do Distrito Federal. Foi possível estabelecer algumas relações entre artigos publicados num mesmo periódico. 
Por exemplo, os artigos de orientação psicanalítica apresentam, de forma comum, uma preocupação com a consideração da subjetividade e da singularidade dos estudantes inclusos. Eles também se preocupam com a mobilização dos discursos profissionais, institucionais, científico e jurídico, em relação à inclusão escolar.

As publicações em revistas de orientação psicopedagógica mantêm em comum a preocupação com a inclusão escolar a partir de diferentes pontos de vista. Tais preocupações tratam-se, por exemplo: da necessidade de atualização e de reestruturação das condições atuais das escolas (Gomes, 2006); dos desafios da escola contemporânea diante dos problemas de aprendizagem e da inclusão (Travi et al., 2009); da atuação da psicologia na educação inclusiva (Gomes \& Souza, 2011); de questões da prática pedagógica (Machado \& Almeida, 2010; Barone, 2013); de expectativas e crenças de diferentes grupos a respeito da inclusão escolar (Cintra et al., 2009; Rocha et al., 2009); de representações compartilhadas pelos profissionais da educação quanto à situação de fracasso dos alunos (Gomes \& Souza, 2009a); da percepção e dos sentimentos vividos por professores e alunos com necessidades educacionais especiais (Barbosa \& Souza, 2010); dos aspectos organizacionais e institucionais que sustentam as dinâmicas escolares inclusivas (Gomes \& Souza, 2009b) e de características dos professores que possam garantir práticas inclusivas (Fabrício et al., 2007).

Os trabalhos publicados no periódico destinado exclusivamente à relação entre psicologia e educação apresentam teses que se complementam e podem ser consideradas ilustrativas para o momento em que vivemos em relação à efetivação dos pressupostos da inclusão escolar. Benedetti e Urt (2008) apontam que a estrutura escolar tem dificuldade em lidar com a diferença entre os alunos. Artioli (2006) aponta que, ainda que exista a proposta de inclusão escolar da pessoa com deficiência, não se pode considerar que ela 
venha de fato se efetivando. Por outro lado, Leite e al. (2011, p. 90) analisam que "estamos num momento de fomentar e apresentar dados decorrentes de pesquisas educacionais que envolvam práticas pedagógicas que favoreçam o progresso educacional dos alunos inclusos".

O conjunto das publicações, retiradas do periódico destinado à formação e atuação profissional, também pode ser considerado uma expressão do momento histórico a respeito da inclusão escolar. Silva e Leme (2009) investigaram o papel do diretor para a inclusão escolar; Dazzani (2010) defendeu o papel da psicologia escolar; Sekkel et al. (2010) quiseram identificar os determinantes para a construção de ambientes inclusivos; Gomes e Souza (2012) buscaram compreender as relações de subjetivação de professores no processo de inclusão escolar; Gomes e Rey (2007) exploraram as representações compartilhadas por profissionais da educação acerca da inclusão escolar; e Crochík et al. (2009) compararam os motivos de escolhas e rejeições de colegas dos alunos considerados em situação de inclusão escolar.

A discussão geral dessa pesquisa bibliográfica ajuda a formar o cenário no qual o objeto de estudo deste trabalho se insere e justifica sua pertinência. As discussões sobre a inclusão escolar envolvem diversos conceitos e posicionamentos de diferentes abordagens teóricas. A despeito da vastidão de olhares possíveis em relação ao tema, está posto o desafio de se pensar processos educativos que respondam às necessidades de alunos com as mais variadas características. Dentre esses, está o ensino e a aprendizagem da matemática.

Conforme citado na análise da terceira categoria, nessa revisão bibliográfica, apenas dois trabalhos, ambos realizados a partir da abordagem do paradigma de equivalência de estímulos, trataram da aprendizagem da matemática em interface com a 
inclusão escolar. (Rossit \& Goyos, 2009; Escobal, Rossit \& Goyos; Celso, 2010). Em nenhum deles encontramos uma definição explícita do que é que se trata quando falamos em conceito de número.

A conclusão de Chiesa e Fávero (2014) articula-se com a conclusão desta revisão bibliográfica, à medida que aponta a necessidade de estudos longitudinais e de intervenção, particularmente em relação às competências matemáticas, centrados no desenvolvimento psicológico de estudantes incluídos em escolas regulares, a partir de uma proposta que permita a evidenciação de seu desenvolvimento, seguindo o caminho já trilhado por Fávero e Salim (2001), Fávero e Vieira (2004) e Fávero e Pina Neves (2009). No contexto deste trabalho, a intervenção realizada refere-se especificamente ao conceito de número, sendo que este é um dos aspectos abordados a seguir. 


\subsection{Inclusão Escolar, Paralisia Cerebral e a Aprendizagem da Matemática}

O termo paralisia cerebral refere-se a um conjunto de alterações crônicas no desenvolvimento infantil, marcado por repercussão motora. A origem é neurológica (Martins, 2012), sendo a condição de disfunção neurológica mais comum da infância (Bjorgaas, 2012). A partir da apresentação clínica das alterações motoras primárias, podese classificar a Paralisia Cerebral como espástica, extrapiramidal, hipotônica, mistas e formas atípicas (Menkes \& Sarnat, 2000, conforme citado por Dellatolas et all. (2005). A Paralisia Cerebral espástica é, por sua vez, subdividida em hemiplegia, diplegia e tetraplegia. Na hemiplegia há presença de espasticidade no hemicorpo contralateral à lesão cerebral. A diplegia é tipicamente caracterizada por espasticidade bilateral nas pernas. A tetraplegia é a forma mais severa de acometimento e envolve tanto membros superiores como inferiores (Fennel \& Dikel, 2001, conforme citado por Delatollas, 2005).

Frequentemente, a Paralisia Cerebral é acompanhada de distúrbios sensoriais, dificuldades intelectuais, limitações na comunicação e alterações comportamentais. Não há avaliações psicométricas padronizados para a população com Paralisia Cerebral e, frequentemente, há prejuízo no desempenho em provas motoras e relacionadas ao tempo de execução de alguma atividade (French, 1987, conforme citado por Martins, 2012). Há evidências, na literatura, que apontam que crianças com Paralisia Cerebral apresentam dificuldades específicas em atenção, nas habilidades visuoespaciais e nas funções executivas, que se trata de habilidades referentes à autorregulação nos domínios cognitivo, comportamental e emocional.

Além disso, alterações da função perceptiva têm sido associadas à conceitualização da Paralisia Cerebral (Esben, 2003; Martins, Oliveira \& Amorim, 2008; Rosenbaum et al., 
2005). Como veremos adiante, o presente estudo mostrou que essas alterações da função perceptiva podem constituir-se um dado relevante em relação ao processo de escolarização de crianças com Paralisia Cerebral.

Com relação às hemiplegias, que são as lesões cerebrais unilaterais focais, sabe-se que podem causar prejuízos crônicos nas funções cognitivas processadas pelo hemisfério afetado (Kolk, 2001). Tem sido demonstrado que o lado da lesão cerebral é um importante fator preditivo para o perfil das desordens cognitivas apresentadas (Kolk \& Talvik, 2002).

Como se sabe, o conhecimento sobre a especialização hemisférica é proveniente de estudos de casos de lesões cerebrais que ocasionam uma desconexão inter-hemisférica. Desse modo, descobriu-se que o hemisfério esquerdo gerencia as funções de linguagem, destreza manual e atividade gestual, além de realizar procedimentos analíticos e sequenciais. O hemisfério direito é especializado nas funções da visão espacial, da atenção, do reconhecimento de fisionomias e no controle emocional. Procede de maneira simultânea e paralela (Gil, 2002). Desse modo, crianças com hemiplegia à esquerda, por exemplo, podem apresentar um padrão cognitivo que é caracterizado por déficits não verbais, como no caso das funções viso-espaciais, conforme revisão de literatura realizada por Freitas (2009).

Como dito anteriormente, não há avaliação psicométrica específica para a população com Paralisia Cerebral e quando esse tipo de avaliação é utilizada, o escore obtido na inteligência não verbal, reduzido em relação à inteligência verbal, é tomado como um indicador de prejuízo na percepção visual. Trata-se de questão controversa, já que os subtestes de inteligência não verbal acessam um complexo de habilidades cognitivas que são distintas de habilidades perceptuais visuais, segundo o trabalho de Stiers (2004), que concluiu que a percepção visual e o prejuízo na inteligência não verbal 
são déficits independentes em crianças com lesão cerebral (ver também Bottcher, 2010). Essa controvérsia e outras a respeito da Paralisia Cerebral trazem implicações importantes para a avaliação neuropsicológica, para a avaliação psicopedagógica e para a inclusão educacional.

Um dos aspectos que diz respeito a esta dissertação, refere-se aos estudos que apontam a prevalência de problemas de aprendizagem aritmética $(28 \%)$ como maior do que os problemas de linguagem (17\%) (Frampton, Yude, \& Goodman, 1998, conforme citado por Rooijen, 2014). Outros estudos defendem que, mesmo no caso de desenvolvimento intelectual avaliado como na média, o nível de desenvolvimento de crianças com lesão no Sistema Nervoso Central é atrasado em relação aos pares. No entanto, não há forte evidência de que esse atraso está relacionado à dificuldade de automatização de fatos numéricos (Jenks, 2008). Por outro lado, do ponto de vista da abordagem neuropsicológica, as habilidades precoces, como contagem e reconhecimento de quantidade, têm influência no desempenho acadêmico posterior, assim como a inteligência, a memória de trabalho e as funções executivas, além de habilidades cognitivas de domínio específico, como o senso numérico, a contagem, o subtizing e a memória visuoespacial (Bottcher, 2010).

As abordagens psicométrica e neuropsicológica nos estudos de Paralisia Cerebral se referem, prioritariamente, ao termo "déficit". Dessa forma, procurou-se, nos estudos, elencar informações sobre esses déficits, de modo que os resultados aparecem em termos de fatores como memória de trabalho, idade e linguagem da instrução e se relacionam de forma complexa com a resolução de problemas em matemática.

Da mesma forma, os estudos sobre assimetria da função manual e sua relação com o desempenho neuropsicológico de crianças com Paralisia Cerebral espástica, em processo 
de escolarização, evidenciam uma relação entre o prejuízo no uso da mão esquerda e dificuldades em habilidades visuoespaciais e visuomotoras. Um exemplo é o estudo de Dellatollas (2005), que utilizou atividade de contagem de quantidades discretas. Outro exemplo é o estudo de Rooijen (2010) que defende que o comprometimento do desenvolvimento de habilidades aritméticas em crianças com Paralisia Cerebral se deve à trajetória do seu desenvolvimento atípico por causa das limitações físicas em relação às experiências motoras. Pode-se, de forma geral, dizer que esses estudos não focam a prática de sala de aula.

Há duas vertentes no estudo do sentido de número. Ao explicar sobre uma dessas vertentes, aquela fundamentada na base inatista do desenvolvimento do senso numérico a partir de estudos com bebês e técnicas de habituação, Barbosa (2007) sobre os trabalhos de (Butterworth, 1999; Dehaene, 1997; Spelke \& Dehaene, 1999) afirma que a premissa de "que o desenvolvimento de conceitos numéricos envolve o movimento de acesso a conhecimentos matemáticos inatos localizados em módulo cerebral específico para números" (p. 184). A segunda vertente apontada pelo autor defende o sentido de número com base em habilidades cognitivas genéricas, através da apreensão contextualizada de conceitos e procedimentos lógicos-matemáticos, envolvendo números e quantidades, mesmo antes da formalização do ensino da matemática pela escola (Barbosa, 2007).

Neste trabalho, adota-se o embasamento teórico-conceitual e metodológico de Fávero (2014) para abordar o desenvolvimento de competências conceituais. Essa elaboração teórica-conceitual e metodológica nasce da articulação dos grandes teóricos de psicológica e de outras áreas, sendo um aporte interdisciplinar, para fundamentar o papel da interação social no desenvolvimento psicológico. Sendo assim, a autora faz questão de deixar clara a articulação entre as teorias, ressaltando o consenso sobre a importância da 
interação social:

Tanto do ponto de vista piagetiano, centrando o benefício no desenvolvimento cognitivo individual, como do ponto de vista vygotskyniano, focando o benefício da interação com um par em nível de desenvolvimento mais avançado que pode funcionar, portanto, como um tutor em relação à zona de desenvolvimento proximal. (Fávero, 2014, p. 328)

Nesse sentido, a autora considera que o mundo dos objetos e o mundo das pessoas constituem um só sistema, ou seja, o desenvolvimento psicológico se dá por meio de atividades desenvolvidas com os objetos, mediado pelas pessoas. Dessa forma, a autora explica que:

entender como se dá a construção do conhecimento envolve, muito mais do que saber como se constroem as estratégias cognitivas, envolve também a questão de como e quais são os valores sociais que permeiam as informações, os procedimentos e as próprias atividades. (Fávero, 2014, p. 328)

Assim, a autora propõe "a articulação entre os aspectos subjetivos, desenvolvimentais e cognitivos dos processos semióticos, num contexto psicológico e o fundamento histórico, institucional e ideológico dos sistemas de signos, num contexto sociocultural" (Fávero, 2014, p. 331). A Teoria dos Campos Conceituais, proposta por Vergnaud, conforme explica Fávero (2014), se articula com a sua perspectiva teórica apresentada anteriormente, a partir da própria definição de conceito, elaborada num tripé: o conjunto de situações que dão sentido ao conceito; os invariantes operatórios que estruturam os esquemas associados a tais situações; e as representações linguísticas e simbólicas que permitem representa-los. A Teoria dos Campos Conceituais é, dessa forma, uma teoria psicológica do conceito que permite:

1) identificar e estudar as filiações e rupturas entre diferentes conhecimentos do ponto de vista de seu conteúdo conceitual; 2) analisar a relação entre os conceitos tomados como conhecimentos explícitos e os invariantes operatórios que estão implícitos nas condutas dos sujeitos em situação e; 3) aprofundar a análise das relações entre significados e significantes. (Fávero, 2014, p. 342) 
Essa teoria sobre o desenvolvimento de conceitos, portanto, articula-se adequadamente com as concepções teóricas sobre o desenvolvimento psicológico, que foram abordadas anteriormente. Os principais aspectos de Fávero (1994, 2002, 2011, 2005 e 2012) serão retomados no final dessa fundamentação teórica. 


\subsection{Transição para a Vida Adulta}

Como a presente dissertação diz respeito a um adolescente incluso no ensino regular e, portanto, dentro de um processo que diz respeito à transição para a vida adulta, procuramos desenvolver, nesse item, alguns aspectos dessa transição. Vale ressaltar, em primeiro lugar, que encontramos apenas dois trabalhos específicos sobre essa transição em relação às pessoas com PC.

O primeiro trabalho, de Langerak (2013), nos auxilia no entendimento dessa escassez, uma vez que é explicada que a Paralisia Cerebral é vista como uma condição pediátrica, ao invés de uma condição de vida. Como esse estudo ressalta, os problemas enfrentados por adultos com Paralisia Cerebral podem ser explicados por uma falta de suporte durante sua transição da infância para a adolescência e para a vida adulta.

O segundo texto, de Galambos (2008), é o único em que encontramos a maturidade psicossocial na transição para a vida adulta de pessoas com deficiências. Sua tese é de há evidências que alcançar maturidade psicossocial durante a transição para a vida adulta é diferente para indivíduos com deficiência física, quando comparados aos pares saudáveis. Os principais argumentos de Galambos (2008) são os seguintes: 1- as ações de enfrentamento orientadas para a resolução do problema, para a fonte de estresse e a menor incidência de depressão são variáveis que contribuem para a maturidade psicossocial na transição para a vida adulta para pessoas com deficiências físicas; 2- a maturidade psicossocial é entendida como autonomia ou funcionamento independente 3- o funcionamento independente se relaciona com a produtividade, identidade ou autoconceito coerente, que, por sua vez, se relaciona à satisfação nos relacionamentos interpessoais.

O estudo de Galambos (2008) evidenciou que as variáveis como gênero, educação e severidade da deficiência não se mostraram significativas, enquanto que as variáveis 
familiares, como a superproteção, parecem dificultar o desenvolvimento psicossocial de pessoas com deficiência, mesmo nos casos em que a capacidade cognitiva é comprovada. Do ponto de vista comunitário, esse estudo revelou que fatores, como oportunidades de desenvolver relacionamentos sociais e encontrar emprego, foram mais associados com maturidade psicossocial para os participantes da pesquisa, pessoas com e sem dificuldades motoras.

No trabalho de Galambos (2008), entre as variáveis de maturidade psicossocial que teriam interferência na transição para a vida adulta, não se considera o desempenho acadêmico. Tal fato chama a atenção visto que subjacente ao conceito de maturidade psicossocial está o de independência, mas não há menção à independência financeira e o acesso ao mercado de trabalho é mencionado apenas como uma consequência da maturidade psicossocial.

Ainda sobre os resultados do trabalho de Galambos (2008), a maturidade psicossocial reflete aspectos de como as pessoas entre 18 e 20 anos, com Paralisia Cerebral, definem sucesso: ser feliz, autossuficiente, ter relações próximas com outras pessoas (King, Cathers, Polgar, MacKinnon, \& Havens, 2000, conforme citado por Galambos, 2008). A maturidade psicossocial pode refletir sucesso para pessoas jovens.

O resultado do trabalho de Galambos apresenta semelhanças com aqueles apresentados do estudo de Arnett (2001), que comparou critérios coletivistas e critérios individualistas, mostrando que os critérios individualistas eram os mais comumente considerados como marcadores de transição para a vida adulta, entre pessoas de diferentes idades. No estudo de Arnett (2001), mesmo algumas pessoas de meia vida responderam que não se consideravam adultas, o que poderia ser explicado pela natureza intangível e individualista das transições mais importantes consideradas por essas pessoas. Essa 
consideração, associada à anterior sobre o entendimento de jovens com Paralisia Cerebral sobre a maturidade psicossocial, é um aspecto merecedor de atenção visto que, muitas vezes, em decorrência de suas limitações físicas ou mesmo cognitivas, ou seja, da permanência da necessidade de cuidados, essas pessoas podem não alcançar esse ideal de independência, o que poderia trazer prejuízos afetivos tanto para si, como para seus familiares.

Dessa forma, retomam-se as discussões apresentadas nas sessões anteriores dessa fundamentação teórica e, contextualiza-se o conceito de inclusão escolar dentro do conceito mais amplo de inclusão social, o que está relacionado com os debates em torno da relação entre cidadania, empoderamento e sociedade (ver Fávero, Chiesa \& Freitas, 2015, no prelo). Nesse sentido, há uma tendência internacional de defender a consideração das vozes dos estudantes - student's voices - principalmente no que diz respeito às suas concepções sobre competências e dificuldades em relação às práticas escolares.

Vale ressaltar que a articulação teórica que vem sendo construída pela Prof. ${ }^{a} \operatorname{Dr}^{\mathrm{a}}$. Maria Helena Fávero há quase duas décadas e suas implicações metodológicas serão abordadas aqui por meio de alguns dos seus principais trabalhos. Em Fávero (1994) já estava posta a relação entre o processo de ensino-aprendizagem a as concepções subjacentes da interação entre ser humano e conhecimento, além do papel dos valores sociais que permeiam as informações, os procedimentos escolares e as próprias atividades.

Em Fávero $(2002,2011)$ é defendida a mudança do foco do modelo médico para um modelo psicológico para se compreender e estudar o desenvolvimento humano, considerando as peculiaridades do desenvolvimento de pessoas com necessidades especiais. Nesse sentido, o método de investigação é o procedimento de intervenção psicopedagógica, o que significa considerar a atividade mediada. 
"que permite o estudo das aquisições conceituais por meio da produção do sujeito, considerando-se a filiação entre competências e dificuldades, o que permite situar todo caso individual e, ao mesmo tempo, da análise dos processos mediacionais ocorridos na interação interpessoal, o que inclui o tipo de material utilizado e a natureza das atividades propostas" (Fávero, 2002)

Na publicação de (2005) a professora Maria Helena Fávero deixa claro a tese central de sua abordagem do desenvolvimento humano, que busca

"colocar em evidência as dinâmicas e os processos no estudo do desenvolvimento cognitivo, numa articulação entre os aspectos subjetivos, desenvolvimentais e cognitivos dos processos semióticos num contexto psicológico e o fundamento histórico, institucional e ideológico dos sistemas de signos num contexto sociocultural" (Fávero, 2005, p. 17).

Baseada nessa tese, essa autora propõe uma abordagem metodológica (Fávero, 2005, 2012) que será retomada na II Parte desse trabalho, para o desenvolvimento do estudo.

Tendo em conta essa fundamentação teórica, o presente trabalho se desenvolveu com o objetivo geral de pesquisar o processo de desenvolvimento de competências conceituais matemáticas de um aluno com paralisia cerebral, por meio de uma pesquisa de intervenção psicopedagógica. Para tanto, os objetivos específicos são: compreender as concepções do participante sobre seu histórico escolar, sobre escola, suas noções temporais e espaciais relacionadas ao cotidiano escolar, às relações sociais, às competências e dificuldades escolares, em especial em matemática; realizar avaliação psicopedagógica acerca do conceito de número desenvolvido pelo estudante e propor situações psicopedagógicas que propiciem o desenvolvimento do conceito de número e a compreensão do efeito relativo das operações nos números; composição e decomposição de números; reconhecimento da grandeza relativa dos números; compreensão do significado do número e suas operações; julgamento da razoabilidade dos resultados de cálculos mentais. 


\section{Parte II - O Estudo de Intervenção Psicopedagógica}

\subsection{O Problema e o Método}

Este trabalho buscou defender a necessidade de se estudar as peculiaridades do desenvolvimento de um estudante com Paralisia Cerebral para construir conhecimento que subsidie a prática escolar de educação inclusiva, conforme proposta de Fávero (2001). O estudo foi desenvolvido por meio de uma articulação entre pesquisa e intervenção, conforme proposto por Fávero (2002) e retomado por Fávero e Carneiro Soares (2002), Fávero e Oliveira (2004) e Fávero e Pimenta (2006). Isso porque, desse modo, se proporciona a ocasião para o sujeito desenvolver novos esquemas cognitivos, ao mesmo tempo em que coloca em evidência o processo desse desenvolvimento (Fávero \& Oliveira, 2004). Assim, o desenrolar da pesquisa ocorreu "em um contexto de dinâmica sociocognitiva entre pesquisadora e participante, considerando seus efeitos reguladores e como esses se integram ao processo de autorregulação próprio ao indivíduo" (Fávero \& Soares, 2002, p. 71).

A consideração da dinâmica sociocognitiva e seus efeitos reguladores se deu pela priorização da apresentação de situações-problemas nas sessões de intervenção psicopedagógica. Essa decisão metodológica articula-se com a fundamentação teórica deste trabalho, à medida que se associou interação social, a relação dialética entre aquisição conceitual e a capacidade de resolução de problemas (Fávero, 2009).

Assim sendo, para o planejamento, o desenvolvimento e a análise das sessões de intervenção deste trabalho, inspirado na articulação teórico-metodológica de Fávero (2009), buscou-se um procedimento para o estudo da relação entre competências e 
dificuldades escolares em matemática, no qual a resolução de situações-problemas foi entendida como instrumento de mediação de conhecimento, em uma situação de interação. Dessa forma, consideram-se as elaborações e regulações cognitivas do indivíduo, as interações e a relação entre as situações-problemas e como estas se relacionam a um campo conceitual específico.

As situações propostas e os materiais utilizados consideravam os dados obtidos na primeira avaliação e foram se modificando à medida que as sessões se desenvolveram. De toda forma, permeando essas escolhas, esteve sempre presente o entendimento sobre a importância da representação gráfica das atividades desenvolvidas.

Esse cuidado se deve pela consideração de que há funcionalidade na representação por dois motivos: "ela organiza a ação, o comportamento e, em geral, a atividade, sem deixar de ser o produto da ação e da atividade" e "ela permite certa simulação da realidade e, portanto, a antecipação" (Vergnaud, 2009, p. 59). Assim, por exemplo, foram utilizadas marcações no espaço para contagem de pequenas quantidades de objetos respondendo às características perceptuais relacionadas à Paralisia Cerebral. O foco das soluções de situações problemas foi, portanto, a representação, levando em conta a funcionalidade da representação como proposto por Vergnaud (2009), como já referido.

\subsection{O participante.}

Participou deste estudo um estudante com diagnóstico de Paralisia Cerebral, do tipo hemiplegia, nascido em 17/16/2000, tendo na época do estudo quatorze anos, capaz de se comunicar oralmente de forma inteligível e fluente. Filho mais novo de uma prole de dois, matriculado em escola pública regular, cursando o $6^{\circ}$ ano do Ensino Fundamental, residente no Distrito Federal. 
Segundo relato da mãe, ele frequentou a escola do ensino regular a partir dos três anos de idade,tendo sido indicado a repetência no Jardim II e $1^{\circ}$ ano do Ensino Fundamental. Do $3^{\circ}$ ao $5^{\circ}$ ano do Ensino Fundamental, ele estudou em escola privada em classe regular. Aos 11 anos de idade, ele foi submetido à avaliação psicológica que apontou deficiência intelectual,tendo sido recomendada adequação curricular.

Ele foi selecionado para a pesquisa pois numa situação de interação com a pesquisadora, relatou sua preocupação com o domínio das convenções de resolução das operações matemáticas. Daqui para frente, ele será chamado de G.

Após autorização para a realização da pesquisa pelo Comitê de Ética do Instituto de Humanidades da Universidade de Brasília, conforme Parecer Consubstanciado número 954.635, de relatoria em 19/02/2015, a família do participante foi contatada por telefone, quando foi feito o convite oficial de participação. As atividades de coleta de dados aconteceram nas dependências da Universidade de Brasília, Instituto de Psicologia, Laboratório de Psicologia do Conhecimento - COGITO, estando presente somente a pesquisadora e o participante durante todas as fases da pesquisa. Foi apresentado ao responsável o Termo de Esclarecimento Livre e Esclarecido e explicado sobre seu conteúdo (Anexo 1) e o Termo de Assentimento para G. (Anexo 2). Ocorreram dezessete encontros entre o participante e a pesquisadora, sendo as datas e os horários combinados diretamente com a família.

\subsection{Os procedimentos}

\subsubsection{Procedimentos de coleta de dados.}

A coleta de dados se deu através de quatro procedimentos: 1- uma entrevista semiestruturada; 2- a avaliação das competências e dificuldades sobre o conhecimento 
matemático; 3- as sessões de intervenção psicopedagógica, 4- a reavaliação das competências e dificuldades sobre o conhecimento matemático. A primeira fase foi constituída de uma entrevista semiestruturada com o participante, na presença dos responsáveis, que foi gravada em áudio. Os eixos da entrevista foram: concepções do estudante acerca de sua história escolar, concepções sobre a escola, noções temporais e espaciais relacionadas ao cotidiano escolar, relações sociais, concepções sobre sua escolaridade, competências e dificuldades escolares, em especial em matemática.

A avaliação psicopedagógica do conhecimento numérico constituiu-se como a segunda fase e, para tanto, foi utilizada uma adaptação da Épreuve Conceptuelle de Résolution des Problèmes Numériques - ECPN (Groupe Cimete, 1995, anexo 4). Trata-se de uma prova destinada a pessoas com dificuldade de aprendizagem em matemática, que explora as competências e dificuldades acerca do conceito de número, da lógica do sistema de numeração decimal e como as propriedades dessa lógica e desse conceito são utilizadas. Essa prova não depende do apoio em fatos numéricos memorizados ou do apoio na escrita.

As sessões de intervenção psicopedagógica constituíram a terceira fase. Elas foram planejadas com base nos dados obtidos na avaliação, isto é, na fase anterior. As atividades realizadas tiveram como objetivo propiciar o desenvolvimento nos aspectos evidenciados após a avaliação, ou seja, "mediar a reconstrução individual dos instrumentos culturais da aprendizagem e do pensamento, a partir da reestruturação das experiências pessoais" (Fávero \& Carneiro Soares, 2002, p.46). Dessa forma, a análise de uma sessão fundamentou o planejamento da próxima, inspirado no modelo de Fávero e Oliveira (2004).

As sessões de intervenção foram sistematizadas em termos de objetivos e descrição das atividades propostas. Foi realizada, também, uma análise minuciosa do 
desenvolvimento das atividades para cada sessão, explicitando: a sequência de ações do sujeito, o significado destas ações em relação às suas aquisições de estruturas conceituais, o tipo de mediação estabelecida entre o adulto e o sujeito, de acordo com o que propõem Fávero (2002) e Fávero e Oliveira (2004).

Os materiais utilizados nas sessões de intervenção psicopedagógica foram: folhas brancas do tipo A4, folhas de papel pardo, canetas hidrocor coloridas, lápis de cor variados, lápis grafite, cola branca líquida, palitos de fósforos, caixas de fósforos encapadas com papel branco, fita adesiva, calendário comercial de mesa - no qual cada mês foi apresentado em uma página - e relógio analógico. A quarta fase, aquela em que foi realizada a reavaliação das competências e dificuldades sobre o conhecimento numérico, seguiu o mesmo procedimento da segunda fase, a da avaliação psicopedagógica, e também contou com a utilização da Épreuve Conceptuelle de Résolution des Problèmes Numériques - ECPN (Groupe Cimete, 1995, Anexo 4).

\subsubsection{Procedimentos de análise dos dados.}

De forma compatível com a abordagem teórico-metodológica apresentada neste trabalho e considerando que se trata de uma pesquisa de intervenção psicopedagógica, que prioriza a interação entre a pesquisadora, o participante e o material utilizado em situações de resolução de problemas, as análises das interlocuções produzidas, em todas as fases da pesquisa, foram elaboradas segundo a proposta apresentada por Fávero (2005), elaborada a partir dos estudos de Chobral e Bromberg (1999) e retomada por Fávero (2007), Fávero (2012) e Pina Neves e Fávero (2012). Tal escolha deveu-se ao fato de que essa proposta permite, ao mesmo tempo, favorecer e evidenciar o desenvolvimento psicológico. Isso porque, como explica Fávero (2005), o conceito de atos da fala repousa basicamente no 
conceito de interação.

Os atos da fala produzidos nas interlocuções foram categorizados, de acordo com a adaptação realizada por Fávero e Abrão (2006, p. 176-177):

1) informação (todo ato da fala que visa descrever, categorizar, definir, considerar os objetos do mundo e sua relação de maneira não avaliativa); 2) avaliação (todo ato da fala que exprime um julgamento de valor, ou uma apreciação); 3 ) interação (todo ato da fala que visa à coelaboração das identidades dos parceiros e à cogestão das suas relações); 4) acional (todo ato da fala que propõe o fazer, que incita e exorta o fazer, o engajamento); 5) contratual (todo ato da fala que tem por função gerar ou regular a comunicação, em função dos objetivos, dos jogos de ações e do contrato de comunicação).

Para proceder à referida análise, as situações de interlocução entre a pesquisadora e o participante foram transcritas na íntegra, seguindo as normas de transcrição propostas por Oliver (2005) e Tian (2011). Esses autores destacam que, além dos princípios de transcrição e convenção, há que se refletir sobre decisões teóricas e metodológicas associadas com o processo de transcrição, que envolvem decisões de interpretação - o que será transcrito - e decisões de representação - como será transcrito. A opção para esta pesquisa foi a de transcrever as falas na íntegra.

As análises da segunda fase (avaliação das competências e dificuldades sobre o conhecimento numérico), da terceira fase (sessões de intervenção psicopedagógica) e da quarta fase (reavaliação das competências e dificuldades sobre o conhecimento numérico) tiveram como foco a relação entre competências e dificuldades do participante e a natureza das interações com a pesquisadora, conforme proposta de Fávero e Oliveira (2004). Nesse sentido, foram priorizadas as "sequências de ações do sujeito, seu significado em relação às aquisições de estruturas conceituais e o tipo de interação estabelecida" entre a pesquisadora e o participante (Fávero \& Pina Neves, 2011, p.102). 


\subsection{Resultados Obtidos em Cada Fase}

Nesta seção, são apresentados e discutidos os resultados de cada uma das fases de coleta de dados. Os dados de cada fase se relacionaram e fundamentaram o planejamento e o desenvolvimento das fases posteriores.

Na discussão dos resultados da primeira fase - a da entrevista semiestruturada - as concepções de G são apresentadas, acerca dos eixos temáticos que nortearam a entrevista, além da análise dos atos da fala, produzidos nas situações de interlocução.

Os resultados da segunda fase - a da avaliação das competências e dificuldades relacionadas ao conhecimento numérico - foram analisados segundo os critérios Prova ECPN (Groupe Cimete, 1995), tanto para a apresentação das questões como para a análise do significado das respostas. Foi elaborada uma tabela (Tabela 6) na qual se tem a informação de cada tarefa proposta pela prova, as respostas de $\mathrm{G}$ e a análise de seu significado.

A terceira fase do procedimento de coleta de dados diz respeito às sessões de intervenção de prática psicopedagógica. Foram desenvolvidas dezessete sessões e, para cada uma delas, são apresentados os objetivos, os materiais utilizados e o desenvolvimento. Na sequência, é apresentada uma discussão quanto aos resultados daquela sessão e as implicações para o planejamento da sessão subsequente.

A quarta fase da pesquisa, a de reavaliação das competências e dificuldades relacionadas ao conhecimento numérico, constituiu a décima sétima sessão de intervenção psicopedagógica. Nela foi utilizado o mesmo instrumento da segunda fase de coleta de dados, ou seja, a Prova Cimete (Groupe Cimete, 1995). Os resultados e a discussão desta quarta fase seguiram o mesmo modelo da segunda fase da pesquisa. Ao final da apresentação e da discussão dos resultados, segue-se uma sessão referente à discussão 
geral da pesquisa.

\subsubsection{O que narra a voz de G.}

Anteriormente, já mencionamos a tendência internacional em favor da consideração dos relatos dos estudantes (Fávero et al., 2015; Lehman \& Lava, 2013). Ainda nesse sentido, o trabalho de revisão de literatura de Lundqvist (2014) apontou para o benefício de oportunizar que a criança inclusa compartilhe sua opinião sobre seu processo de escolarização, de forma a produzir conhecimento sobre os contextos de aprendizagem baseados nas próprias experiências das crianças. Em suma, o que se quer defender é a adoção de procedimentos que permitam considerar, nas pesquisas, a subjetividade dos estudantes acerca de seu processo de escolarização.

No contexto deste trabalho, o estudo da voz do participante ocorreu na perspectiva de Fávero (2010) e retomado por Fávero et al. (2015). Isto é, o presente estudo contou com o respaldo teórico e metodológico da psicologia e pressupôs uma articulação interdisciplinar para a consideração da narrativa do self, considerando-a como a externalização da elaboração ativa do narrador (Fávero, 2010).

Assim sendo, as falas produzidas por G. na entrevista semiestruturada foram entendidas como uma externalização de sua elaboração ativa. Partindo da perspectiva de Fávero (2010), pode-se dizer que o procedimento utilizado para dar voz à G. criou uma situação favorável à externalização dos sentidos e significados internalizados por ele sobre suas competências e dificuldades na aprendizagem escolar da matemática (Fávero et al., 2015), o que pode ser entendido como a externalização da sua subjetividade. Os resultados sobre cada um dos eixos temáticos da entrevista são apresentados a seguir, seguidos da Tabela 5, com dados da interlocução entre a pesquisadora (P) e G. 
G. relatou detalhes sobre sua história de escolarização, descrevendo as diferentes escolas que frequentou, como as cores do uniforme e o logotipo da primeira escola, sem referência à relação entre as diferentes escolas e sua idade respectiva. Narrou quais eram as atividades que mais gostava, no início da escolarização, referindo-se às "conversas com os colegas" e ao "fazer o dever".

G. descreveu sua rotina cotidiana com conhecimento do dia e mês do seu aniversário, revelando noções básicas de tempo. Ele nomeou alguns meses do ano, mas não a sequência deles no ano. Narrou seu interesse particular por uma colega de escola e se utilizou de elementos de identificação de localidade espacial para fazer a avaliação de proximidade, demonstrando ter noções básicas de espaço em um espaço físico restrito: “ela mora no bloco perto do meu".

G. relatou também seu relacionamento com os colegas, referindo-se a brincadeiras e conversas, que ele adjetivou de "divertido", revelando uma posição de expectador: "Todo mundo fazendo bagunça. Gritava. Falando besteira pro outro. Eu fiquei rindo”. Ele relatou seu descontentamento com um colega, justificando que este imitava sua risada e descreveu sua iniciativa para solução da situação: "Reclamava para alguém. Reclamava com o meu colega e ele foi lá e ficou imitando minha risada e eu fiquei com raiva”. G. revelou seu interesse particular por uma de suas colegas e revelou que não quer que ela saiba, descrevendo o modo como tenta se aproximar dela, avaliando negativamente seu próprio desempenho: "Dou uma conversada sobre uns trequinhos lá. (...) Eu não converso muito porque eu não tenho muito papo com as meninas, não".

G. narrou seu desafeto em relação a uma professora que, segundo ele, o "vigiava" e explicou que isto se dava porque ele fazia "besteiras", descrito como "conversar demais". Assim, ao mesmo tempo em que tenta justificar seu desafeto, ele justifica o 
comportamento da professora atribuindo a si mesmo a causa deste último. Ele evidenciou ter conhecimento de que suas atividades escolares eram de natureza diferente das dos demais alunos, correspondendo à época na qual a adaptação curricular lhe era disponibilizada.

Em relação às competências e dificuldades escolares, em especial em matemática, notou-se que, ao descrever as atividades que menos gostava, G. usou verbos no passado e no presente na mesma afirmação em referência à aprendizagem de matemática: "Era ruim que eu não faço conta direito”. G. fez nova referência à matemática escolar quando descreveu sua primeira professora: "Eu gostava quando ela dava conta fácil". G. relatou que havia recentemente tido aula sobre retas, explicando com os seguintes termos: "tem a reta $\mathrm{AB}$, tem a reta $\mathrm{PQ}$, tem a reta $\mathrm{MN}$. E tem a reta $\mathrm{BC}$. Só lembro isso”. Ele também relatou que seu pai o auxiliava nas tarefas de casa.

G. aceitou a proposta de retomar uma das atividades não realizadas do caderno some 137 com o seu sucessor - utilizando os dedos para contagem, conferindo com o registro de risquinhos em uma folha de papel e obtendo o resultado correto. Retomando a atividade seguinte - some 298 com seu antecessor - ele reconheceu o antecessor: 297, colocando-o debaixo dos 298 e obtendo 585 como resultado da soma. Instigado pela pesquisadora, ele refez a soma e obteve o resultado correto: 595. Quando lhe foi sugerido comparar 585 e 595 ele afirmou que 595 era o maior e para saber quão maior, ele sugeriu: “tem que somar". Questionado se tal soma daria a diferença entre ambos, G. iniciou uma contagem nos dedos a partir de 586 até 594, não realizou a contagem até o fim e, em seguida, por sugestão da pesquisadora, recomeçou utilizando uma coleção de lápis para a contagem, iniciando novamente dos 586 e contando até 595. E afirmou: “dez!”

A Tabela 05, a seguir, apresenta a transcrição e a análise de um trecho da entrevista 
em que se pode observar as esferas dos atos da fala predominantes.

Tabela 5

Análise dos atos da fala retirados da entrevista semiestruturada

\begin{tabular}{lcc}
\hline \multicolumn{1}{c}{ Transcrição dos atos da fala } & $\begin{array}{c}\text { Esferas dos atos da } \\
\text { fala }\end{array}$ & Categorias dos atos da fala \\
\hline A: Isso aqui que você está passando (as & & \\
páginas). O que que tem aqui? (tarefa) & Informação & Informar \\
G: Conta de matemática. & & Informar \\
A: Que tipo de conta? & Informação & \\
G: Menos. & & \\
A: Você se lembra de como faz essa conta? & & Informar \\
G: (Balança a cabeça negativamente.) & \\
A: Então está bem. O que mais que tem aí & & \\
no seu caderno? O que é isso aqui, por & & \\
exemplo? & Informação & \\
G: Isso aqui são os números naturais. & & \\
A: Você sabe o que é isso? & & \\
G: Se eu sei? & & \\
A: É. & & \\
G: Número que.... Esqueci. & & \\
\hline
\end{tabular}

Assim como na análise desse extrato da entrevista, a dinâmica da interação entre a pesquisadora e G. se configurou basicamente dentro das esferas dos atos da fala de informação, que visa descrever, categorizar, definir e considerar os objetos do mundo e sua relação de maneira não avaliativa. Evidenciou-se também que a repetição da questão feita pela pesquisadora foi uma estratégia recorrente utilizada por G. e que, como veremos, se repetiu nas sessões de prática psicopedagógica.

\subsubsection{Avaliação psicopedagógica do conhecimento numérico.}

Para a avaliação do conhecimento matemático do participante, foi utilizada a Épreuve Conceptuelle de Résolution des Problèmes Numériques - ECPN (Groupe Cimete, 
1995, Anexo 4). O instrumento lida com pequenas quantidades distribuídas entre bonecos de madeira e, ao participante, é solicitado realizar algumas ações com as quantidades distribuídas entre os personagens, havendo, ainda, uma quantidade sobressalente à disposição para o uso do participante. A proposição das diferentes situações tem por objetivo que o participante invista suas competências em sua resolução e, ao mesmo tempo, que sejam evidenciadas eventuais lacunas conceituais. $\mathrm{O}$ material utilizado foi composto por três bonecos de madeira (um representando um avô, um representando uma avó e um representando um bebê), tendo sido dada a oportunidade ao participante de escolher quais bonecos utilizar; quarenta blocos de madeira, idênticos entre si e uma caixa reserva. A aplicação da prova, que levou 19 minutos, foi realizada seguindo a sequência apresentada no instrumento, gravada em áudio e vídeo e posteriormente transcrita na íntegra.

Os resultados obtidos estão apresentados na Tabela 6 que contém três colunas. A primeira delas traz a descrição dos sete itens que compõem a prova. Abaixo da identificação de cada item, entre parênteses, está registrada a função do número avaliado na prova (situação 1, 2 e 3: comparação de quantidades; situação 4 e 5: quantificação da relação de ordem; situação 6 e 7: pesquisa do estado inicial ou da transformação) e a apresentação da situação inicial das unidades, referentes a cada personagem. A segunda coluna traz a descrição das ações do participante, por meio de extratos da transcrição de sua interação com a pesquisadora. As ações do participante foram descritas entre parênteses. A terceira coluna traz a análise do desempenho do participante, imediatamente a frente do extrato de transcrição a que a análise se refere, com um espaço de separação entre o fim de um extrato e o início do próximo. Após a Tabela 6, há uma discussão sobre o desempenho do participante quanto aos conceitos avaliados e uma indicação do planejamento para a intervenção psicopedagógica, conforme Fávero e Oliveira (2004). 
Tabela 6

Descrição da prova ECPN, desempenho do participante e análise

\begin{tabular}{|c|c|c|}
\hline Descrição da tarefa & Ações do participante & Análise \\
\hline $\begin{array}{l}\text { Item } 1 \text { - Descrever a } \\
\text { situação } \\
\text { (Comparação) } \\
\text { Situação inicial: } 2 \text { vovó, } \\
3 \text { vovô, } 7 \text { bebê. }\end{array}$ & $\begin{array}{l}\text { G: O que é isso? Ah, tá, é para contar? } \\
\text { P: Eu vou te falar o que a gente vai } \\
\text { fazer. Então a gente tem a vovó, o vovô e } \\
\text { o bebê, certo? } \\
\text { G: Certo. } \\
\text { P: A gente vai chamar isso aqui de } \\
\text { blocos, tá bom? } \\
\text { G: Tá. } \\
\text { P: O que você pode dizer sobre como eu } \\
\text { distribuí os blocos? O que você acha? } \\
\text { G: (sem resposta) } \\
\text { P: Olha como eu distribuí. O que você } \\
\text { me diz disso? } \\
\text { G: (sem resposta) } \\
\text { P: Você viu o jeito que eu fiz? O que } \\
\text { você acha do jeito que eu distribuí os } \\
\text { blocos? } \\
\text { G: É... Bom? } \\
\text { P: Tem mais alguma coisa que você } \\
\text { acha? } \\
\text { G: Não, só isso mesmo. } \\
\text { Situacão final: } 2 \text { vovó } 3 \text { vovô } 7 \text { behê }\end{array}$ & $\begin{array}{l}\text { O participante não seguiu a tendência } \\
\text { esperada de utilizar estratégias de } \\
\text { contagem ou de estimativa perceptual } \\
\text { para estimar a quantidade, já que seu } \\
\text { comentário não tem relação com termos } \\
\text { numéricos. }\end{array}$ \\
\hline $\begin{array}{l}\text { Item } 2 \text { - Quem tem } \\
\text { mais } \\
\text { (Quem tem mais) } \\
\text { Situação inicial: } 2 \text { vovó, } \\
3 \text { vovô, } 7 \text { bebê. }\end{array}$ & $\begin{array}{l}\text { P: Quem tem mais blocos? } \\
\text { G: O bebê. } \\
\text { P: Como você sabe? } \\
\text { G: Tem um, dois, três, quatro, cinco, } \\
\text { seis, sete. Tem sete. } \\
\text { P: Então é o bebê que tem mais. Como }\end{array}$ & $\begin{array}{l}\text { Utilizou a contagem, conforme o } \\
\text { esperado, estabelecendo relação } \\
\text { biunívoca entre as duas coleções e } \\
\text { utilizando palavra-número ao final da } \\
\text { contagem, evidenciando o princípio da } \\
\text { cardinalidade. }\end{array}$ \\
\hline
\end{tabular}
você sabe?

G: Porque eu contei.

Situação final: 2 vovó, 3 vovô, 7 bebê.

Item 3 - Todos parecidos

Situação inicial: 2 vovó, 3 vovô, 7 bebê.
P: Minha pergunta é o que é que a gente pode fazer para que todos eles, o bebê, a vovó e o vovô tenham a mesma quantidade de blocos?

G: Colocar três aqui (apontando para a vovó) Colocar mais um aqui (ainda apontando para a vovó). Tem que tirar esses daqui (apontando para o bebê).

P: Então tenta fazer.

G: A mesma quantidade? (tira um do bebê e dá para a vovó e separa três do grupo do bebê). Esse outro para cá. E pronto.

P: E os blocos que sobraram a gente não vão usar?

G: É
Ele diz que tem que colocar mais três blocos com a vovó que já tem dois. $\mathrm{Na}$ sequência, corrige-se e diz que tem que colocar mais um.

Em relação ao bebê, que tem a maior quantidade de blocos, refere que tem que tirar.

A estratégia usada foi a compensação (pegar de um e distribuir para o outro e formar uma reserva) igualando todos a quantidade de três blocos para todos os personagens. 
P: Ah, foi uma boa ideia.

G: Um, dois, três, quatro, cinco, seis, sete, oito, nove.

P: O que é esse nove que você contou? G: Nove blocos.

Situação final: 3 vovó, 3 vovô, 3 bebês e três separados de todos os personagens.

Item 4 - "A mais que" a partir de estados iniciais diferentes (Quantificação da relação de ordem) a) Situação inicial: 3 vovó, 0 vovô, 7 bebê.

b) Situação inicial: 4 vovó, 4 vovô, 7 bebê.
P: Blocos, isso mesmo, mas eu queria que você fizesse alguma coisa para que $o$ vovô tivesse quatro blocos a mais que a vovó.

G: "Eita poxa". Um, dois, três, quatro. Pronto. O vovô tem quatro.

Situação atual: 3 vovó, 4 vovô, 3 bebê. G: Peraí. Um, dois, três. Conta tudo? P: Você quer que eu repita o que é para fazer?

G: Ah, pode ser, não entendi, não.

P: Vou repetir. Eu quero que o vovô tenha quatro blocos a mais que a vovó. G: Ah, quatro blocos a mais? Tem que colocar a mais do que isso?

P: Se precisar de mais tem aqui. Só se você achar que precisa.

G: Tá. É, tadinho, o bebê ficou sem. Nossa. Ê, vovô vai dar para você se divertir. Um, dois, três. Um, dois, três, quatro, cinco, seis, sete, oito, nove, dez. Deu dez.

P: Deu certo?

G: Deu.

P: O vovô tem quatro a mais do que a vovó?

G: Tem.

Situação final: 3 vovó. 10 vovô, 0 bebê

P: Eu queria que você fizesse alguma coisa para que o vovô tivesse um bloco a mais do que a vovó.

G: Eita. Me empresta aí, ô bebê. (pega um bloco do bebê e coloca com o vovô). Me empresta aí. Sem chorar (pega outro bloco). Chora não. Já vou te devolver (mais um bloco). Ele nem precisa chorar, eu já vou devolver para ele. Depois você
O participante conta a sequência de blocos de 1 a 9 , evidenciando o princípio da cardinalidade.

O participante conta quatro blocos do bebê e distribui para o vovô.

Conta os blocos da vovó e pergunta se é para contar tudo.

Foi sugerida a repetição do enunciado da tarefa e o participante afirma não ter entendido.

Diante da repetição da tarefa, o participante evidencia ter entendido o significado que "a mais que".

Após a pesquisadora oferecer blocos sobressalentes, caso necessário, o participante cria uma situação de interação simbólica com os bonecos e verbaliza com os bonecos.

Pega blocos do material sobressalente disponível e distribuí seis para o vovô.

Realiza uma contagem dos blocos da vovó e em seguida, conta os blocos do vovô. A contagem dos blocos do vovô foi feita considerando os quatro blocos que já estavam com o vovô, evidenciando noção de adição.

Mesmo após solicitação de conferência pela pesquisadora, o participante não modifica sua resposta.

Ele distribui os blocos tirando-os do bebê e colocando-os no vovô. Durante essa ação, ele verbaliza com o bebê. 
Item 5 - "Mais que" com "logro" numérico (Quantificação da relação de ordem) Situação inicial: 4 vovó, 7 vovô, 7 bebê.

\section{Item 6 - Pesquisa do estado inicial \\ (Pesquisa do estado \\ inicial ou da transformação)}

Início com quatro blocos escondidos brinca mais. Um, dois, três. Quantos a mais? Cinco?

P: Um a mais que a vovó.

G: Ah, tá. (coloca mais três). Um a mais que a vovó. Um, dois, três.

Um, dois, três, quatro, cinco, seis, sete.

Situação final: 3 Vovó, 7 vovô, 5 bebê.

P: Eu queria que você fizesse alguma coisa para que o bebê tivesse cinco a mais que a vovó.

G: Cinco a mais que a vovó. Tá. "Eita poxa”. Pegar os do velho também?

P: Se você quiser...

G: Quer dizer, vovô que é mais educado. G: Eita. (vai pegando blocos do vovô, um a um, e colocando próximo ao bebê, numa fila longa). Credo. Um, dois, três, quatro (do vovô). Um, dois, três, quatro, cinco, seis, sete, oito, nove, dez.

(contando os blocos do bebê).

P: Eu queria que o bebê tivesse cinco a mais que a vovó, deu?

G: Entendi. Cinco a mais. Colocar mais? (aponta vovô e o bebê).

P: Você que precisa ver o que fazer para ficar cinco a mais.

G: Um, dois, três, quatro, cinco, seis, sete, oito, nove, dez. (do bebê).

Onze, doze, treze, quatorze (pegando os últimos blocos do vovô).

\section{Situação atual: Bebê 14, Vovô 0 Vovó} 4.

P: Eu vou pegar um tanto de blocos aqui na minha mão, mas eu não vou falar para você quanto que é.

G: Tá.

P: Eu quero que você conte comigo quantos blocos eu vou colocar a mais na minha mão. Assim, eu tenho um tanto aqui escondido e vou colocar mais. Conta comigo quantos mais eu vou colocar.

G: Tá. Um, dois.

P: Vou juntar com o que eu já tenho. Agora, eu tenho seis blocos na minha mão. Quanto é que eu tinha no começo?

G: Dois?

P: É? Como você sabe?

G: Como eu sei?

P: É.

G: Sabendo.

P: Olha, conta aqui quanto eu tenho na
O participante questiona novamente qual era a tarefa.

Ele conta quantos cubos tem a vovó e o vovô.

Ele pergunta se pode utilizar os blocos de todos os personagens.

Redistribui pegando 3 blocos do vovô e colocando-os para o bebê.

Conta quantos restaram com o vovô.

Conta os blocos do bebê.

Ele diz que entendeu e, em seguida, questiona qual a tarefa.

Repete a contagem da quantidade de blocos do bebê.

Contagem a partir dos blocos do bebê juntando com os do vovô.

A distribuição final foi incorreta.

O participante não conseguiu engajar-se no raciocínio da transformação, em que um estado final é conhecido e é necessário achar o estado inicial desconhecido. Ele utilizou nenhum tipo de estratégia numérica para resolução. 
minha mão.

G: Um, dois, três, quatro, cinco, seis.

P: Seis eu tenho agora no final, depois que juntei tudo. Quanto eu tinha no

começo?

G: Três?

Item 7 - Transformação negativa

(Pesquisa do estado

inicial ou da

transformação)
P: Conta comigo quantas eu estou colocando aqui (mostrando palma da mão).

G: Um, dois, três, quatro, cinco.

P: Agora olha aqui. Eu fiz uma coisa sem você ver e agora tem três blocos aqui na minha mão. O que eu fiz? (retirada não visível)

G: Contou?

P: É? Vamos fazer de novo? Conta aqui comigo quantos blocos eu vou colocar na minha mão.

G: Um, dois, três, quatro, cinco.

P: Agora olha só o que eu vou fazer (retirada visível de dois cubos).

G: Tirou!

P: Tirei. Quantos eu tirei?

G: Dois?
O participante apresentou sucesso apenas na situação "mão aberta", ou seja, na situação não visível, o participante não opera uma transformação negativa, mas o faz em situação visível. 


\subsubsection{Discussão da avaliação psicopedagógica: competências e dificuldades de}

\section{$\boldsymbol{G}$}

Diante da tarefa do item 1, o participante não contou os blocos e nem fez uma estimativa geral. Um dos modos de explicar isso, segundo o instrumento utilizado, é o fato de que crianças com paralisia cerebral apresentam dispraxias visuoespaciais que poderiam causar dificuldade nesse item, especialmente por dificuldade no estabelecimento da relação biunívoca.

Na resolução do item 3, o participante criou um resto para igualar a quantidade de elementos de todos os conjuntos. Da ação de contagem realizada, pode-se observar que o participante evidenciou o princípio da cardinalidade, o que significa usar adequadamente um rótulo em contagem, e estabeleceu adequadamente a relação um-para-um, o que significa contar cada unidade apenas uma vez (Vergnaud, 1999). A capacidade de contagem, demonstrada nessa situação, contrasta com o desempenho do participante na situação 1, na qual ele demonstrou dificuldades que não apareceram na resolução da situação 3. Pelos dados obtidos, não é possível fazer afirmações sobre os demais princípios de contagem como a irrelevância da ordem, a ordem estável e a generalização.

No item 4a, o participante isolou duas informações da proposta de atividade e ignorou a terceira informação, justamente a que estabelecia a relação matemática entre as duas outras informações. A partir da repetição da tarefa, o participante demonstrou ter compreendido sua natureza aditiva, mas não teve êxito ao proceder à ação. No item $4 \mathrm{~b}, \mathrm{o}$ participante engajou-se numa brincadeira simbólica com os personagens e não utilizou nenhuma estratégia de contagem. Diante dos dados dos itens 3 , 4a e 4b, foi evidenciada a dificuldade de operar com conjuntos.

No item 5, o participante demonstrou capacidade de realizar a contagem 
convencional até o quatorze, mas não foi capaz de operar com os procedimentos exigidos para a resolução da situação, ou seja, um se aplicando a coleção menor e implicando uma soma e/ou outro se constituindo de uma medida da diferença.

Nos itens seis e sete, se apresentou uma transformação na quantidade de elementos e o participante deveria mentalmente realizar uma transformação inversa para descobrir o estado inicial da quantidade, exigindo-se assim, a reversibilidade do pensamento. G teve sucesso apenas na situação de transformação visível. Isto pode significar uma predominância do aspecto perceptual em relação ao aspecto cognitivo.

O desempenho apresentado pelo participante, nas provas do Épreuve Conceptuelle de Résolution des Problèmes Numériques - ECPN (Groupe Cimete, 1995, anexo 4), aponta para características que podem justificar suas dificuldades de aprendizagem escolar, visto que o conteúdo abordado na série em curso exige engajamento em raciocínios que ele parece ainda não ter desenvolvido.

\subsubsection{As sessões de intervenção psicopedagógica.}

Nesta seção, são apresentados e discutidos os resultados obtidos nas dezessete sessões de intervenção realizadas. Como sinalizado nos procedimentos de análise dos dados, para cada sessão são apresentados: a data de realização do encontro, a duração da sessão, os objetivos, os materiais utilizados, além do desenvolvimento, dos resultados e da discussão das atividades propostas. A análise dos resultados ocorreu por meio da descrição das ações do participante, do significado dessas ações em relação às estruturas conceituais e do tipo de mediação estabelecida entre a pesquisadora e o participante, conforme proposta de Fávero (2002) e de Fávero e Oliveira (2004). Dessa forma, a análise de uma sessão fundamentou o planejamento da próxima, de acordo com o proposto por Fávero e 
Oliveira (2004).

\subsubsection{Primeira sessão de intervenção psicopedagógica}

Data: 19-01-2015 Duração: 56 minutos

Objetivos: Propor situações que envolvam agrupamentos de quantidades discretas com base 10; propor situações de contagem de quantidades discretas; incentivar o engajamento em situações de estimativa perceptual e cognitiva; produzir registros gráficos referentes às atividades realizadas; incentivar a participação na resolução de problemas do campo conceitual das estruturas aditivas e multiplicativas.

\subsection{Desenvolvimento, resultados e discussão da primeira sessão de} intervenção psicopedagógica.

Esta sessão foi desenvolvida por meio de atividades de contagem e agrupamento de palitos em fileiras com base 10, sobre uma folha de papel pardo; estimativa perceptual de quantidade de palitos a serem contados; resolução de situações problemas envolvendo campo conceitual das estruturas aditivas e multiplicativas; registro com desenho da atividade realizada. Os materiais utilizados foram papel pardo, cola, palitos de fósforo, sacola plástica transparente, canetinha hidrocor, lápis grafite e folhas de sulfite.

A pesquisadora apresentou 80 palitos de fósforo dentro de uma sacola transparente, propôs a G. que contasse quantos palitos havia dentro da sacola e sugeriu que ele organizasse os palitos contados sobre a folha de papel pardo. G. dispôs quinze palitos um ao lado do outro na horizontal de forma ascendente, chegando próximo à margem superior da folha de papel pardo.

A pesquisadora sugeriu a organização de fileiras com 10 palitos e reorganizou os 
cinco palitos a mais da primeira fileira numa segunda fileira logo abaixo, com equivalência espacial entre as unidades. Ao concluir a segunda fileira de palitos, a pesquisadora solicitou que G. conferisse quantos palitos já tinham sido dispostos e demarcasse o ponto de início e de final da contagem. G. realizou a contagem, respeitando os princípios de relação biunívoca, ordem estável e cardinalidade.

Ao organizar a quarta fileira de palitos, porém, G. não estabeleceu relação espacial entre os palitos já posicionados nas fileiras anteriores, mas seguiu o tamanho das fileiras. Tais observações podem significar uma dificuldade de organização espacial.

Ao chegar na $5^{\text {a }}$ fileira de palitos, G. estava lidando com cinquenta e um palitos, mas referiu que a quantidade a ser organizada deveria ser cinquenta. A pesquisadora problematizou a situação da diferença entre a quantidade esperada e a quantidade que realmente estava organizada sobre o papel, sendo que G. propôs a retirada de um palito, realizando uma operação mental referente ao campo conceitual das estruturas aditivas.

Para conclusão da organização dos demais palitos, G. procedeu à contagem de conferência até 80, seguindo o princípio de relação biunívoca, corrigindo-se quando atingia, ao final de uma fileira, uma quantidade em sua contagem que não fosse múltiplo de 10, utilizando o mesmo procedimento descrito anteriormente, de operações mentais, com a mediação da pesquisadora, ou seja, subtraindo ou somando palitos para atingir um número múltiplo de dez. Isso demonstra vivências anteriores de G. com contagem em base dez.

A pesquisadora propôs uma situação-problema, referente ao campo conceitual das estruturas aditivas, envolvendo o conceito de "a mais" ou "quanto falta", questionando "o quanto 50 está longe do 80", em referência à quantidade de palitos que G. disse que acreditava que havia dentro da sacola e quantos palitos realmente havia. A resposta de G. foi "a dois números". Em seguida ele, verbalizou a sequência de dez em dez - “50, 60, 70, 
80" - e corrigiu sua resposta referindo "A três números". As respostas oferecidas por G. sugerem que ele operou com as dezenas, somando 10 unidades por 3 vezes ao 50. Apesar disso, sua resposta foi em unidades, o que denota uma dificuldade no conceito sobre a propriedade de valor posicional do sistema de numeração decimal.

Outra situação problema colocada pela pesquisadora diz respeito ao campo conceitual das estruturas multiplicativas, através da indagação sobre quantas vezes foram organizadas fileiras com 10 palitos. Como G. demonstrou não elaborar uma estratégia de resolução de forma espontânea, a pesquisadora optou por sugerir que G. circulasse todos os grupos de 10 palitos, visando mediar a compreensão da noção da multiplicação por soma de parcelas. Ela iniciou tal atividade e circulou duas fileiras, como exemplo. Ao perguntar para G. quantas fileiras já ele já tinha circulado, a resposta obtida foi 20 . Tal resposta pode ter sido oferecida pelo fato de haver o número 20 registrado com algarismos ao lado da segunda fileira, que havia sido registrado anteriormente para conferência de quantidade de palitos já organizada.

A pesquisadora retomou o objetivo da tarefa, que era o de circular todas as fileiras, sendo que G. procedeu ao contorno das demais fileiras com caneta hidrocor e, à medida que executava a ação, foi verbalizando a quantidade de grupos contornados. Mesmo assim, ao final dessa sequência de ações, G. teve dificuldade de retomar o raciocínio multiplicativo de quantas vezes foram formados grupos com dez palitos, confundindo a quantidade de palitos dispostos em cada fileira com a quantidade de fileiras organizadas. 
$\mathrm{Na}$ atividade de registrar o desenho da atividade do agrupamento dos palitos, $\mathrm{G}$. teve a preocupação de manter a equivalência entre a quantidade de palitos dispostos sobre a folha de papel pardo e a quantidade de desenhos a serem produzidos, como pode ser observado na Figura 1:

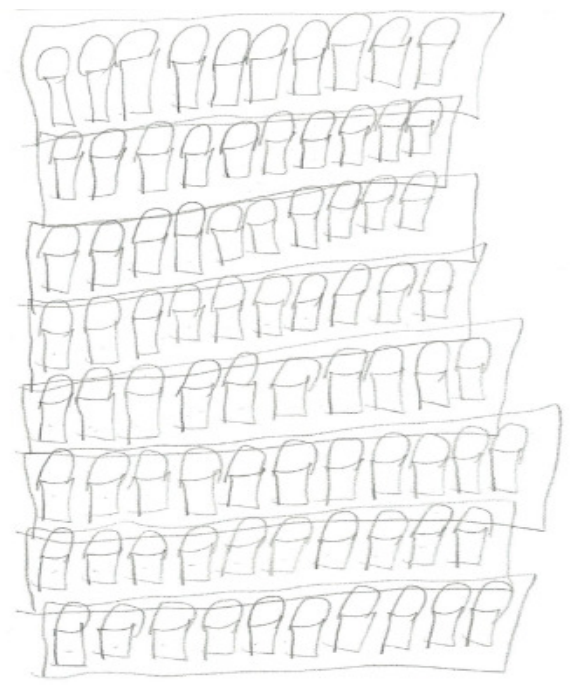

Figura 1. Registro da organização dos palitos em fileiras.

Foi possível observar, a partir dos dados dessa sessão de intervenção, que G. produziu agrupamentos dos palitos em base dez, como sugerido, realizou contagem de forma convencional tanto como forma de controle de quantidades como de sua conferência, realizou operações mentais de adição e subtração sem desagrupamento, engajou-se em situações referentes ao campo conceitual das estruturas multiplicativas através da soma de parcelas, ainda que tenha necessitado de apoio. Além disso, os dados apontam para a hipótese, já observada na seção 2.5.2 da avaliação do conhecimento numérico, de que G. apresentou dificuldades perceptuais que eventualmente o atrapalham no estabelecimento da relação biunívoca entre quantidades equivalentes, o que pode prejudicar outras competências relacionadas ao conceito de número e o próprio desempenho escolar. Esses 
aspectos serão retomados na próxima sessão de intervenção.

\subsubsection{Segunda Sessão de Intervenção Psicopedagógica.}

Data: 26-01-2015 Duração: 51 minutos

Objetivos: Incentivar e mediar o uso convencional do calendário; incentivar e mediar situações envolvendo os princípios de contagem de dias no calendário; incentivar e mediar situações de resolução de problemas, referentes ao campo conceitual das estruturas aditivas.

2.4.3.2.1 Desenvolvimento, resultados e discussão da segunda sessão de intervenção psicopedagógica.

Nesse encontro, foram realizadas as seguintes atividades de exploração do calendário: localização da data do dia corrente, data retroativa e prospectiva; situações de contagem de dias no calendário; situações-problemas envolvendo o campo conceitual das estruturas aditivas; retomada da atividade de organização de palitos, que havia sido realizada na semana anterior; registros de agrupamentos sucessivos com base 10. Foi utilizado um calendário de mesa, com cada mês representado em uma página, um lápis grafite, uma cola branca líquida e canetas hidrocor.

A retomada da atividade produzida na sessão anterior abriu espaço para a pesquisadora introduzir a exploração do calendário. G. soube dizer, de memória, a data do último encontro. Ele foi capaz de encontrar a data corrente (26 de janeiro), mas demonstrou que não domina todas as convenções do instrumento, como as siglas que identificam os dias e o direcionamento em colunas, para os dias da semana, apesar de nomeá-los na sequência correta. A pesquisadora sugeriu o uso do calendário para que fosse 
descoberto qual a data do encontro anterior, que havia ocorrido em 19-01. Visando auxiliar na compreensão da tarefa, a pesquisadora utilizou a expressão "a segunda para trás, que já foi”. A partir disso, G. oferece como resposta a data de 25 de janeiro, um domingo. Essa resposta sugere que G. operou com a contagem decrescente das datas, mas não o fez utilizando o conhecimento acerca da quantidade de dias que compõem uma semana.

A pesquisadora sinalizou que 25 de janeiro foi um domingo. Como já havia sido pontuado que os encontros entre a pesquisadora e G. ocorrem às segundas-feiras, G. modificou sua resposta, oferecendo como resposta a data de 5 de janeiro. Todavia, essa data estava circulada no calendário, sem relação com a sessão de intervenção, o que sugere que, nessa resposta, G. não utilizou as informações compartilhadas na sessão, buscando elementos externos, disponíveis no material em uso, para elaboração de sua resposta.

Dois tipos de conhecimentos estavam em jogo nessa situação: conhecimentos declarativos (nome, sequência e quantidade de dias que compõem uma semana) e conhecimentos matemáticos (sequência numérica e contagem crescente e/ou decrescente). Considerando situações anteriores em que G. demonstrou possuir tais conhecimentos, de forma isolada, essa dificuldade denota uma desarticulação entre os conhecimentos que G. já possui e sua utilização em situações de resolução de problemas.

Diante dessa hipótese, a pesquisadora ofereceu uma forma de resolução, demonstrando a G. que, para se descobrir uma data retroativa, se deve contar as datas para trás. Mesmo após a explicitação dessa forma de resolução, G. iniciou sua contagem a partir do dia 26, em ordem crescente. A pesquisadora repetiu a explicação, sendo que, assim, G. contou sete dias, retroagindo nas datas do calendário e encontrou o dia 19 de janeiro.

A pesquisadora inverteu a lógica da tarefa, sugerindo que descobrissem a data do próximo encontro. G. mostrou compreensão da ideia de futuro, mas novamente não 
utilizou o conhecimento sobre a formação das semanas e sua resposta para a data do próximo encontro foi "amanhã".

A pesquisadora retomou a composição da semana com sete dias. G. iniciou a contagem crescente dos dias, mas a interrompeu no dia 31 de janeiro. Ele percebeu que não havia completado a contagem em sete dias, mas não utilizou nenhuma estratégia relacionada ao uso convencional do calendário, como mudar de página, por exemplo. A resolução dessa situação ocorreu com a contagem simultânea da pesquisadora e de G., sendo que a primeira fez a ação de mudar de página ao acabar um mês e iniciar o outro.

Uma parte da explicação do desempenho G. nas atividades propostas pode ser um conhecimento parcial sobre o uso convencional do instrumento. Sobre isso, a proposta é retomar o uso do calendário, nas próximas sessões de intervenção. Vale ressaltar que ele faz uso de calendário digital no cotidiano, mas que apenas apresenta a data do dia corrente.

Na situação de retomada da atividade de organização de palitos, a produção de G. apresentou a mesma característica de organização horizontal ascendente, saindo da margem superior do papel pardo, como observada na Primeira Sessão de Intervenção Psicopedagógica. Conforme descrito na discussão da referida sessão, existe a hipótese de que uma dificuldade de organização perceptual atrapalhe G. na execução de algumas situações de contagem, especialmente quando os estímulos não estão distribuídos uniformemente no espaço.

Durante a colagem dos palitos já organizados nas fileiras, G. utilizou a contagem para a conferência da quantidade e para o estabelecimento da relação biunívoca entre os palitos de uma fileira e os que compunham a fileira imediatamente acima. A preocupação em manter essa relação entre os palitos de fileiras subsequentes foi verbalizada várias vezes ao longo do procedimento de colagem. G. utilizou de forma espontânea e adequada 
ao contexto o vocabulário referente aos numerais ordinais, relacionando-os ao posicionamento dos palitos nas fileiras.

Na situação de colagem de palitos, a pesquisadora propôs uma situação problema, referente ao campo conceitual das estruturas aditivas, do tipo "completando". Já haviam sido feitos quatro agrupamentos de 10 palitos e a pesquisadora questionou quantos agrupamentos ainda faltavam para chegar em 10 agrupamentos: "Para a gente chegar no 10 a gente vai precisar de mais quantos grupinhos?” A resolução dessa situação foi produzida com auxílio em quantidade discreta, com G. realizando contagem nos dedos, somando seis a partir de quatro, mas sua resposta foi de cinco agrupamentos. A partir dessa resposta, G. realizou uma estimativa perceptual de quantidade, argumentando que não seria possível formar 10 grupos, pois não havia palitos suficientes para tanto: "Cinco, seis, sete, oito, nove, dez. Vai precisar de mais cinco. Não, mais cinco não. É, acho que não vai dar não".

Ao concluir a colagem, a pesquisadora instigou G. a descobrir quantos palitos haviam sido colados. Sua primeira ação foi perguntar se ele deveria contar. A pesquisadora ofereceu uma resposta não diretiva a respeito, sendo então que G. engajou-se na contagem corretamente até 42. Porém, como as fileiras de palitos não foram coladas numa linha horizontal reta, ele contou palitos a mais do que os da respectiva fileira. A pesquisadora sinalizou que isso havia ocorrido e propôs que ele circulasse os grupos e seus respectivos palitos para facilitar a contagem.

Ressalta-se que a atividade, inicialmente proposta pela pesquisadora, sofreu alteração durante a execução, já que a mediação oferecida foi no sentido de circular a quantidade de grupos de cores diferentes e não apenas circular os grupos como havia sido a primeira proposta. Em alguns momentos, pela disposição dos palitos, como já mencionado, foi difícil para G. determinar se um palito em questão fazia ou não parte de um 
agrupamento, como pode ser observado na Figura 2.

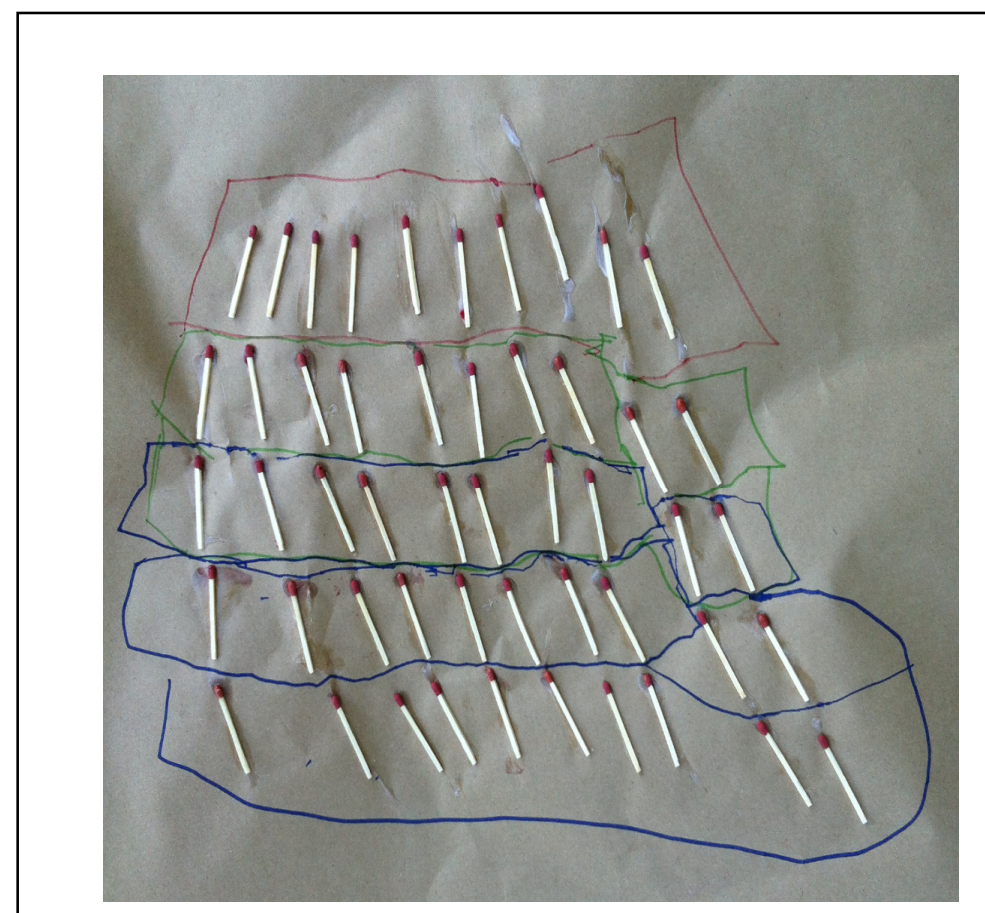

Figura 02. Colagem de palitos e agrupamentos circulados.

A impressão de que a disposição dos palitos estava atrapalhando o estabelecimento do agrupamento preocupou a pesquisadora. Desse modo, ela optou por encerrar a sessão para que pudesse realizar a reflexão e o planejamento das próximas sessões de intervenção. 


\subsubsection{Terceira sessão de intervenção psicopedagógica.}

Data: 02-02-2015 Duração: 64 minutos.

Objetivos: Incentivar o manuseio convencional do calendário e sua utilização para a resolução de situações problemas envolvendo noções temporais; produzir representação gráfica de agrupamentos com base 10; propor vivências de situações que envolvem o raciocínio multiplicativo, por meio de soma de parcelas.

\subsection{Desenvolvimento, resultados e discussão da terceira sessão de} intervenção psicopedagógica.

Quatro atividades foram realizadas nesse encontro: a manipulação do calendário e a resolução de situações problemas envolvendo noções temporais; a retomada dos agrupamentos com base 10 e sua representação; a transposição do registro feito com material manipulável (palitos) para o registro gráfico (desenho); a representação gráfica de novos agrupamentos com base 10. Como material de apoio, foram utilizados: um calendário de mesa, canetas hidrocor, cola branca líquida, palitos de fósforo colados em cinco fileiras com 10 unidades em cada fileira.

G. relatou de memória a data do dia e mês corrente, referindo que obteve esse conhecimento de seu relógio digital. Diante desse fato, a pesquisadora propôs a localização dessa data no calendário, sendo que G. o fez, sem apresentar dificuldades. A pesquisadora propôs a localização da data da última Sessão de Intervenção Psicopedagógica (26-012015), sendo que G. referiu essa data de memória. Infere-se que, como na sessão anterior essa data havia sido explorada, esse procedimento foi significativo para que G. retomasse a data em questão.

Em situação de localização dessa data no calendário, G. localizou corretamente o dia, 
mas não fez o retorno à página do mês correspondente, ou seja, apontou para o dia 26-022015. A mediação da pesquisadora foi no sentido de sugerir a busca de uma forma de encontrar a data do último encontro. G. demonstrou conhecer parcialmente o funcionamento do calendário como um suporte de representação do tempo, mas teve dificuldade em relacionar a sequência progressiva ou regressiva das páginas com o passar ou retroceder da representação do tempo, nesse caso, os meses. G. utilizou o verbo "voltar", denotando referir-se à noção de um tempo passado - mês de janeiro, já que a sessão ocorreu em fevereiro, mas teve dificuldade em relacionar esse conhecimento com o funcionamento convencional do calendário, a despeito da mediação da pesquisadora ao tentar auxiliá-lo na elaboração explícita do conhecimento já apresentado por G. Esse aspecto será retomado nas sessões posteriores.

Para a resolução da situação problema: "Faz quantos dias que a gente se encontrou?" a pesquisadora lhe auxiliou, estabelecendo o início e o fim do período a ser considerado, referente à data do encontro anterior e do presente encontro. G. demonstrou compartilhar da forma de resolução e propôs a realização de uma contagem. Todavia, nesse momento, confundiu-se no ponto final da contagem, realizando-a somente até o último dia apresentado naquela página, sendo que era necessário virar a página e continuar a contagem, já que houve mudança de mês entre a última sessão e o encontro presente.

G. apresentou dificuldade em operar também com a localização da data do próximo encontro. As respostas a essa situação foram de natureza alheia ao contexto da situação problema ou baseadas em marcações do calendário, como do feriado de Carnaval, ou ainda referente a dias da semana não correspondentes às segundas-feiras.

Infere-se que essa dificuldade tenha relação com a impressão de dificuldade na compreensão do funcionamento do calendário, como relatado anteriormente. A partir dessa 
impressão e da consideração, já mencionada, de retomar a manipulação do calendário em sessões subsequentes, a pesquisadora optou por não mais abordar esse assinto, nessa sessão, especialmente pelo fato de que G. apresentou sinais de fadiga.

Na situação de calcular "Quantos dias se passarão até a data do próximo encontro”, G. engajou-se na tentativa de realizar a contagem, mas não conseguiu explicar o que desejava contar, denotando desarticulação da realização do procedimento ao seu contexto de significação. Diante disso, a pesquisadora estabeleceu a data de início de fim da contagem, retomando a situação problema, que tratava da quantidade de dias, da presente data até o próximo encontro. Ao longo da contagem, G. ajustou o número falado ao número do dia registrado no calendário, violando o princípio da relação biunívoca e demonstrando predominância do estímulo visual, ao invés do controle mental da contagem.

A necessidade de explicitar o contexto da situação problema, como mencionado anteriormente, se repetiu na interlocução em que a pesquisadora questionou quantos dias restavam de férias ao estudante, ou seja, quantos dias até o retorno às aulas. G. engajou-se numa atividade de contagem, referindo estar buscando "saber o dia que eu vou voltar" para a escola. Nesse particular, a pesquisadora enfatizou que não buscava saber "qual" dia, mas sim "quantos" dias faltam para o início das aulas e apontou no calendário, com um gesto vertical as semanas que se passariam, desde a data presente até o dia 23-02, data do retorno ao período letivo. G., por sua vez, contou de um até quatro. O que se pode observar, é que o gesto da pesquisadora induziu G. a contar a quantidade de semanas referentes ao período de final de férias. Esses dados sugerem a necessidade de garantir que G. tenha compreendido a solicitação presente nas situações-problemas apresentadas e de evitar a sobreposição de situações e explicações, pois elas tendem mais a confundir do que a auxiliar seu desempenho. 
A pesquisadora direcionou a interação para a retomada da atividade do agrupamento de palitos e apresentou um novo registro de palitos organizados em cinco fileiras com 10 unidades em cada uma. Foi realizada uma conferência da quantidade de palitos agrupados em cada fileira para retomar o significado de cada círculo feito ao redor de cada agrupamento, assim como correções no traçado dos círculos para inclusão dos palitos faltantes. Em alguns momentos, foi necessário que a pesquisadora auxiliasse na contagem, delimitando fisicamente os palitos a serem contados como integrantes de um mesmo agrupamento de 10 unidades, escondendo os demais. A despeito da dificuldade de contagem, hipoteticamente provocada pela percepção, a atividade de agrupamento com base 10 e seu registro, realizados nas sessões anteriores, parecem ter sido significativos para G., visto que ele foi capaz de retomar as ações realizadas e seus sentidos.

Para a transposição do registro de palitos colados para o desenho, a pesquisadora solicitou a verificação de quantas fileiras deveriam ser desenhadas. A primeira resposta de G. foi oito quando, na verdade, no registro com palitos havia cinco fileiras. Isso pode ter relação com a primeira sessão de intervenção em que oito fileiras foram organizadas.

Quando lhe foi perguntado a respeito do total de palitos desenhados, G. realizou a contagem corretamente e optou por fazer uma anotação da quantidade contada, sendo que o fez em grupos de $10(10,20,30,40,50)$, sendo cada quantidade registrada ao lado de uma fileira, da primeira à quinta, respectivamente, conforme a Figura 3. 


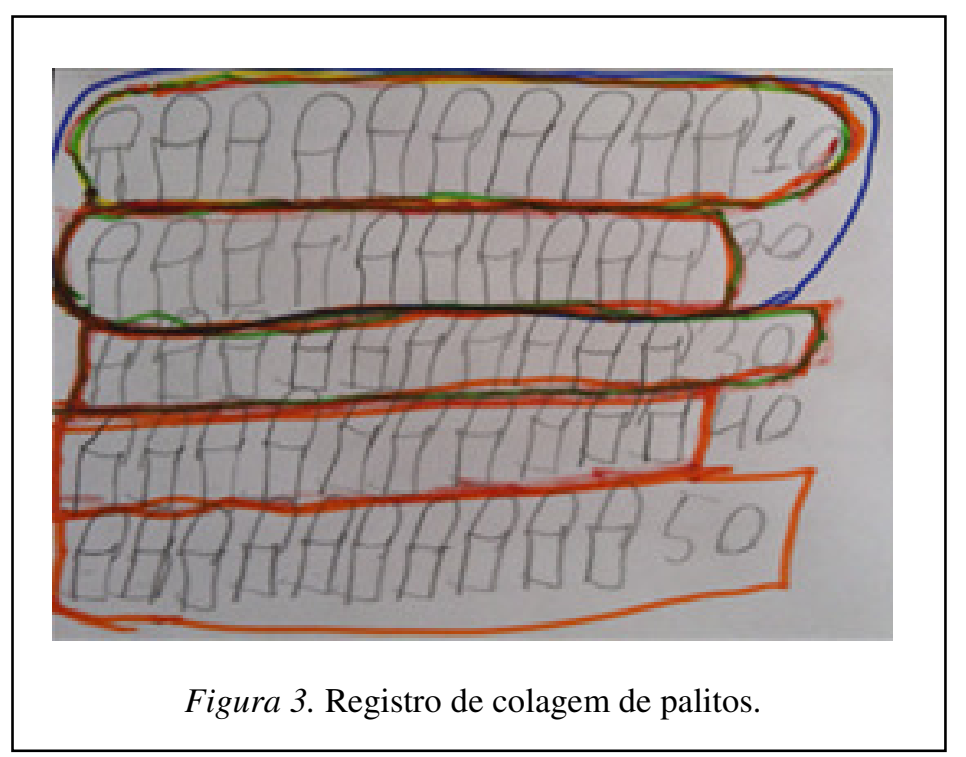

Entretanto, as interações seguintes denotaram que G. ainda não havia feito uma associação entre as quantidades representadas com algarismos ao lado das fileiras e o conceito de inclusão de classe, ou seja, que a quantidade 20, registrada na segunda fileira, se referia à soma da primeira e segunda fileira; que a quantidade 30 , registrada ao lado da terceira fileira, se referia à soma das três primeiras fileiras e assim sucessivamente. Como se pode ver na Figura 3, o traço feito em azul refere-se à mediação da pesquisadora que buscou explicitar esse conceito para G.

$\mathrm{Na}$ Tabela 7se percebe que ainda ocorreram situações de repetição da fala da pesquisadora em momentos que G. não apresentou uma reposta. Por outro lado, pode-se perceber também o engajamento em maior variedade de atos da fala, ocorrendo situações referentes à esfera de informação, ato da fala que visa descrever, categorizar, definir, considerar os objetos do mundo e sua relação de maneira não avaliativa. Ocorreram também situações referentes à esfera da avaliação, ou seja, ato da fala que exprime um julgamento de valor, ou uma apreciação e esfera acional, o que significa propor o fazer, que incita e exorta o fazer, o engajamento. 
Tabela 7

Análise dos atos da fala retirados da terceira sessão de intervenção

\begin{tabular}{|c|c|c|}
\hline Transcrição dos atos da fala & Esferas dos atos da fala & $\begin{array}{c}\text { Categorias dos atos da } \\
\text { fala }\end{array}$ \\
\hline \multicolumn{3}{|c|}{$\begin{array}{l}\text { Situação de contagem de palitos desenhados em fileiras com } 10 \text { elementos em cada uma, G. já havia contado } \\
\text { até } 20 \text {, e a situação, no momento, era definir quais elementos da próxima fileira deveriam ser contados para } \\
\text { alcançar a quantidade } 30 \text {. }\end{array}$} \\
\hline $\begin{array}{l}\text { G: Esses aqui. } \\
\text { P: Esses? Precisa de mais ou esses já são } \\
\text { suficientes? }\end{array}$ & Informação & Informar \\
\hline $\begin{array}{l}\text { G: Acho que precisa de mais. Um, dois, três, } \\
\text { quatro, cinco, seis, sete, oito, nove, dez, onze. } \\
\text { P: Precisa de mais ou não? } \\
\text { G: Precisa. } \\
\text { P: Onde a gente pode arranjar mais? } \\
\text { G: Um, dois, três, quatro, cinco, seis, sete, } \\
\text { oito, nove, dez. Onde pode arranjar mais? } \\
\text { P: É, para chegar ao } 30 \text {. }\end{array}$ & Avaliação & Avaliar \\
\hline $\begin{array}{l}\text { G: É...Desenhar? } \\
\text { P: Desenhar mais? } \\
\text { G: É. }\end{array}$ & Acional & Agir \\
\hline
\end{tabular}

\subsubsection{Quarta sessão de intervenção psicopedagógica}

Data: 22-02-2015 Duração: 28 minutos

Objetivos: Incentivar a compreensão e o uso convencional de calendário de mesa;

verificar a compreensão G. acerca das representações gráficas realizadas nas sessões anteriores; mediar situação de relacionamento de agrupamentos sucessivos de quantidades discretas com o raciocínio multiplicativo; realizar registro gráfico representando a multiplicação subjacente aos agrupamentos realizados.

2.4.3.4.1 Desenvolvimento, resultados e discussão da quarta sessão de intervenção.

A sessão foi iniciada com a retomada do período em que não houve encontros em função do feriado de Carnaval e de indisponibilidade de comparecimento por motivos 
pessoais da família de G. Nessa sessão, foram desenvolvidas quatro atividades de intervenção psicopedagógica. A primeira delas consistiu em situações de resolução de problemas de adição e subtração envolvendo noção temporal. A segunda atividade desenvolvida foi referente à retomada do registro gráfico realizado por G. e seu significado. A terceira atividade de intervenção foi a respeito do relacionamento dos sucessivos agrupamentos de palitos realizados com o raciocínio multiplicativo e a quarta atividade referiu-se ao registro gráfico do raciocínio mobilizado na terceira atividade.

Na primeira atividade realizada, G. demonstrou orientação temporal referente à data corrente, como já observado nas sessões anteriores. Não relacionou espontaneamente eventos de sua história de vida - cirurgia da mãe - e eventos de repercussão pública Carnaval - ao período em que não houve encontros.

A pesquisadora introduziu uma situação-problema, referente à quantidade de dias em que não houve encontros de intervenção, sendo que G. repetiu a pergunta feita. Esse comportamento foi observado sistematicamente nas sessões de intervenção e a impressão era a de que G. recorria a esse tipo de estratégia em situações em que não compreendia o enunciado apresentado pela pesquisadora.

Em face dessa hipótese, a pesquisadora ofereceu apoio à resolução da situaçãoproblema apontando a data da terceira sessão de intervenção e a data atual, visando auxiliar no estabelecimento do intervalo de unidades a serem contadas referentes ao período de dias em que não houve encontros de intervenção. A despeito disso, G. perguntou se deveria contar até o dia 23, denotando que ele ainda não havia compreendido a situação-problema. A pesquisadora insistiu em auxiliar no estabelecimento do intervalo de dias a serem contados, mas a dificuldade G. nesse tipo de situação ficou evidente quando ele realizou a 
contagem dos primeiros vinte e três dias do mês de fevereiro, quando deveria contar apenas o período compreendido entre o dia dois e o dia vinte e três.

A pesquisadora buscou auxiliá-lo nesse sentido, solicitando a confirmação da resposta dada e introduzindo uma interação que questionava o procedimento de contagem realizado G. Nesse momento, apareceu outra característica recorrente apresentada por G., nas sessões de intervenção, que é a de compreender esse tipo de interação como um indicativo de erro e alterar sua resposta, mesmo sem outra hipótese alternativa consistente.

Na resolução dessa situação, G. demonstrou que domina a sequência numérica, mas teve dificuldade em usar seus conhecimentos nessa situação envolvendo o uso do calendário, fato que causou um conflito cognitivo em relação à necessária descentração do material concreto em função do procedimento de contagem. Ou seja, G. deveria iniciar a contagem falando o número "um" em referência ao dia identificado com o algarismo "dois". Mesmo com apoio da pesquisadora apontando os dias a serem contados, ao longo do procedimento, G. regularizou sua fala ao número do dia apresentado no calendário e continuou a contagem, chegando à quantidade vinte e três, mesmo após o término do apontamento. Isso indica que G. não compreendeu que vinte e três referia-se à data do encontro vigente e não ao resultado esperado à sua contagem. Além disso, o estímulo presente no material concreto foi preponderante aos princípios de contagem que G. utiliza corretamente em outras situações.

A pesquisadora lançou mão de outra estratégia de mediação, oferecendo a possibilidade de circular as datas inicial e final, delimitando, dessa forma, o período de dias a serem contados. Mesmo assim, a dificuldade de descentrar-se do material concreto prevaleceu, até que a pesquisadora optou por explicitar a necessidade de chamar o dia dois 
de fevereiro de "um" para iniciar a contagem. Diante dessa estratégia de mediação, G. conseguiu realizar a contagem de forma apropriada à situação-problema apresentada.

Visando averiguar qual a compreensão que G. estava apresentando da situação vivenciada, a pesquisadora perguntou qual a razão da quantidade de dias contados não coincidir com a quantidade vinte e três. G. remeteu-se à data em que não houve encontro em função do feriado para explicar essa diferença.

Tal resposta, associada com as observações discutidas anteriormente, podem ser uma indicação de que, em função da prevalência da percepção dos estímulos do calendário, G. teve dificuldade em seguir os princípios de contagem referentes à irrelevância da ordem de contagem de generalização. $\mathrm{O}$ primeiro deles diz respeito à consciência de que os objetos podem ser contados de qualquer jeito sem que isso altere o resultado da contagem, e o segundo refere-se à consciência de que o conjunto de princípios de contagem (ordem estável, irrelevância da ordem, cardinalidade e correspondência biunívoca) são usados para contar qualquer conjunto, seja ele composto de objetos, ações ou sons.

Além disso, destaca-se o fato de que G. apresentou dificuldade de descentração do estímulo presente no material concreto - calendário - para considerar cada dia uma unidade de contagem, a despeito da representação daquela unidade. O desempenho apresentado G. nas sessões de intervenção anteriores, em que ele não apresentou dificuldades de contagem quando o material a ser contado era composto por unidades discretas sem representações simbólicas associadas, reforça essa hipótese.

G. demonstrou conhecer a sequência convencional dos meses do ano e chegou à conclusão de que existe uma relação entre essa sequência e a mudança de páginas no calendário, após manipulá-lo, em conjunto com a pesquisadora. A segunda atividade realizada, nessa sessão de intervenção, tratou da retomada do significado dos registros 
realizados nas sessões anteriores. G. compreendeu que os registros gráficos (Figura 3) produzidos são representações da colagem de palitos (Figura 2). Para G., os palitos foram organizados em fileiras para se alcançar a quantidade 10 e os círculos ao redor de cada fileira servem para delimitar cada agrupamento. Foi necessário que a pesquisadora esmiuçasse com perguntas acerca de cada um desses elementos, já que G. ofereceu respostas parciais e sucintas.

G. fez referências aos números registrados ao lado de cada fileira (Figura 3) e quando questionado acerca da representação física de sua quantidade, ele inicialmente teve dificuldade em relacionar a soma das unidades de cada fileira com a quantidade representada. A mediação da pesquisadora nesse sentido foi a de sugerir que G. utilizasse a contagem para conferência. Após tal proposta, G. conseguiu engajar-se em raciocínio referente à quantidade de fileiras necessárias para alcançar uma quantidade como, por exemplo, três fileiras contêm trinta unidades.

Quando se engajou em atividade de contagem e não considerou todas as fileiras necessárias para alcançar a quantidade solicitada, G. percebeu o equívoco e corrigiu-se. Em uma situação em que era necessário alcançar a quantidade quarenta e a contagem resultou em trinta e nove, G. percebeu o equívoco sem mediação e criou a hipótese da falta de contagem de uma unidade.

A esse respeito, salienta-se a mudança de postura da pesquisadora que, nas sessões anteriores, antecipava-se a G.com a repetição da solicitação, diante de uma resposta equivocada ou da ausência de resposta. Nessa sessão, entretanto, a pesquisadora permaneceu em silêncio em alguns desses momentos, o que deu oportunidade para G. autocorrigir-se. 
Nessa situação de intervenção, também pôde ser observado que G. se engajou em uma situação que envolvia o raciocínio multiplicativo, a partir da soma de parcelas, interagindo com a pesquisadora na situação em que ela citava a quantidade de linhas e ele respondia a quantidade de elementos correspondentes. Naquele momento, a pesquisadora propôs a quarta atividade psicopedagógica dessa sessão, que consistiu em realizar um registro da situação anteriormente vivenciada. Em seu enunciado, ela utilizou a palavra "escrever", o que fez com que G. compreendesse a necessidade de produzir um registro com palavras. Diante disso, a pesquisadora reformulou seu enunciado, buscando direcionar a ação de G. para o registro de notações numéricas e, solicitou que ele representasse quantas vezes cada linha com 10 elementos foi registrada.

G., por sua vez, relacionou tal situação com a operação convencional da multiplicação, citando fatos numéricos memorizados e procedendo ao registro das notações. A pesquisadora traduziu em palavras cada registro realizado e ambos permanecem nessa interação até a conclusão do registro, conforme mostra a Figura 4.

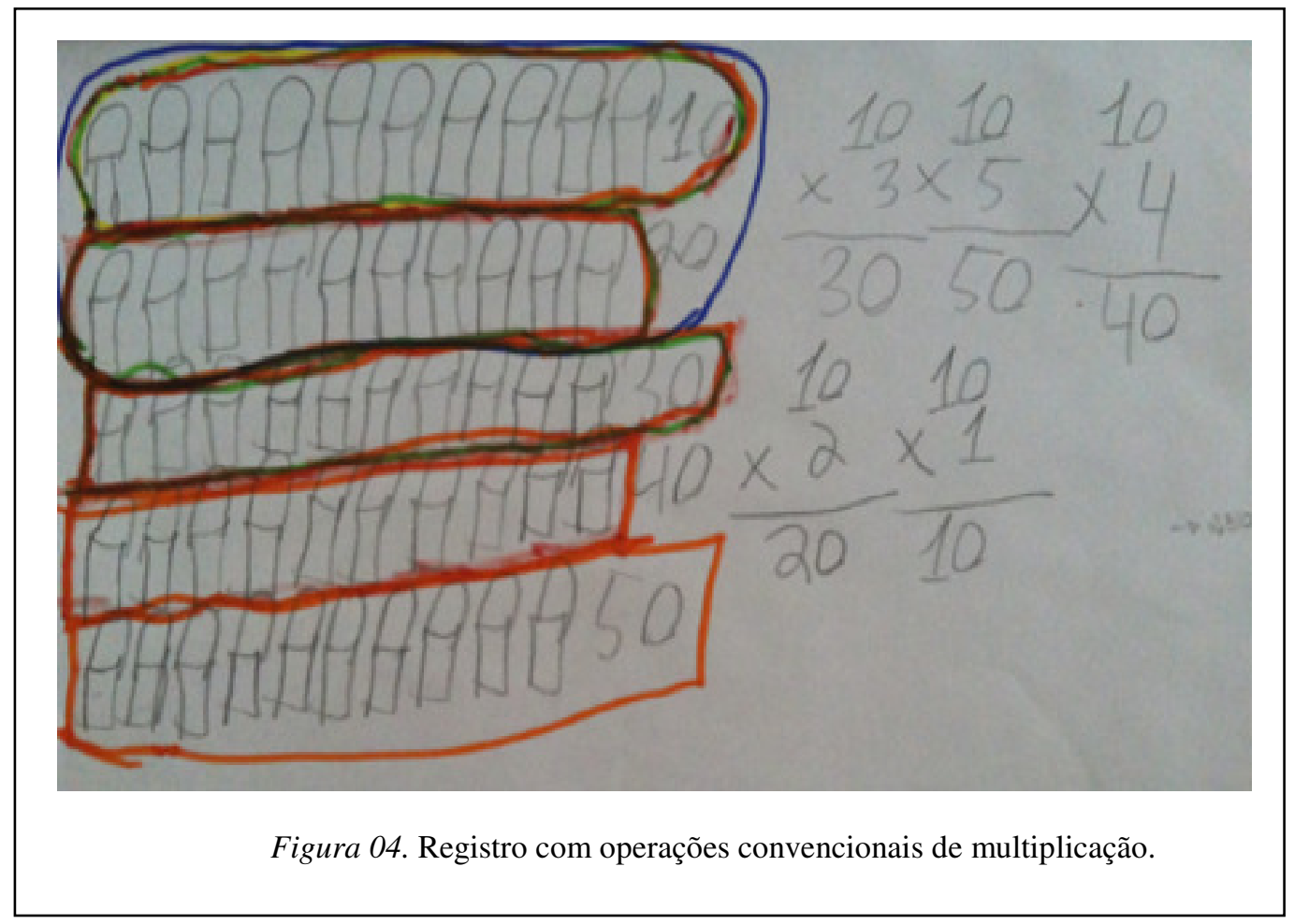


Diante do exposto, pode-se observar que G. já havia sido submetido ao ensino formal da operação da multiplicação, dominando seu registro e fatos numéricos referentes à tabuada do 10. Entretanto, parece só ter havido tomada de consciência da relação entre a operação convencional e a organização das quantidades a partir da interação com a pesquisadora.

Para a sessão seguinte, a proposta foi avançar na representação das quantidades, chegando à centena. Era esperado que G. conseguisse seguir no raciocínio que fora mobilizado com quantidades maiores. 


\subsubsection{Quinta sessão de intervenção psicopedagógica.}

Data: 09/03/2015 Duração: 45 minutos

Objetivos: Aumentar a quantidade de unidades discretas usadas durante a sessão; avaliar se G. lida com maiores quantidades mantendo ou não características observadas nas sessões anteriores; propor situações que envolvam o campo conceitual das estruturas aditivas com quantidades até 100; incentivar o manuseio convencional do calendário e do relógio; avaliar e incentivar a utilização de calendário e de relógio para a resolução de situações-problemas envolvendo noções temporais; incentivar o manuseio convencional do calendário e sua utilização para a resolução de situações-problemas envolvendo noções temporais.

2.4.3.5.1 Desenvolvimento, resultados e discussão da quinta sessão de intervenção psicopedagógica.

Nessa sessão foram desenvolvidas duas atividades. A primeira delas diz respeito à manipulação do calendário e do relógio para a resolução de situações-problemas e para a produção de registro gráfico e a segunda atividade diz respeito à apresentação de 100 unidades discretas e à exploração de situações-problemas do campo conceitual das estruturas aditivas, além da produção de registro gráfico. Para a realização das atividades, foram utilizados: um calendário de mesa, um relógio analógico, o registro de organização de palitos distribuídos em cinco fileiras, com 10 unidades cada fileira, folha sulfite, lápis grafite.

Na primeira atividade desta sessão, G. expressou consciência temporal sobre a data do dia. Quando em situação de manipulação do calendário, relacionou o retroceder das páginas do calendário com a sequência inversa dos meses do ano. Conjectura-se, a esse 
respeito, que tal conhecimento tenha relação com a última sessão de intervenção em que tal aspecto foi abordado.

Na situação de calcular "a quantos dias havia começado suas aulas", G. elaborou sua resposta baseado na marcação do calendário feita em cor diferente para representar o fim de semana ao invés de utilizar um procedimento matemático. Tal estratégia demonstra, por um lado, uma busca de resolução baseada em elementos disponíveis no próprio material em uso e, por outro lado, uma dificuldade em compreender a situação-problema como uma questão de matemática.

Durante a manipulação do relógio, pôde-se perceber que G. reconheceu as diferentes funções dos ponteiros, mas não realizou a representação da hora como um inteiro, com base 60, e os minutos e segundos como suas frações. G. demonstrou conhecimento empírico a respeito desse assunto ao se referir que, em seu relógio, as horas mudam ao chegar em 59 minutos. Demonstrou familiaridade com a representação gráfica convencional das horas e minutos, mas de forma ainda fragmentada, pois tinha dúvidas sobre os segundos. Nas sessões seguintes, o calendário e o relógio poderiam ser utilizados para a abordagem dos números inteiros de decimais.

O início da segunda atividade, daquela sessão, foi realizado por meio da indagação sobre o significado das operações de multiplicação registradas na sessão anterior (Figura 4). G. relacionou a realização de tais operações com a busca de uma quantidade e não como a representação da colagem dos palitos. O mesmo foi observado em relação às parcelas que compunham a operação.

A partir dessa impressão, a pesquisadora buscou auxiliar no estabelecimento da relação entre as operações de multiplicação realizadas e a colagem dos palitos. O início da tomada de consciência G. a respeito dessa questão pode ter sido expressado no seu 
questionamento se "vezes", palavra utilizada pela pesquisadora, significava multiplicação. A pesquisadora continuou com a mediação a esse respeito, propondo uma leitura compartilhada dos multiplicadores das operações, ao mesmo tempo em que os relacionava à quantidade de fileiras de palitos coladas.

A pesquisadora apresentou uma nova organização de palitos desenhados numa folha, semelhante ao produzido por G. e sugeriu a união de ambos os grupos. G. disse que, dessa forma, aumentaria a quantidade de palitos e optou por realizar uma contagem somando todos os palitos de ambos os grupos para aferir a quantidade total. Desse modo, ele demonstrou, como o esperado, o reconhecimento do efeito das operações nos números, sendo essa uma das compreensões desejadas para o sentido de número.

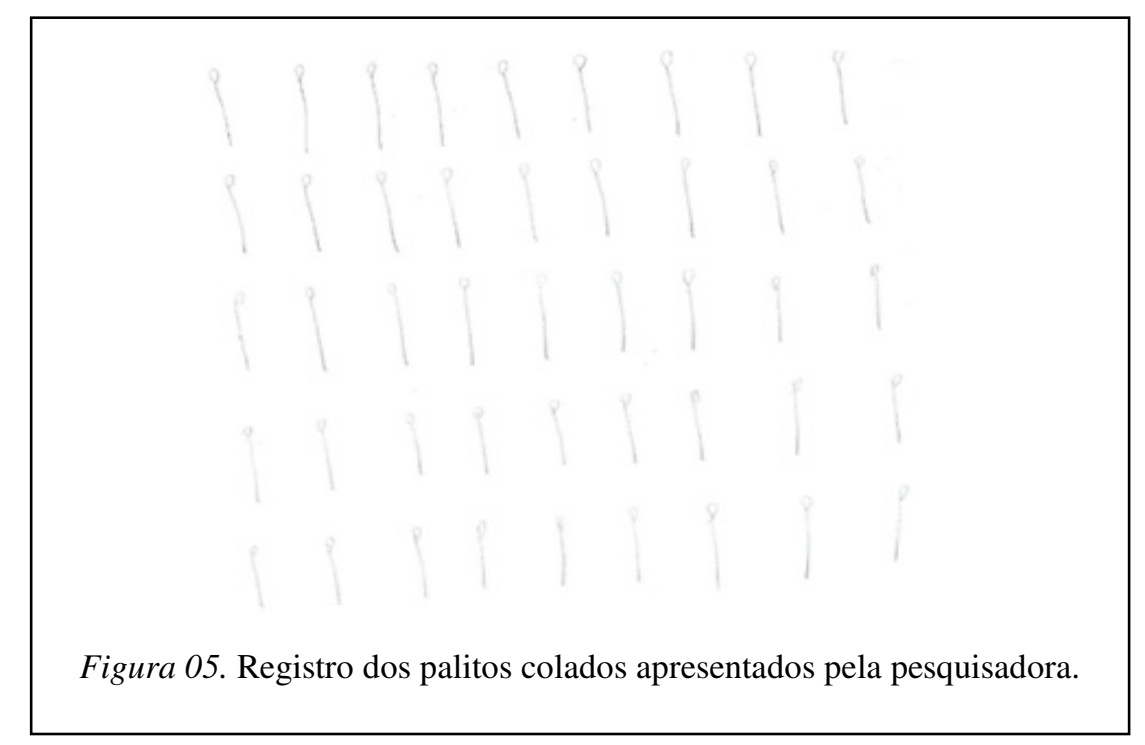

Todavia, G. não estabeleceu a relação biunívoca para todas as unidades corretamente, provavelmente em função da hipótese de dificuldade de percepção espacial. A esse respeito, a pesquisadora procurou engajar G. numa estimativa cognitiva de quantidades, para auxiliar na percepção dos equívocos da contagem, mas tal proposta não foi efetiva. A pesquisadora, então, revelou a quantidade de palitos que havia sido desenhada em sua produção e propôs uma soma à quantidade de palitos colados por G., 
que optou pela resolução de tal situação a partir da operação convencional de adição (Figura 6).

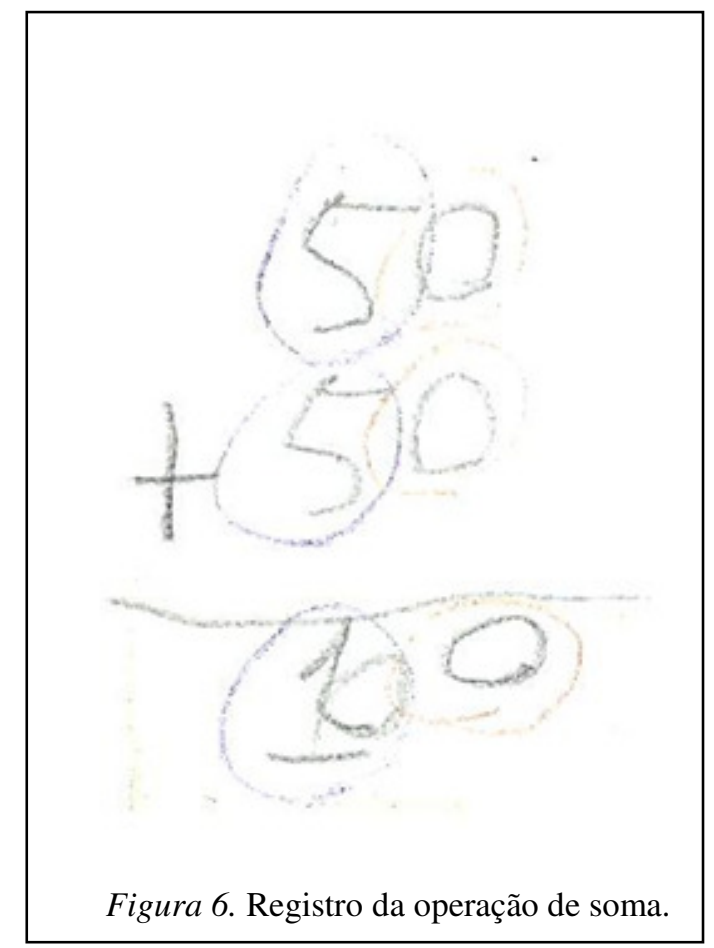

A realização da operação revelou que G. já teve experiências com a resolução desse tipo de operação, mas ele não se engajou na avaliação da razoabilidade do resultado, pois aceitou o resultado de sua operação, admitindo que o resultado de $50+50$ seja 10 . O que aconteceu foi que G., ao somar os algarismos cinco, relativos à segunda ordem de grandeza - dezena - não registrou o resultado 10 , pois já havia um 0 posicionado na casa das unidades, referente à soma das unidades.

O julgamento da razoabilidade do resultado é um dos aspectos do senso numérico e a ausência desse julgamento, nesse caso, impediu a autocorreção da resolução da operação por parte G. Além disso, tal característica também pode atrapalhar a compreensão da convenção da resolução da operação em relação à questão do valor posicional do número. 
Em virtude disso, a pesquisadora optou por solicitar que G. destacasse, por meio de cores diferentes, as colunas que representam o valor posicional de cada algarismo e o resultado de sua soma com o algarismo posicionado imediatamente abaixo, buscando utilizar o conhecimento sobre fatos numéricos que G. demonstrou para que ele percebesse a não razoabilidade do resultado que ele obteve.

Apesar disso, inicialmente tal tomada de consciência não aconteceu. A pesquisadora propôs a situação de utilização de uma escala numérica - aproximação de números - para auxiliar na compreensão, o que não alcançou o resultado desejado. A pesquisadora ficou preocupada com o fato de que avançar em situações de mediação que não levassem à compreensão da questão poderiam causar confusão a G., como ele próprio verbalizara. Ela, então, optou por explicitamente corrigir a operação realizada e depois relacionar o resultado obtido com a situação da escala numérica. A inclusão do zero na coluna das dezenas foi realizada, portanto, a partir da interação com a pesquisadora, como pode ser observado no trecho transcrito a seguir:

"P: Olha, eu vou cobrir essa parte do zero. Aí, cinco mais cinco é dez, está certo, mas olha o resultado aqui.

G: Um.

P: O que está de esquisito aí?

G: O que está de esquisito aí?

P: É, você disse que cinco mais cinco é dez, mas só está aparecendo o um.

G: O que tem de esquisito aí?

P: Cinco mais cinco não é dez?

G: É.

P: Então o resultado aqui não tinha que ser dez?

G: Sim.

P: Mas tem o resultado escrito aqui?

G: Não. Só tem um.

P: Então o que tem que fazer para arrumar?

G: O que tem que fazer para arrumar? Colocar o zero perto do um.

P: Então faz aí, mas tem que ser dentro da bolinha azul por que faz parte do resultado dessa conta. Vamos ver qual o resultado deu agora? Mas tudo junto, vou pegar outra cor de lápis. O resultado da conta então é tudo isso aqui.

G: Cem." 
G. propôs a realização de uma contagem para a conferência do resultado, e foi necessária a sinalização de que G. não estava estabelecendo relação um a um de forma consistente. Quando questionado do motivo pelo qual a primeira contagem não havia chegado à quantidade correta, a hipótese levantada por G. é de que ele pulou uma fileira. Tal resposta denota desarticulação com o conhecimento anterior sobre a formação de fileiras com base dez e explicita a necessidade de reforço constante de tal aspecto. Outra desarticulação nesse sentido, que também demonstrada, é que G. tinha o conhecimento de fatos numéricos sobre as somas sucessivas em base dez, o utilizava de forma intuitiva quanto realizava contagens de fileiras, mas não explicitou tal conhecimento verbalmente ou por meio de operações matemáticas.

A representação da relação dos palitos colados com as operações de multiplicação foi retomada, com a pesquisadora atuando de forma a tornar explícito tal conhecimento a cada registro de operação. G. registrou ao lado de cada fileira a quantidade, o resultado das somas sucessivas e as operações de multiplicação, como demonstrado nas Figuras 7 e 8.

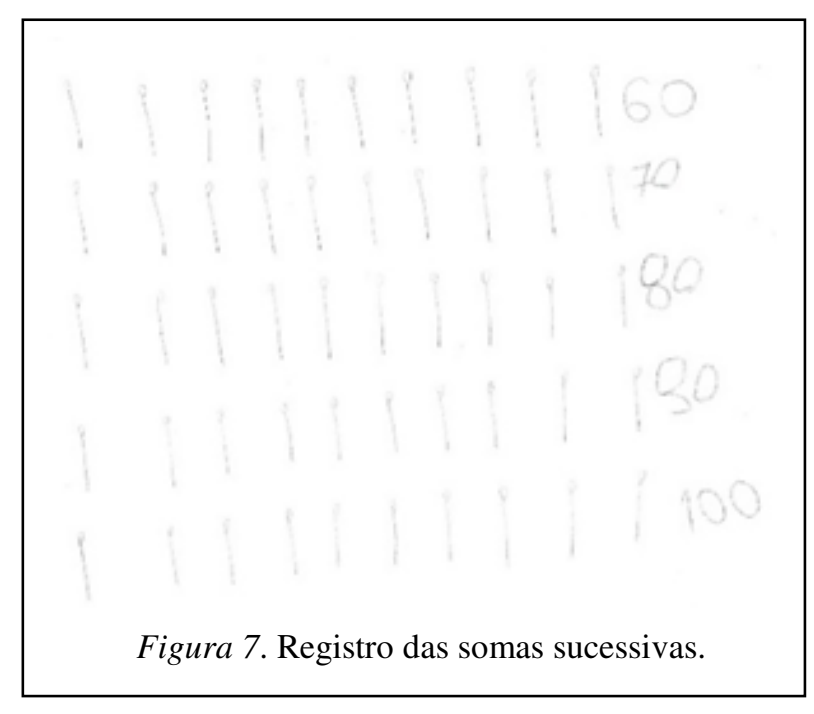




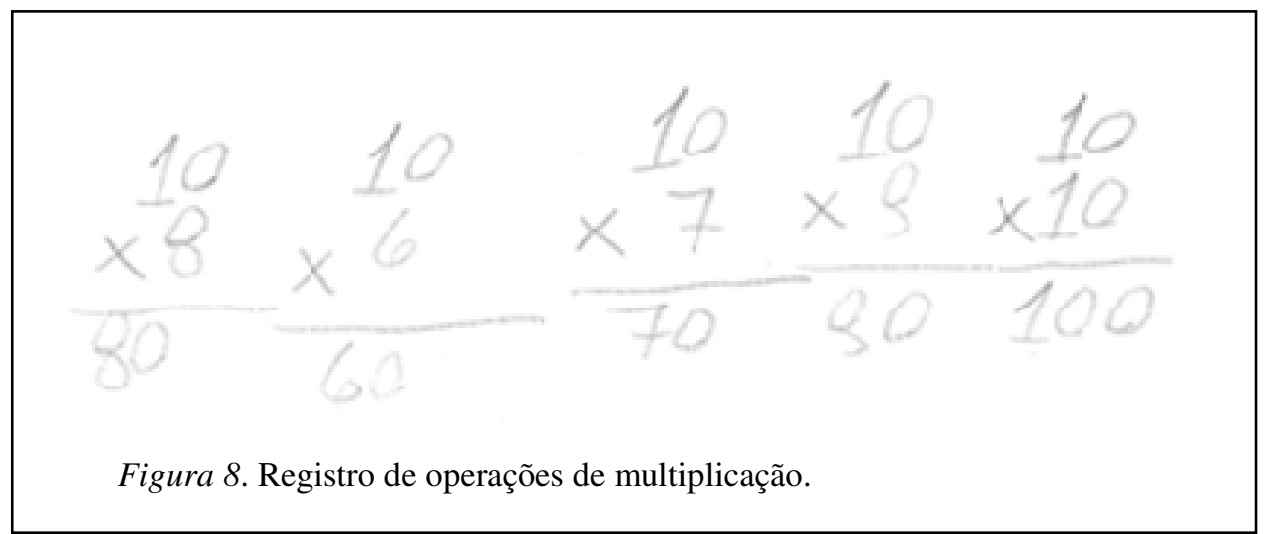

\subsubsection{Sexta sessão de intervenção psicopedagógica.}

\section{Data: 16/03/2015 Duração: 52 minutos}

Objetivos da sessão: Propor situações envolvendo noções referentes a conceitos temporais e sua representação no calendário; propor situações-problemas relacionadas ao campo conceitual das estruturas aditivas e multiplicativas; propor situações de agrupamentos de quantidades discretas em diferentes bases.

2.4.3.6.1 Desenvolvimento, resultados e discussão da sexta sessão de intervenção psicopedagógica.

$\mathrm{Na}$ primeira parte desta sessão de intervenção, foi proposto um conjunto de atividades referentes ao campo conceitual das noções temporais, especificamente relacionado ao uso convencional do calendário, à organização das informações no instrumento e ao conceito da formação das semanas a partir dos dias. Na segunda parte da sessão, foram propostas atividades referentes ao campo conceitual das estruturas aditivas e multiplicativas, especificamente em relação a situações de aumento e combinação e de razão, respectivamente. A terceira parte dessa sessão foi referente à proposta de realização de agrupamentos com diferentes bases. Para a realização das atividades, foram utilizados: um calendário de mesa, as representações da colagem de palitos produzidas nas sessões 
anteriores, folhas de papel sulfite e lápis grafite.

A primeira situação proposta foi a da localização da data corrente no calendário. G. equivocou-se em um dia no reconhecimento da data. A pesquisadora buscou associar o reconhecimento do número do dia ao dia da semana, visto que, em outras situações, já havia sido discutido entre pesquisadora e participante acerca do dia da semana em que as sessões ocorrem (segundas-feiras). Para tanto, a pesquisadora sinalizou com um gesto sobre o calendário mostrando que o dia 16 não estava posicionado em linha reta em relação à segunda-feira. Diante de tal mediação, G. modificou sua resposta.

Durante a interação com a pesquisadora, G. revelou a origem de seu equívoco. Ele estava portando um relógio digital com a data atrasada em um dia. Portanto, sua primeira resposta foi baseada nesse instrumento. Vale ressaltar, entretanto, que G. não se remeteu à lógica convencional do calendário para verificar a data do dia corrente, o que pode significar que, apesar de conhecer alguns aspectos de seu funcionamento, como a sequência dos dias da semana e dos meses, por exemplo, G. ainda não dispõe de todas as competências para o uso autônomo desse instrumento.

Por outro lado, no momento em que a pesquisadora realizou o gesto demonstrando o posicionamento do numeral identificador do dia fora da coluna no nome do dia, G., ao rejeitar essa forma de expressar a organização das informações no calendário, demonstrou conhecer, mesmo que intuitivamente, a regra de posicionamento entre o nome e os números dos dias. Em virtude desses dados, pode-se dizer que G., no momento, apresentava a fragmentação no conceito de registro de tempo nas suas representações entre o relógio e o calendário.

Após a situação de encontrar a data corrente, a pesquisadora instigou G. acerca do significado das linhas em que os dias dos meses são organizados, ou seja, as semanas. A 
pesquisadora ofereceu uma mediação expositiva sobre a referida organização, o que não foi efetivo em termos de mobilização conceitual por parte de G., visto que, quando solicitado a localizar quantas semanas formavam o mês em questão, por exemplo, ele engajou-se numa contagem de todos os dias do mês, ou seja, utilizou um esquema prévio de contagem, numa situação em que era necessário outro tipo de esquema de ação, como pode ser observado no trecho a seguir:

"P: Então, aqui a gente tem uma semana.

G: Outra semana.

P: O mês de março tem quantas semanas então?

G: 31 .

P: 31 semanas?

G: É.

P: As semanas são as linhas, essas aqui. Tem 31 linhas aqui?

G: Não.

P: Quantas linhas tem?

G: $1,2,3,4$."

Seguiu-se, então, uma série de novas tentativas por parte da pesquisadora para proporcionar a compreensão do conceito de semana, como circular um conjunto de dias formando uma semana, determinar a próxima semana que seria iniciada, repetição da associação entre semana e uma linha no calendário e explicitação dos meses divididos em semana. As respostas elaboradas por G. constituíram-se em repetição da orientação dada pela pesquisadora, como já observado em situações anteriores, confirmações de entendimento e respostas contextualizadas à situação, mas não adequadas às solicitações feitas. Tais respostas sugerem a persistência um conhecimento desorganizado e incompleto a respeito da representação temporal em uso de calendário, o que impedia sua atuação operatória, ou seja, G. não conseguiu tratar a situação devido aos esquemas utilizados serem desorganizados, incompletos ou ineficientes ao contexto em questão. As mediações, por parte da pesquisadora, e as inconsistências conceituais nas respostas de G., em operar 
com o conceito de semana, podem ser observadas no extrato transcrito a seguir:

"P: Quantos dias como esse a gente precisa para formar uma semana?

G: Uma semana.

P: Isso, quantos dias tem dentro de uma semana? Dessa linha toda que eu contornei? Quantos dias tem dentro desse grupo?

G: Conta do 16 ou do 15? Do 15.

P: Do 15, ele está dentro do grupo.

G: Ah, tá. 15, 16, 17, 18, 19. Ah tá. 1,2,3,4,5,6,7.

P: Então, para formar uma semana a gente precisa de quantos dias?

G: 7.

P: 7. Então aqui tem 7 dias, aqui tem 7 dias e aqui tem 7 dias. Então, tem o mês com todos esses dias aqui. Quando a gente faz grupinhos com sete dias do mês, a gente acha as semanas.

G: Ah tá, entendi.

P: Todos esses dias são os dias do mês. Daí a gente arruma sete, uma semana, mais sete, outra semana.

G: Ah, tá.

P: Quantas semanas deu para organizar em março, conta aí.

G: Quantas semanas deu para organizar em março?

P: É, conta aí. Quantos grupinhos de 7 fizeram aí?

G: 1,2,3,4,5,6,7,8,9,10,11,12,13,14,15,16,17,18,19,20,21,22,23,24,25,26.

P: Uhum. A gente conseguiu organizar então 26 semanas?

G: Acho que não.

P: Qual o problema?

G: Que até o dia 31.

P: O que são as semanas mesmo?

G: A semana? Segunda, terça, quarta, quinta, sexta e sábado.

P: Isso. É uma linha dessa daqui. E aqui forma uma semana, outra semana, outra semana, outra semana. Quanta vezes então formaram semanas aqui?

G: $1,2,3,4$.

P: Isso. 4 semanas. Porque semanas são grupinhos. Tem que pegar os dias e formar grupinhos. Grupinhos de 7 dias.

G: Ah tá, entendi. Agora eu entendi."

No primeiro procedimento de contagem realizado por G., pode-se observar que sua primeira resposta foi a de recitar a sequência numérica, conforme presentado no calendário para, em seguida, corrigir-se, considerando cada dia como uma unidade discreta do subconjunto semana, não importando sua sequência no conjunto maior, mês, ou seja, 
prevaleceu o princípio de irrelevância da ordem. Tal correção demonstra que G. percebeu que seu esquema de contagem inicial não estava adequado para a natureza da situação proposta, o que mostra ganhos nesse sentido, já que, esse era um aspecto que chamava a atenção em seu desempenho durante algumas sessões de intervenção. Considerando o entendimento advindo da teoria dos campos conceituais, em que a formação de um conceito depende de um conjunto de situações que lhe dê significado, pode-se afirmar que tal dado seja uma evidência de desenvolvimento conceitual do sujeito, que foi produzido ao longo das sessões de intervenção. A pesquisadora optou por utilizar mais uma estratégia de mediação ao solicitar que G. registrasse, de forma discursiva, o conhecimento produzido sobre o conceito de semana. Isso porque, ao longo das sessões de intervenção, ele tinha mostrado boa capacidade de memória declarativa, além de que essa produção poderia constituir um registro que a ser retomado posteriormente.

O segundo conjunto de situações desenvolvidas, naquela sessão de intervenção, dizia respeito ao campo conceitual das estruturas aditivas e multiplicativas, especificamente em relação a situações de aumento e combinação e de razão, respectivamente. G. espontaneamente demonstrou ter compreendido, pelo menos para a situação em questão, a relação existente entre a representação de operações usando material concreto e a representação através de operações convencionais, quando retomou as atividades realizadas na sessão anterior:

"P: Olha só, a gente também viu que a gente consegue representar o que a gente fez com os palitos usando números.

G: Ah, é, acho que eu sei qual é.

$\mathrm{P}: \mathrm{O}$ que?

G: Os números? Esse aí, olha.

P: É. Vamos tentar lembrar o que a gente fez?

G: 10 vezes 3,30 .

P: Isso é com os números. E se eu quiser fazer com os palitos, o que significa 10 vezes 3 ? 
G: Porque esse aqui... O que significa 10 vezes 3 ?

P: É, se eu for olhar nos palitos, o que significa esse 10 vezes 3 ? Como é que a gente mostra nos palitos, a mesma coisa que a gente está mostrando com os números?

G: Porque 10, 3 vezes, é igual a 30."

Em face de termos à disposição 100 palitos desenhados, produtos das mediações realizadas nas situações de intervenção anteriores, a situação colocada para G. foi a de encontrar formas de alcançar a quantidade de 100 unidades. Para resolver tal situação, G. criou uma hipótese compatível com o campo conceitual das estruturas aditivas, através de em esquema de adição que já dominava, recitando um fato numérico. Em seguida, ele rejeitou essa hipótese, justificando sua rejeição pelo resultado obtido:

"P: Isso, outro jeito de juntar grupinhos de 10 palitos e chegar no 100.

G: Ah, isso aí, vou ter que pensar.

P: Vamos pensar então.

G: 100 mais 100 não vai chegar no 100 porque é 200.”

Nesse trecho, pode-se observar uma competência relacionada ao conceito de número, tratando-se da compreensão da operação que permite resolver uma determinada situação proposta. G. propôs, então, outra resposta, utilizando o campo conceitual das estruturas multiplicativas: “G: Ah, pensei. 100 vezes 1 é igual a 100”. Tal estratégia, porém, denota menor reconhecimento do efeito relativo das operações nos números, ou seja, reconhecer como as quatro operações básicas afetam o resultado, já que o engajamento numa multiplicação de 100 por 1 não mobilizou os agrupamentos sucessivos em base 10, conforme solicitava a situação. Esse desempenho também pode ser interpretado como uma não efetividade das sessões de intervenção anteriores, em que situações dessa natureza foram vivenciadas.

Diante dessa consideração, a pesquisadora optou por recortar grupos de dez unidades para disponibilizar para que G. pudesse manipular, visando oferecer um apoio 
para a resolução das situações de sucessivos agrupamentos. Ao ter todos os dez grupos de dez unidades recortados, a pesquisadora questionou à $G$. qual o total de unidades disponíveis e, novamente, observou-se uma fragmentação conceitual, como pode ser observado no trecho transcrito a seguir:

"P: Muito bem 10 grupinhos, iguais aos que a gente tinha aqui. 1,2,3,4,5,6,7,8,9,10. Só que esses aqui estão juntos e esses estão recortados. Quantas unidades eu desenhei em cada grupinho?

G: 10 .

P: Então aqui tem 10 desenhado...

G: 10, 10, 10, 10 .

P: Tudo 10. Quantas vezes eu desenhei o 10, então?

G: O 10? 1,2,3,4,5,6,7,8,9,10.

P: Então se eu desenhei o 10, 10 vezes, juntando tudo dá quanto?

G: Dá quanto?

P: Isso, se quiser fazer aqui com números. Eu desenhei o 10, 10 vezes.

G: 10 vezes 10 dá 20 . Não sei. É 20."

A pesquisadora optou por sugerir a realização de uma operação convencional para descobrir o total de unidades disponíveis na situação. A seguir, apresenta-se a transcrição das interlocuções referentes à resolução dessa operação:

"P: Quer tentar fazer aí para a gente conferir?

G: Pode ser. Ih, sei não. Não sei se é 20, não. Melhor fazer.

P: Então faz para a gente conferir.

G: É. 0 vezes 0 é 0.1 vezes um 1 é 1 . Eita.

P: Que foi, qual problema.

G: Acho que não sei não, acho que está errado.

P: Porque você acha?

G: 1 vezes 1.0 vezes 0 é 0.1 vezes 1 é 1 .

P: E qual o problema?

G: 10 vezes 10 é 10 .

P: E pode, 10 vezes 10 dá 10 ?

G: Não.

P: Porque não?

G: Porque sim, porque 10 vezes 10 . Porque é a conta. 10 vezes 10 não dá 10.” 
Na resolução dessa operação, pode-se perceber que são expressos dois conflitos, um caraterizado pela dificuldade em proceder à operação convencional, por falta de domínio das regras de resolução, que pode ter origem tanto conceitual, quanto procedimental, e outro referente à percepção da inadequação do resultado obtido. Anteriormente G. havia verbalizado que 100 vezes 1 seria 100 e, durante a resolução da operação, obteve um resultado incompatível com seu conhecimento anterior.

Pode-se observar também um entendimento da realização das operações matemáticas como algo inflexível, através da assertiva "É a conta". Tal dado pode significar que, apesar de verbalizar o reconhecimento de que existe uma relação entre as representações de operações matemáticas com material concreto e através das operações convencionais, G. não compreendeu a natureza dessa relação.

A pesquisadora ofereceu suporte nos agrupamentos de dez unidades recortadas e forneceu também apoio verbal. Desse modo, G. foi auxiliado na obtenção do resultado desejado, o que permitiu a tomada consciência de seu próprio desempenho, a autocorreção e auxiliou na compreensão da relação entre representação concreta e representação algorítmica, como se pode observar no trecho a seguir. Esse dado pode significar que a continuidade de vivências de situações semelhantes a essa pode auxiliar G. a progredir em sua compreensão a respeito dos campos conceituais das estruturas aditivas e multiplicativas.

"P: Ah, entendi. Olha, vamos ver se esse aqui ajuda a gente. Aqui, esses recortados aqui, não são iguais a esses aqui?

G: São.

P: Aqui a gente não desenhou 10 palitos 10 vezes também?

G: Sim.

P: 1 vez 10 palitos, 2 vezes 10 palitos, 3 vezes 10 palitos, 4 vezes 10 palitos, 5 vezes 10 palitos, 6 vezes 10 palitos, 7 vezes 10 palitos, 8 vezes 10 palitos, 9 vezes 10 palitos, 10 vezes 10 palitos. A gente fez a mesma coisa, só que aqui está desenhado e ali está recortado. 
G: 10 vezes 10 dá 100 .

P: Isso. 10 vezes 10 dá 100 .

G: Oh, my Gosh.

P: Que anotar aqui?

G: Pode. Err, e eu falando que é 10. Ah, tá, 10 vezes dá 100. Está certo.”

A próxima atividade mediada foi a da formação de agrupamentos com base 20 . A pesquisadora iniciou a atividade e G. deu continuidade, demonstrando compreender a proposta do agrupamento. Porém, ele ainda demonstrou fragmentação no esquema de agrupamento, conforme se pode observar pela fala expressa na interação transcrita a seguir:

"P: Então se a gente juntar todos esses nossos 10 aqui e a gente contar a gente vai chegar no 100. Aqui, a gente juntou todos, mas, vamos tentar fazer de outro jeito? O que acontece, por exemplo, se eu ficar juntando de dois em dois grupinhos, olha. Dois grupos desses...

G: Aí dois desses, dois desses, dois desses e dois desses.

$\mathrm{P}: \mathrm{O}$ que aconteceu aqui?

G: O que aconteceu? Formou dois grupos.

P: Dois grupos? Me mostra onde que é um grupo.

G: Aqui.

P: Um grupo agora eu juntei esses dois, olha, esse aqui é um grupo, esse aqui agora é outro grupo.

G: Esse aqui é outro.

P: Esse aqui é outro grupo e esse é outro. Então quantos grupos a gente montou? G: $1,2,3,4,5,6,7,8,9,10.10$.

P: É, só que 10 é juntando todos. Só que agora esse aqui virou um grupinho, vou juntá-los com fita. Esse aqui virou um só agora, juntei eles. Esse aqui virou um só. Esse aqui virou um só. É só um. Esse aqui virou um só. Quantos grupos a gente tem agora? O grupo é esse aqui, olha, que é feito de dois. Aqui tem um grupo. Um.

G: Dois, três, quatro, cinco.

P: Quantos grupos a gente fez então?

G: 5."

Tal fragmentação também pode ser observada quando a pesquisadora modificou o questionamento da quantidade e grupos formados, para quantas unidades estavam contidas em cada grupo:

"P: Em cada grupo, ficaram quantas unidades?

G: 10. Quantas?

P: É, veja aí, quantas unidades tem em cada grupo. 
G: 1,2,3,4,5,6. Ah, peraí. 1 unidade, 2 unidades, 3 unidades, 4 unidades, 5 unidades, 6 unidades, 7 unidades, 8 unidades, 9 unidades. Contar até aqui, não é?

P: É, todos esses que são do grupinho.

G: 10 unidades, 11 unidades, 13 unidades, 14 unidades. Ih, esqueci.

$\mathrm{P}: \mathrm{O}$ que aconteceu?

G: Fiquei confuso.

P: É? Então começa de novo para a gente corrigir.

G: 1 unidade, 2 unidades, 3 unidades, 4 unidades, 5 unidades, 6 unidades, 7 unidades, 8 unidades, 9 unidades, 10 unidades, 11 unidades, 12 unidades, 13 unidades, 14 unidades, 15 unidades, 16 unidades, 17, 18, 19, 20.

P: Ah, então em um grupinho tem 20 unidades."

Pode-se observar também que há necessidade de estabelecer, de forma mais clara, essa alternância entre os tipos de situações. Isso porque, como pode ser observado no trecho transcrito a seguir, quando a pesquisadora propõe essas alternâncias de situação problema de forma súbita, G. parece ter maior dificuldade em operar com as informações que já possui:

"P: Aqui tem 20, aqui tem 20 unidades, aqui tem 20 unidade, aqui tem 20 unidades e aqui tem 20 unidades.

G: É.

P: Então, quantos grupinhos de 20 unidades a gente tem?

G: 5 .

P: 5 grupinhos de 20 unidades. Se eu juntar todos esses 5 grupinhos de 20 unidades, colocar 20 unidades 5 vezes, quanto é que vai dar tudo junto?

G: $1,2,3,4,5,6,7,8,9,10$.

P: Isso, isso são os grupinhos de 10. Mas agora eles não são mais grupinhos de 10 , eles são grupinhos de?

G: 5 .

P: 5 ? Tem 5 unidades aqui?

G: 20. Err."

A próxima situação proposta constituiu-se de sucessivas somas de 20 unidades, referentes a cada um dos cinco grupos. Para tanto, G. optou por realizar registros aritméticos convencionais da adição no papel e buscou resolvê-los sem apoio em quantidades discretas, com auxílio da pesquisadora, para considerar todas as parcelas da soma:

G: 20 mais 20 acho que dá 40.0 mais $0,0.2$ mais $2,4.40$. 
P: Então esses 20 desse grupinho aqui, mais esses 20 desse grupinho aqui deu 40 ?

E se eu colocar mais 20 ?

G: 20 mais 20 ?

P: Olha, 20 mais 20 deu 40, certo?

G: Certo.

P: E se eu colocar mais 20?

G: 50. Ah, 20 mais 20 ? 20 mais 20 deu 40.

P: Isso, até aqui deu 40. Coloquei mais 20 agora.

G: Dá... 20 mais 20 mais 20.

P: Isso, exatamente. Isso mesmo.

G: Vou fazer aqui que é melhor. 0 mais 0 mais $0,0.2$ mais 2, 4, com mais 2, 5,6. 60. Oh, my Gosh.

P: Então a gente já colocou, 20 mais 20 mais 20. E se eu colocar mais um, olha.

$\mathrm{G}$ : Se colocar mais um?

P: Isso.

G: 20 mais 20 mais 20 mais 20 .

$\mathrm{P}$ : Isso, isso mesmo.

Quando cometeu um equívoco, G. foi encorajado a recomeçar seu registro e a mediação da pesquisadora permaneceu da mesma natureza, ou seja, auxiliar a consideração de todas as parcelas a serem somadas. O registro da operação está disponível na Figura 09:

"G: Eita poxa! 20 mais 20. O que é isso? Quase que eu coloquei o 4 aqui.

P: É? Você quer fazer de novo do lado?

G: É apagar aqui.

P: Não precisa apagar não, faz de novo aqui do lado.

G: Aqui do lado?

P: A gente começa de novo, não tem problema.

G: 0 com 0, 0, mais 0, 0, mais 0, 0. Acho que dá. Agora ficou confuso.

P: Então vamos fazer de novo. Olha, 20 mais $20 \ldots$

G: 20 mais 20 mais 20 mais 20.

P: Isso, 20 mais 20, mais 20, mais 20. Isso.

G: 0 com 0,0 , mais 0 , 0 , mais $0,0.2$ mais 2, 4, com mais 2, 5,6. 2 mais 2, 4, com mais $2,5,6$, com mais $2,7,8$.

P: Isso.

G: Dá 80.

P: Isso, então a gente juntando esses daqui, olha, 20 mais 20, mais 20, mais 20 , deu 80." 


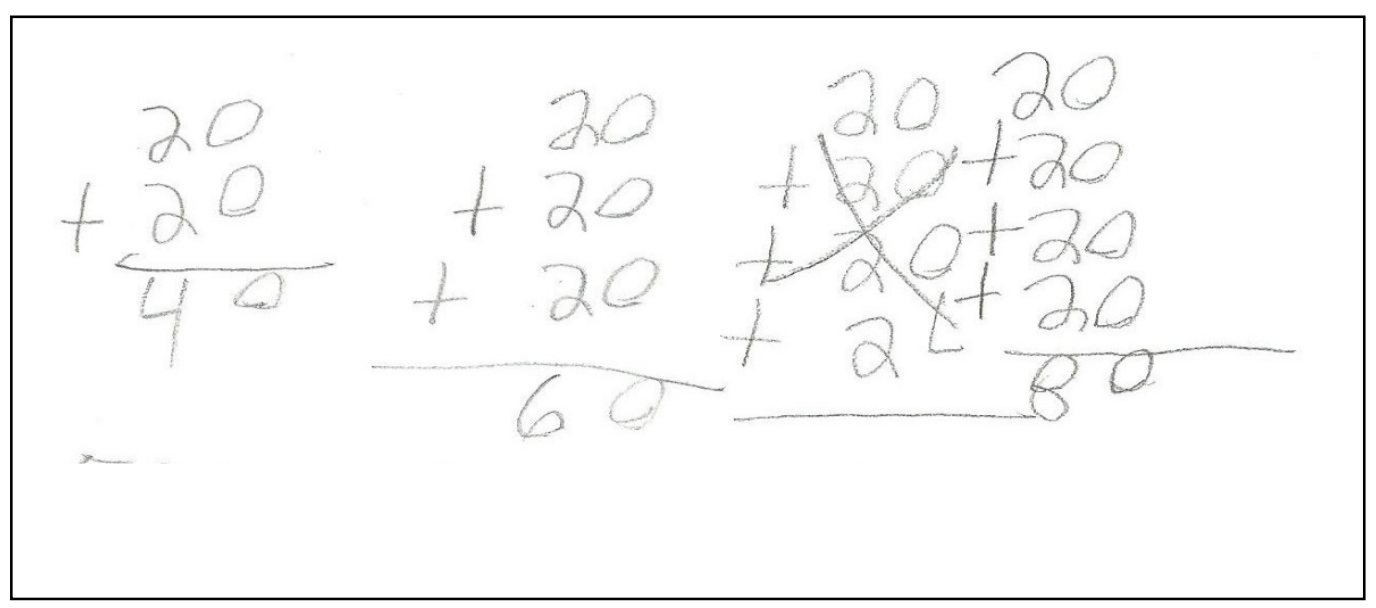

Figura 9. Registro das operações de adição.

No momento em que todas as parcelas já estavam registradas e G. já havia realizado o registro da soma das unidades e ia proceder ao registro da soma das dezenas, foi necessária a intervenção da pesquisadora para demonstrar para G. que era necessário o registro de dois algarismos ( 1 e 0 ), apesar de já haver um 0 registrado no total, como pode ser observado na Figura 10. Tal característica, apresentada por G., denota compreensão insuficiente da noção de valor de lugar.

"P: Olha. Vamos lá juntos. 2 mais 2, 4.

G: 2 mais 2, 4, com mais 2, 5,6, com mais 2, 7,8, com mais 2, 9, 10. Eita.

P: Esse 0 aqui é dessa soma aqui, certo?

G: Certo.

P: Então esse aqui é dessa soma aqui. E todos esses dois que você somou deu?

G: 10 .

P: Cadê o 10? Só tem o 1 aí.

G: Ah é.

P: Então bota o 0 aí. Você disse que todos esses juntos davam 10. Hum, agora formou 100, olha.

G: Ah.

P: É porque esse 0 aqui é daqui e esse 0 aqui é do 10 , da soma de todos os 2.

G: Ah tá, dá 100.” 


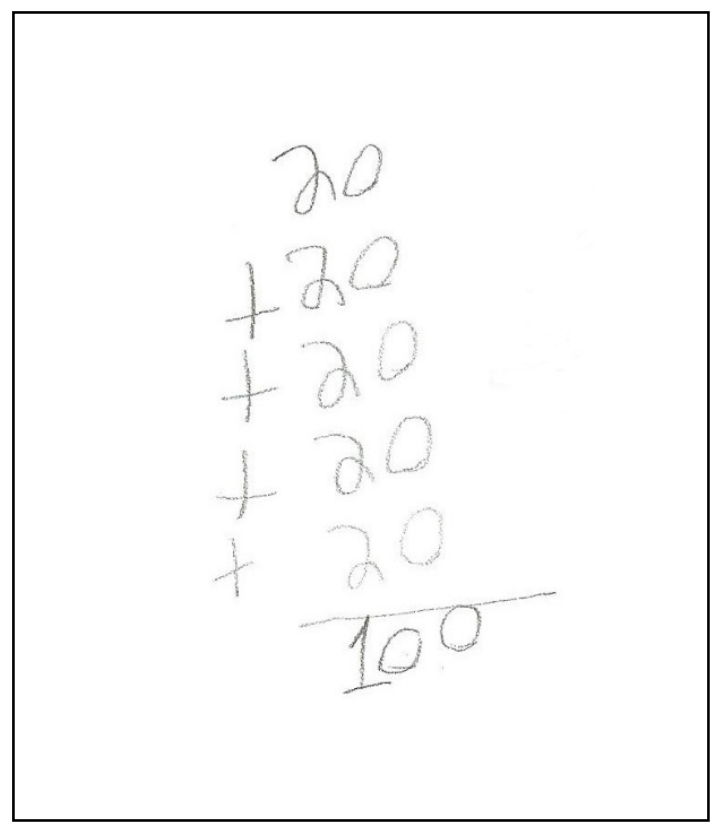

Figura 10. Registro de operação de adição.

Os dados dessa sessão de intervenção, apresentados e discutidos, foram considerados para o planejamento das próximas sessões de intervenção.

\subsubsection{Sétima sessão de intervenção psicopedagógica.}

Data: 23/03/2015 Duração: 49 minutos

Objetivos da sessão: Incentivar a compreensão dos sucessivos agrupamentos de unidades de medida de tempo; incentivar a compreensão das possibilidades de agrupamentos em diversas bases, atingindo a mesma quantidade; incentivar a compreensão da relação entre as operações de adição e multiplicação.

2.4.3.7.1 Desenvolvimento, resultados e discussão da sétima sessão de intervenção psicopedagógica.

Nessa sessão, foram desenvolvidas atividades pertinentes a noções temporais utilizando o relógio e o calendário, atividades de agrupamento em base 5, situações de resolução de operações de adição e multiplicação em contextos de situações-problemas. Os 
materiais utilizados foram: o calendário de mesa atual, com um mês representado em cada página, o relógio analógico, numerado de 1 a 12 e com marcações referentes aos segundos, folhas de papel e lápis grafite.

Na identificação do horário de início da sessão, G. informou corretamente as horas, baseado em seu relógio digital. $\mathrm{O}$ não reconhecimento da igualdade das horas representados no relógio digital e no relógio analógico denota o não conhecimento do funcionamento do relógio em base 60 e seus sucessivos agrupamentos.

G. virou as páginas do calendário para encontrar a página referente ao mês corrente, o que pode ter relação com as intervenções, realizadas anteriormente, em que tal conhecimento foi promovido. Por outro lado, G. manteve a dificuldade no estabelecimento do ponto inicial e final em situação de contagem usando o calendário, quando o início da contagem não coincide com o começo do mês.

Nesse encontro, pôde-se constatar um avanço no sentido de mobilização de agrupamentos dos dias em semanas, de semanas em meses e de meses em anos. G. demonstrou conviver com esse tipo de informação, mas não demonstrou conhecer a lógica subjacente a esses tipos de agrupamentos.

No momento do reagrupamento dos grupos de dez palitos desenhados, G. pareceu estar em processo de tomada de consciência sobre a possibilidade de obtenção de um mesmo resultado, a partir de diversas operações, tanto referentes ao campo conceitual das estruturas aditivas quanto das estruturas multiplicativas. Isso foi observado quando ele engajou-se a retomar verbalmente todas as operações já registradas nas sessões anteriores (Figura 8). A pesquisadora buscou auxiliar na sistematização desse fato, explicitando-o verbalmente e solicitando que G. relacionasse os 10 grupos de 10 palitos desenhados a uma das operações registradas. 
A pesquisadora propôs a realização do reagrupamento dos grupos de 10 palitos em base cinco e incentivou G. a descobrir a quantidade total de palitos sem utilizar a contagem. G. engajou-se em uma operação de multiplicação que foi elaborada a partir do algoritmo convencional. Ao dobrar a quantidade de agrupamento de 10 palitos, a pesquisadora buscou incentivá-lo a descobrir a quantidade total de palitos a partir da equiparação dos dois grupos. Inicialmente, G. não conseguiu compreender tal atividade e a mediação estabelecida teve o objetivo de retomar os conhecimentos já mobilizados anteriormente.

G. realizou uma operação de soma de cinquenta mais cinquenta para o cálculo do total de palitos desenhados nos dois grupos que estavam sendo manipulados. Para o registro do resultado da soma das dezenas, ele registrou apenas 1 , visto que já havia um 0 registrado, referente à soma das unidades. Tal ação sugere que G. não compreende o valor posicional dos números e sua relação com a resolução das operações aritméticas convencionais, do mesmo modo como já foi observado em outras sessões de intervenção.

Por outro lado, em várias situações durante a intervenção, G. produziu respostas às situações de interação que, ou se remetiam a uma situação imediatamente anterior, ou as outras situações de interação com a pesquisadora, sem relação contextual. Essa característica é relevante para o planejamento e reflexão da pesquisadora acerca da interação com G., assim como a impressão registrada na sessão de intervenção anterior, a respeito da sobreposição de interações como possível causadora de dificuldades para G.

Para as próximas sessões, planejou-se continuar a abordagem de agrupamentos e seus usos convencionais presentes na lógica do relógio e do calendário, utilizando o contexto da organização de uma festa de aniversário, além da resolução de situações problemas, envolvendo os algoritmos convencionais das operações matemáticas básicas. 


\subsubsection{Oitava sessão de intervenção psicopedagógica.}

Data: 06/04/2015 Duração: 61 minutos

Objetivos da sessão: Propor situações-problemas de contagem e mediar suas soluções com o uso de calendário e de relógio analógico e digital; propor o planejamento de uma festa de aniversário e a resolução de situações-problemas referentes ao campo conceitual das estruturas aditivas e multiplicativas.

\subsection{Desenvolvimento, resultados e discussão da oitava sessão de intervenção} psicopedagógica.

Nessa sessão, os materiais utilizados foram: um calendário de mesa, umrelógio analógico, um relógio digital de pulso pertencente a G., lápis grafite e papel A4. A primeira etapa, dessa sessão de intervenção, se iniciou com G. localizando a data corrente no calendário, antecipando a rotina já estabelecida. G. antecipou e fez referência ao que tinha sido conversado em sessões anteriores sobre a representação de domingos e feriados.

Foram propostas comparações entre a marcação das horas nos relógios analógico e digital e G. demonstrou conhecer que a formação da marcação do tempo envolve horas e minutos, apesar de não dominar a lógica da relação entre esses dois conjuntos. Em sessões de intervenção futuras, a composição das horas a partir de agrupamentos de minutos poderá ser explorada por meio da manipulação do relógio analógico.

Foi apresentada novamente uma situação de contagem de dias vivenciada na sessão de intervenção anterior, que dizia respeito ao cálculo da quantidade de dias faltantes para a chegada do aniversário de G., que utilizou o registro do algoritmo de soma, disponibilizado pela pesquisadora sobre a mesa, evidenciando a retomada da resolução de uma situação 
anterior para a situação atual.

Na situação em que deveria descobrir quantos dias se passariam desde o início do mês de julho até chegar sua data de aniversário, G. utilizou esquema de contagem de forma adequada à situação proposta. Várias situações de contagem foram sugeridas pela pesquisadora sempre com o ponto de referência final na data de aniversário de G. (26 de julho). Todas as vezes que a contagem se referia a uma sequência de dias contínua, na mesma página do calendário, G. evidenciou competência para contagem. Nas situações em que o intervalo de tempo a ser contado era um subconjunto do conjunto de dias do mês, $\mathrm{G}$. evidenciou dificuldade. A proposta visava vivenciar outras situações de natureza semelhante para verificar a origem de tal dificuldade.

A pesquisadora iniciou a terceira etapa, dessa sessão de intervenção, com o planejamento da festa de aniversário. Inicialmente G. referiu que não tinha interesse na realização de uma festa de aniversário, sendo que isso não era mais necessário em sua idade, sinalizando sua posição dentro da adolescência. Após a explicação da pesquisadora que se tratava de uma situação hipotética, G. aceitou a proposta.

G. listou os convidados de sua festa e registrou essa quantidade com risquinhos, além dos alimentos e bebidas a serem oferecidas. Após o registro escrito desses itens, a pesquisadora sugeriu o cálculo da quantidade de cada item necessário para ser oferecido na festa, como pode ser visto na Figura 11: 


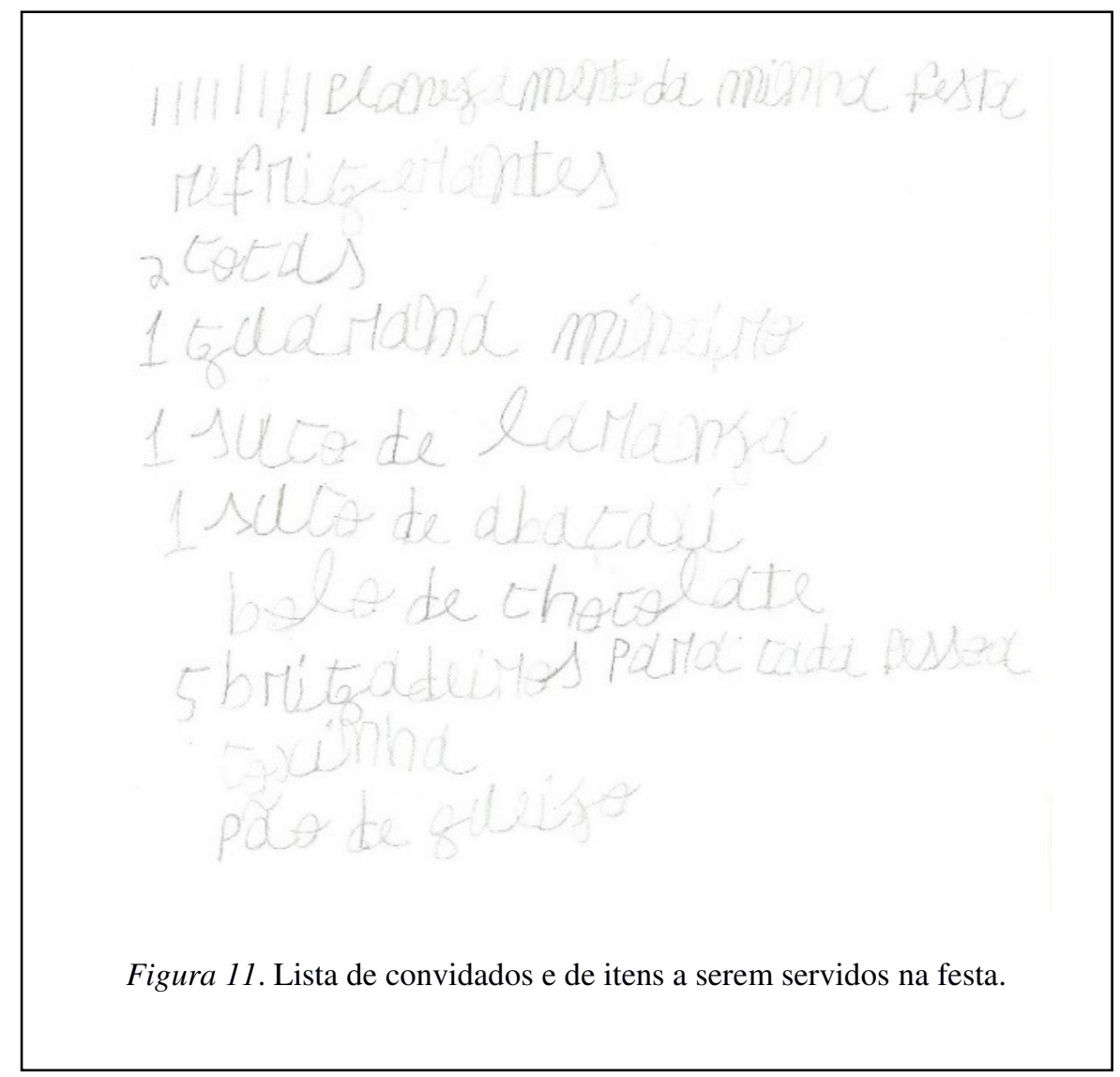

Foi estabelecido por G. que cinco brigadeiros seriam suficientes para cada convidado e a pesquisadora sugeriu uma situação problema referente ao campo conceitual das estruturas aditivas e multiplicativas, caracterizada pela relação entre o número de convidados da festa e a quantidade de brigadeiro a ser servida. Foi necessário que a pesquisadora retomasse, algumas vezes, a situação-problema, pois G. repetiu a fala da pesquisadora, introduziu assuntos paralelos, mas não se engajou de imediato na resolução da situação-problema. O início da resolução da situação-problema foi caracterizado pela verbalização exploratória das possibilidades de resolução:

P: Isso, e como é que a gente descobre o total de brigadeiros que a gente precisa comprar?

G: É, isso aí é outra coisa para pensar. Pensar direito nesse negócio aí. 05 dá 10, não. Ah, não, dá não. Ah, isso aí não é conta não.

P: Eu não entendi. O que você falou?

G: Falei que 05 dá 10 . Não é conta não esse negócio aí. 
A pesquisadora ofereceu a possibilidade de resolução com apoio gráfico. A resolução elaborada por G. consistiu na soma de dez e cinco.

P: Se você quiser tem como resolver essa pergunta por conta também.

G: Pode ser,

P: Como você achar melhor. Aqui tem mais espaço, olha.

G: É. 10 mais 5.5 mais 0 é 5.

P: Uhum.

G: Eu acho que 0 mais 5 não dá. 10 mais 5. 11,12,13,14,15. Dá 15.

P: Uhum, 10 mais 5 dá 15.

A pesquisadora buscou engajar G. no julgamento da razoabilidade do resultado da operação realizada, em face da situação-problema proposta já que, apesar do resultado da operação estar correto, a operação realizada não é compatível com a situação-problema. Para tanto, ela solicitou que G. explicasse a operação realizada, a partir das parcelas que foram somadas:

P: Agora, me diga uma coisa, esse 15 que você achou é o total de brigadeiro que precisa para sua festa?

G: Eu acho que sim, não sei.

P: Que conta é essa que você fez, me explica.

G: Que conta é essa?

P: É. Da onde que você tirou o 10 e o 5.

G: Por causa daqui.

P: Ah, esse 05 aqui é por causa dos 05 brigadeiros para cada pessoa. E o 10 ?

G: E o 10? Para somar quantos brigadeiros vão dar.

A pesquisadora retomou o problema proposto e seus elementos constituintes: o total de brigadeiros a serem comprados em função da quantidade de brigadeiros que seriam servidos para cada convidado, como pode ser observado na transcrição abaixo:

“P: E quanto é que dá todos esses brigadeiros juntos, então? Os 05 de cada uma dessas pessoas?

G: Quantos dá todos os 05?

P: Os 05 brigadeiros de cada uma dessas pessoas aqui.

G: É tem que ver isso.

P: Como a gente pode fazer? São 08 pessoas e cada uma delas vai receber 05 brigadeiros. 
G: 05 mais 05 mais 05 mais 05 mais $05 . "$

A última fala de G. denota uma adição, porém quando procede à resolução da operação, G. utilizou a palavra "vezes" demonstrando que, mesmo intuitivamente, ele faz uma relação entre as operações de adição e multiplicação. Porém, a resolução ocorreu por meio do registro do algarismo cinco, oito vezes, mas G. demonstrou dificuldade quanto à memória operacional já que, por diversas vezes, ao invés de registrar uma parcela com o algarismo cinco, o faz registrando a quantidade de parcelas a ser registrada, como se pode observar na Figura 12. Os algarismos seis e sete referem-se à sexta e sétima parcelas a serem somadas, que deviam conter o número cinco.

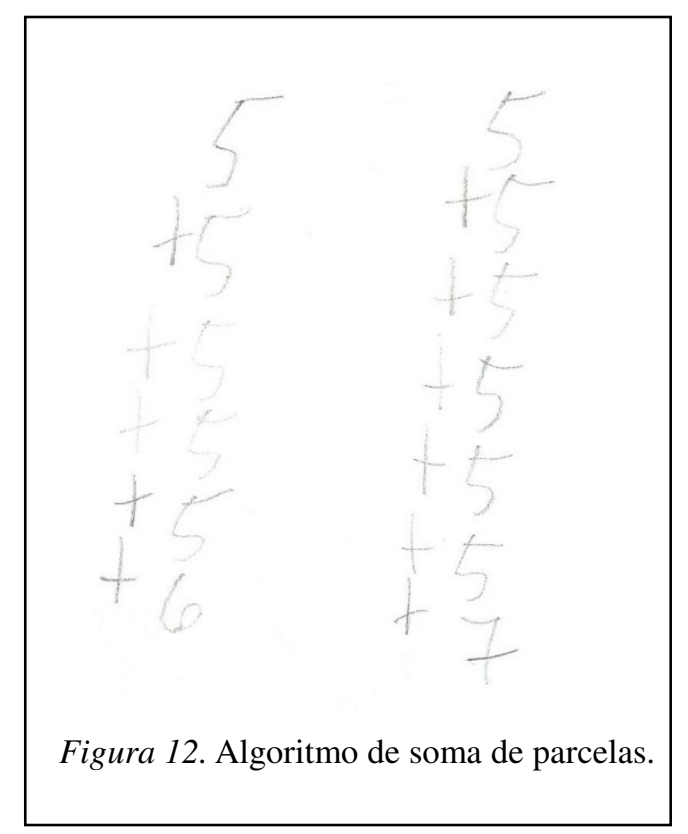

Ao observar que G. estava com dificuldade, a pesquisadora optou por introduzir uma operação de multiplicação, com a intenção de que ele ultrapassasse esse impasse. Porém, G. retornou a sua forma inicial de resolução, buscando, nessa tentativa, apoio em quantidade discreta.

À medida que realizava suas tentativas, ele continuamente falava consigo mesmo, 
como forma de organizar sua ação. Mesmo assim, ele teve dificuldade de realizar um registro com material concreto que fosse compatível com a operação referente à situaçãoproblema e esboçou sinais de cansaço. Esse motivo, associado ao avançar da hora em relação ao tempo previsto para a sessão de intervenção, levou a pesquisadora a interromper a atividade, que deveria ser retomada na sessão subsequente.

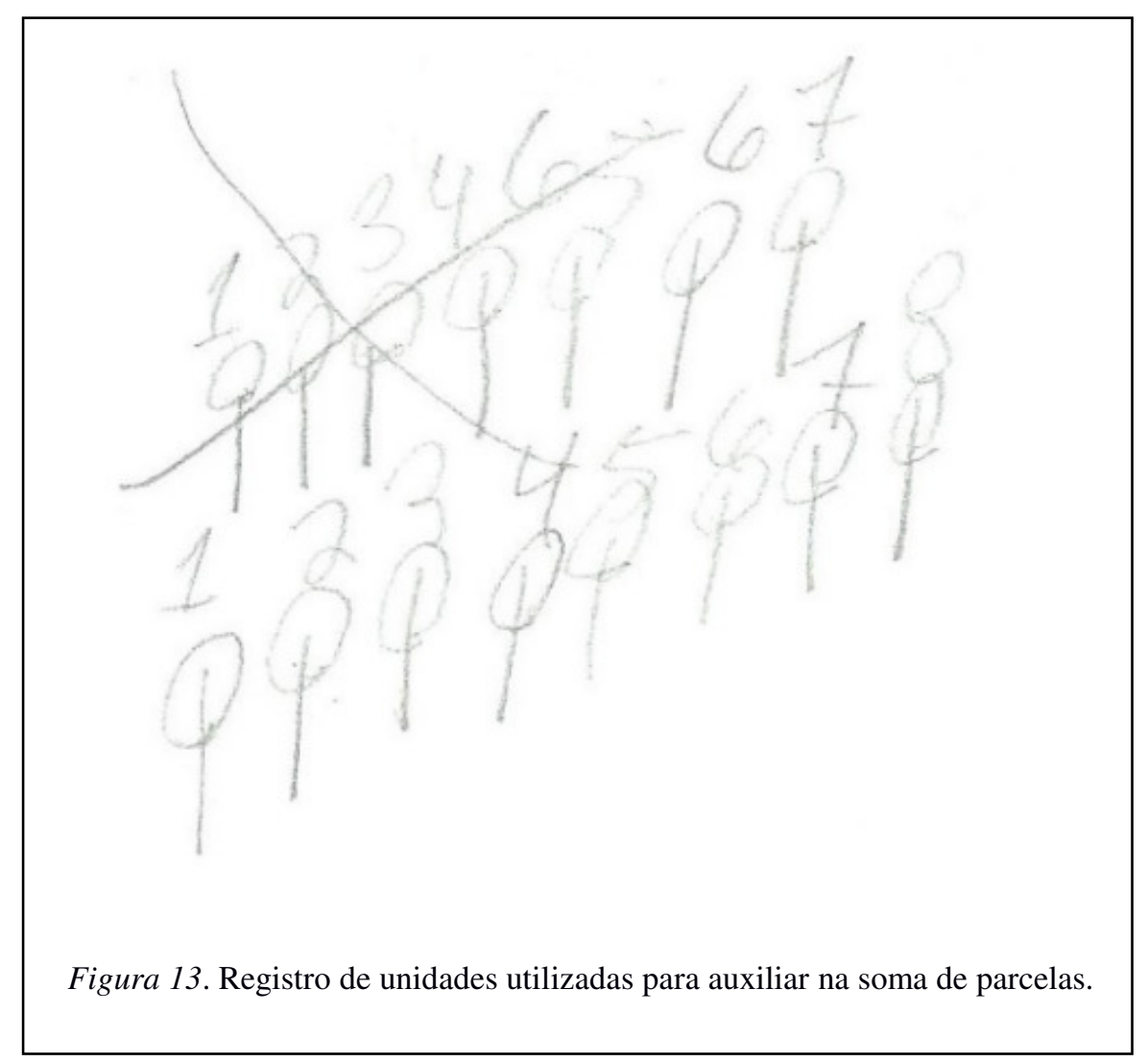




\subsubsection{Nona sessão de intervenção psicopedagógica.}

Data: 27/04/2015 Duração: 41 minutos

Objetivos da sessão: Propor situações-problemas e mediar suas soluções em uso de calendário; mediar a resolução de situações-problemas referentes ao campo conceitual das estruturas aditivas e multiplicativas.

2.4.3.9.1 Desenvolvimento, resultados e discussão da nona sessão de intervenção psicopedagógica.

Nessa sessão de intervenção, foram realizados dois conjuntos de atividades: o primeiro refere-se à exploração do calendário e das situações-problemas de contagem. $\mathrm{O}$ segundo é referente ao planejamento da festa de aniversário, que oportunizou situaçõesproblemas envolvendo o campo conceitual das estruturas multiplicativas. Os materiais utilizados foram: um calendário de mesa, o relógio digital de pulso de G., lápis grafite, folhas de papel sulfite e a lista de itens para o planejamento da festa de aniversário, elaborada na sessão anterior.

G. identificou a data corrente no calendário e também utilizou seu relógio digital como fonte de informação acerca da data. Essa ação pode ter relação com as sessões de intervenção anteriores, em que o uso desse instrumento foi estimulado. Como já registrado anteriormente, o relógio de G. estava com a data atrasada em um dia, mas, quando ele foi informar a data à pesquisadora, ele espontaneamente fez a correção do atraso. Tal ação pode, também, ter relação com as mediações já realizadas.

Como G. ficara doente, em momento anterior à sessão, a pesquisadora propôs uma situação-problema envolvendo a contagem dos dias em que não houve sessões de intervenção. Para tanto, foi sugerido o uso da estratégia, já utilizada em sessões anteriores, 
de destacar o dia de início e fim da contagem, o que foi realizado por G. Em sua primeira tentativa, ele contou todos os dias do mês, não utilizando as marcações feitas para direcionar sua contagem. Isso pode significar que, apesar de dominar os princípios básicos de contagem, como já descrito, o procedimento de contagem de um intervalo, utilizando esse tipo de instrumento - o calendário - ainda não se tornou um esquema solidificado para G.

A pesquisadora buscou auxiliá-lo na análise de seu próprio desempenho, formulando questões sobre o significado do procedimento de contagem realizado. A resposta de G. dá indícios de que ele reproduziu um esquema de contagem sem relação com o contexto da situação proposta:

"P: E quantos dias passaram do dia 06 até o 27 ?

G: $1,2,3,4,5,6,7,8,9,10,11,12,13,14,15,16,17,18,19,20,21,22,23,2,4,25,26,27,28,29$, 30.

P: Isso que você contou foi o quê?

G: Os dias, as semanas."

Tais questionamentos parecem ter sido boas ferramentas para auxiliar G.na análise de seu desempenho, visto que ele verbalizou esquecimento a respeito da questão proposta e engajou-se numa segunda tentativa, interrompendo a contagem quando chegou ao último dia marcado, apesar de não ter começado a contagem a partir do primeiro dia marcado e, sim, do primeiro dia do calendário.

“G: Eita, esqueci desse negócio aí.

P: Vamos tentar de novo?

G: Vamos.

P: Vai lá.

G: 1,2,3,4,5,6,7,8,9,10,11,12,13,14,1,5,16,17,18,19,20,21,22,23,2,4,25,26,27.

P: Hum, você parou aqui no dia 27.

G: É.

P: Você parou no 27 porque?

G: Porque era para contar do 06 até ele." 
Pode ser que G. esteja internalizando esse procedimento de contagem de um intervalo apenas com uma regra sem, entretanto, ter compreendido sua lógica. Tal hipótese embasa-se na resposta elaborada por G. ao questionamento da pesquisadora sobre o motivo de ter interrompido sua contagem no último dia marcado.

Algumas mediações oferecidas pela pesquisadora podiam estar colaborando para tal hipótese, como se pode observar na mediação em relação ao ponto de início da contagem. De forma geral, essa mediação caracterizou-se pela enunciação de uma regra, ao invés da condução à dedução por parte G. Inclusive, a resposta dada por ele era a reprodução da fala da pesquisadora, ocorrida em uma sessão anterior, em que a mesma questão do procedimento de contagem de um intervalo estava em sendo discutida:

"P: Isso. Então tinha que parar no 27. Mas você começou a contar aqui do 01. O 01 valia?

G: Não.

P: Não, o 01, 02, 03, 04, 05 não valia, porque que não valia?

G: Porque já passou.

P: Então a gente tinha que começar a contar do 06. Porque é desse dia para frente que eu quero, até chegar no 27. Começa no 06 e para no 27. Vamos ver quantos dias que dá?"

O segundo conjunto de atividades foi introduzido retomando a questão pendente da sessão de intervenção anterior. Ele era relacionado ao campo conceitual das estruturas multiplicativas, caracterizado por um problema de razão, por meio do cálculo da quantidade de brigadeiros a ser disponibilizado para os convidados:

"P: A gente estava tentando descobrir quantos brigadeiros a gente precisa comprar para a sua festa. E a gente tinha visto, olha, a gente tinha decidido que a gente iria comprar 5 brigadeiros para cada pessoa. Então, para cada pessoa que vai na sua festa, a gente vai comprar 5 brigadeiros. Como é que a gente descobre quantos brigadeiros a gente precisa comprar?"

$\mathrm{Na}$ fase de planejamento da resolução da situação problema, G. buscou a informação faltante no enunciado do problema, referente à quantidade de pessoas a serem 
convidadas para a festa, que havia sido estipulada em oito. Porém, na fase de resolução, ele teve dificuldade em selecionar a operação a ser realizada e utilizou um esquema que pode estar relacionado às intervenções anteriores em que foram explorados agrupamentos em base 10. Além disso, G. parece ter realizado um raciocínio de dividir a quantidade 10 pelos oito convidados:

"G: Quantas pessoas tem mesmo? 1,2,3,4,5,6,7,8.

P: Isso. Então são 8 pessoas que você pensou em convidar e para cada uma delas a gente vai comprar 5 brigadeiros. Quantos brigadeiros que dá no total?

G: $1,2,3,4,5,6,7,8,9,10$. Não, não dá isso tudo não. 5 mais 5 . Também não dá. 5 mais 5 é 10 .

P: 5 mais 5 é 10, isso mesmo. Mas você já descobriu quantos brigadeiros precisa comprar para todo mundo?

G: 10 não vai dar".

A pesquisadora interpôs outro tipo de situação, propondo uma situação de proporção, porém, como já salientado, tal ação parece atrapalhar o desenvolvimento do raciocínio G., o que devia ser evitado em outras sessões. Em seguida, como G. não conseguiu elaborar nenhuma outra estratégia de solução, ela propôs a realização da representação da situação-problema através de um desenho.

G. engajou-se na elaboração do desenho, registrando apenas um brigadeiro para cada convidado. A pesquisadora fez perguntas sobre o registro produzido que levaram G. a perceber a incompletude de seu desenho em relação à situação proposta.

Essa primeira produção de G. e a mediação que foi necessária podem evidenciar que G., sozinho, ainda não possuía esquemas consistentes em relação a esse tipo de situação-problema. Por outro lado, pode-se considerar que tal conhecimento estivesse em fase de aprendizagem ou na zona de desenvolvimento proximal, nos termos vygotskinianos já que, à medida em que ocorria a intervenção, as falas G. denotavam a tomada de consciência a respeito do assunto tratado: 
"P: Essa pessoa aqui tem quantos brigadeiros?

G: 1 .

$\mathrm{P}$ : E quantos brigadeiros a gente pensou que cada pessoa podia ter?

G: 5 .

P: Hum.

G: Ih, é verdade.

$\mathrm{P}: \mathrm{O}$ que foi?

G: É 5.

P: E o que aconteceu aqui no seu desenho?

G: 1 . É verdade.

P: O que você tem que fazer para corrigir?

$\mathrm{G}$ : Desenhar mais.

P: Mais brigadeiros para todo mundo ou só para esse aqui?

G: Para todo mundo.

P: Quantos brigadeiros cada uma dessas tem que ter?

G: 5 .

P: Ah, entendi. Como é que você pode fazer isso então?

G: Desenhar mais"

Ao longo do registro, G. explicitou a intenção de conferir sua produção e, por diversas vezes, utilizou-se da contagem como estratégia de conferência da quantidade de convidados. Ele revelou o uso adequado de tal esquema para a situação, inclusive escrevendo algarismos arábicos para auxiliar nesse controle, como pode ser observado na Figura 14:

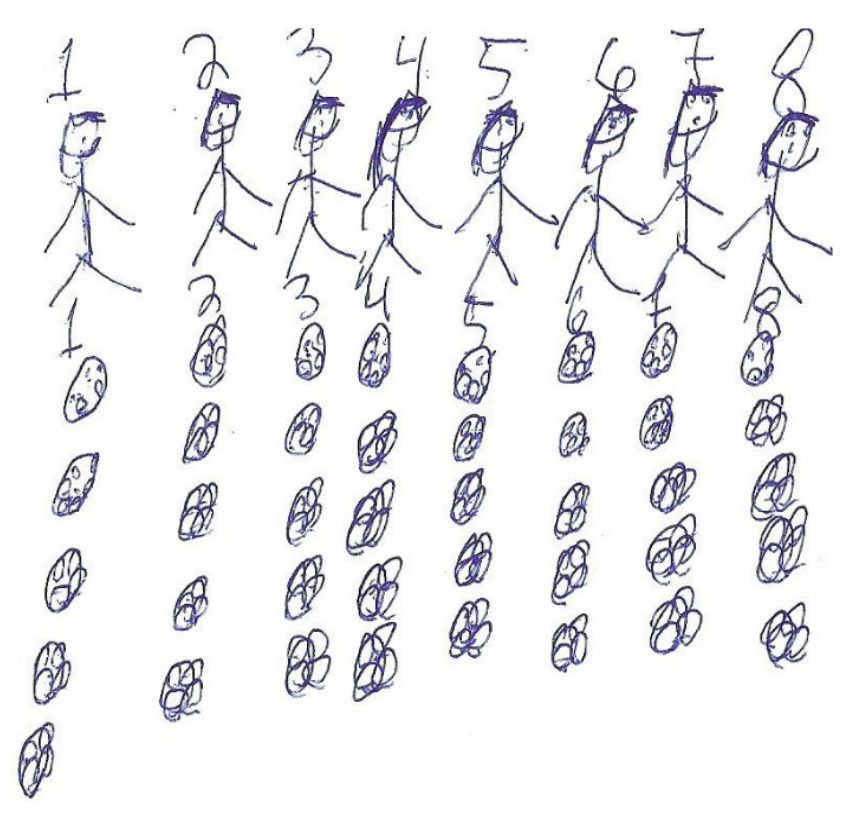

Figura 14. Representação da situação-problema dos brigadeiros. 
Quando concluiu o registro, a pesquisadora retomou a situação do total de brigadeiros e G. procedeu à contagem, sem apresentar dificuldades. A pesquisadora propôs a transposição da situação desenhada para uma operação aritmética, sendo que G. recorreu aos seus conhecimentos de fatos numéricos buscando alcançar o resultado final igual ao encontrado na contagem, sem recorrer, porém, ao desenho. A estratégia utilizada por G. revela que ele não relacionou a ação registrada no desenho à representação com uma operação aritmética.

"P: Excelente. Agora aquela outra coisa que eu te falei. Se você tivesse que pensar em um jeito, sem ser de desenho, usando números, usando uma conta para descobrir esse mesmo tanto, como é que a gente poderia fazer? Para dizer que a gente ia precisar de 5 brigadeiros para cada pessoa, você imagina uma conta que chegaria nesse mesmo resultado?

G: Tem que dar esse mesmo número aqui.

P: É. É a gente transformar o desenho em conta.

G: 40 vezes 1 . Não dá certo.

P: Porque não?

G: Ah não, dá.

P: O que aconteceu, me explica.

G: É que eu estava pensando em outra, só que eu pensei 40 vezes 1.

P: É 40 vezes 1 dá 40.

G: 40 vezes 1,40 dividido por 1 ."

Na ausência de elaboração de outra estratégia de transposição do desenho para uma operação matemática, a pesquisadora ofereceu auxílio, explicitando a possibilidade de utilização de uma operação de adição ou multiplicação, mas, mesmo assim, a relação ainda não foi explícita para ele. Por esse motivo, a pesquisadora mediou o conceito de multiplicação como soma de parcelas e, assim, eles chegam à operação de multiplicação. A seguir, a transcrição da interlocução a respeito e a operação realizada por G. estão apresentadas: 
"P: Usando as coisas que você tem aqui. As 8 pessoas e os 5 brigadeiros de cada 1 . Como faria uma conta de vezes, nesse caso?

G: 40 vezes 5 . Não, não dá não. Deu muito certo não. Estou sem ideia.

P: Olha, vezes é a gente repetir o que a gente fez. O que você fez aí de forma repetida? Várias vezes?

G: Brigadeiro.

P: Isso. Quantas vezes você fez brigadeiros para cada pessoa?

G: 5.

P: Então você desenhou 5 brigadeiros quantas vezes?

G: 40.

P: Aqui, você desenhou 5 brigadeiros 40 vezes?

G:É. Ah, peraí, 8. 1,2,3,4,5,6,7,8.

P: Então você desenhou 5 brigadeiros 8 vezes.

G: É. 1,2,3,4,5,6,7,8. É.

P: Qual conta de vezes representa isso aí que você fez? 8 vezes os 5 brigadeiros.

G: É, pode ser 8 vezes 5.”

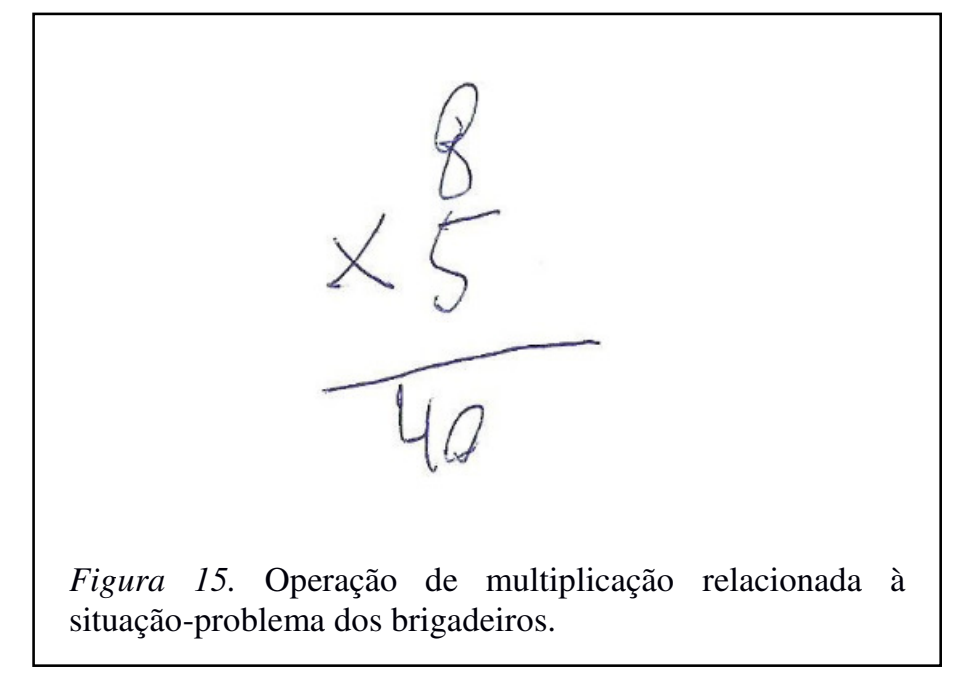

\subsubsection{Décima sessão de intervenção psicopedagógica.}

Data: 04/05/2015 Duração: 59 minutos

Objetivos: Propor situações de reconhecimento das horas, minutos e segundos utilizando relógio analógico e digital; propor situações de reconhecimento da data corrente e proceder a contagem de dias utilizando o calendário; propor o planejamento da festa de aniversário e as situações-problemas referentes ao campo conceitual das estruturas de adição e multiplicação. 
2.4.3.10.1 Desenvolvimento, resultados e discussão da décima sessão de intervenção psicopedagógica.

Essa sessão se desenvolveu em torno de três eixos temáticos: o primeiro referente às situações de identificação da data corrente e da contagem de dias; o segundo relacionado à identificação de minutos e segundos em relógio analógico e o terceiro referente à continuidade do planejamento da festa de aniversário. Esse contexto serviu para que fossem mediadas situações-problemas pertencentes ao campo conceitual das estruturas aditivas e multiplicativas.

Como ocorreu na sessão anterior, G. informou a data corrente, corrigindo a data registrada em seu relógio digital de pulso. Tal ação reiterada pode ser consequência das mediações ocorridas durante as sessões de intervenção. G. expressou a consciência da necessidade de atualizar a data de seu relógio, utilizando a palavra "adiantado", ao invés de "atrasado", o que pode indicar uma compreensão fragmentada dos conceitos envolvidos nas situações de comparação de tempo.

Durante a manipulação do calendário para a localização da data corrente, G. referiu que uma data destacada em cor diferente se tratava de um feriado, sem associar a informação disponível a esse respeito na região inferior da página do calendário. Diante da situação "Tem alguma coisa que a gente tem que fazer para achar o dia 04 do mês de maio ou você já achou? ", G. procurou nas páginas do calendário o mês em questão, o que demonstra a compreensão do registro dos meses em páginas diferentes. Ambas as situações, identificação do registro do feriado e procurar uma data específica, podem ser consideradas como um desenvolvimento de G. se comparadas às situações anteriores.

A pesquisadora propôs uma situação de contagem dos dias que já haviam passado do mês em curso, sendo que G. conseguiu realizar tal contagem sem dificuldade, 
respeitando todos os princípios de contagem. A diferença dessa situação de contagem usando o calendário divergia das demais situações vivenciadas por haver coincidência entre o início da contagem e o início dos dias do mês em questão.

O segundo eixo da sessão focou o registro do tempo nos seguintes relógios: relógio de pulso digital, relógio digital grande de mesa, relógio analógico pequeno com marcação dos segundos e relógio analógico grande sem marcação dos segundos. G. demonstrou familiaridade com as situações de identificação de horas e minutos tanto no relógio analógico como no digital, demonstrando conhecer a composição de horas e minutos, apesar de não dominar o princípio multiplicativo sob o qual repousa o funcionamento do relógio analógico. Foi proposto, pela pesquisadora, que G. registrasse por escrito a formação de minutos pelos segundos. Todavia, quando foi proceder tal registro, em vez de escrever sobre o aspecto mencionado, G. registrou que uma hora é formada por sessenta minutos. Tal dado é relativo a um conhecimento anterior de G., que não foi mediado na sessão.

A mediação da compreensão dos agrupamentos sucessivos dos segundos em minutos e minutos em horas foi feita predominantemente de forma expositiva e caracterizada pela interação do tipo perguntas e respostas. Esse procedimento pode não ter sido eficaz e se aproxima às situações de avaliação escolar. A consideração dessa possibilidade proporcionou a tomada de consciência pode parte da pesquisadora e foi considerada no planejamento das sessões de intervenção seguintes, buscando outras formas de interação que propusessem atividades através das quais G. pudesse se desenvolver.

Nessa intervenção, a introdução do terceiro eixo foi mediada pela retomada de memória em relação à sessão anterior acerca de qual atividade estava sendo realizada. G. retomou a atividade realizada e reproduziu a fala da pesquisadora, referente à oferta de 
suco para os participantes que não gostassem de refrigerante. Contudo, ele não retomou a operação de cálculo da quantidade de brigadeiros a serem servidos na festa. Esse dado pode ser interpretado como um indicativo da habilidade de G. em memorizar informações verbais para uso posterior, como já observado em situações anteriores, como a da composição das horas pelos minutos.

A continuação da atividade de planejamento da festa de aniversário se deu pelo cálculo da quantidade de coxinhas e pães de queijo em função do número de convidados. O estabelecimento da quantidade de coxinhas a ser considerada para cada convidado foi realizado a partir de uma estimativa baseada na suposição de G. sobre quantas coxinhas cada pessoa comeria numa festa, conforme pode ser observado na transcrição da interlocução a seguir:

"P: A gente decidiu que a gente ia comprar 5 brigadeiros para cada pessoa. Quantas coxinhas a gente compra para cada pessoa? O que você acha? Quantas coxinhas as pessoas comem durante a festa?

G: Ixi. Vou ter que pensar.

P: Então vamos pensar. A gente pode pensar assim. Uma coisa que as pessoas comem muito, a gente tem que comprar?

G: Muito.

P: Uma coisa que as pessoas comem pouco, a gente compra pouco. Você acha que coxinha, as pessoas comem muito ou pouco?

G: Acho que pouco. Não sei.

P: Quantas mais ou menos?

G: Uma ou duas."

A pesquisadora propôs uma situação-problema semelhante à situação explorada na nona sessão de intervenção psicopedagógica, isto é, determinar quantos alimentos deveriam ser comprados em função do número de convidados da festa. Entretanto, nesse caso, a situação era referente à quantidade total de coxinhas que deveria ser comprada. Na fase de planejamento da operação a ser realizada, a verbalização G. pode indicar um raciocínio relacionado a uma estrutura distributiva, ou seja, parece ter pensado em 
distribuir cinco coxinhas para os oito convidados da festa - sendo que essa quantidade seria remanescente da situação do brigadeiro. G. concluiu que a quantidade de coxinhas não é suficiente para a quantidade de participantes. A transcrição da interlocução é apresentada a seguir:

"P: É, eu gosto muito de coxinha, quando o recheio é com catupiry então, hum.

$\mathrm{G}$ : Eu gosto também.

P: Pois é, quantas será que a gente compra?

G: Pode ser, vai ter muitas pessoas, pode ser. Cinco não dá para oito."

O fato de a pesquisadora ter mencionado anteriormente a situação dos brigadeiros, como forma de auxiliar na estimativa da quantidade de coxinhas, pode ter contribuído para a inclusão da informação da situação do cálculo do brigadeiro na situação do cálculo da coxinha. A pesquisadora utilizou, então, a estratégia de relacionar a estimativa da quantidade para a vivência de G. instigando-o a considerar a quantidade de coxinhas que ele considera que comeria numa festa. A quantidade referida por G. foi duas coxinhas. Dessa forma, com a quantidade de coxinhas definidas, G. engajou-se em raciocínio de outra natureza, característico das estruturas multiplicativas, a partir da soma de parcelas:

"P: 2. Então para cada pessoa da sua festa a gente vai comprar 2 coxinhas. G: É.

P: Pode ser? Então, como é que a gente descobre o total de coxinhas que a gente vai precisar comprar?

G: Duas coxinhas, duas coxinhas

P: Isso, isso para cada pessoa.

G: Dois mais dois. Dois mais dois dá quatro."

A dificuldade de G. na resolução dessa situação-problema pode ser explicada pelo fato de haver duas situações problemas em jogo: era necessário estabelecer quantas coxinhas cada pessoa comeria e o total de coxinhas. A pesquisadora o auxiliou a continuar desenvolvendo o raciocínio iniciado, verbalizando a soma por ele iniciada, oito vezes, uma 
para cada convidado da festa e mencionou, também, que essa foi a estratégia utilizada para a resolução da situação do brigadeiro. Diante disso, G. propôs a realização de um desenho, tal como feito anteriormente.

Durante a realização do desenho, a pesquisadora e G. engajaram-se numa conversa relacionada a comentários humorísticos sobre o desenho, planejamento do desenho e comentários avaliadores da produção realizada. Por sugestão da pesquisadora, foi adicionado o nome de cada convidado.

Ao iniciar o registro da quantidade de coxinhas referente a cada convidado, G. não lembrava a quantidade acordada anteriormente e ofereceu um palpite de que seriam quatro coxinhas. A pesquisadora informou a quantidade acordada e G. procedeu ao registro de duas coxinhas para cada convidado, sem nenhuma dificuldade procedimental a esse respeito. Por sua opção, incluiu algarismos abaixo de cada coxinha para auxiliar o procedimento de contagem do total de coxinhas desenhadas.

A pesquisadora propôs a continuação do planejamento da festa de aniversário por meio do cálculo da quantidade de pães de queijo a serem servidos para cada convidado e a proposta de G. foi oferecer quatro pães de queijo para cada convidado. Tal quantidade havia sido introduzida por ele na interação em que se desejava relembrar quantas coxinhas seriam servidas. Essa parece ser a mesma característica registrada anteriormente, em que G. introduz, numa situação atual, informações referentes a situações anteriores, de natureza semelhante, mas sem que essa informação seja necessariamente indispensável ao contexto em questão.

Outro dado que se repetiu foi o fato de G. novamente ter reproduzido a fala da pesquisadora, a qual ocorreu há duas sessões anteriores, referentes à necessidade de disponibilizar mais alimentos para que as pessoas tenham possibilidade de escolher a 
quantidade que desejam comer. A repetição desse tipo de dado pode indicar uma maior apropriação de G. em relação ao contexto da intervenção, visto que os conceitos mediados têm estado envoltos num contexto que parece ter despertado o interesse de G. Nas primeiras sessões de intervenção, em que o contexto de mediação referia-se à manipulação de palitos, tal repetição não ocorreu.

A pesquisadora interveio sugerindo que fosse utilizado o mesmo desenho já iniciado para realizar o registro da situação-problema dos pães de queijo, assim como a mesma estratégia de mediação. G. engajou-se na realização do registro das quantidades de quatro pães de queijo para cada participante sem nenhuma dificuldade procedimental e procedeu à conferência numérica das quantidades registradas. Os registros dos quatro pães de queijo foram realizados, sendo dois posicionados numa linha e dois numa linha logo abaixo, conforme pode ser observado na Figura 16.

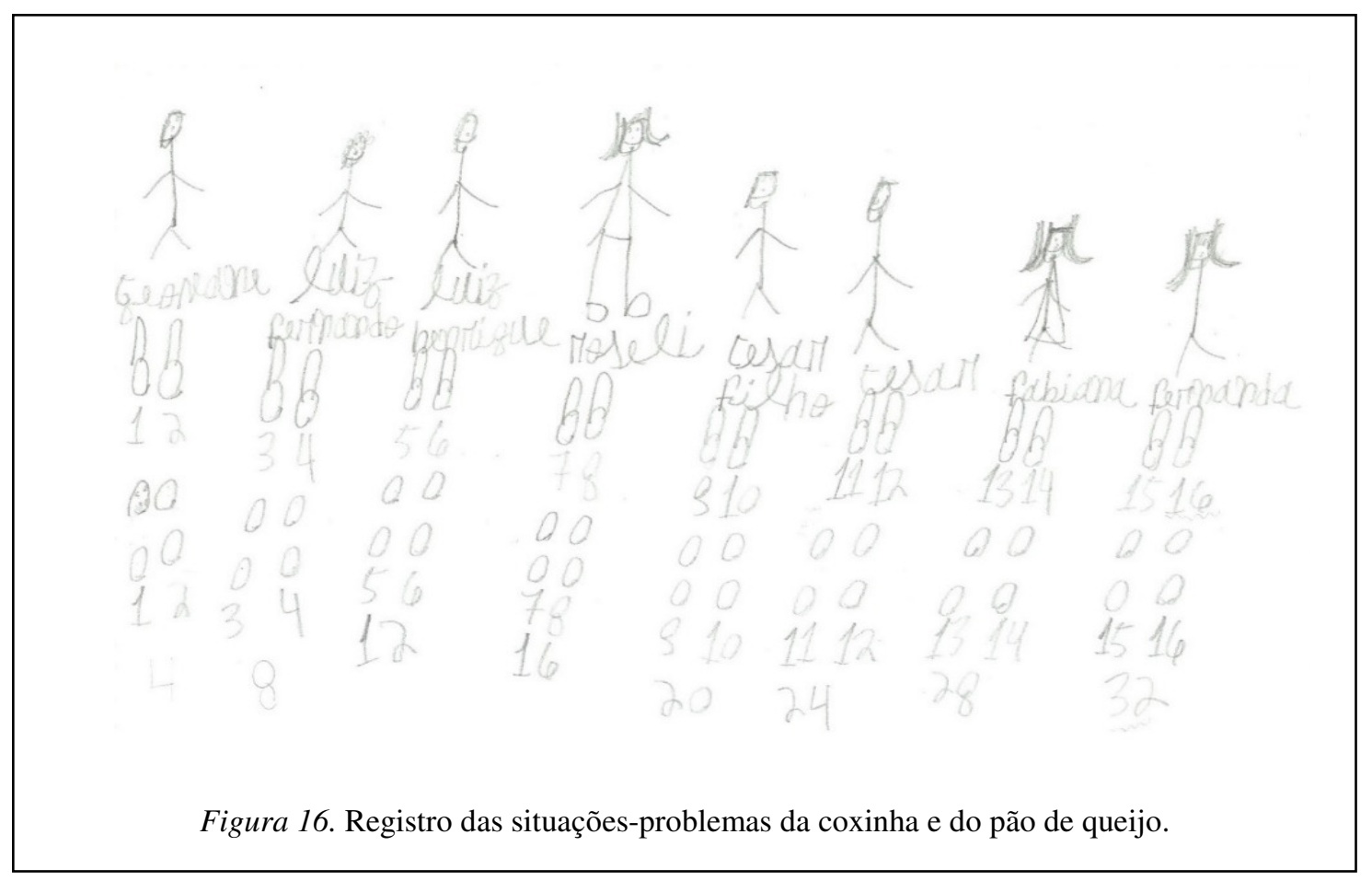

Apesar de ter registrado a quantidade correta de pães de queijo em relação à 
solicitação da situação-problema, ao calcular o total de pães de queijo, G. contou apenas os desenhos de pão de queijo posicionados na segunda linha. Seu procedimento de contagem seguiu adequadamente os princípios e serviu inclusive como preditor do resultado, pois à medida que sua contagem se aproximava do final, G. relatou a expectativa de que a quantidade de pães de queijo seria igual à da coxinha.

Essa questão remete àquela relacionada à percepção visual e pode-se pensar que a proximidade entre a primeira linha de pães de queijo desenhada e os demais desenhos realizados possa ter dificultado a percepção visual dos elementos a serem considerados na contagem. Desempenho semelhante foi observado na primeira e segunda sessão de intervenção psicopedagógica nas quais, apesar de também demonstrar capacidade de realizar a contagem, o desempenho de G. sofreu modificação quando as quantidades a serem contadas foram apresentadas sem organização espacial.

Essa hipótese significa que, pelo menos nesse tipo de situação, a dificuldade do estudante não tem origem no pensamento matemático, mas esse pode ter sofrido interferência da questão perceptual ao longo do processo de desenvolvimento e escolarização de G. Significa também que a apresentação dos materiais a serem utilizados com G. é relevante para seu desempenho, o que tem importantes implicações educacionais.

A pesquisadora buscou oferecer uma comparação da quantidade de coxinhas e pães de queijo, registrando para apenas um convidado e esperava que G. transferisse essa lógica para o total dos conjuntos. Porém, de forma geral, inicialmente a mediação da pesquisadora para auxiliar G. a transpor tal dificuldade foi no sentido de expor a impossibilidade de tal resultado e apenas solicitou a confirmação por parte de G. do entendimento acerca de sua explanação.

G. verbalizou sua percepção da inadequação da resposta por ele oferecida - a da 
igualdade de quantidade entre coxinhas e pães de queijo - dizendo que "essa aqui não está OK”. Tal verbalização pode estar revelando que G. compreende a situação de resolução de situações-problemas como a busca de respostas corretas e participa da interlocução com a pesquisadora, confirmando suas solicitações, como uma forma aprendida de lidar afirmativamente quando lhe questionam se compreendeu uma situação.

Na sequência, ela recorreu a estratégias matemáticas. A primeira delas foi solicitar que G. contasse o total de pães de queijo, sendo que ele o fez, considerando as duas linhas de desenhos realizados, mas esquecendo-se de contar um elemento. A pesquisadora não interveio nesse sentido, pois considerou que esse não era o aspecto mais importante naquele momento.

A segunda estratégia foi solicitar que G. registrasse abaixo de cada pão de queijo da primeira linha a continuação da contagem iniciada na segunda linha, porém a pesquisadora abandonou essa estratégia, já que ao registrar, G. retornou seu esquema inicial de considerar apenas a segunda linha dos pães de queijo desenhados. Dessa forma, a pesquisadora propôs uma terceira estratégia que consistiu no registro da contagem do total de pães de queijo em base quatro, a cada convidado, sendo que G. a realizou sem dificuldades (ver figura 16).

Após esse registro, a pesquisadora questionou G. sobre a quantidade anteriormente contada por ele, referindo-se à contagem em que se esqueceu de um elemento e chegou à quantidade 31. G., porém, remeteu-se a primeira contagem em que chegou à quantidade 16 - mesma quantidade das coxinhas. Buscando não mais confrontar G., a pesquisadora não o questionou a respeito.

A pesquisadora propôs ainda o cálculo da quantidade total de alimentos a serem oferecidos na festa, auxiliando G. a considerar todas as quantidades já estabelecidas: as dos 
brigadeiros, das coxinhas e dos pães de queijo. Apesar de inicialmente se mostrar reticente, a pesquisadora estimulou G. a tentar e ele iniciou a resolução, confundindo-se, porém, no registro da quantidade de coxinhas, que seriam 16 e ele registrou 15 . G. observou seu equívoco e se corrigiu, iniciando uma nova operação.

G. procedeu à resolução da operação de adição de forma convencional, posicionado corretamente os algarismos segundo seu valor posicional, iniciou a resolução pelas unidades e alternou entre a soma mental e o uso de apoio em quantidades discretas nos dedos. Ao final da intervenção, G. participou do planejamento da próxima sessão, lembrando-se que ainda faltaria calcular a quantidade de bebidas e de bolo.

\subsubsection{Décima primeira sessão de intervenção psicopedagógica.}

Data: 11/05/2015 Duração: 35 minutos

Objetivos: Propor situações problemas que envolvem noções de unidades de medida; propor situações de contagem de unidades apresentadas numa organização espacial não linear; propor a produção de registros gráficos, utilizando a representação de unidade de medida.

2.4.3.11.1 Desenvolvimento, resultados e discussão da décima primeira sessão de intervenção psicopedagógica.

Nessa sessão, foi dada continuidade à situação de planejamento da festa de aniversário, sendo que esse assunto foi introduzido com a pesquisadora mostrando para G. que ela havia trazido uma garrafa de refrigerante conforme a lista produzida na nona sessão de intervenção. Tratava-se de uma garrafa de refrigerante de cola de dois litros e meio cheia de água e com o rótulo preservado. Também foram usados copos plásticos brancos de $200 \mathrm{ml}$, uma bandeja redonda de 14 cm de diâmetro, folhas de papel sulfite e lápis grafite. 
A pesquisadora indagou à G. qual sua ideia sobre a presença desse refrigerante na sessão e ele disse considerar que era "para medir". Referiu também que já havia vivenciado uma situação assim previamente, mas não soube dar detalhes. Vale ressaltar que nas interações com a pesquisadora não houve menção a isso.

Aproveitando a menção de G. sobre medida, a pesquisadora questionou quanto de água ele considerava que caberia dentro daquela garrafa. A primeira resposta de G. não teve relação com as unidades de medida convencionais, pois ele afirmou que a garrafa estava cheia "quase até o final".

A pesquisadora instigou G. a buscar no rótulo da garrafa alguma informação a respeito de sua capacidade e G. identificou a informação no rótulo. Ele demonstrou reconhecer a representação "2,5 l” como uma unidade de medida de capacidade.

G. realizou a leitura dessa unidade de medida de duas formas diferentes. $\mathrm{Na}$ primeira vez fez uma leitura literal do texto como "dois vírgula cinco litros". A segunda leitura foi "dois litros e meio", sendo que essa mudança de leitura foi espontânea, o que pode significar experiências anteriores com a leitura dessa unidade de medida.

A situação de cálculo de refrigerante foi colocada pela pesquisadora que questionou se G. considerava que uma garrafa como aquela seria suficiente para os oito convidados da festa. G. realizou uma operação mental de proporção entre a quantidade de líquido e a quantidade de pessoas, demonstrando relacionar que quanto maior a quantidade de pessoas, maior a quantidade de líquido necessário.

"P: A gente sabe que essa garrafa cabe dois litros e meio de Coca. Você acha que uma garrafa dessa é suficiente para oito pessoas? Ou será que a gente vai ter que comprar outras garrafas de Refrigerante de cola?

G: Acho que vai ter que ser outra porque oito pessoas é muito.

P: É. São muitas pessoas ou é muito líquido?

G: É muita pessoa." 
A pesquisadora propôs uma situação-problema questionando quantos copos seriam cheios com a quantidade de líquido da garrafa. Ela dispôs uma quantidade de copos sobre a bandeja para evitar que água caísse sobre a mesa, durante sua manipulação, e novos copos foram acrescentados à medida que ainda havia líquido na garrafa. G. encheu os copos com ajuda da pesquisadora enquanto a garrafa estava muito pesada e deu continuidade à atividade de modo independente, à medida que o peso da garrafa diminuiu.

Quando a água da garrafa acabou, a pesquisadora retomou a situação da quantidade de copos que aquela quantidade de líquido encheria (15). G. engajou-se, então, num procedimento de contagem dos copos. Ele respeitou o princípio da ordem estável, relação biunívoca e cardinalidade durante a contagem, mas teve dificuldade em realizar o controle dos copos já contados e dos copos que ainda deveriam ser contados. Apesar de não descrever explicitamente essa dificuldade, ele relatou confusão em relação a seu procedimento de contagem. A pesquisadora questionou o que G. considerava que estava o confundindo e sua resposta denota que ele estava buscando determinar quais copos já havia sido contados, identificando-os com números, mas sua estratégia não foi eficiente para a situação em questão, como pode ser observado na transcrição abaixo:

"P: O que você acha que está te confundindo?

G: Esse aqui é o um, esse aqui é o dois. Um dois, três, quatro, cinco, seis, sete, oito, nove, dez, onze, doze, treze, quatorze, quinze, dezesseis."

Esse dado remete novamente à questão da percepção visual que foi citada nas sessões anteriores. Há dados para afirmar que G. é capaz de realizar a contagem com essa mesma quantidade e a dificuldade que foi observada tem relação com a apresentação das unidades a serem contadas numa distribuição espacial que não delimita um ponto de início e de fim para a contagem. A pesquisadora propôs a disposição dos copos numa linha reta 
sendo que, com os copos dispostos dessa forma, G. conseguiu realizar a contagem adequadamente, ou seja, ele contou os quinze copos que haviam sido enchidos.

A pesquisadora apresentou outra situação-problema, agora referente à divisão da quantidade de copos cheios pela quantidade de convidados da festa. Ela questionou como poderia ser feita essa divisão. G. respondeu "um de cada vez", e explicou seu procedimento de divisão: "Vou beber esse aí. Aí meu pai bebe esse e meu irmão bebe esse".

G. foi estimulado pela pesquisadora a proceder à divisão como ele propôs e o fez deslocando um copo para cada convidado nomeado e formando uma fileira de copos dispostos um ao lado do outro. Assim, ainda havia sete copos a serem distribuídos, que G. destinou aos convidados que quisessem servir-se novamente. A pesquisadora o instigou a continuar a divisão e G. repetiu o mesmo procedimento de distribuição de copos pelos convidados, dispondo-os atrás dos copos já enfileirados, conforme sugestão da pesquisadora. As ações G. demonstram que ele compreende o conceito de divisão enquanto distribuição, utilizando material manipulável em situação contextual.

Ao final do segundo procedimento de divisão, os copos estavam organizados em duas fileiras, sendo que cada item da fileira correspondia aos copos de um dos oito convidados da festa. As unidades de cada fileira estavam posicionadas imediatamente uma em frente à outra, mas a segunda fileira, contava com sete copos, visto que se tratou de uma divisão de 15 por 8. Ao observar tal disposição, G. referiu que sobrou um copo.

A pesquisadora questionou se sobrou ou se faltou um copo. Por esse motivo, G. mudou sua resposta dizendo que faltou copo. Depois, a pesquisadora percebeu que eles estavam operando sobre lógicas diferentes, ou seja, ele estava falando que sobrou um copo sem seu par correspondente na organização das fileiras e ela estava falando que faltou um copo para completar a segunda fileira. 
A pesquisadora solicitou que G. realizasse um registro da atividade realizada e pediu para que ele a verbalizasse. G. disse "Dois litros e meio dá para encher quinze copos" e produziu um desenho representativo de sua fala, conforme a Figura 17. À medida que foi realizando seu desenho, G. registrou também algarismos numéricos como forma de controle da quantidade de copos desenhados.

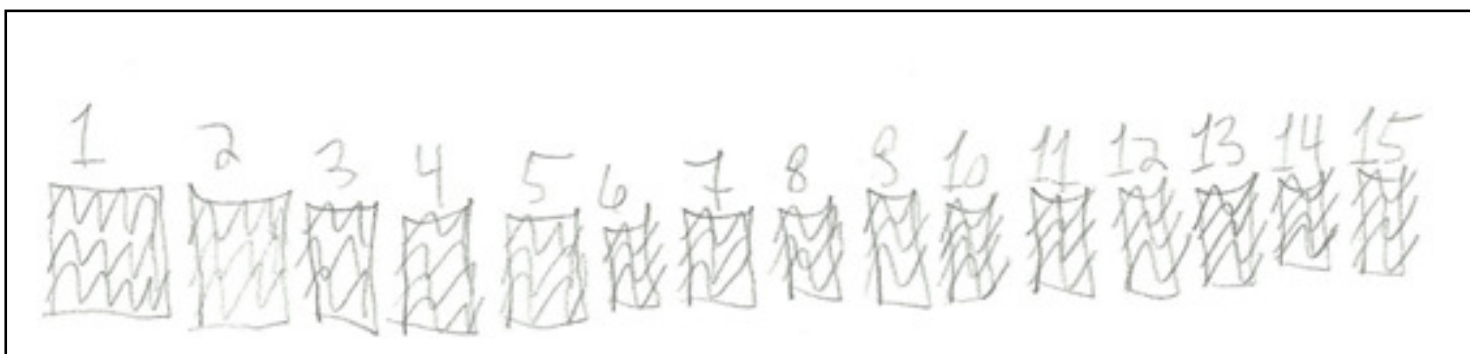

Figura 17. Registro da quantidade de copos que podem ser enchidos com 2,5 1 de água.

Para a próxima sessão, planejou-se retomar a situação da apresentação dos copos cheios numa disposição circular, ou seja, sem delimitação explícita de um ponto para o começo e o fim da contagem, a partir do cálculo de quanto de refrigerante será servido para os convidados. Porém, dessa vez, será oferecido a G. a possibilidade de realizar marcações nos copos já contados, com objetivo de verificar se essa estratégia auxilia em seu desempenho.

Na análise do extrato referente à décima primeira sessão de intervenção (Tabela 8), pôde-se perceber a diferença nos atos da fala de que G. lançou mão, destacando-se os atos da fala que são da esfera da avaliação, ou seja, que expressam um julgamento de valor ou uma apreciação e da esfera acional, que propõem o fazer, que incitam e exortam o fazer e o engajamento. Nota-se também que à medida que esses atos da fala se tornaram preponderantes, diminuíram as falas que se caracterizavam pela repetição da fala da pesquisadora. 
Observou-se, portanto, que o desenvolvimento ocorreu não apenas para o participante, mas também para a pesquisadora, num processo de tomada de consciência, sendo, nesse caso, um processo intencional, de regulação ativa (Fávero, 2000, 2001 conforme citado por Fávero \& Couto Machado, 2003), que foi promovido, em grande parte, pelo próprio método de intervenção psicopedagógica, que preconizava a análise e a reflexão de cada uma das sessões de intervenção.

\section{Tabela 8}

Análise dos atos da fala retirados da décima primeira sessão de intervenção

\section{Transcrição dos atos da fala Esferas dos atos da $\quad$ Categorias dos atos da fala fala}

Situação de encher copos plásticos com água, representando refrigerante, para posterior contagem, com objetivo de verificar quantos copos uma garrafa de refrigerante encheria.

P: Então vamos ver quantos copos desse daqui uma Acional Agir garrafa dessa dá para encher?

G: Vamos.

P: Você quer que eu te ajude?

G: Pode ser. Eita poxa, está pesado mesmo.

Avaliação

Avaliar

P: É, não é? Eu vou segurar com você.

G: Tá.

P: Segura e eu seguro junto. Pronto. Então um copo de Refrigerante de cola, faz de conta, não é, porque essa Refrigerante de cola aqui é...

G: Sem cor. Refrigerante de cola branca.

Informação

Informar

P: Transparente.

G: É, transparente.

P: Olha, vou só arrumar os copos aqui, para os que ainda estão vazios ficarem mais perto. Veja se você consegue sozinho já colocar.

G: Qual está vazio, esse? É, esse. É. Um por vez, aí. Agora esse aqui. Mais um ou dois. Essa aqui está Avaliação

Avaliar quase. Estou parecendo um garçom. Eita. Agora vai ser difícil saber qual está cheio e qual está vazio.

P: Você quer ficar de pé para você conseguir olha dentro do copo?

G: Pode ser. Ixi. Aquele ali está cheio, aquele também, 
aquele ali de trás, esse aí, esse aí, aquele está mexendo também. Esse aqui está cheio? Está cheio. Eu vi ele tremendo agora.

P: Muito bem, então com dois litros e meio de Coca, a gente encheu esses copos aí.

G: É. Olha, deu para encher muito.

P: É, quantos copos deu para a gente encher com dois litros e meio de Coca?

G: Vê os que estão balançando aqui que é mais fácil. Um, dois, três, quatro, cinco, seis, sete, oito, nove, dez, onze, doze, treze.

P: Enchemos treze?

G: Acho que sim, fiquei confuso.

$\mathrm{P}: \mathrm{O}$ que você acha que está te confundindo?

G: Esse aqui é o um, esse aqui é o dois. Um dois, três, quatro, cinco, seis, sete, oito, nove, dez, onze, doze, treze, quatorze, quinze, dezesseis.

P: Ixi, deu diferente, não é?

G: É.

P: Você acha que se a gente arrumar os copos de um outro jeito fica mais fácil de contar?

G: Acho que fica.

P: Que tipo de jeito fica mais fácil de contar?

G: É, isso aí vai ter que ter uma ideia.

P: Posso te dar uma sugestão e você me diz se você gosta? Você acha que quando arruma assim, olha, um do ladinho do outro, é mais fácil de contar?

G: É, bem mais fácil.
Informação

Informar

Acional

Agir

Avaliação

Avaliar

Informação

Informar

Informação

Informar

\subsubsection{Décima segunda sessão de intervenção psicopedagógica.}

Data: 18/05/2015 Duração: 32 minutos

Avaliação

Avaliar

Objetivos: Propor situações-problemas referentes ao campo conceitual das estruturas de divisão como medida; propor situações de contagem de unidades apresentadas numa organização espacial não linear, com apoio para o controle das unidades contadas; propor a produção de registros gráficos utilizando a representação de unidade de medida de forma convencional e pessoal. 
2.4.3.12.1 Desenvolvimento, resultados e discussão da décima segunda sessão de intervenção psicopedagógica.

Nessa sessão, a atividade realizada consistiu na continuidade da situação de medida da quantidade de líquido, iniciada na décima primeira sessão de intervenção. Foi utilizada uma garrafa de refrigerante de guaraná de 2 litros, cheia de água, com rótulo preservado, uma garrafa vazia de refrigerante de cola de 2,5 litros, uma bandeja redonda de 14 centímetros de diâmetro, copos plásticos brancos de 200 mililitros e canetas permanentes que escrevem em plástico.

A pesquisadora discorreu a respeito das duas garrafas, lembrando que na sessão de intervenção anterior foi realizada uma atividade de medida sobre quantos copos uma garrafa de refrigerante de cola encheria e que a atividade de hoje seria semelhante à anterior, mas usando a garrafa de guaraná. A pesquisadora chamou a atenção de G. para a diferença de capacidade entre as duas garrafas e propôs uma comparação acerca de qual das duas garrafas caberia mais refrigerante para ser servido às pessoas da festa. G. identificou a garrafa de refrigerante de cola como a que possuía maior capacidade.

Ao tentar calcular a diferença de capacidade existente entre as duas garrafas, G. disse "Essa aqui tem dois litros e meio do que essa", o que significa que G. operou um processo perceptual adequado de comparação entre quantidades contínuas e teve dificuldade em traduzir essa percepção em operações matemáticas para calcular a diferença. G. já havia tido dificuldade em situações envolvendo o conceito de "a mais", utilizando quantidades discretas, conforme registrado no item 2.2 Avaliação do conhecimento numérico.

Ao ser proposta a situação do cálculo da quantidade de copos possíveis de ser 
enchidos com a garrafa de refrigerante de guaraná, G. sugeriu a repetição do procedimento de encher os copos, como realizado com a garrafa de refrigerante de cola, evidenciando a atribuição do significado de medida para tal procedimento. G. encheu os copos com a ajuda da pesquisadora, posicionando-os sobre a bandeja redonda, retomando a organização espacial dos copos como ocorreu na décima primeira sessão de intervenção. Foi possível o enchimento completo de onze copos e meio, pois G. derrubara uma quantidade de água sobre a bandeja.

A pesquisadora retomou a situação-problema proposta acerca da quantidade de copos que poderiam ser enchidos, ao passo que G. verbalizou dúvida se deveria contar o copo que não estava cheio. A proposta da pesquisadora foi contar inicialmente apenas os copos cheios. G. contou quatorze copos, realizando a contagem com a mesma característica observada na décima primeira sessão de intervenção, ou seja, teve dificuldade em realizar o controle das unidades contadas e ainda não contadas, o que denota dificuldade perceptual.

A pesquisadora ofereceu à G. o uso de canetas permanentes para realizar algum tipo de marcação nos itens já contados. Para realizar tal registro, G. pegou um copo de cada vez, separando-o dos demais posicionados na bandeja e, à medida que registrou os algarismos arábicos, na sequência convencional, posicionou os copos fora da bandeja, de forma linear, conforme Figura 18. Tal procedimento permitiu que ele realizasse a contagem de forma adequada, pois suplanta a dificuldade perceptual na contagem com as unidades dispostas de forma circular. Como se pode ver, o décimo segundo copo não foi numerado.

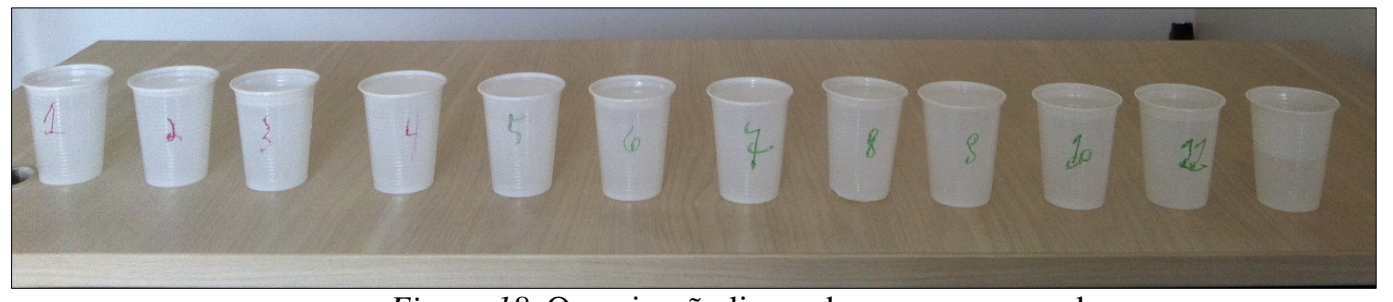

Figura 18. Organização linear dos copos numerados. 
G. explicou a diferença de resultado entre o primeiro e o segundo procedimento de contagem, conforme problematização apresentada pela pesquisadora, referindo ter "faltado contar alguns", o que indica que ele soube dizer que houve diferença no resultado como efeito de diferença no processo de contagem, apesar de não descrever corretamente o que causou essa diferença. A pesquisadora sugeriu o registro da atividade realizada e G. optou por produzir um registro escrito, dizendo sobre a quantidade de copos que foram possíveis de serem completamente enchidos. G. verbalizou "E esse pela metade, que é doze, mas esse aqui não conta, ele ficou pela metade". Essa fala indica que G. estava considerando cada copo cheio como uma unidade a ser contada, não podendo contar o décimo segundo copo, pois ele não estava cheio. G. estava operando, portanto, dentro do conjunto dos números naturais.

Apesar de não seu um objetivo estabelecido a priori para a sessão, a pesquisadora aproveitou a situação e buscou estimular G. a operar dentro do conjunto de números racionais, visto a presença desse conteúdo na série escolar em curso. Para tanto, solicitou que G. registrasse com números a quantidade de copos completamente cheios e o copo cheio até a metade. Ela relembrou a leitura que G. havia feito da capacidade da garrafa de refrigerante de cola de 2,5 litros, dizendo que o algarismo cinco representava a metade, assim como o meio copo cheio. Apesar de G. ter realizado a representação numérica 11,5, a partir do direcionamento da pesquisadora, não há indícios de que ele tenha compreendido tal representação.

Entretanto, pode-se afirmar que G. percebeu a insuficiência da forma numérica "11" para representar os copos cheios e o meio copo, revelando que, apesar de não compreender 
a forma numérica de representação, a percepção da situação foi adequada. No registro pictográfico realizado, G. desenhou onze copos cheios e um copo cheio até a metade, seguindo a numeração por ele realizada, conforme pode ser observado na Figura 19.

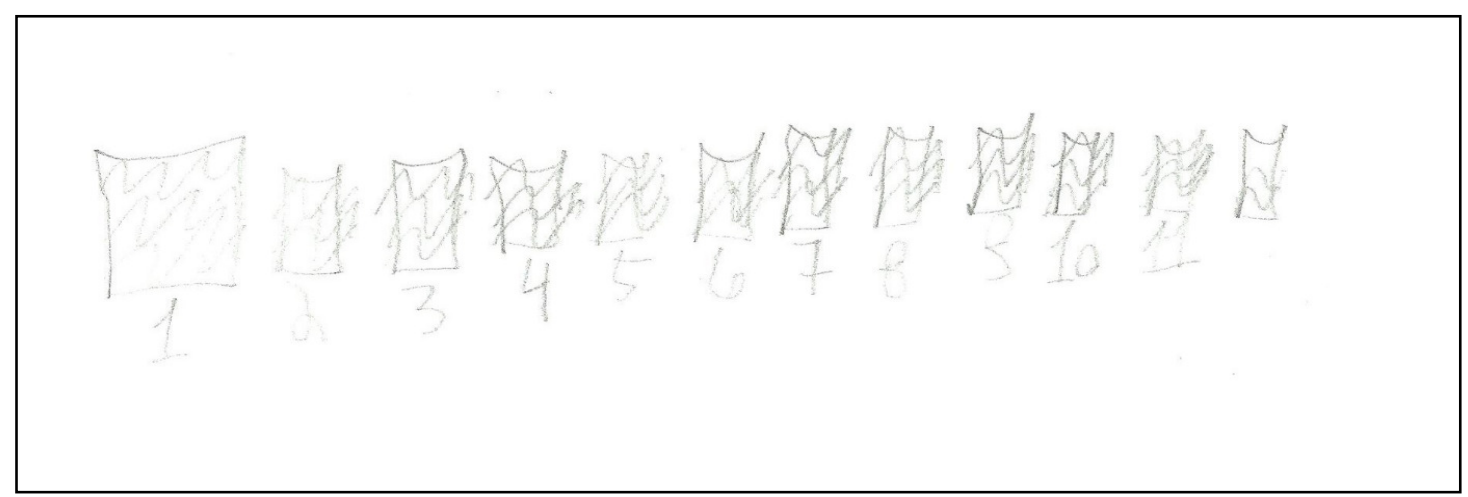

Figura 19. Registro sobre o enchimento dos copos.

Na sessão de intervenção seguinte, a proposta seria a de uma situação-problema que utilizasse as representações produzidas sobre as capacidades das garrafas de refrigerante de cola e de refrigerante de guaraná, para descobrir a capacidade de uma garrafa de suco, inicialmente sem utilizar o transvasamento de líquido.

\subsubsection{Décima terceira sessão de intervenção psicopedagógica.}

Data: 01/06/2015 Duração: 20 minutos

Objetivos: Obter dados sobre a impressão do participante acerca de seu processo de aprendizagem durante as sessões de intervenção; apresentar situações- problemas referentes ao campo conceitual da multiplicação e divisão; propor situações de seriação.

2.4.3.13.1 Desenvolvimento, resultados e discussão da décima terceira sessão de intervenção psicopedagógica.

Essa sessão foi desenvolvida em torno de três eixos de atividade. O primeiro eixo 
foi relacionado com a solicitação de que G. relatasse suas impressões sobre sua aprendizagem nas sessões de intervenção desenvolvidas até aquela data; o segundo eixo foi relacionado às situações-problemas a respeito do cálculo da quantidade de copos possíveis de ser enchidos com uma garrafa de suco, seguida da divisão da capacidade da garrafa de suco pelo número de convidados da festa e o cálculo de quantas garrafas seriam necessárias para servir os convidados. O terceiro eixo foi relacionado com a comparação e seriação em função da capacidade das garrafas de refrigerante de cola, refrigerante de guaraná e de suco.

Nessa sessão, foram utilizados os seguintes materiais: garrafa de refrigerante de cola, garrafa de refrigerante de guaraná, garrafa de suco de uva de vidro transparente, registros anteriores da quantidade de copos possíveis de ser enchidos com as garrafas de refrigerante de cola e de refrigerante de guaraná, gravador, bandeja, registros em desenho dos convidados para a festa, recortados unitariamente e protegidos com papel adesivo transparente.

Antes do início da sessão, a pesquisadora e G. estavam conversando sobre as atividades que ele tem realizado na Sala de Recursos de sua escola. Ele relatou que estava aprendendo sobre contas e estudando inglês. Dando continuidade a essa conversa, a pesquisadora apresentou a questão relacionada às descobertas que G. tem empreendido nas sessões de intervenção. Para tanto, ela perguntou o que G. diria se seu amigo, um dos convidados da festa de aniversário, perguntasse o que ele tem aprendido nessas sessões. As respostas de G. se caracterizaram mais pela descrição de resultados das vivências, do que dos processos desenvolvidos: "Contaria que estou aprendendo a fazer contas de divisão, mais e menos", "Que tem uma conta que eu esqueci o nome que dá 100" e "Teve dos copos também. 11 copos e 1 pela metade”. 
A pesquisadora apresentou a garrafa de vidro e perguntou à G. se ele considerava se seria possível encher mais ou menos copos com aquela garrafa, em relação às garrafas de refrigerante. G. respondeu que seria possível encher menos copos, pois havia mais espaço entre a superfície do líquido e o final do gargalo da garrafa de vidro do que havia nas garrafas de refrigerante, que foram apresentadas cheias de água até o final do gargalo. Essa resposta denota que G. relacionou o conceito de espaço e de capacidade.

Para a situação de cálculo de quantos copos seriam possíveis de encher com a garrafa de suco, a pesquisadora inicialmente apresentou a situação-problema e em seguida solicitou que G. distribuísse os copos sobre a bandeja. Para tanto, ela ofereceu os copos um dentro do outro, de forma que G. teve que manipular os copos um por um para posicionálos sobre a bandeja. A intenção era que G. se engajasse numa contagem da quantidade de copos antes de enchê-los, em função das situações anteriores em que ele teve dificuldade de contá-los quando apresentados numa disposição circular. Porém, G. não realizou a contagem espontaneamente.

G. se orientou pelo movimento da água para contagem dos copos cheios, como realizado nas sessões anteriores. Novamente ele teve dificuldade de estabelecer a relação biunívoca quando os copos estavam apresentados em disposição circular, como ocorreu na décima primeira sessão de intervenção. A diferença é que nessa situação havia oito copos a serem contados e na décima primeira sessão havia 15 copos a serem contados, de forma que foi mais fácil para G. se corrigir na consideração de todas as unidades a serem contadas. Esse dado tem relação com a hipótese de dificuldade perceptual já mencionada nas discussões das sessões anteriores, visto que a quantidade de estímulos e, principalmente, sua apresentação, parecem dificultar o desempenho de G. em situações de contagem.

A pesquisadora apresentou os desenhos dos convidados e propôs a seguinte questão: 
"Se a gente tem essas pessoas aqui e esses copos de suco, dá para todo mundo beber um copo de suco, sobra ou falta?" Vale ressaltar que não é presente no enunciado qual tipo de operação deve ser utilizada para a resolução da situação.

G. utilizou-se de uma divisão colocando um copo em frente de cada desenho dos convidados, retomando um procedimento já vivenciado em situações anteriores. Porém, havia um desenho muito próximo a um outro e G. não o considerou durante a distribuição dos copos, de modo que sobrou um copo sobre a bandeja e um convidado sem copo. G., porém, ofereceu uma resposta contextualizada ao enunciado da questão, afirmando que sobrou um copo. Ele afirma "8, sobrou 1 copo".

Visando levar G. a perceber que havia um convidado sem copo, a pesquisadora questionou à que se refere o 8 que G. contou. Inicialmente ele respondeu que se tratava da quantidade de copos, porém, ao realizar uma contagem de conferência, ele percebeu que tinha apenas sete copos sobre a mesa, cada um direcionado a um convidado. G. então mudou sua resposta e contou a quantidade de convidados (8).

A pesquisadora retomou então as informações disponíveis até aquele momento: haviam oito convidados e sete copos distribuídos sobre a mesa, sendo que, dessa forma, G. concluiu que faltaria um copo. Em seguida, a pesquisadora chamou atenção para o copo disponível sobre a bandeja, mas como G. não havia ainda notado que havia um convidado sem copo, ele não considerou a possibilidade de distribuí-lo também. Assim, a pesquisadora apontou a relação de cada convidado com um copo. Ao chegar ao convidado sem copo, G. percebeu a ausência da correspondência e distribuiu o último copo.

Mais uma vez, esse dado retoma a hipótese de dificuldade perceptual como elemento dificultador prevalecente, já que, G. demonstrou compreensão da situação e do procedimento de sua resolução, mas teve dificuldade em se organizar perante os estímulos 
presentes.

Ao chegar à conclusão que uma garrafa de suco era suficiente para encher 8 copos, de forma que cada convidado pudesse tomar um copo de suco, a pesquisadora questionou quantas garrafas de suco seriam necessárias se cada convidado quisesse beber dois copos de suco. G. respondeu essa questão, afirmando serem necessárias duas garrafas de suco, sem precisar de nenhum tipo de apoio para resolução, ou seja, ele demonstrou competência para realizar uma operação de multiplicação mentalmente.

O último procedimento dessa sessão foi a seriação das garrafas em função da quantidade de copos que elas eram capazes de encher. Para tanto, a pesquisadora apresentou os registros anteriores feitos em relação à capacidade da garrafa de refrigerante de cola, 15 copos, e de refrigerante de guaraná, 11 copos e meio. G. realizou a seriação, relacionando apenas dois elementos de cada vez, o que pode indicar um desenvolvimento ainda inicial desse tipo de operação mental. Para a confirmação de tal hipótese, outras situações semelhantes deviam ser propostas. .

$\mathrm{Na}$ sessão seguinte, o planejamento era apresentar situações envolvendo noções monetárias, de forma a poder relacionar conceitos já vivenciados, como o de numeral racional, operações matemáticas, contagem e seriação.

\subsubsection{Décima quarta sessão de intervenção psicopedagógica.}

Data: 08/06/2015 Duração: 44 minutos

Objetivos: Propor situações-problemas envolvendo noções do sistema monetário (nomeação de cédulas e moedas, seriação de cédulas a partir do seu valor); propor e desenvolver as atividades de intervenção de modo a instigar o participante a participar das interlocuções. 
2.4.3.14.1 Desenvolvimento, resultados e discussão da décima quarta sessão de intervenção psicopedagógica.

A pesquisadora informou à G. que nessa sessão havia uma brincadeira de faz de conta, em que ele seria o dono de uma confeitaria, onde seria comprado o bolo de aniversário para Geovane, um amigo da pesquisadora. Essa proposta foi estabelecida para buscar oportunidades de interação diferentes das geralmente estabelecidas nas sessões de interação, caracterizadas pela díade pergunta-resposta. G. participou do jogo de faz de conta, atuando no papel de vendedor. Estavam disponíveis três imagens de bolo de aniversário, etiquetas, lápis grafite, folha de sulfite, cédulas de dois, cinco, dez, vinte, cinquenta e cem reais sem valor monetário e moedas de plástico de cinco, dez, vinte e cinco, cinquenta centavos e um real, coloridas, sem relação entre a cor e o valor representado pela moeda.

Para o início das atividades, a pesquisadora sugeriu que G. organizasse as cédulas, moedas e estabelecesse preço para os bolos, podendo ele escolher entre determinar o valor do bolo inteiro ou de cada pedaço. Na atividade de organização das cédulas, $\mathrm{G}$. as nomeou corretamente pelo seu valor e, ao seriá-las, a partir das cédulas de menor valor, para as cédulas de maior valor, organizou a seguinte sequência: $R \$ 2,00, R \$ 5,00, R \$ 20,00$, $\mathrm{R} \$ 50,00, \mathrm{R} \$ 100,00$ e $\mathrm{R} \$ 10,00$. Para a sessão de intervenção seguinte, planejou-se verificar qual a lógica utilizada por G. para posicionar as cédulas de 10 reais ao final da série.

G. também reconheceu as moedas a partir de seu valor, mas ao organizá-las, o fez a partir do critério de cor e não pelo valor representado pela moeda. Diante desse dado, planejou-se, para a sessão de intervenção seguinte, modificar o material utilizado, optandose pelo uso de moedas verdadeiras, correntes em nosso sistema financeiro. Ao estabelecer 
o preço dos bolos, G. registrou o valor de cada bolo utilizando a representação convencional do sistema monetário, com o uso de vírgulas e do nome "reais" para referirse aos valores utilizados por ele.

G. estabeleceu $\mathrm{R} \$ 3,00$ como o preço de um bolo inteiro e $\mathrm{R} \$ 20,00$ como o preço de uma fatia de outro bolo. A pesquisadora, atuando como cliente da loja, buscou engajar G. numa atividade reflexiva sobre a incongruência relativa entre o preço dos dois bolos, mas G. justificou o preço do bolo mais barato da seguinte forma: "Eu estou vendendo barato porque ele não é muito caro". Essa resposta demonstra que G. não utilizou um conhecimento numérico para avaliar o tamanho relativo do número e explicar a relação de preços entre os bolos.

A pesquisadora verbalizou que desejava comprar o bolo mais barato e G. apontou o bolo que custava $\mathrm{R} \$ 3,00$, como o mais barato. A pesquisadora fez o pagamento utilizando duas moedas de 25 centavos, uma moeda de 50 centavos e duas moedas de 1 real. G., ao receber as moedas, leu o valor correspondente de cada uma, mas não as somou formando um todo. Ele contou as cinco moedas que recebeu, demonstrando ter considerado a quantidade discreta de moedas recebidas, em vez de seu valor.

Numa nova situação de compra de bolo, G. apontou o bolo mais barato entre as opções restantes, mesmo sem ter havido solicitação a respeito, demonstrando reproduzir a interação anterior. $\mathrm{O}$ bolo em questão custava $\mathrm{R} \$ 4,00$ cada pedaço. A pesquisadora solicitou o valor total da compra, caso comprasse oito pedaços, quantidade de convidados para a festa de aniversário de G., estabelecida por ele em sessão anterior.

A primeira ação de G. foi repetir o dado do enunciado referente à quantidade de convidados. Na sequência, enunciou a sequência numérica até oito. A pesquisadora considerou que G. estava com dificuldade em estabelecer a relação entre os dados do 
enunciado e o repetiu, sinalizando que desejava saber o valor da compra de oito pedaços de bolo, a quatro reais cada.

G. realizou uma operação de adição, somando os números do enunciado do problema e resolvendo corretamente o algoritmo, apesar de que ele não era adequado à situação-problema em questão. G. elaborou uma resposta verbal, na qual acrescentou a palavra "reais", após o número, e considerou parte decimal da representação do sistema monetário na escrita, demonstrando compreensão da natureza da resposta procurada, como pode ser observado na Figura 20.

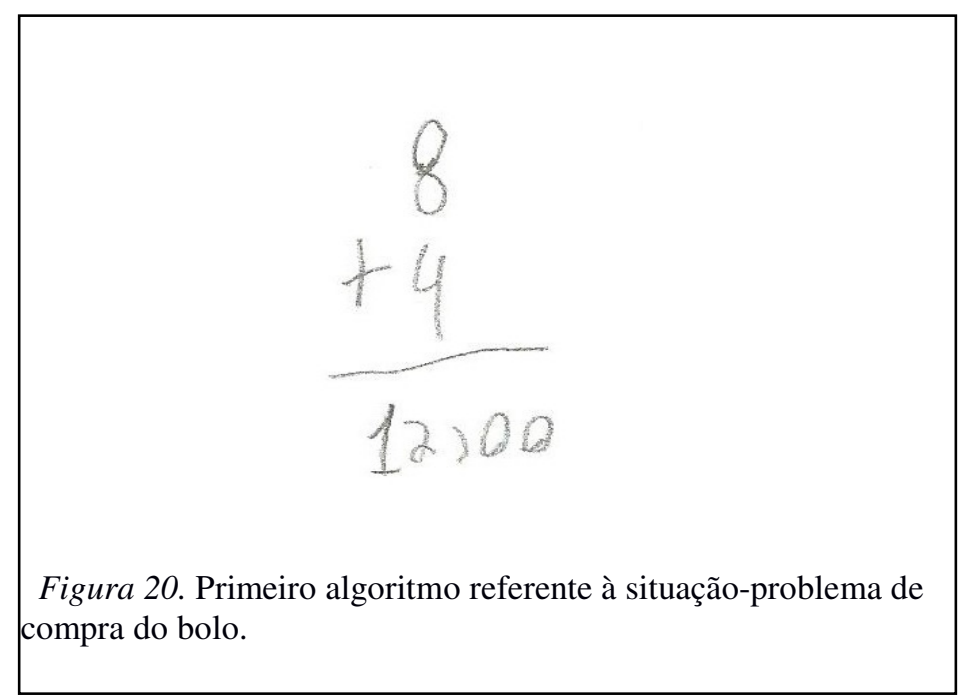

A pesquisadora sugeriu que G. elaborasse uma representação gráfica dos pedaços de bolo a serem comprados e o auxiliou na resolução da situação-problema, enunciando o valor de cada pedaço e solicitando o valor de todos os pedaços juntos. G. inicialmente manteve sua resposta, 12 reais, mas na sequência, passou a considerar a resolução da situação-problema como uma multiplicação, conforme demonstra a transcrição da interação reproduzida a seguir:

"P: Faz de conta que você está fazendo os 8 pedaços para mim. São 8 pedaços que eu preciso, senão algum convidado vai ficar sem.

G: $1,2,3,4,5,6,7,8$. 
P: Esse pedaço me custa 4 reais, esse pedaço me custa 4 reais, esse pedaço me custa 4 reais, esse também, esse também, esse também, esse também e esse também. E quanto é que dá tudo isso aí junto? Todos esses 4 reais juntos?

G: Dá 12. Esses 4 reais? 4 mais 4 mais 4 mais 4.8 vezes. 1,2,3,4,5,6,7,8. Quantos pedaços vai dar isso aí? Vai dar. 8 mais 4 é 12. 1,2,3,4,5,6,7,8."

Aproveitando que G. utilizou a palavra "vezes" em sua fala, a pesquisadora buscou auxiliar sistematizando a operação, sendo que G. produziu um registro que evidenciou um raciocínio referente a uma soma de parcelas, mas o sinal utilizado foi de multiplicação, conforme apresenta a Figura 21:

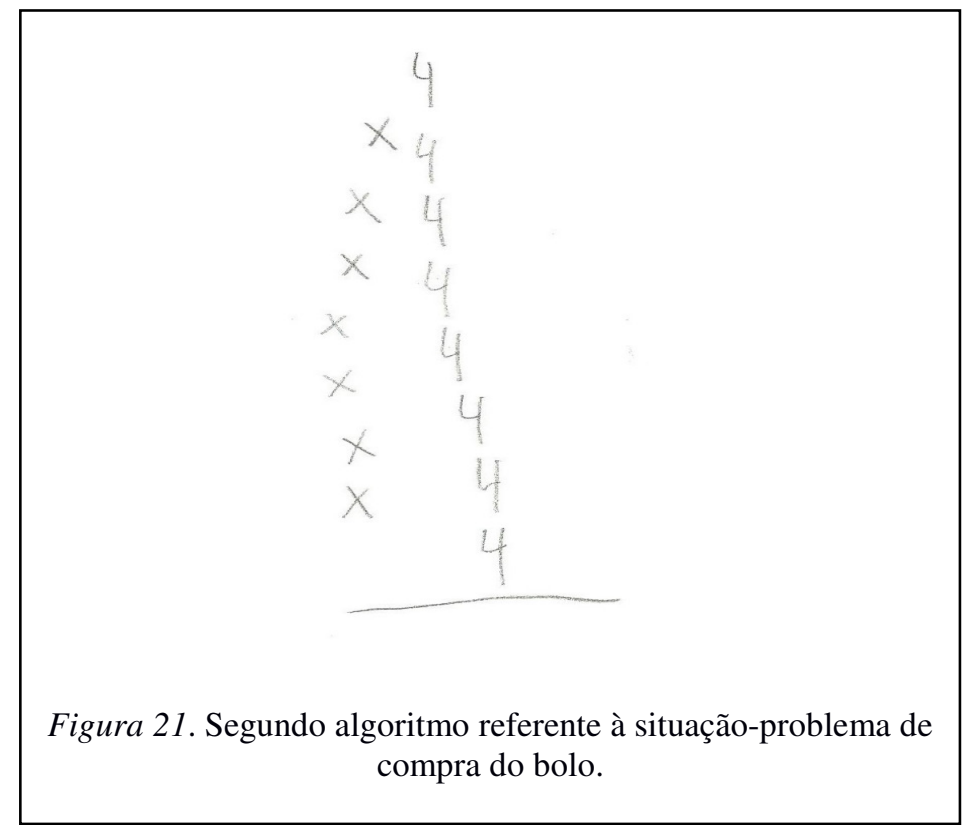

G., portanto, teve dificuldade em operar dentro do campo conceitual das estruturas aditivas e multiplicativas para a resolução da situação-problema de compra de várias fatias de bolo. Esse tipo de situação-problema seria retomado em sessões de intervenção posteriores.

A pesquisadora sugeriu que G. registrasse o valor de cada pedaço de bolo junto aos pedaços já desenhados e solicitou o cálculo do total do valor. G. registrou o algarismo 4 
acima de cada pedaço de bolo desenhado e tentou resolver a soma oralmente: "G: 4 mais 4, 8, mais 4 dá 16, mais 4 dá 30. Dá 30, dá. Não sei. 4 mais 4 dá 8 . Vai dar 40. ”

A pesquisadora optou por não confrontar a resposta oferecida por G. e ofereceu o pagamento da compra com uma nota de $\mathrm{R} \$ 50,00$. G. entregou à pesquisadora três moedas de um real como troco. Percebe-se que G. reconhece o valor das cédulas e moedas, mas não opera com esse conhecimento em situações de cálculo monetário.

Considera-se que o uso do jogo simbólico como forma de proporcionar outras formas de interação contemplou o objetivo da sessão, pois G. demonstrou interesse na brincadeira e prazer em sua realização. Para as próximas sessões, a pesquisadora pretendia manter essa estratégia.

\subsubsection{Décima quinta sessão de intervenção psicopedagógica}

Data: 08/06/2015 Duração: 44 minutos

Objetivos: Propor situações-problemas de seriação e agrupamento de cédulas monetárias e moedas, a partir do critério de valor; retomar a situação-problema do campo conceitual das estruturas multiplicativas, desenvolvida na sessão anterior, com modificação do material de apoio para resolução, com a finalidade de verificar se essa mudança auxiliaria no desempenho do participante.

2.4.3.15.1 Desenvolvimento, resultados e discussão da décima quinta sessão de intervenção psicopedagógica.

Para o desenvolvimento dessa sessão de intervenção, foram utilizadas cédulas monetárias sem valor, de 2, 5,10, 20, 50 e 100 reais, moedas correntes reais de 5, 10, 25, 50 e 1 reais, tanto de material dourado como prateado, imagens recortadas e plastificadas dos 
convidados da festa desenhadas por G. na décima sessão de intervenção, folha A4 e lápis grafite.

A pesquisadora retomou o contexto da festa de aniversário e, assim como na sessão anterior, propôs que G. assumisse o papel de dono de uma loja de confeitaria, onde seria comprado o bolo para a festa de aniversário. A pesquisadora entregou cédulas para G. de forma desorganizada e sugeriu que G. as organizasse, sendo que ele o fez agrupando as cédulas de mesmo valor.

A pesquisadora sugeriu que G. organizasse as cédulas numa série considerando o valor. Durante a organização da série, G. questionou se deveria seguir uma ordem crescente ou decrescente e a pesquisadora deixou essa decisão a critério dele. G. optou por realizar uma série decrescente. À medida que essa atividade foi se desenvolvendo, G., por várias vezes, repetiu para si mesmo esse critério de seriação, provavelmente como forma de auxiliar seu próprio pensamento.

G. estabeleceu que as notas de 100 possuíam o maior valor e continuou a organização das demais cédulas, comparando-as com as notas de cem, em vez de estabelecer relações com as notas de valor intermediário. O desempenho de G. nessa atividade demonstra que ele não estabeleceu uma relação decrescente entre as cédulas intermediárias.

A pesquisadora retirou as cédulas de $20,10,5$ e 2 reais da série que G. havia elaborado e solicitou que ele avaliasse desse subconjunto, qual era a maior cédula. G. apontou a cédula de 20 reais como a de maior valor e tal estratégia foi repetida, sucessivamente, até G. completar a série com todas as cédulas. Ao final dessa atividade, G. havia produzido a seguinte série com as cédulas: 100, 50, 20, 2, 5, 10, ou seja, as cédulas de 2 e de 10 reais estavam violando o critério de ordem decrescente. A pesquisadora 
realizou a leitura da série organizada e G., ao perceber que dois não pode ser considerado maior que cinco, já que estava operando dentro do conjunto dos números naturais, modificou sua organização.

A pesquisadora solicitou que G. também realizasse a leitura da série produzida, visando que ele observasse o posicionamento equivocado da cédula de 10 reais. G realizou a leitura sem estabelecer relação entre as cédulas intermediárias, mas apenas comparandoas à primeira cédula da série: "Cem é maior do que cinquenta, do que vinte, do que cinco, do que dois e do que dez".

Na sequência foi proposta uma atividade de organização das moedas. G. organizou as moedas segundo o seu valor e sua cor, ou seja, organizou conjuntos separados para as moedas de 5,10 e 25 centavos douradas e prateadas. A pesquisadora solicitou que G. buscasse algum grupo para inserir as moedas de cinco centavos prateadas e ele sugeriu juntá-las ao grupo de moedas de 50 centavos, que também eram prateadas.

Tal ação revela que G. estava utilizando prioritariamente o critério de cor para organizar as moedas, em vez de considerar seu valor. Considerando essa hipótese, a pesquisadora pergunta para G. se ele está organizando as moedas pela cor. G. nega que esteja usando esse critério e aponta o grupo de moedas de cinco centavos douradas. Assim, a pesquisadora levou G. a deduzir que o critério a ser utilizado nessa situação é o do valor das moedas:

"P: Mesmo sendo de cor diferente pode ficar junto?

G: Não. Acho que pode, não pode?

$\mathrm{P}$ : Pode, porque o que elas tem de igual?

G: O valor."

A próxima atividade desenvolvida foi a retomada da situação-problema já explorada na sessão anterior. Dessa vez, porém, a pesquisadora ofereceu o apoio nas 
figuras dos convidados da festa desenhados por G. na décima sessão de intervenção. A situação-problema dizia respeito ao valor total da compra de oito pedaços de bolo, cada um custando quatro reais.

G. desenhou um pedaço de bolo para cada convidado e, no momento de estabelecer o valor dos pedaços de bolo, ele considerou que cada pedaço seria um bolo diferente, com um valor diferente. Tal pensamento pode ter relação com a atividade desenvolvida na décima quarta sessão de intervenção, em que havia várias imagens de bolo e cada um com um preço diferente. Pode ter relação também com o fato de que, nessa sessão, foi apresentada uma imagem de um bolo inteiro e G. deveria mentalmente, considerar que cada pedaço desenhado para cada convidado seria um pedaço desse mesmo bolo, o que implicaria num raciocínio relacionado ao conjunto dos números racionais.

Após intervenção da pesquisadora de que cada pedaço desenhado custava o mesmo valor, G. tentou resolver a situação através de um procedimento de soma, de forma mental, mas durante a realização, deixou de somar com base quatro e passou a somar em base dez: "Quatro mais quatro, oito, mais quatro, dezesseis, mais quatro, trinta, mais quatro, quarenta, mais quatro, cinquenta, mais quatro, sessenta". G., portanto, compreendeu a que campo conceitual a situação-problema se filia - estruturas aditivas - mas apresentou equívoco no procedimento de resolução.

A pesquisadora sugeriu que G. utilizasse apoio no papel para a resolução da situação. G. produziu um algoritmo convencional de soma, ou seja, oito parcelas de quatro, mas a despeito disso, retomou sua forma inicial de resolução mental, confundindo-se ao longo do procedimento. A pesquisadora ofereceu as cédulas monetárias de dois reais para auxiliar na soma, porém tal estratégia não se mostrou útil, visto que, em vez de considerar o valor das cédulas, G. considerou sua quantidade. Diante disso, a pesquisadora sugeriu o 
uso de risquinhos, como procedimento de auxílio para a soma, sendo que, dessa forma $\mathrm{G}$. conseguiu resolver a situação-problema e chegar ao resultado de 32.

O desempenho de G. nessa situação-problema demonstra que seu raciocínio ainda necessita de suporte concreto para a resolução, mesmo de operações simples, como a de soma de unidades. $\mathrm{O}$ apoio em suporte concreto, nesse caso, os risquinhos, mostra-se o recurso que melhor auxilia G. na resolução correta dessas operações, apesar de consumir mais tempo, já que com a resolução mental, G. confunde-se na resolução e não realiza um julgamento da razoabilidade do resultado da operação.

A partir da obtenção de trinta e dois como resultado da compra de oito pedaços de bolo a quatro reais cada um, a pesquisadora simulou o pagamento da compra com trinta e cinco reais, solicitando que G. calculasse o troco. Para tanto, foi utilizado uma nota de vinte reais e três notas de cinco reais. G. novamente centrou-se na quantidade de cédulas quatro - em vez de seu valor.

A pesquisadora auxiliou G. a centrar-se no valor das cédulas, apresentando uma por uma enquanto G. as somava mentalmente e assim chegaram ao valor da soma das cédulas trinta e cinco reais. G. demonstrou não conhecer o conceito de troco e a pesquisadora explicou que troco trata-se da diferença entre o valor pago a mais pelo cliente em relação ao valor da compra.

Nesse contexto, a seguinte situação estava posta: G. deveria calcular o troco de trinta e cinco reais para um pagamento de trinta e dois reais. Sua primeira resolução parece ter sido proposta sem reflexão envolvendo operações matemáticas, configurando-se como uma resposta aleatória. A pesquisadora então introduziu o conceito de "a mais", o que parece ter favorecido o raciocínio de G., como pode ser observado na extração da transcrição abaixo: 


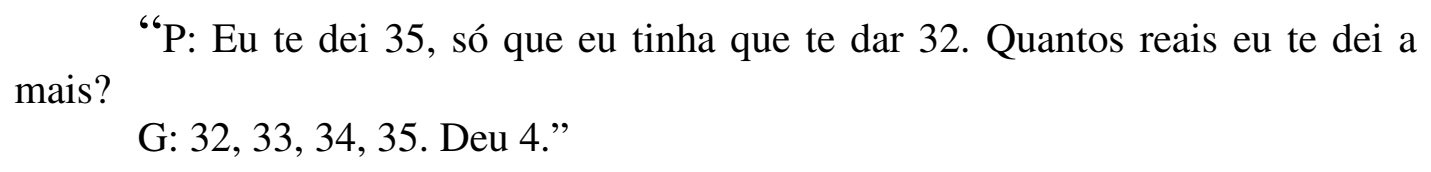

Pôde-se perceber que, ao introduzir o conceito de "a mais", a pesquisadora induziu G. a operar dentro da lógica matemática, o que é qualitativamente melhor do que a resposta aleatória oferecida em primeiro lugar. Percebeu-se também que G. considerou o 32 como pertencente ao conjunto de algarismos a serem contados na resolução dessa situação, o que revela alguma distorção conceitual do princípio da cardinalidade.

No momento de entregar o troco à pesquisadora, G. perseverou na consideração da quantidade de cédulas em detrimento do seu valor, porém, nessa situação, G. operou simultaneamente com os dois critérios, pois os quatro reais a serem devolvidos de troco foram elaborados com três notas de cinco reais e uma moeda de cinco reais. Ou seja, apesar de o critério principal ser a quantidade discreta de objetos - cédulas e moedas - a serem devolvidos como troco, G. teve o cuidado de garantir que todas as cédulas e moedas tivessem o mesmo valor.

Como última atividade dessa situação de intervenção, a pesquisadora sugeriu uma nova situação de compra, como a vivenciada anteriormente, mas com outros valores. Para tanto, ela sugeriu que G. realizasse o mesmo procedimento desenvolvido na situação anterior. Apesar de ter sido produzido há pouco tempo, G. autonomamente não se beneficiou do registro como roteiro para resolução da nova situação-problema. Dessa forma, sugere-se que em situações em que um registro for apresentado para auxiliar o desempenho de G., na resolução de uma situação-problema, que essa apresentação seja acompanhada de uma discussão anterior das etapas desenvolvidas e ali registradas. 


\subsubsection{Décima sexta sessão de intervenção psicopedagógica.}

Data: 08/06/2015 Duração: 44 minutos

Objetivos: Propor situações-problemas que envolvam o campo conceitual das estruturas distributivas e aditivas.

2.4.3.16.1 Desenvolvimento, resultados e discussão da décima sexta sessão de intervenção psicopedagógica.

Para o desenvolvimento dessa sessão de intervenção, foram utilizados vinte chocolates Chocolate e moedas reais de valor corrente. A pesquisadora propôs uma situação em que G. deveria descobrir o valor de cada chocolate a partir do valor da caixa inteira. G. verbalizou que não sabia como resolver essa situação, posicionando-se de uma forma diferenciada do que em sessões anteriores, nas quais ele pouco se posicionou de forma tão direta. Além disso, nessa sessão, G. introduziu assuntos alheios à sessão de intervenção, o que podia significar que a interação estabelecida com a pesquisadora tivesse diminuído seu caráter unilateral, em que geralmente ela introduzia os tópicos para discussão. Ao mesmo tempo, demonstrava que a pesquisadora tinha dado espaço para tal modificação acontecer.

A pesquisadora sinalizou explicitamente a troca para uma nova atividade, considerando as observações de sessões anteriores de que esse tipo de estratégia poderia beneficiar o desempenho de G. Ela propôs, então, uma situação referente ao campo conceitual das estruturas multiplicativas, em que um chocolate custava 10 centavos e G. deveria descobrir o valor de cinco chocolates.

G. elaborou quatro respostas para a resolução da situação apresentada. Na primeira, ele apenas contou a quantidade de chocolate. Na segunda, ofereceu uma resposta aleatória. $\mathrm{Na}$ terceira, remeteu-se a fatos numéricos, referentes à soma sucessiva em base 10. As 
mudanças nas respostas oferecidas surgiram como efeito da intervenção da pesquisadora que, após cada resposta dada, solicitava que G. demonstrasse, usando o chocolate e as moedas, como chegou à resposta dada.

A quarta resposta foi 50 e quando solicitado a explicar como a obteve, G. referiu “descobri pelo valor do 10". G. pode ter realizado uma soma ou multiplicação de forma mental, mas não soube expressar seu raciocínio verbalmente. A pesquisadora, então, solicitou que ele utilizasse as moedas para mostrar como procedeu. G. então contou cinco moedas de 10 centavos. G. conseguiu reproduzir o mesmo procedimento quando solicitado a calcular o valor total de oito chocolates, cada um custando 10 centavos.

O desempenho de G. nessas tarefas demonstrou habilidade na resolução de situações-problemas, que envolvem a soma em situações em que há o aumento da quantidade, com a incógnita no estado final. Observa-se também que ele se beneficiou do apoio em quantidades discretas, nesse caso as moedas, sendo que havia uma relação de um para um na quantidade de chocolate e de moedas.

O desempenho de G. modificou-se, porém, quando a relação entre o chocolate e as moedas foi de 1 para 2, ou seja, cada chocolate custava 20 centavos, G. reproduziu o procedimento de resolução como descrito acima, associando duas moedas de dez centavos para cada chocolate. No momento de contar o valor que custava o total de chocolates, G. considerou cada chocolate custando 10 centavos.

Duas hipóteses podem explicar seu desempenho. Uma delas é o fato de que, na atividade anterior, os chocolates custavam 10 centavos e G. perseverou na consideração dessa quantidade, mesmo depois da mudança para uma nova situação-problema, característica essa já observada anteriormente. A outra hipótese tem relação com a dificuldade de organização perceptual, em que G. contou apenas uma das duas linhas de 
moedas de dez centavos organizadas para representar o valor de cada chocolate. Essa característica também já foi observada anteriormente, especialmente na décima sessão de intervenção, na situação de contagem de pães de queijo e coxinhas.

Além disso, nessa situação ficou evidente que G. ainda não domina as regras referentes à formação do sistema monetário, relacionado aos números racionais, pois após realizar as somas sucessivas, com a ajuda da pesquisadora, de cada um dois seis chocolates a vinte centavos cada, G. realizou a seguinte contagem: 30, 40, 50, 60, 70, 80, 90, 100, 101, 102. Tal contagem mostra que, após o 100, G. deixou de contar em base dez e começou a contar unitariamente. Ele pode ter agido dessa forma por uma distorção conceitual da transformação dos 100 centavos em um real.

Essa hipótese é sustentada também pelas situações de interação posteriores, no contexto de uma terceira situação-problema em que havia quatro chocolates, cada um custando 25 centavos. Nessa situação, G. demonstrou muita dificuldade para obter vinte e cinco centavos a partir da soma de quantidades menores, usando as moedas.

Para a resolução da situação proposta, a do valor total da soma dos quatro chocolates, a pesquisadora sugeriu que G. realizasse um registro escrito como forma de auxiliar seu desempenho. Ele produziu um algoritmo convencional da adição, ou seja, quatro parcelas de vinte e cinco centavos e utilizou apoio em risquinhos para realizar a soma dos algarismos posicionados na casa das unidades. No momento da realização da soma das dezenas, G. verbalizou dúvida se deveria considerar o algarismo dois registrado acima dela, referente ao desagrupamento do 20 , resultado da soma das unidades, revelando preocupação quanto ao procedimento de desagrupamento.

Diante das observações dessa sessão de intervenção, pode-se dizer que G. compreendeu a natureza da situação-problema explorada, sendo que sua dificuldade residiu, 
mormente, na resolução da situação. O uso de material concreto novamente se mostrou benéfico para G., desde que com a consideração da possível dificuldade de organização espacial. Apesar da dúvida quanto ao procedimento do desagrupamento, G. é capaz de utilizar estratégias não algorítmicas de forma adequada a esse tipo de situação-problema.

\subsubsection{Décima sétima sessão de intervenção psicopedagógica.}

Data: 06/06/2015 Duração: 44 minutos

Objetivos: Avaliar o desenvolvimento de G., após as sessões de intervenção, com nova aplicação da Épreuve Conceptuelle de Résolution des Problèmes Numériques - ECPN (Groupe Cimete, 1995); retomar a situação-problema envolvendo o campo conceitual das estruturas distributivas, conforme a sessão anterior, com variação na quantidade envolvida, para verificar se essa mudança promove diferenças no desempenho do participante.

2.4.3.17.1 Desenvolvimento, resultados e discussão da décima sétima sessão de intervenção psicopedagógica.

Nessa sessão de intervenção, foram desenvolvidas duas atividades. A primeira referente à retomada da situação-problema de divisão, apresentada na décima sexta sessão de intervenção, a qual G. referiu não conseguir realizar e a segunda referente à nova aplicação da Épreuve Conceptuelle de Résolution des Problèmes Numériques - ECPN (Groupe Cimete, 1995).

Para o desenvolvimento da situação de divisão, foi utilizado o mesmo material: chocolates e moedas reais. Porém, a situação apresentada, nessa sessão, envolvia quantidades menores do que as quantidades envolvidas na sessão de intervenção anterior. Dessa forma, a pesquisadora apresentou três chocolates e disse que eles, juntos, custavam 
60 centavos, sendo que essa quantidade foi associada com seis moedas de 10 centavos. A questão da situação-problema era qual o valor de cada chocolate.

Diante dessa forma de apresentação da situação-problema, G. conseguiu desenvolver sua resolução sem nenhum tipo de dificuldade, mesmo quando, aos poucos a pesquisadora foi aumentando a quantidade de chocolates e seu valor. Em todas as situações vivenciadas, G. procedeu a uma distribuição das moedas que representavam o valor total dos chocolates, por cada chocolate. Esse dado significa que G. possui a capacidade de operar dentro do campo conceitual das estruturas distributivas, apesar da dificuldade de operar com quantidades maiores.

A segunda atividade consistiu da nova aplicação da Épreuve Conceptuelle de Résolution des Problèmes Numériques - ECPN (Groupe Cimete, 1995, Anexo 4), que está apresentada na Tabela 9. Para tanto, seguiu-se o mesmo roteiro descrito na sessão sobre avaliação psicopedagógica. Houve mudança, porém, no material utilizado, pois, na primeira aplicação, foram utilizados bonecos e cubos de madeira e na aplicação em questão foram utilizadas as figuras dos convidados da festa desenhados por G. na décima sessão de intervenção e chocolates. Considerando que os convidados para a festa são amigos e familiares de G. e são nomeados durante a aplicação da prova, para garantir que os princípios éticos sejam seguidos, os convidados foram identificados apenas com as letras iniciais de seu nome. 
Tabela 9

Descrição da prova ECPN, desempenho do participante e análise

\begin{tabular}{llll}
\hline \multicolumn{1}{c}{ Descrição da tarefa } & \multicolumn{1}{c}{ Ações do participante } & \multicolumn{1}{c}{ Análise } \\
\hline Item 1 - Descrever a & P: E aqui está o chocolate de cada um deles. O & G. realizou uma estimativa \\
situação & que você acha da divisão que eu fiz? & perceptual & sobre \\
(Comparação) & G: O que eu acho? & quantidades destinadas a cada \\
Situação inicial: 2 R, 3 & P: Isso. & um dos convidados. \\
LF, 7 LH. & G: Um com mais e outro com menos?
\end{tabular}

\section{Item 2 - Quem tem mais}

(Quem tem mais) Situação inicial: 2 R, 3 LF, 7 LH.
P: Isso. Quem é tem mais chocolate?

G: Meu pai.

P: Isso, o LH. Como é que você sabe que ele tem mais?

G: Porque minha mãe tem dois, meu irmão tem três e meu pai tem sete. 1,2. Espera aí. $1,2,3,4,5,6,7$.

\section{Item 3 - Todos} parecidos Situação inicial: 2 R, 3 LF, 7 LH.

P: Sabe o que eu queria que você fizesse agora? Arranjar um jeito de deixar todo mundo com a mesma quantidade de chocolate.

G: Beleza. Meu pai para cá. 1,2,3,4. 1,2,3,4,5.
1,2,3,4. Ah tá. É assim. Aqui. Pronto.

P: Muito bem.

G: Cada um com quatro. Esse aqui tem quatro, esse aqui tem quatro e esse aqui com quatro.

Situação final: 4 R, 4 LF, 4 LH.

Item 4 - "A mais que" a partir de estados iniciais diferentes (Quantificação da relação de ordem) a) Situação inicial: $3 \mathrm{R}$, $0 \mathrm{LF}, 7 \mathrm{LH}$.
P: Eu queria que você fizesse alguma coisa para que o LF fique com quatro a mais que a $\mathrm{R}$.

G: Quanto a mais?

P: 4. LF. com quatro a mais que a $R$.

G: $1,2,3,4,5$. Era quatro a mais?

P: Quatro a mais.

G: $1,2,3,4,5$.

P: Se você quiser usar esses aqui pode usar.

G: 4 a mais. 1,2,3,4,5. Pronto. Ah, tá, esse aqui é

4, aí esse aqui é 5, 6. 1,2,3,4,5,6.

P: Pronto?

G: Pronto.

P: Como é que você pode me mostrar que o LF. está com 4 a mais que a R.?

G: O meu irmão tem 6 e minha mãe tem 3 .

P: E o que significa que seu irmão tem 6 e sua mãe tem 3 ?

G: Que meu irmão tem 6 a mais e que minha mãe tem 3 a menos.

Situação final: 3 R, 6 LF, 2 LH.

P: Eu quero que você faça alguma coisa para o LF. ficar com 3 a mais que a $R$.
G. utiliza a contagem como forma de conferência de sua resposta.

G. desloca chocolates de LH para os demais convidados, igualando as quantidades de cada um.

G. desloca cinco chocolates de LH para LF.

G. pega mais chocolates da reserva e acrescenta para LF.

Quando solicitado a conferir o resultado, G. descreve a quantidade que cada convidado possui, mas não as 
b) Situação inicial: 4 R, 4 LF, 7 LH.
G: $1,2,3,4,5,6,7.1,2,3,4.1,2,3,4,5,6,7$.

P: O LF. está com 3 a mais que a R.?

G: Acho que está.

P: Como você sabe?

G: $1,2,3,4,5,6,7.4$ aqui. 3 aqui. Pronto.

$1,2,3,4,5,6.3$ a mais.

P: Me mostra, cadê esses 3 a mais?

G: 3 aqui e 3 aqui. Ah tá. Pronto.

P: Pronto? Não quer mexer mais nada?

G: Acho que não, acho que está bom.

Situação final: 4 R, 7 LF, 4 LH.

P: Eu quero que você faça alguma coisa para o

LH. ficar com 5 a mais do que a $R$.

G: Beleza. Cinco a mais?

P: Do que a R.

G: Aí esse aqui deixa assim, não é?

Situação inicial: 4 R, 6 LF, 6 LH. com 5 a mais do que a $R$.

\section{Item 6 - Pesquisa do estado inicial \\ (Pesquisa do estado inicial ou da transformação)}

Início com quatro blocos escondidos
P: Como você quiser fazer. O LH. tem que ficar

G: $1,2,3,4,5,6.7,8.1,2,3,4,5,6.1,2,3,4,5,6$.

$1,2,3,4,5,6,7,8,9,10,11$.

Pronto.1,2,3,4,5,6,7,8,9,10,11.

P: Pronto?

G: Pronto.

P: Como é que você sabe que o LH ficou com 5 a mais do que a R?

G: Porque meu pai tem 11 e minha mãe tem 4.

Situação final: 4 R, 1 LF, 11 LH.

P: Olha, eu escondi um tanto de chocolate na minha mão.

G: Beleza.

P: Agora a gente vai descobrir juntos quantos eu escondi. Já tem um tanto aqui e eu vou querer que você descubra quantos eu escondi. Agora, conta comigo quantos mais eu estou colocando.

Pe G (juntos): 1,2,3,4.

P: Agora eu tenho 7 na minha mão.

G: 7.

P: Quantas eu tinha no começo? Antes de colocar as 4 ?

G: Tinha 4. 11?

P: É? Olha aqui, essas são as 7 que eu tenho na minha mão. Eu tinha um tanto escondido e depois coloquei 4. Quanto que eu tinha no começo?

G: $1,2,3,4,5,6,7$.

P: Isso, tem 7, mas lembra que eu tinha um tanto escondido na minha mão primeiro?

G: $\mathrm{Sim}$.

P: Depois eu coloquei 4 junto com os escondidos. Quantos que eu tinha escondido?

G: Quantos você tinha no começo? Tinha 3.

P: Como que você sabe, me mostra.

G: Porque...Como é que eu sei?

P: É.

G: Ah, eu fiz de cabeça. compara e evidencia distorção conceitual na utilização dos conceitos de a mais e a menos, em relação à situação proposta.

G. retira um chocolate de LF e depois o retorna. Mesmo com a sugestão da pesquisadora, ele não estabelece conferência do resultado de suas ações.

G. desloca cinco chocolates de LF para LH, considerando apenas a quantidade presente no enunciado proposto pela pesquisadora, sem considerar a diferença preexistente na quantidade de chocolates dos convidados.
A primeira opção de resposta de G. tem relação com uma quantidade que esteve presente no item anterior. 
P: É. O que é que você fez de cabeça? Você fez uma conta?

G: Fiz.

P: Qual foi a conta que você fez?

G: Não sei. procedimento G. chega à resposta correta, mas não soube explicar o procedimento utilizado para obtê-lo.

\section{Item 7 - Transformação negativa (Pesquisa do estado inicial ou da transformação)}

P: Está bem, vou fazer outra coisa. Conta comigo quantos eu vou colocar aqui na minha mão agora. P e G (juntos): 1,2,3,4,5.

P: Vou tirar um tanto. Eu fiz alguma coisa e agora eu só tenho 3. O que eu fiz?

G: Tirou.

P: Tirei quantos?

G: 5 .

P: Tirei quantos?

G: 4 .

P: Vamos fazer de novo. Conta aqui quantos eu vou colocar na minha mão.

P e G (juntos): 1,2,3,4,5.

P: Eu vou tirar um tanto. Não olha. Olha com quantos eu fiquei.

G: 3 .

P: Quantos eu tirei?

G: 5 .
G. percebeu que a situação tratava-se de uma diminuição da quantidade, mas não operou através de uma transformação negativa.

Comparando o desempenho de G. na segunda aplicação da Épreuve Conceptuelle de Résolution des Problèmes Numériques - ECPN (Groupe Cimete, 1995) com a primeira aplicação dessa mesma prova, pode-se observar alguns aspectos interessantes. Na primeira realização da prova, no item 1 , G. não utilizou nenhum procedimento matemático para a resolução da situação. Já na segunda aplicação, ele engajou-se numa estimativa perceptual de quantidades. No item 2, observa-se a utilização do mesmo procedimento de contagem utilizado na primeira aplicação da prova, indicando a competência em comparar quantidades. No item 3, o que se pode observar é que G. demonstrou melhor desempenho na consideração todo/parte. 
O desempenho semelhante de G., nas duas aplicações, dos itens 4 e 5 denota que as situações que envolvem o conceito de "a mais que" ainda se constituem um desafio para ele. No item 6, pode-se notar a característica de G. de arbitrariamente utilizar as informações de uma dada situação, numa outra subsequente, como já apresentado e discutido em outras sessões de intervenção. Já no item 7, observa-se desenvolvimento de G. no sentido de identificar a transformação que sofreu a quantidade presente no enunciado, apesar de não ter conseguido operar no contexto de uma transformação negativa, ou seja, numa operação de subtração. A seguir, apresenta-se a discussão geral e as considerações finais desta pesquisa. 


\subsection{Discussão Geral}

Um dos aspectos discutidos no capítulo 2, deste trabalho, acerca da revisão de literatura sobre a inclusão escolar, referiu-se à escassez de estudos sobre o desenvolvimento psicológico e sobre a aprendizagem escolar da matemática, relacionados às diversas situações de inclusão escolar. Foi diante desse cenário que a pesquisa de intervenção foi assumida neste trabalho, visando produzir conhecimento sobre o desenvolvimento cognitivo e sobre a aprendizagem de matemática de um jovem com paralisia cerebral.

Assim, com a finalidade de se obter o conhecimento das particularidades do desenvolvimento psicológico de pessoas com diagnóstico de paralisia cerebral, foi assumida, como procedimento desta pesquisa de intervenção, a prática psicopedagógica. Conforme a proposta de Fávero (2002), já mencionada anteriormente, tal escolha foi motivada pela razão de que tal procedimento proporciona a ocasião para o desenvolvimento de novos esquemas cognitivos e, ao mesmo tempo, coloca em evidência o processo desse desenvolvimento.

Como visto na fundamentação teórica, a proposta de Fávero (2002) implica o desenvolvimento de três tarefas distintas e articuladas: a avaliação das competências matemáticas do sujeito e de suas dificuldades; a sistematização de cada uma das sessões de trabalho, em termos de objetivos e descrição das atividades propostas; e uma análise minuciosa do desenvolvimento das atividades para cada sessão. Tal análise deve ser realizada de modo a explicitar: a sequência de ações do sujeito; o significado destas ações em relação às suas aquisições de estruturas conceituais; o tipo de mediação estabelecida entre o adulto e o sujeito (Fávero, 2009).

Essa proposta também foi assumida em outros trabalhos como o de Fávero e 
Oliveira (2004) e o de Fávero e Pina Neves (2011). Trata-se, em outras palavras, de uma proposta que articula o consenso teórico-conceitual das grandes teorias do desenvolvimento psicológico e vincula a epistemologia do conhecimento e a epistemologia do ensinar e do aprender, através de quatro aspectos teóricos principais: 1. a evidência da interação entre as regulações cognitivas e as regulações sociais; 2 . o papel crucial da mediação semiótica no desenvolvimento psicológico humano; 3. a importância da relação entre representação, sistemas de signos e desenvolvimento psicológico; 4. a consideração da tomada de consciência como processo central do desenvolvimento psicológico (Fávero, 2009, 2011, 2014).

Desse modo, foi possível considerar as particularidades individuais do participante da pesquisa e, através da análise e da discussão dos dados, foi possível refletir sobre o significado dessas particularidades do ponto de vista do desenvolvimento de novas competências, de modo a ultrapassar o raciocínio circular de causalidade (Engelbrecht, 2013). São essas reflexões que serão apresentadas a seguir.

Como afirmado anteriormente e conforme descrito no item 2.2, que trata dos procedimentos de coleta de dados, durante as sessões de intervenção psicopedagógica a tomada de decisão sobre a condução das atividades, em termos de conceitos e instrumentos utilizados, foram definidas à medida que cada sessão se realizava e dava indícios para a próxima sessão. Quer dizer, foi o próprio desenvolvimento do participante, durante as atividades propostas, que fundamentou as sessões subsequentes.

Conforme descrição disponível no item 2.1, o participante foi diagnosticado com deficiência intelectual, associada ao diagnóstico de Paralisia Cerebral. Durante as sessões de intervenção, foi possível observar que G. apresenta dificuldades com funções mentais, como inclusão de classe, seriação, por exemplo, já esperadas para sua idade cronológica, 
mas, a despeito disso, pode-se observar também que G. demonstrou preocupações e interesses próprios da adolescência. Isso é compatível com o entendimento mais recente acerca da deficiência intelectual, de que dificuldades coexistem com potencialidades, ou seja, ficou evidente, no estudo, que é necessário se considerar sempre a relação entre competências e dificuldades e evitar o risco de se focar apenas nas dificuldades (Fávero (2003, 2009).

Nesse mesmo entendimento, os dados encontrados acerca das noções temporais apresentadas por G. são problematizados, visto que as dificuldades que apareceram nas sessões estiveram mais relacionadas à convenção do uso do calendário e do relógio. Possivelmente, uma das explicações para essas dificuldades pode estar relacionada com as oportunidades cotidianas de interação com esses instrumentos e sua lógica de funcionamento, como, por exemplo, a predominância do uso do relógio digital sobre o analógico. Essa possibilidade foi compartilhada com a mãe de G., ao longo das sessões de intervenção, sendo salientado formas pelas quais a família poderia contribuir para o desenvolvimento de G. nesse sentido.

Durante as sessões de procedimento psicopedagógico, os conceitos abordados foram apresentados predominantemente através de situações-problemas, de forma compatível com a defesa da fundamentação teórica desse trabalho, visto que o interesse da pesquisa esteve no desenvolvimento da atividade do sujeito e não numa resposta adequada ou não a uma situação dada (Fávero, 2014). A utilização de situações-problemas como instrumento de mediação de conhecimento, em uma determinada situação de interação social, como proposto por Fávero (2011) se mostrou uma abordagem adequada aos objetivos deste trabalho.

Através da análise das transcrições, pode-se perceber que, no início do estudo, G. 
utilizava frequentemente o recurso de repetir a fala da pesquisadora diante das situaçõesproblemas nas quais ele tinha dificuldade, como forma de auxiliar seu raciocínio nas situações em que não possuía os recursos necessários para sua resolução de forma autônoma. Para explicar o uso desse recurso, podem-se levantar duas hipóteses. A primeira delas é a possibilidade de que G. estivesse buscando uma forma de ganhar tempo para o desenvolvimento de seu raciocínio e a segunda seria a hipótese de que G. estaria buscando se esquivar da situação.

Com o desenvolvimento das sessões, pôde-se observar que a utilização desse recurso diminuiu de frequência e, inversamente, aumentou a quantidade de vezes em que G. falava consigo mesmo, possivelmente como forma de organizar seu raciocínio. Esse dado remete ao desenvolvimento da linguagem, conforme a teoria de Vygotsky (2009, conforme citado por Fávero 2014). Ou seja, as repetições e o falar para si mesmo expressam engajamento na resolução das situações-problemas apresentadas e foram utilizadas como instrumentos mediadores para a resolução de problemas (Vygostky, 2009, conforme citado por Fávero, 2014).

O que permite o desenvolvimento desse raciocínio é o fato de que, nas primeiras sessões, G. apenas reproduzia para si mesmo a fala da pesquisadora. Na sequência das sessões, ele falava consigo mesmo, verbalizando e avaliando possíveis estratégias de resolução da situação. Dessa forma, pode-se considerar esse dado como uma evidência do desenvolvimento psicológico de G., que ocorreu no decorrer das sessões psicopedagógicas.

Outro aspecto a ser salientado, é aquele referente à tendência de G. de generalizar o resultado de uma situação-problema para outra de mesma natureza, como, por exemplo, contagens ou adições. Essa generalização esteve muito presente na primeira sessão, o que pode significar que G. se via numa situação de avaliação próxima àquela da avaliação 
escolar. Por exemplo, numa situação de contagem em base $\mathrm{X}$, se a pesquisadora passava para uma contagem em base $\mathrm{Y}$, ele retomava o resultado da contagem em base $\mathrm{X}$, como se o mais importante fosse fornecer uma resposta.

No item 1.3, em que foi abordado o diagnóstico de paralisia cerebral e suas repercussões no desenvolvimento, uma dessas repercussões diz respeito a alterações na percepção, sendo que alguns autores começam a defender que tais alterações de percepção deveriam estar associadas à conceitualização da Paralisia Cerebral (Esben, 2003; Martins, Oliveira \& Amorim, 2008; Rosenbaum et al., 2005). No entanto, não se tem conhecimento dessa relação do ponto de vista do desenvolvimento psicológico.

No presente estudo, o que se aprendeu interagindo com G. foi a presença de uma dificuldade de organização perceptual, que se expressa em ocasiões particulares, principalmente em situações de contagem quando os elementos a serem contados não apresentavam uma organização espacial linear. Essa questão está referida e descrita nas discussões das sessões 1, 2, 3 e 10. A hipótese é de que essa dificuldade acompanha G. desde o início de sua vida escolar, não tendo sido adequadamente considerada na escolha da natureza dos instrumentos e na escolha da natureza das atividades propostas.

Um dos consensos entre as grandes teorias de desenvolvimento de Piaget, Wallon e Vygostky, conforme explica e argumenta Fávero (2014), é considerar o desenvolvimento humano como um processo de descentração, das percepções e aprendizagem elementares. Assim, reconhecer as questões perceptuais como possíveis fatores dificultadores na aprendizagem escolar, deve auxiliar na escolha da natureza do instrumento e da natureza das atividades propostas. O conhecimento de que no processo de desenvolvimento de pessoas com Paralisia cerebral as questões perceptuais podem ser um fator dificultador preponderante, torna-se extremamente importante para as práticas educacionais. 
Ainda utilizando o exemplo dos procedimentos de contagem realizados por G., em que se viu grande interferência da questão perceptual, e tomando a Teoria dos Campos Conceituais de Vergnaud (Fávero, 2014; Muniz, 2009) como base teórica para o entendimento da formação de conceitos, temos que o sentido de cada conceito é proveniente de um conjunto de situações, assim, podemos conjecturar que o fato de não ter sido levada em conta a questão perceptual, durante sua escolarização, gerou dificuldades com contagem e consequentemente com o conceito de número. Se, nesse processo, as práticas escolares permitirem que as questões perceptuais sobrepujem a dedução das propriedades pertinentes a um conjunto de situações, pode-se dizer que esse desenvolvimento conceitual pode sofrer distorções, com implicações em aprendizagem posteriores.

Retomando o exemplo da contagem, mencionado anteriormente, nas sessões de intervenção psicopedagógica, foram desenvolvidas situações em que todos os elementos a serem contados estavam dispostos numa fila, num círculo, ou dispostos de forma aleatória. Assim sendo, o desenvolvimento dos conceitos de contagem e de número envolveu a realização de contagens em todos esses tipos de situações e em outras mais.

Dessa forma, considera-se que um dos méritos desse trabalho foi oportunizar, ao participante, diversas situações de contagem, em diferentes contextos, de forma a contribuir para a ampliação dos esquemas cognitivos associados a esse procedimento. Considera-se também que tal forma de atuação pode se constituir uma alternativa de atuação profissional na mediação de conceitos em contextos de inclusão escolar.

Direcionando a discussão especificamente à resolução de operações matemáticas básicas, as sessões de intervenção evidenciaram que G. se beneficiou da contagem com quantidades discretas de elementos para realizar os cálculos. Se, como discutido 
anteriormente, a questão perceptual interfere no desempenho de G. a depender da apresentação do material a ser contado, então é possível que ele tenha tido dificuldade na construção de competências numéricas, ao longo de seu desenvolvimento, à medida que vivenciou diversas situações de uso de quantidades discretas, sem que esse material tenha sido previamente preparado para corresponder às necessidades perceptuais de G. Isto também pode ter sido frequente na vida escolar do participante da pesquisa e pode, inclusive, acontecer até o período atual. Dizendo com outras palavras, a escolha do material e a apresentação espacial são aspectos muito relevantes para auxiliar o desenvolvimento de competências matemáticas de estudantes que apresentem dificuldades perceptuais e com implicações para a prática de professores em sala de aula, sala de recursos e no atendimento psicopedagógico.

Considerando estas questões relativas à percepção, dois aspectos ficaram muito claros com o desenvolvimento desse estudo: o primeiro diz respeito à necessidade de limitação do espaço no qual os elementos para contagem são apresentados. O segundo refere-se, como já salientado antes, à necessidade de contagem dos elementos distribuídos de vários modos diferentes.

Sendo assim, vários aspectos sobre a percepção de G. foram esclarecidos. Por exemplo: a depender da disposição dos elementos a serem contados, havia a necessidade de se propor a utilização de pontos de referência. Foi o que ocorreu nas sessões décima primeira e décima segunda, quando, na contagem de elementos dispostos em forma circular, G. encontrou dificuldade para saber quais elementos já haviam sido contados. A proposta, durante esta atividade, foi a de utilizar uma marcação como ponto de referência. G entendeu a proposta e a acatou, com êxito.

Durante as sessões, G. demonstrou conhecer a representação convencional das 
operações matemáticas. No entanto, era desejável ampliar o seu entendimento dos significados que essas operações podem ter em diferentes contextos de situaçõesproblemas. No presente trabalho, apesar do desenvolvimento de um número considerável de sessões psicopedagógicas, foi possível focar as operações de adição e multiplicação, havendo menor oportunidade de situações-problemas envolvendo as operações de subtração e divisão.

A maioria das situações desenvolvidas, durante as sessões de intervenção, referiu-se ao conjunto dos números naturais, e foi a partir de atividade com transvasamento de líquido que G. evidenciou deduções sobre o conjunto dos números racionais, conforme apresentado nas discussões da décima segunda e décima quinta sessões. Sabe-se que o surgimento dos números racionais está ligado à necessidade de se medir grandezas variadas, como comprimento, massa e capacidade (Eves, 2002 conforme citado por Pina Neves, 2008). Dessa forma, sem surpresa, foi nesse mesmo contexto, o da medição de capacidade, que o conceito de números racionais apareceu no desenvolvimento das sessões de intervenção. Ainda segundo Pina Neves (2008), a construção de conceitos relacionados ao sistema decimal, em geral, e ao número racional, em particular, está relacionada à apropriação de conceitos já construídos e sua utilização em busca de soluções para novos problemas.

Pode-se dizer, sem dúvida, que tal processo foi observado no desenvolvimento de G., à medida que ele percebeu a insuficiência de seus esquemas referentes aos números naturais para realizar o registro do transvasamento de líquidos e adentrou em um novo campo conceitual, o dos números racionais. Fávero (2014), ao explicar acerca dos paradigmas de pesquisa que possibilitem colocar em evidência as dinâmicas e os processos no estudo do desenvolvimento cognitivo, também sinalizou a importância dos conflitos 
cognitivos ou da regulação, nas palavras de Piaget.

Na introdução da Parte II, deste estudo, foi citada a funcionalidade da representação gráfica dos conceitos mediados. A esse respeito, vale ressaltar que, a partir dos resultados deste estudo, essas representações devem ser produzidas e retomadas, considerando a dificuldade de organização perceptual que as pessoas com Paralisia Cerebral podem apresentar. Por esse motivo, mais uma vez, ressalta-se o procedimento psicopedagógico utilizado nesta pesquisa, em que a avaliação do desenvolvimento das sessões foi constante: a escolha dos materiais a serem utilizados nas sessões de intervenção e sua apresentação ocorreu a partir dos dados obtidos na sequência das sessões, seguida por novas avaliações.

Na sessão décima terceira, por exemplo, o objetivo era mediar quantos copos poderiam ser enchidos com uma garrafa de suco e, para tanto, foi utilizado água, porém, G. teve dificuldade em observar qual copo estava cheio e qual não estava cheio. Neste trabalho, foram priorizados o uso de materiais simples e disponíveis no cotidiano da maioria das pessoas. Esses materiais foram escolhidos de forma a permitir a manipulação por parte de G., portanto, considerando o papel ativo da atividade de representação no sentido de regular o pensamento (Vergnaud, 2009 conforme citado por Fávero, 2014) as representações produzidas nas sessões de intervenção, cumpriram seu papel de permitir a retomada de conceitos tratados nas sessões anteriores.

O sentido de número foi abordado na fundamentação teórica deste trabalho e nele foi focado o procedimento utilizado nas sessões de intervenção. $O$ julgamento da razoabilidade do resultado das operações matemáticas, por exemplo, foi abordado nas Sessõe 5. Confirme ilustra a Figura 6, nessa sessão G. resolveu uma operação de adição com desagrupamento das unidades, cometendo um equívoco nesse procedimento $(50+50$ 10). Todavia, ele priorizou o resultado da operação em detrimento do julgamento da 
razoabilidade do resultado. Esse resultado evidenciou um eco no desenvolvimento de G. da prática escolar de valorização das regras e procedimentos de resolução de operações matemáticas em detrimento do desenvolvimento de um senso numérico adequado.

A tomada de consciência é tida consensualmente como indício de desenvolvimento (Fávero, 2012, 2014) e em algumas situações pode-se considerar que G. demonstrou processos de tomada de consciência dos conceitos e relações abordadas, como na quinta sessão, em que G. relacionou o conceito de multiplicação com a soma de parcelas, ou na décima segunda sessão, na qual o participante observou que a disposição circular dos copos atrapalhava sua contagem. Retomando a proposta de intervenção psicopedagógica, como já mencionado anteriormente, a apresentação de situações-problemas tinha o objetivo de adotar a ideia de interlocução, ou seja,

uma situação de interação social de modo a evidenciar as regulações cognitivas dos sujeitos e sua tomada de consciência em função de um campo conceitual particular e a análise destes processos, a partir da produção e dos processos comunicacionais desenvolvidos nesta interação. (Fávero \& Souza, 2001, p.158).

Considera-se, dessa forma, que o procedimento de análise de dados, adotado neste trabalho, constituiu-se numa alternativa metodológica que atendeu à tendência internacional de oferecer oportunidade ao participante de expressar suas concepções, a despeito de suas dificuldades. Tal procedimento também pôde contribuir para a formação dos profissionais que atuam na escola ou em contexto clínico com G. e outros estudantes com Paralisia Cerebral e/ou com dificuldades de organização perceptual, além de fornecer dados e indicações relevantes para sobre os processos de inclusão escolar.

Do ponto de vista da pesquisadora, também houve desenvolvimento. O mais nítido deles pode ser observado ao longo das transcrições visto que, inicialmente, ela não oferecia 
espaços de interlocução para G. e, ao longo do tempo, foi percebendo a necessidade de ampliação desse espaço, o que contribuiu para a maior expressão e participação de G. durante as sessões de intervenção psicopedagógicas. No início, as interações propostas pela pesquisadora se caracterizavam prioritariamente por incitar o participante a fazer algo e, em seguida, justificar-se. Com o transcorrer das sessões de intervenção e as reflexões propiciadas pelo processo de análise das transcrições, se observa o surgimento de interações que se caracterizavam mais na esfera da informação, com explicações e exemplificações.

Uma das conclusões da terceira categoria de artigos apresentados na revisão bibliográfica relaciona a prática profissional facilitadora da inclusão e a formação profissional. Considera-se, portanto, que este trabalho contribui nesse sentido, à medida que revela o desenvolvimento da pesquisadora e pode servir como inspiração para outros profissionais que se interessem pelo tema. 


\subsection{Considerações Finais}

Nessas considerações finais, será retomada a fundamentação teórica do estudo e será estabelecida relações com os dados que obtidos, tanto do ponto de vista teórico e conceitual como metodológico. Em primeiro lugar, serão retomadas as principais conclusões que permearam todas as categorias de análise da revisão bibliográfica: a relevância da consideração da subjetividade dos estudantes beneficiários da inclusão escolar, a aparente dicotomia entre as políticas públicas e a sua efetivação prática, e a formação profissional, com ênfase particular no professor.

Conforme discutido na primeira categoria de publicações, aquelas que tratam sobre aspectos teóricos da inclusão escolar, a consideração da subjetividade dos estudantes precisa ser garantida e tem relação com seu tempo de permanência na escola. Pode-se dizer que considerar as especificidades do desenvolvimento cognitivo dos estudantes com Paralisia Cerebral é uma forma de levar em conta sua subjetividade no processo de inclusão escolar, já que isso significa caminhos próprios ou isotrópicos de desenvolvimento (Braga, 1995). A revisão da literatura, item 1.1 desse trabalho, apontou a necessidade de pesquisas sobre formas de desenvolvimento atípico e, no sentido discutido anteriormente, acredita-se que este trabalho atendeu a essa necessidade.

Ao mesmo tempo e de forma relacionada, considera-se que os resultados deste trabalho ressaltam a importância do ambiente escolar, principalmente do ponto de vista do desenvolvimento psicológico dos estudantes. Desse modo, ele responde a uma necessidade apontada pela literatura nesse sentido.

A avaliação e a intervenção psicopedagógica mostram-se métodos apropriados para tratar a casuística aqui apresentada e pode se constituir num instrumento útil nas salas de recursos, de atendimento educacional especializado, espaços previstos na legislação da 
inclusão escolar (Brasil, 2007), além de serem adequadas para a prática psicopedagógica clínica. Duas considerações a esse respeito devem ser salientadas. A primeira diz respeito à utilização de situações-problemas como instrumento de mediação do conhecimento e a segunda diz respeito à relação dialética entre a aquisição conceitual e a capacidade de resolução de problemas. Ambas as considerações se relacionam com o desenvolvimento das competências dos alunos e com o desenvolvimento das competências do adulto (Fávero, 2011).

Especialmente do ponto de vista do professor, o possível benefício, advindo deste trabalho, envolve a tomada de consciência dos significados que sustentam sua prática, as implicações que dela decorrem e a tomada de consciência da existência de outros modos de refletir sobre ela (Fávero, 2011). Assim, a abordagem metodológica aqui apresentada pode se constituir um instrumento útil na prática profissional.

Ahmmed (2013) observa que o nível de suporte que os professores sentem que recebem pode influenciar suas atitudes para a inclusão. Dessa forma, consideramos que este trabalho auxilia na formação profissional na área de educação inclusiva, além de responder também à preocupação do autor romeno Ghergut (2011), quando pondera sobre a necessidade de que haja maior divulgação e sistematização de propostas que sustentem o paradigma da inclusão escolar. Também consideramos que a metodologia adotada neste trabalho responde à preocupação internacional (Kurth, 2009; Engelbrecht, 2013) de efetivação dos pressupostos inclusivos, à medida que aponta caminhos e possibilidades para o seu desenvolvimento.

Conclui-se também que a transição para a vida adulta é um dos aspectos que poderiam ser abordados no espaço de pesquisa existente na literatura a respeito da transição para a vida adulta de pessoas com Paralisia Cerebral. Outra possibilidade seria 
acompanhar a proposta de Rankin (2008) de se levar em consideração o contexto de desenvolvimento dos participantes com Paralisia Cerebral, visto que, os marcadores de transição para a vida adulta podem ser diferentes ou compreendidos de formas diferentes para essas pessoas, com impacto em seu desenvolvimento.

A dificuldade apresentada por G. em utilizar o calendário pode ser entendida como uma situação ilustrativa dessa questão, no sentido de que ele pode ter sido poupado dessa vivência ao longo do tempo, comprometendo seu conhecimento sobre a lógica de funcionamento desse recurso de registro do tempo, pois, como foi abordado no item 1.4, a superproteção pode ser uma variável que dificulta o desenvolvimento psicossocial. Por fim, consideramos também que este trabalho respondeu à necessidade de estudos longitudinais e de intervenção, particularmente em relação às competências matemáticas, centrados no desenvolvimento psicológico de estudantes incluídos em escolas regulares, a partir de uma proposta que permita a evidenciação de seu desenvolvimento, conforme apontado por Chiesa e Fávero (2014). 


\section{Referências}

Angelides (2011). Forms of Leadership that Promote Inclusive Education in Cypriot Schools. Educational Management Administration \& Leadership, 40(1), 21-36.

Ahmmed (2013). Measuring perceived school support for inclusive education in Bangladesh: the development of a context-specific scale. Asia Pacific Educ. Rev., 14, $337-344$.

Alexandersson. U. (2011). Inclusion in practice: Sofia's situations for interaction. International Journal of Special Education, 26(3). 114-123.

Almeida, C. A., Marisa, C. M., Melo, A. P. P., \& Drommond, A. de F. (2011). Barreiras e facilitadores no processo de inclusão de crianças com paralisia cerebral em escolas de ensino regular. Cadernos de Terapia Ocupacional da UFSCar, 19(2), 203-213.

Anache, A. A., \& Mitjáns, A. M. (2007). Deficiência mental e produção científica na base de dados da CAPES: o lugar da aprendizagem. Psicologia Escolar e Educacional, 11(2), 253-274. Acessado em 05 de maio de 2014, em:

http://www.scielo.br/scielo.php?script=sci_arttext\&pid=S1413$85572007000200006 \& \operatorname{lng}=$ pt\&tlng=pt. 10.1590/S1413-85572007000200006.

Arantes, F. F. (2010). De quem - ou do quê - depende o sucesso da inclusão escolar? Estilos da Clinica, 15(1), 96-115. Acessado em 06 de abril de 2014, em: http://pepsic.bvsalud.org/scielo.php?script=sci_arttext\&pid=S1415$71282010000100007 \& \operatorname{lng}=$ pt\&tlng=pt.

Araújo, M. V. de, Rusche, R. J., Molina, R., \& Carreiro, L. R.R. (2010). Formação de professores e inclusão escolar de pessoas com deficiência: análise de resumos de artigos na base SciELO. Revista Psicopedagogia, 27(84), 405-416. Acessado em 06 de 
abril de 2014, em: http://pepsic.bvsalud.org/scielo.php?script=sci_arttext\&pid=S0103$84862010000300010 \& \operatorname{lng}=$ pt\&tlng=pt. .

Areosa, A. L. (2007). Transpondo barreiras: o percurso dos portadores de necessidades especiais ao longo dos tempos. Psicologia em Pesquisa, 1(1), 08-14. Acessado em 06 de abril de 2014, em:

http://pepsic.bvsalud.org/scielo.php?script=sci_arttext\&pid=S1982-

$12472007000100003 \& \operatorname{lng}=$ pt\&tlng=pt.

Arnett, J. J. (2001). Conceptions of the Transition to Adulthood: Perspectives From Adolescence Through Midlife. Journal of Adult Development, 8(2) 133-143.

Artioli, A. L. (2006). A educação do aluno com deficiência na classe comum: a visão do professor. Psicologia da Educação, 23, 103-121. Acessado em 06 de abril de 2014, em: http://pepsic.bvsalud.org/scielo.php?script=sci_arttext\&pid=S1414$69752006000200006 \& \operatorname{lng}=$ pt\&tlng=pt. .

Ávila, C. F. de, Tachibana, M., \& Vaisberg, T. M. J. A. (2008). Qual é o lugar do aluno com deficiência? O imaginário coletivo de professores sobre a inclusão escolar. Paidéia, 18(39), 155-164. Acessado em 02 de maio de 2015, em:

http://www.scielo.br/scielo.php?script=sci_arttext\&pid=S0103863X2008000100014\&lng=pt\&tlng=pt. 10.1590/S0103-863X2008000100014

Barbosa (2007). Sentido de número na infância: uma interconexão dinâmica entre conceitos e procedimentos. Paidéia, 17(37), 181-194.

Barbosa, A. J. G., \& Conti, C. F. (2011). Formação em psicologia e educação inclusiva: um estudo transversal. Psicologia Escolar e Educacional, 15(2), 231-234. Acessado em 05 de maio de 2014, em: 
http://www.scielo.br/scielo.php?script=sci_arttext\&pid=S1413-

$85572011000200005 \& \operatorname{lng}=$ pt\&tlng=pt. $10.1590 /$ S1413-85572011000200005.

Barbosa, E. T., \& Souza, V. L. T. (2009). A vivência de professores sobre o processo de inclusão: um estudo da perspectiva da Psicologia Histórico-Cultural. Revista Psicopedagogia, 27(84), 352-362. Acessado em 06 de abril de 2014, em: http://pepsic.bvsalud.org/scielo.php?script=sci_arttext\&pid=S0103$84862010000300005 \& \operatorname{lng}=$ pt\&tlng=pt.

Barone, L. M. C. (2013). Reflexões sobre inclusão: desamparo e compromisso ético. Revista Psicopedagogia, 30(93), 2012-2017. Acessado em 06 de abril de 2014, em: http://pepsic.bvsalud.org/scielo.php?script=sci_arttext\&pid=S0103$84862013000300007 \& \operatorname{lng}=$ pt\&tlng=pt.

Bastos, M. B., \& Kupfer, M. C. M. (2010). A escuta de professores no trabalho de inclusão escolar de crianças psicóticas e autistas. Estilos da Clínica, 15(1), 116-125. Acessado em 06 de abril de 2014, em:

http://pepsic.bvsalud.org/scielo.php?script=sci_arttext\&pid=S1415$71282010000100008 \& \operatorname{lng}=$ pt\&tlng=pt.

Batista, M.W., \& Enumo, S. R. F. (2004). Inclusão escolar e deficiência mental: análise da interação social entre companheiros. Estudos de Psicologia (Natal), 9(1), 101-111. Acessado em 05 de maio de 2014, em: http://www.scielo.br/scielo.php?script=sci_arttext\&pid=S1413294X2004000100012\&lng=pt\&tlng=pt. 10.1590/S1413-294X2004000100012.

Beetham, G., \& Demetriades, J. (2007). Feminist research methodologies and development: overview and practical application. Gender \& Development, 15( 2), 199-216. 
Begeny, J. C., \& Martens, B. K. (2007). Inclusionary Education in Italy. Remedial and special education.28(2) March/April, 80-94.

Benedetti, I., \& Urt, S. C. (2008). Escola, ética e cultura contemporânea: reflexões sobre a constituição do sujeito que "não aprende". Psicologia da Educação, 27, 141-155. Acessado em 06 de abril de 2014, em:

http://pepsic.bvsalud.org/scielo.php?script=sci_arttext\&pid=S1414$69752008000200008 \& \operatorname{lng}=$ pt\&tlng=pt. .

Benevides, P. S. (2011). As retóricas contemporâneas e a significação da educação inclusiva. Psicologia \& Sociedade, 23(2), 248-253. Acessado em 05 de maio de 2014, em: http://www.scielo.br/scielo.php?script=sci_arttext\&pid=S0102$71822011000200005 \& \operatorname{lng}=$ pt\&tlng=pt. 10.1590/S0102-71822011000200005.

Bines, H., \& Lei, P. (2011). Disability and education: The longest road to inclusion. International Journal of Educational Development, 31, 419-424.

Bernardino, L. M. F. (2007). A contribuição da psicanálise para a atuação no campo da educação especial. Estilos da Clinica, 12(22), 48-67. Acessado em 06 de abril de 2014, em: http://pepsic.bvsalud.org/scielo.php?script=sci_arttext\&pid=S1415$71282007000100004 \& \operatorname{lng}=\mathrm{pt} \& \operatorname{tlng}=\mathrm{pt}$.

Bjorgaas, H. M., Hysing, M., \& Elgen, I. (2012). Psychiatric disorders among children with cerebral palsy at school starting age. Research in Developmental Disabilities, 33, 1287-1293.

Bottcher. L. (2010). Children with spastic cerebral palsy, their cognitive functioning, and social participation: a review. Child Neuropsychology, 16, 209-228.

Braga, L. W. (1995). Cognição e paralisia cerebral. Salvador: Sarah Letras.

Brandt, C. F., Camargo, J. A., \& Rosso, A. J. (2004). Sistema de Numeração Decimal: 
operatividade discente e implicações para o trabalho docente. Zetetiké, 12(22), 89-124. Brasil (1996). Ministério da Educação. Lei de Diretrizes e Bases da Educação Nacional. Acessado em 06 de abril de 2014, em: portal.mec.gov.br/seb/arquivos/pdf/livro03.pdf. Brasil.(1997). Ministério da Educação /SEF. Parâmetros curriculares nacionais: matemática. Acessado em 06 de abril de 2014, em: portal.mec.gov.br/seb/arquivos/pdf/livro03.pdf

Brasil. (2007). Ministério da Educação /SEESP. Política Nacional de Educação Especial na Perspectiva da Educação Inclusiva. Acessado em 06 de abril de 2014, em: peei.mec.gov.br/arquivos/politica_nacional_educacao_especial.pdf.

Brasil. (2008). PDE: Plano de Desenvolvimento da Educação: SAEB: ensino médio: matrizes de referência, tópicos e descritores. Brasília: MEC, SEB; Inep, 127 p.

Brasil. (2014). Movimento Todos pela Educação. Acessado em 06 de abril de 2014, em: http://www.todospelaeducacao.org.br/reportagens-tpe/31084/inclusao-de-alunos-comdeficiencia-cai-no-ensino-medio/

Cintra, G. M. S., Rodrigues, S. D., \& Ciasca, S. M. (2009). Inclusão escolar: há coesão nas expectativas de pais e professores? Revista Psicopedagogia, 26(79), 55-64. Acessado em 06 de abril de 2014, em:

http://pepsic.bvsalud.org/scielo.php?script=sci_arttext\&pid=S0103$84862009000100008 \& \operatorname{lng}=$ pt\&tlng $=$ pt. .

Camargo, S. P. H., \& Bosa, C. A. (2009). Competência social, inclusão escolar e autismo: revisão crítica da literatura. Psicologia \& Sociedade, 21(1), 65-74. Acessado em 05 de maio de 2014, em: http://www.scielo.br/scielo.php?script=sci_arttext\&pid=S0102$71822009000100008 \& \operatorname{lng}=$ pt\&tlng=pt. 10.1590/S0102-71822009000100008.

Cazeiro, A. P. M., \& Lomônaco, J. F. Bi. (2011). Formação de conceitos por crianças com 
paralisia cerebral: um estudo exploratório sobre a influência de atividades lúdicas. Psicologia: Reflexão e Crítica, 24(1), 40-50. Acessado em 05 de maio de 2014, em: http://www.scielo.br/scielo.php?script=sci_arttext\&pid=S0102$79722011000100006 \& \operatorname{lng}=$ pt\&tlng=pt. 10.1590/S0102-79722011000100006.

Chaabra,S., Srivastava, R., \& Srivastava, I. (2010). Inclusive education in Botswana: The perceptions of school teachers. Journal of Disability Policy Studies, 20(4) 219-228.

Chiesa, A. A. P., \& Fávero. M. H. (2014, Junho). A inclusão escolar nos periódicos brasileiros: um estudo de análise e síntese sobre concepções e práticas. Trabalho apresentado no VI Colóquio de Psicologia Escolar, Brasília - DF.

Crochík, J. L., Freller, C. C., Dias, M. A. de L., Feffermann, M., Nascimento, R. B. do, \& Casco, R. (2009). Atitudes de professores em relação à educação inclusiva. Psicologia: ciência e profissão, 29(1), 40-59. Acessado em 06 de maio de 2014, em: http://pepsic.bvsalud.org/scielo.php?script=sci_arttext\&pid=S1414$98932009000100005 \& \operatorname{lng}=p t \& t \operatorname{lng}=p t$.

Crochík, J. L., Freller, C. C., Dias, M. A. de L., Feffermann, M., Nascimento, R. B. do, \& Casco, R. (2013). Educação inclusiva: escolha e rejeição entre alunos. Psicologia \& Sociedade, 25(1), 174-184. Acessado em 06 de maio de 2014, em: http://www.scielo.br/scielo.php?script=sci_arttext\&pid=S0102$71822013000100019 \& \operatorname{lng}=$ pt\&tlng=pt. 10.1590/S0102-71822013000100019.

Cruz, M. B. (2011). Bonecas, diversidade e inclusão: brincando com as diferenças. Revista Psicopedagogia, 28(85), 41-52. Acessado em 06 de abril de 2014, em: http://pepsic.bvsalud.org/scielo.php?script=sci_arttext\&pid=S0103$84862011000100005 \& \operatorname{lng}=$ pt\&tlng=pt.

Dazzani, M. V. M. (2010). A psicologia escolar e a educação inclusiva: Uma leitura crítica. 
Psicologia: Ciência e Profissão, 30(2), 362-375. Acessado em 05 de maio de 2014, em: http://www.scielo.br/scielo.php?script=sci_arttext\&pid=S141498932010000200011\&lng=pt\&tlng=pt. 10.1590/S1414-98932010000200011.

Declaração de Salamanca (1994). Conferência mundial sobre necessidades educativas especiais: acesso e qualidade. Salamanca, Espanha, 7-10 de Junho de 1994.

Dellatolas, G., Filho, G. N., Souza, L., Nunes. L. G., \& Braga, L. W. (2005). Manual skill, hand skill asymmetry, amd neuropsychological test performance in schoolchildren with spastic cerebral palsy. Laterality, 10(2), 161-182.

Distrito Federal. (2014). Censo Escolar. [Arquivo de dados]. Brasília, DF. Acesso em 06 de abril de 2014, em: http://www.se.df.gov.br/educacao-df/rede-part-conv.html

Eidt, N. M., \& Tuleski, S. C. (2010). Transtorno de déficit de atenção/hiperatividade e psicologia histórico-cultural. Cadernos de Pesquisa, 40(139), 121-146. Acessado em 12 de abril de 2014, em:

http://www.scielo.br/scielo.php?script=sci_arttext\&pid=S0100$15742010000100007 \& \operatorname{lng}=$ pt\&tlng=pt. 10.1590/S0100-15742010000100007.

Engelbrecht, P. (2013). Teacher education for inclusion, international perspectives. European Journal of Special Needs Education. 28(2), 115-118.

Esben, P. (2003). New CP - Cerebral Palsy: hold the light. Copenhagen: The Danish Society for Cerebral Palsy.

Escobal, G., Rossit, R. A. S., \& Goyos, C. (2010). Aquisição de conceito de número por pessoas com deficiência intelectual. Psicologia em Estudo, 15(3), 467-475. Acessado em 05 de maio de 2014, em:

http://www.scielo.br/scielo.php?script=sci_arttext\&pid=S1413-

$73722010000300004 \& \operatorname{lng}=$ pt\&tlng=pt. 10.1590/S1413-73722010000300004. 
Espote, R., Serralha, C. A., \& Scorsolini-Comin, F. (2013). Inclusão de surdos: revisão integrativa da literatura científica. Psico-USF, 18(1), 77-88. Acessado em 05 de maio de 2014, em: http://www.scielo.br/scielo.php?script=sci_arttext\&pid=S1413$82712013000100009 \& \operatorname{lng}=$ pt\&tlng=pt. 10.1590/S1413-82712013000100009.

Fabrício, N. M. C., \& Cantos, P. V. V. (2011). Diagnóstico- intervenção- perspectivas: atuação da escola inclusiva. Construção psicopedagógica, 19(19), 112-121. Acessado em 06 de abril de 2014, em:

http://pepsic.bvsalud.org/scielo.php?script=sci_arttext\&pid=S141569542011000200009\&lng=pt\&tlng=pt.

Facci, M. G. D. (2010). A escola é para poucos?: A positividade da escola no desenvolvimento psicológico dos alunos em uma visão Vygotskyana. Revista Psicologia Política, 10(20), 315-328. Acessado em 06 de abril de 2014, em: http://pepsic.bvsalud.org/scielo.php?script=sci_arttext\&pid=S1519549X2010000200010\&lng=pt\&tlng=pt.

Fávero, M. H. (1994). O valor sócio-cultural dos objetos e a natureza sócio-cultural das ações humanas: a mediação exercida pelo meio escolar no desenvolvimento e na construção do conhecimento. Anais do Congresso Nacional de Psicologia Escolar, 2, Campinas, pp. 58-61.

Fávero, M. H. (2001). "E se fosse comigo?”: Os adolescentes frente a uma situação hipotética de gravidez. Universitas - Psicologia, 2, 62-81. Acessado em 13 de novembro de 2014, em: http://mhelenafavero.com.br/artigoscientificos.html FÁVERO, M.H. (2002) A aquisição da matemática e a intervenção psicopedagógica. Simpósio: deficientes uma articulação entre a teoria e a prática. Em: I Congresso Brasileiro, Psicologia: Ciência e Profissão. Setembro, US, São Paulo,. 
Fávero, M. H. (2005). Desenvolvimento psicológico, mediação semiótica e representações sociais: por uma articulação teórica e metodológica. Psicologia: Teoria e Pesquisa, $21(1), 17-25$.

Fávero, M. H. (2010). Psicologia do gênero: Psicobiografia, Sociocultura e Transformações. Curitiba: Editora UFPR.

Fávero, M. H. (2011). A pesquisa de intervenção na psicologia da Educação Matemática: aspectos conceituais e metodológicos. Educar em Revista, 1, 47-62.

Fávero, M. H. (2014). Psicologia \& Conhecimento. Subsídios da psicologia do desenvolvimento para a análise do ensinar e aprender. Brasília: Editora UnB.

Fávero, M. H., \& Carneiro Soares, M. T. (2002). Iniciação escolar e a notação numérica: uma questão para o estudo do desenvolvimento adulto. Psicologia: Teoria e Pesquisa, $18(1), 43-50$.

Abrão, L. G. M. ; Fávero, M. H. (2006). Salas virtuais de bate-papo sexual: a velha novidade da divisão de papéis de gênero. In: Seminário Internacional fazendo o Gênero 7. Gênero e Preconceitos, 2006, Florianópolis, SC. Cristina S. Wolff, Marlene de Faveri e Tânia Regina O. Ramos (Orgs.), 2006, Florianópolis. Anais do Seminário Internacional Fazendo o Gênero 7 . Gênero e Preconceitos. Florianópolis : Editora Mulheres, v. 1.

Fávero, M. H., Cunha, C. (2009) (Orgs). Psicologia do Conhecimento: O diálogo entre as ciências e a cidadania. Brasília: Unesco, Instituto de Psicologia da Universidade de Brasília, Liber Livro Editora, 332 p.

Fávero, M. H., \& Gomes de Sousa, C. M. S.(2001). A resolução de problemas em Física: 
revisão de pesquisa, análise e proposta metodológica. Investigações em Ensino de Ciências, 6(2), p. 143-196.

Fávero, M. H., \& Oliveira, D. (2004). A construção da lógica do sistema numérico por uma criança com Síndrome de Down. Educar, Dossiê Educação Especial. Curitiba: Editora UFPR, 23, 65-85.

Fávero, M. H., \& Pimenta, M. L. (2006). Pensamento e linguagem: a língua de sinais na resolução de problemas. Psicologia: Reflexão e Crítica, Porto Alegre, 19(2), pp. 225236.

Fávero, M. H., \& Pina Neves, R. S. (2009). Competências para resolver problemas e para analisar a resolução de problemas. Revista Semestral da Associação Brasileira de Psicologia Escolar e Educacional (ABRAPEE), 13(1), 113-124.

Fávero, M. H., \& Pina Neves, R. S. (2011). La intervención psicopedagógica como opción teórico-metodológica para la formación inicial de professores de matemática. UNIÓN, Revista Iberoamericana de Educación Matemática, 28, 99-116, Diciembre.

Fávero, M. H., \& Salim, C. M. R. (2001). Avaliação cognitiva na paralisia cerebral: utilização da análise qualitativa do WISC. Universitas. Psiciologia (UNICEUB), Brasília, DF, 2(2), 07-37.

Ferreira, J. M., Souza, C. S. de, Silva, R. M. R., \& Dechichi, C. (2009). Arte, Formação de Professores e Inclusão Escolar: Possibilidades de atuação do psicólogo em contextos educacionais. Cadernos de Psicopedagogia, 7(13), 25-41. Acessado em 06 de abril de 2014, em: http://pepsic.bvsalud.org/scielo.php?script=sci_arttext\&pid=S1676$10492009000100002 \& \operatorname{lng}=$ pt\&tlng=pt.

Freitas, M. C., \& Mendes, E. G. (2008). Análise funcional de comportamentos inadequados e inclusão: uma contribuição à formação de educadores. Temas em Psicologia, 16(2), 
261-271. Acessado em 06 de abril de 2014, em:

http://pepsic.bvsalud.org/scielo.php?script=sci_arttext\&pid=S1413389X2008000200009\&lng=pt\&tlng=pt. .

Freitas, P. M. (2009). Perfil neuropsicológico das paralisias cerebrais: hemiplégica e diplégica. (Tese de doutorado). Acessado em 06 de abril de 2014, em: http://www.bibliotecadigital.ufmg.br/dspace/handle/1843/BUOS-8NPHDE.

Freller, C. C. (2010). É possível ensinar educadores a incluir?: Como ensinar educadores a ensinar alunos de inclusão? Estilos da Clinica, 15(2), 326-345. Acessado em 06 de abril de 2014, em: http://pepsic.bvsalud.org/scielo.php?script=sci_arttext\&pid=S1415$71282010000200004 \& \operatorname{lng}=$ pt\&tlng=pt. .

Galambos, N. L., Magill-Evans, J., \& Darrah, J. (2008). Psychosocial maturity in the transition to adulthood for people with and without motor disabilities. Rehabilitation Psychology, 53(4), 498-504.

Garrido, J., \& Moysés, M. A. A. (2011). Um panorama nacional dos estudos sobre a medicalização da aprendizagem de crianças em idade escolar. In: Conselho Regional de Psicologia de São Paulo; Grupo Interinstitucional Queixa Escolar (Eds.), Medicalização de crianças e adolescentes: conflitos silenciados pela redução de questões sociais a doenças de indivíduos. (pp. 149-161). São Paulo: Casa do Psicólogo.

Gesser, M., Nuernberg, A. H., \& Toneli, M. J. F. (2012). A contribuição do modelo social da deficiência à psicologia social. Psicologia \& Sociedade, 24(3), 557-566. Acessado em 05 de maio de 2014, em:

http://www.scielo.br/scielo.php?script=sci_arttext\&pid=S0102-

$71822012000300009 \& \operatorname{lng}=$ pt\&tlng=pt. 10.1590/S0102-71822012000300009. 
Gil, R. (2002). Neuropsicologia. $2^{\mathrm{a}}$ ed. São Paulo: Editora Santos.

Ghergut, A. (2011). Education of children with special needs in romania: attitudes and experiences. Procedia Social and Behavioral Sciences, 12, 426-435.

Gomes, C. (2006). Estilos de aprendizagem e inclusão escolar: uma proposta de qualificação educacional. Revista Psicopedagogia, 23(71), 134-144. Acessado em 06 de abril de 2014, em:

http://pepsic.bvsalud.org/scielo.php?script=sci_arttext\&pid=S0103$84862006000200007 \& \operatorname{lng}=$ pt\&tlng=pt.

Gomes, C., \& Rey, L. G. (2007) Inclusão Escolar: Representações Compartilhadas de Profissionais da Educação acerca da Inclusão Escolar. Psicologia ciência e profissão. 27(3), 406-417.

Gomes, C., \& Souza, V. L. T. (2009a). Fracassos, representações e exclusões no processo de permanência na escola. Revista Psicopedagogia, 26(79), 41-47. Acessado em 06 de abril de 2014, em: http://pepsic.bvsalud.org/scielo.php?script=sci_arttext\&pid=S0103$84862009000100006 \& \operatorname{lng}=$ pt\&tlng=pt.

Gomes, C., \& Souza, V. L. T. (2009b). Instituições privadas de ensino: considerações para o processo de inclusão. Revista Psicopedagogia, 26(81), 415-424. Acessado em 06 de abril de 2014, em: http://pepsic.bvsalud.org/scielo.php?script=sci_arttext\&pid=S0103$84862009000300009 \& \operatorname{lng}=$ pt\&tlng=pt. .

Gomes, C., \& Souza, V. L. T. (2011). Educação, psicologia escolar e inclusão: aproximações necessárias. Revista Psicopedagogia, 28(86), 185-193. Acessado em 06 de abril de 2014, em:

http://pepsic.bvsalud.org/scielo.php?script=sci_arttext\&pid=S0103-

$84862011000200009 \& \operatorname{lng}=$ pt\&tlng=pt. 
Gomes, C., \& Souza, V. L. T. (2012). Psicologia e inclusão escolar: reflexões sobre o processo de subjetivação de professores. Psicologia: Ciência e Profissão, 32(3), 588603. Acessado em 05 de maio de 2014, em: http://www.scielo.br/scielo.php?script=sci_arttext\&pid=S141498932012000300006\&lng=pt\&tlng=pt. 10.1590/S1414-98932012000300006.

Gomes, C., \& Rey, F. L. G. (2007). Inclusão escolar: representações compartilhadas de profissionais da educação acerca da inclusão escolar. Psicologia: Ciência e Profissão, 27(3), 406-417. Acessado em 05 de maio de 2014, em: http://www.scielo.br/scielo.php?script=sci_arttext\&pid=S141498932007000300004\&lng=pt\&tlng=pt. 10.1590/S1414-98932007000300004.

Gusmão, F. A. F., Martins, T. G., \& Luna, S. V. (2011). Inclusão escolar como uma prática cultural: uma análise baseada no conceito de metacontingência. Psicologia da Educação, (32), 69-87. Acessado em 06 de abril de 2014, em: http://pepsic.bvsalud.org/scielo.php?script=sci_arttext\&pid=S1414$69752011000100005 \& \operatorname{lng}=p t \& t \operatorname{lng}=$ pt.

Habermans, J. (2010). El concepto de dignidad humana y la utopia realista de los derechos humano. Diánoia, 55(64), 3-25. Acessado em 05 de abril de 2014, em: http://www.scielo.org.mx/scielo.php?script=sci_arttext\&pid=S018524502010000100001

Heckert, A.C, \& Andrade, R. B. de. (2010). Caminhos bifurcantes na educação inclusiva: inclusões e rebeldias silenciosas na educação pública. Fractal: Revista de Psicologia, 22(3), 497-512. Acessado em 05 de maio de 2014, em:

http://www.scielo.br/scielo.php?script=sci_arttext\&pid=S1984- 
02922010000900004\&lng=pt\&tlng=pt. 10.1590/S1984-02922010000900004.

Jenks, K. M., Lieshout, E. C. D. M. van, \& Moor, J. de (2008). Arithmetic Achievement in Children With Cerebral Palsy or Spina Bifida Meningomyelocele. Remedial and Special Education, 30(6), 323-329.

Jesus, D. M. (2004). Atuando em contexto: o processo de avaliação numa perspectiva inclusiva. Psicologia \& Sociedade, 16(1), 37-49. Acessado em 19 de setembro de 2014, em: http://www.scielo.br/pdf/psoc/v16n1/v16n1a04.pdf

Kang. L. J, Palisano, R. J., Orlin, M. N., Chiarello, L. A., King, G. A., \& Polansky, M. (2010). Determinants of social participation - with friends and others who are not family members - for youths with Cerebral Palsy. Phys Ther, 90, 1743-1757.

Kolk, A., Beilmann, A., Tomberg, T., Napa, A., \& Talvik, T. (2001). Neurocognitive development of children with congenital unilateral brain lesion and epilepsy. Brain \& Development 23, 88-96.

Kolk, A. \& Talvik, T. (2002). Cerebral Lateralization and Cognitive Deficits After Congenital Hemiparesis. Pediatric Neurology, 27(5), 356-362.

Kovacevic, J., \& Dragana, M. P. (2012). Inclusive education: Empirical experience from Serbia. International Journal of Educational Development. 32, 463-470.

Kurth, J. A., \& Keegan, L. (2012). Development and Use of Curricular Adaptations for Students Receiving Special Education Services. J. Spec. Educ. 20(10), 1-13.

Kurth, J. A. \& Mastergeorge, A. M. (2009). Individual Education Plan Goals and Services for Adolescents With Autism: Impact of Age and Educational Setting J. Spec. Educ., 44(3). Acessado em 20, mai. 2014, em: www.sed.sagepub.com

Langerak, N., \& Fieggen, G. (2013) The transition from childhood to adulthood - a challenge in living with Cerebral Palsy. CME, 31(3), 113-114. 
Leahman, L., \& Lava, V. F. (2013). Student Voices Reveal the Complexities of Inclusive Schooling. The Complexities of Inclusive Scholling. 5(1), 547-579.

Leite, L. P., Silva, A. M. da, Mennocchi, L. M., \& Capellini, V. L. M. F. (2011). A adequação curricular como facilitadora da educação inclusiva. Psicologia da Educação, 32, 89-111. Acessado em 06 de abril de 2014, em: http://pepsic.bvsalud.org/scielo.php?script=sci_arttext\&pid=S1414$69752011000100006 \& \operatorname{lng}=$ pt\&tlng=pt.

Leonardo, N. S. T. (2008). Inclusão escolar: um estudo acerca da implantação da proposta em escolas públicas. Psicologia Escolar e Educacional, 12(2), 431-440. Acessado em 05 de maio de 2014, em:

http://www.scielo.br/scielo.php?script=sci_arttext\&pid=S141385572008000200014\&lng=pt\&tlng=pt. 10.1590/S1413-85572008000200014

Lourenço, E., Miranda, C. S. H., \& Póvoa, J. M. (2012). Psicologia e educação inclusiva no Brasil na perspectiva do periódico Psicologia: Ciência e Profissão. Psicologia: Ciência e Profissão, 32(spe), 206-215. Acessado em 06 de maio de 2014 em: http://www.scielo.br/scielo.php?script=sci_arttext\&pid=S141498932012000500015\&lng=pt\&tlng=pt. 10.1590/S1414-98932012000500015

Lundqvist, J. (2014) A Review of Research in Educational Settings Involving Children's Responses. Child Ind Res, 7, 751-768.

Machado, A. C., \& Almeida, M. A. (2010). Parceria no contexto escolar: uma experiência de ensino colaborativo para educação inclusiva. Revista Psicopedagogia, 27(84), 344351. Acessado em 06 de abril de 2014, em: http://pepsic.bvsalud.org/scielo.php?script=sci_arttext\&pid=S0103$84862010000300004 \& \operatorname{lng}=$ pt\&tlng=pt. 
Martins, C. \& Leitão, L. (2012). O aluno com paralisia cerebral no contexto educativo: Diferenciação de metodologias e estratégias. Millenium, 42, 59-66.

Oliveira, M. A., \& Leite, L. P. (2011). Educação inclusiva: análise e intervenção em uma sala de recursos. Paidéia (Ribeirão Preto), 21(49), 197-205. Acessado em 02 de março de 2015, em: http://www.scielo.br/scielo.php?script=sci_arttext\&pid=S0103863X2011000200007\&lng=pt\&tlng=pt. 10.1590/S0103-863X2011000200007.

Martins, I., Oliveira, A. M., \& Amorim, M-A. (2008). From acting to perceiving: mental rotation of body parts. In Proceedings of the 3rd International Conference on Cognitive Science, 1, 105-106.

Melo, P. E., \& Rocha, L. M. (2008). Poder e trabalho na escola: práticas inclusivas em discussão. Psicologia em Revista, 14(2), 81-94. Acessado em 06 de abril de 2014, em: http://pepsic.bvsalud.org/scielo.php?script=sci_arttext\&pid=S1677$11682008000200006 \& \operatorname{lng}=$ pt\&tlng=pt. .

Mendes, M. S. (2013). Da inclusão à evasão escolar: o papel da motivação no ensino médio. Estudos de Psicologia, 30(2), 261-265. Acessado em 05 de maio de 2014, em: http://www.scielo.br/scielo.php?script=sci_arttext\&pid=S0103166X2013000200012\&lng=pt\&tlng=pt. 10.1590/S0103-166X2013000200012.

Montilha, R. de C. I., Temporini, E. R., Nobre, M. I. R. de S., Gasparetto, M. E. R. F., \& José, N. K. (2009). Percepções de escolares com deficiência visual em relação ao seu processo de escolarização. Paidéia (Ribeirão Preto), 19(44), 333-339. Acessado em 05 de maio de 2014, em: http://www.scielo.br/scielo.php?script=sci_arttext\&pid=S0103863X2009000300007\&lng=pt\&tlng=pt. 10.1590/S0103-863X2009000300007.

Muniz, C. (2009). A produção de notações matemáticas e seu significado. In M. H. Fávero 
\& C. Cunha. (Orgs.), Psicologia do Conhecimento: o diálogo entre as ciências e a cidadania (pp.115-143). Brasília: Liber Livro Editora.

Nabuco, M. E. (2010). Práticas institucionais e inclusão escolar. Cadernos de Pesquisa, 40(139), 63-74. Acessado em 12 de abril de 2014, em: http://www.scielo.br/scielo.php?script=sci_arttext\&pid=S0100$15742010000100004 \& \operatorname{lng}=$ pt\&tlng=pt. 10.1590/S0100-15742010000100004.

Nascimento, G. S., Scapim, K. C. de M., \& Silveira, C. A. B. (2010). Inclusão escolar e jogos cooperativos: uma possibilidade de atuação do psicólogo escolar no processo de socialização e integração. Revista da SPAGESP, 11(2), 51-63. Acessado em 06 de abril em: 2014, de http://pepsic.bvsalud.org/scielo.php?script=sci_arttext\&pid=S1677$29702010000200008 \& \operatorname{lng}=$ pt\&tlng=pt. .

Nicolino, V. F., \& Zanotto, M. L. B. (2010). Revisão histórica de pesquisas em Análise do Comportamento e educação especial/inclusão publicadas no Jaba entre 2001 e 2008. Psicologia: teoria e prática, 12(2), 51-79. Acessado em 06 de abril de 2014, em: http://pepsic.bvsalud.org/scielo.php?script=sci_arttext\&pid=S1516$36872010000200005 \& \operatorname{lng}=$ pt\&tlng=pt.

Ohl, N. G., Angelucci, C. B., Nicolau, A. M., \& Honda, C.. (2009). Escolarização e preconceito: lembranças de jovens com e sem deficiência. Psicologia Escolar e Educacional, 13(2), 243-250. Acessado em 05 de maio de 2014, em: http://www.scielo.br/scielo.php?script=sci_arttext\&pid=S1413$85572009000200006 \& \operatorname{lng}=$ pt\&tlng=pt. 10.1590/S1413-85572009000200006. 
Oliver, D. G., Serovich, J. M., \& Mason, T. L. (2005). Constraints and opportunities with interview transcription: Towards reflection in qualitative research. Soc Forces, 84(2), 1273-1289.

Oliveira-Menegotto, L. M., Martini, F. O., \& Lipp, L. K. (2010). Inclusão de alunos com síndrome de Down: discursos dos professores. Fractal: Revista de Psicologia, 22(1), 155-168. Acessado em 05 de maio de 2014, em:

http://www.scielo.br/scielo.php?script=sci_arttext\&pid=S1984-

02922010000100012\&lng=pt\&tlng=pt. 10.1590/S1984-02922010000100012.

Pina Neves, R. da S. (2008). A divisão e os números racionais: uma pesquisa de intervenção psicopedagógica sobre o desenvolvimento de competências conceituais de alunos e professores. Tese (Doutorado em Psicologia) - Universidade de Brasília.

Pina Neves, R. S., \& Fávero, M. H. (2012). A pesquisa de intervenção psicopedagógica: evidências sobre o ensinar e aprender matemática. Linhas Críticas, Brasília, DF, 18(35), 47-68, jan./abr.

Prioste, C. D. (2010). Educação inclusiva e sexualidade na escola: relato de caso. Estilos da Clinica, 15(1), 14-25. Acessado em 06 de abril de 2014, em:

http://pepsic.bvsalud.org/scielo.php?script=sci_arttext\&pid=S1415-

$71282010000100002 \& \operatorname{lng}=$ pt\&tlng=pt.

Radford, L., Schubring, G., \& Seeger, F. (2011). Signifying and meaning-making in mathematical thinking, teaching, and learning. Educational Studies in Mathematics, 77, 49-156.

Rahme, M. M. F. (2010). Movimentos transitivistas em um contexto de inclusão: uma transmissão entre paresTransitivistmovements in an inclusive context: a 
transmissionbetweenpairs. Estilos da Clinica, 15(1), 26-39. Acessado em 06 de abril de 2014, em: http://pepsic.bvsalud.org/scielo.php?script=sci_arttext\&pid=S1415$71282010000100003 \& \operatorname{lng}=$ pt\&tlng=pt. .

Rankin, L. A., \& Kenyon, D. B. (2008). Demarcating Role Transitions as Indicators of Adulthood in the 21st Century: Who Are They? J Adult Dev., 15, 87-92.

Ricardo, L. S., \& Rossetti, C. B. (2012). Inclusão: um enfoque piagetiano sobre as relações de amizade no contexto escolar. Revista Psicopedagogia, 29(90), 301-312. Acessado em 06 de abril de 2014, em:

http://pepsic.bvsalud.org/scielo.php?script=sci_arttext\&pid=S0103$84862012000300004 \& \operatorname{lng}=$ pt\&tlng=pt. .

Ribeiro, J. M. L. C., \& Bastos, A. (2007). O lugar do analista na extensão da psicanálise à inclusão escolar. Estilos da Clínica, 12(23), 26-35. Acessado em 06 de abril de 2014, de http://pepsic.bvsalud.org/scielo.php?script=sci_arttext\&pid=S1415$71282007000200003 \& \operatorname{lng}=$ pt\&tlng=pt.

Rocha, M. A. M., Cabussú, M. A. S. T., Soares, V. G., \& Lucena, R. (2009). Dislexia: atitudes de inclusão. Revista Psicopedagogia, 26(80), 242-253. Acessado em 06 de abril de 2014, em: http://pepsic.bvsalud.org/scielo.php?script=sci_arttext\&pid=S0103$84862009000200009 \& \operatorname{lng}=$ pt\&tlng=pt.

Rodrigues, I. de B., Moreira, L. E. de V., \& Lerner, R.. (2012). Análise institucional do discurso de professores de alunos diagnosticados como autistas em inclusão escolar. Psicologia: teoria e prática, 14(1), 70-83. Acessado em 06 de abril de 2014, em: http://pepsic.bvsalud.org/scielo.php?script=sci_arttext\&pid=S151636872012000100006\&lng=pt\&tlng=pt. . 
Rombo, J. L. (2006). Inclusive education: Polices, teachers' attitudes and perspectives. Contemporary PNG Studies: DWU Research Journal. 5, 29 - 44.

Rooijen, M. van, Verhoeven, L., Smits, D. W., Ketelaar, M., Becher, J. G., \& Steenbergen, B. (2012). Arithmetic performance of children with cerebral palsy: The influence of cognitive and motor factors. Research in Developmental Disabilities, 33, 530-537.

Rooijen, M. V., Verhoeven, L., \& Steenbergen, B. (2010). Early numeracy in cerebral palsy: review and future research. Developmental Medicine \& Child Neurology. 53(3), 202209. DOI: 10.1111/j.1469-8749.2010.03834.x,.

Roriz, T. M. S., Amorim, K. S.; \& Rossetti-Ferreira, M. C. (2005). Inclusão social/escolar de pessoas com necessidades especiais: múltiplas perspectivas e controversas práticas discursivas. Psicologia USP, 16(3), 167-194. Acessado em 06 de abril de 2014, em: http://pepsic.bvsalud.org/scielo.php?script=sci_arttext\&pid=S1678$51772005000300009 \& \operatorname{lng}=$ pt\&tlng=pt.

Rosenbaum, P., Dan, B, Fabiola, R., Leviton, A., Paneth, N. Jocobson, B., Goldstein, M \& Bax, M. (2005). The Definition of Cerebral Palsy. Developmental Medicine and Child Neurology, 47, 571-574.

Rossit, R. A. S., \& Goyos, C. (2009). Deficiência intelectual e aquisição matemática: currículo como rede de relações condicionais. Psicologia Escolar e Educacional, 13(2), 213-225. Acessado em 05 de maio de 2014, em: http://www.scielo.br/scielo.php?script=sci_arttext\&pid=S1413$85572009000200003 \& \operatorname{lng}=$ pt\&tlng=pt. 10.1590/S1413-85572009000200003.

Russo, R. C. de T., Couto, T. H. A. M., \& Vaisberg, T. M. J. A. (2009). O imaginário coletivo de estudantes de educação física sobre pessoas com deficiência. Psicologia \& Sociedade, 21(2), 250-255. Acessado em 05 de maio de 2014, em: 
http://www.scielo.br/scielo.php?script=sci_arttext\&pid=S0102$71822009000200012 \& \operatorname{lng}=$ t\&tlng=pt. 10.1590/S0102-71822009000200012.

Salim, C. M. R. (2001). Iniciação à matemática e a paralisia cerebral: um estudo de caso sobre a aquisição da lógica do sistema numérico e sua notação. [Tese de doutorado não publicada]. Universidade de Brasília, Brasília.

Salim, C. M. R. (2008). A aquisição do sistema numérico em crianças portadoras de necessidades educacionais especiais. Universitas FACE [substituída pela Universitas Humanas], 2(1).

Sanches, A. C. G., \& Oliveira, M. A. F. de. (2011). Educação inclusiva e alunos com transtorno mental: um desafio interdisciplinar. Psicologia: Teoria e Pesquisa, 27(4), 411-418. Acessado em 05 de maio de 2014, em:

http://www.scielo.br/scielo.php?script=sci_arttext\&pid=S0102-

$37722011000400004 \& \operatorname{lng}=$ t\&\&tlng=pt. 10.1590/S0102-37722011000400004.

Sant'Ana, I. M. (2005). Educação inclusiva: concepções de professores e diretores. Psicologia em Estudo, 10(2), 227-234. Acessado em 05 de maio de 2014, em: http://www.scielo.br/scielo.php?script=sci_arttext\&pid=S141373722005000200009\&lng=pt\&tlng=pt. 10.1590/\$1413-73722005000200009

Scorsolini-Comin, F., \& Amorim, K. de S. (2010). "Em meu gesto existe o teu gesto": corporeidade na inclusão de crianças deficientes. Psicologia: Reflexão e Crítica, 23(2), 261-269. Acessado em 05 de maio de 2014, em:

http://www.scielo.br/scielo.php?script=sci_arttext\&pid=S0102$79722010000200008 \& \operatorname{lng}=$ t\&tlng=pt. 10.1590/S0102-79722010000200008.

Sekkel, M. C., Zanelatto, R., \& Brandão, S. B. (2010). Uma questão para a educação inclusiva: expor-se ou resguardar-se? Psicologia: Ciência e Profissão, 30(2), 296-307. 
Acessado em 05 de maio de 2014, em:

http://www.scielo.br/scielo.php?script=sci_arttext\&pid=S141498932010000200006\&lng=pt\&tlng=pt. 10.1590/S1414-98932010000200006

Silva, C. L., \& Leme, M. I. S. (2009). O papel do diretor escolar na implantação de uma cultura educacional inclusiva. Psicologia: Ciência e Profissão, 29(3), 494-511. Acessado em 07 de junho de 2014, em: http://www.scielo.br/scielo.php?script=sci_arttext\&pid=S141498932009000300006\&lng=pt\&tlng=pt. 10.1590/S1414-98932009000300006

Souza, A. M. L., \& Macedo, M. C. S. R. (2012). Avaliação da aprendizagem e inclusão escolar: a singularidade a serviço da coletividade. Psicologia Escolar e Educacional, 16(2), 283-290. Recuperado em 05 de maio de 2014, de http://www.scielo.br/scielo.php?script=sci_arttext\&pid=S1413$85572012000200011 \& \operatorname{lng}=$ pt\&tlng=pt. 10.1590/S1413-85572012000200011.

Souza, C. M. L. de, Hueara, L., Batista, C. G., \& Laplane, A. L. F. de. (2010). Formação de conceitos por crianças com necessidades especiais. Psicologia em Estudo, 15(3), 457-466. Acessado em 05 de maio de 2014, em:

http://www.scielo.br/scielo.php?script=sci_arttext\&pid=S1413$73722010000300003 \& \operatorname{lng}=$ pt\&tlng=pt. 10.1590/S1413-73722010000300003.

Stellin, R. M. R., Martins, L. T., Triandopolis, G. P., \& Costa, E. P. (2009). Infância e normatização: lugar de criança e o discurso social da inclusão e exclusão. Estilos da Clinica, 14(26), 192-215. Acessado em 06 de abril de 2014, em: http://pepsic.bvsalud.org/scielo.php?script=sci_arttext\&pid=S141571282009000100012\&lng=pt\&tlng=pt. . 
Tada, I. N. C., Lima, V. A. A., Melo, T. G., \& Correio, D. Y. V. T. (2012). Conhecendo o processo de inclusão escolar em Porto Velho - RO. Psicologia: Teoria e Pesquisa, 28(1), 65-69. Acessado em 05 de maio de 2014, em:

http://www.scielo.br/scielo.php?script=sci_arttext\&pid=S0102-

$37722012000100008 \& \operatorname{lng}=$ pt\&tlng=pt. 10.1590/S0102-37722012000100008.

Tessaro, N. S., Waricoda, A. S. R., Bolonheis, R. C. M., \& Rosa, A. P. B. (2005). Inclusão escolar: visão de alunos sem necessidades educativas especiais. Psicologia Escolar e Educacional, 9(1), 105-115. Acessado em 05 de maio de 2014, em: http://www.scielo.br/scielo.php?script=sci_arttext\&pid=S1413$85572005000100010 \& \operatorname{lng}=$ pt\&tlng=pt. 10.1590/S1413-85572005000100010.

Tian, W., Jomarkon, P., \& Singhasiri, W. (2010). Designing a transcription system for face to face $\mathrm{PhD}$ supervisory discourse: A selective-specificity model. Proceedings of the International Conference: Doing Research in Applied Linguistic. Acessado em 05 de maio de 2014, em: http://arts.kmutt.ac.th/dral/PDF\%20CD\%20on\%20Web/108119_Designing_a_Transcription_System_for_Face-to-face.pdf.

Travi, Ma. G. G., Oliveira-Menegotto, L. M., \& Santos, G. A. (2009). A escola contemporânea diante do fracasso escolar. Revista Psicopedagogia, 26(81), 425-434. Acessado em 06 de abril de 2014, em: http://pepsic.bvsalud.org/scielo.php?script=sci_arttext\&pid=S0103$84862009000300010 \& \operatorname{lng}=$ pt\&tlng=pt. .

Veltrone, A. A., \& Mendes, E. G. (2011). Descrição das propostas do Ministério da Educação na avaliação da deficiência intelectual. Paidéia (Ribeirão Preto), 21(50), 
413-421. Acessado em 05 de maio de 2014, em:

http://www.scielo.br/scielo.php?script=sci_arttext\&pid=S0103863X2011000300014\&lng=pt\&tlng=pt. 10.1590/S0103-863X2011000300014

Vergnaud, G. (2009). A contribuição da psicologia nas pesquisas sobre a educação científica, tecnológica e profissional do cidadão. In M. H. Fávero \& C. Cunha. (Orgs.), Psicologia do Conhecimento: o diálogo entre as ciências e a cidadania (pp.39-60). Brasília: Liber Livro Editora.

Vitta, F. C. F. de. (2010). A inclusão da criança com necessidades especiais na visão de berçaristas. Cadernos de Pesquisa, 40(139), 75-93. Acessado em 12 de abril de 2014, em: http://www.scielo.br/scielo.php?script=sci_arttext\&pid=S0100$15742010000100005 \& \operatorname{lng}=$ pt\&tlng=pt. 10.1590/S0100-15742010000100005.

Voltolini, R. (2004). Psicanálise e inclusão escolar: direito ou sintoma? Estilos da Clinica, 9(16), 92-101. Acessado em 06 de abril de 2014, em: http://pepsic.bvsalud.org/scielo.php?script=sci_arttext\&pid=S1415$71282004000100009 \& \operatorname{lng}=\mathrm{pt} \& \operatorname{tlng}=\mathrm{pt}$.

Yang, D., Li, M. F., \& Li, W. (2008). Development of a computerized number sense scale for 3-rd graders: reliability and validity analysis. International Electronic Journal of Mathematics Education, 3(2), 110-124.

Zucoloto, P. C. S. V. (2007). O médico higienista na escola: as origens históricas da medicalização do fracasso escolar. Revista brasileira de crescimento $e$ desenvolvimento humano, 17(1), 136-145. Acessado em 06 de abril de 2014, em: http://pepsic.bvsalud.org/scielo.php?script=sci_arttext\&pid=S0104$12822007000100014 \& \operatorname{lng}=$ pt\&tlng=pt. 


\section{Anexo 1 \\ Termo de Consentimento Livre e Esclarecido}

Você está sendo convidado a participar da pesquisa AS COMPETÊNCIAS MATEMÁTICAS NA INCLUSÃO ESCOLAR: UMA PESQUISA DE INTERVENÇÃO COM ESTUDANTE COM PARALISIA CEREBRAL, de responsabilidade de Aline de Amorim Pinto Chiesa aluno(a) de mestrado da Universidade de Brasília.

O objetivo desta pesquisa é abordar o processo de inclusão escolar do portador de paralisia cerebral, especialmente em relação ao desenvolvimento de suas competências conceituais matemáticas. Assim, gostaria de consultá-lo(a) sobre seu interesse e disponibilidade de cooperar com a pesquisa.

Você receberá todos os esclarecimentos necessários antes, durante e após a finalização da pesquisa, e lhe asseguro que o seu nome não será divulgado, sendo mantido o mais rigoroso sigilo mediante a omissão total de informações que permitam identificálo(a). Os dados provenientes de sua participação na pesquisa, tais como questionários, entrevistas, fitas de gravação ou filmagem, ficarão sob a guarda do pesquisador responsável pela pesquisa.

A coleta de dados será realizada por meio de entrevistas, análise do material escolar e avaliação psicopedagógica, que visa acessar os conhecimentos em matemática do participante. É para estes procedimentos que você está sendo convidado a participar. Sua participação na pesquisa não implica em nenhum risco físico ou psicológico.

Sua participação é voluntária e livre de qualquer remuneração ou benefício. Você é livre para recusar-se a participar, retirar seu consentimento ou interromper sua participação a qualquer momento. A recusa em participar não irá acarretar qualquer penalidade ou perda de benefícios.

Se você tiver qualquer dúvida em relação à pesquisa, você pode me contatar através do telefone (61)8104-6392 ou pelo e-mail alinechiesa@hotmail.com.

A equipe de pesquisa garante que os resultados do estudo serão devolvidos aos participantes por meio de entrega de um relatório, podendo ser publicados posteriormente na comunidade científica.

Este projeto foi revisado e aprovado pelo Comitê de Ética em Pesquisa do Instituto de Ciências Humanas da Universidade de Brasília - CEP/IH. As informações com relação à assinatura do TCLE ou os direitos do sujeito da pesquisa podem ser obtidas através do email do CEP/IH cep_ih@unb.br.Este documento foi elaborado em duas vias, uma ficará com o(a) pesquisador(a) responsável pela pesquisa e a outra com o senhor(a).

Assinatura do (a) participante

Assinatura do (a) pesquisador (a)

Brasília, de de 
Anexo 2

\section{TERMO DE ASSENTIMENTO}

Você está sendo convidado para participar da pesquisa Desenvolvimento de competências numéricas e inclusão escolar: Uma pesquisa de intervenção com adolescente com paralisia cerebral. Seus pais permitiram que você participe.

Quero saber o que um jovem como você sabe sobre matemática. Você não precisa participar da pesquisa se não quiser, é um direito seu, não terá nenhum problema se desistir.

A pesquisa será feita no Laboratório de Psicologia do Conhecimento - COGITO do(a) Departamento de Psicologia Escolar e do Desenvolvimento, do Instituto de Psicologia, da Universidade de Brasília, onde você será entrevistado e fará algumas atividades de matemática junto comigo.

Caso aconteça algo errado, você pode me procurar pelo telefone (61) 8104-6392. Há coisas boas que podem acontecer se você aprender mais coisas sobre matemática.

Ninguém saberá que você está participando da pesquisa, não falaremos a outras pessoas, nem daremos a estranhos as informações que você nos der. Os resultados da pesquisa vão ser publicados, mas sem te identificar.

Quando terminar a pesquisa farei um relatório para sua família e, caso vocês queiram, ele poderá ser compartilhado com sua escola, para ajudá-lo a aprender melhor.

Se você tiver alguma dúvida, você pode me perguntar. Eu escrevi o telefone na parte de cima desse texto.

$\mathrm{Eu}$

aceito participar da pesquisa. Entendi que posso dizer "sim" e participar, mas que, a qualquer momento, posso dizer "não" e desistir que ninguém vai ficar furioso. Os pesquisadores tiraram minhas dúvidas e conversaram com os meus responsáveis.

Recebi uma cópia deste termo de assentimento e li e concordo em participar da pesquisa.

Brasília, de de 
Anexo 3

Autorização CEP para a realização da pesquisa

\section{INSTITUTO DE CIENCIAS \\ HUMANAS / UNIVERSIDADE \\ DE BRASILIA / CAMPUS}

PARECER CONSUBSTANCLADO DO CEP

\section{DADOS DO PROJETO DE PESQUISA}

Titulo da Pesquisa: AS COMPETÉNCIAS MATEMATICAS NA INCLUSARO ESCOLAR: UMA PESQUISA DE INTERVENCHO COM ESTUDANTE COM PARALISIA CEREBRAL

Pesqulsador: Alne de Amorim Pinto Chiesa

Area Tematica:

Versas: 2

CAAE: 39606914.4 .0000 .5540

Institulçaso Proponente: Instituto de Psicologla -UNB

Patrocinador Principal: Flnandamento Proprio

\section{DADOS DO PARECER}

Numero do Parecer: 954.635

Data da Relatorla: 19/02/2015

\section{Apresentaçaso do Projeto:}

O presente projeto de mestrado se centra na historia do processo de Inclusato escolar de um adolescente com paralisla cerebral e no desenvolvimento de suas competenclas matematicas, notadamente en relaçto ao concelto de número, aqul entendido como a compreensalo do significado de nùmeros e operaçbes, o que Impilica num entendlmento do sistema de numeraçăo decimal, incuindo noç5̆ de valor posicional, padrbes numericos e o uso de multiplas formas de representar os nümeros.

O estudo sera realizado com um estudante Inciuso no $6^{\circ}$ ano do Ensino Fundamenta, em escola da rede publica do Distrito Federal, capaz de se comunicar oraimente de forma intellglvel e fuente, do sexo mascullno, com 14 anos de idade. Procederemos a coleta de quatro tipos de dados: o material escolar (cadernos, boletins e relat:orios),

entrevistas seml estruturadas com foco na namativa do estudante sobre seu historico de escolarizaçâto, a avalaçấo e a intervençăo psicopedagoglca.

O material escolar sera analsado em sua forma e em seu conteudo, com foco nas aftuidades matenatcas.

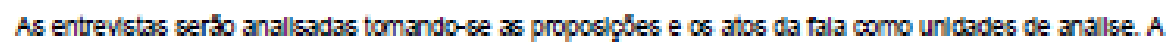
analse da avalaçăo e da intervençăo psicopedagogica terăo como foco a fllaçâo entre competencias e

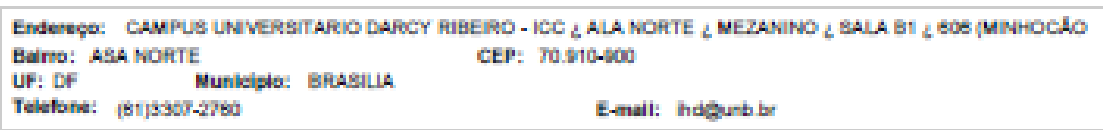




\section{INSTITUTO DE CIENCIAS HUMANAS / UNIVERSIDADE DE BRASÍLIA / CAMPUS}

Conthacks do Pancer setans

difculdades do estudante, a analse das attwdades propostas e a analse da natureza das Interaçbes entre participante e pesqulsadora.

A pesquisa sera feita no Laboratorio de Psicologla do Conhecimento - CoGITO do(a) Departamento de Psicologia Escolar e do Desenvolvimento, do Instituto de Psicologla, da Universidade de Braslla

Objetivo da Pesquisa:

Pesquisar o processo de desenvolvimento de competenclas conceltuals matematicas de um aluno com paralsala cerebral por melo de uma pesquisa de Intervençăo psicopedagogica.

Avallaça dos Rlscos $\theta$ Benencios:

A pesquisadora avalla que a pesquisa năo oferece riscos, afirma garantir o anonimato do aluno, porem afima no Termo de Assentimento que podera propiciar a devoiuç5̆o do resuitado de pesquisa para a escoia que 0 adolescente frequenta com previa autortzaçăo.

Comentarios $\theta$ Consideraç0 08 sobre a Pesqulea:

A pesqulsadora ainda aflma no Termo de Assentimento "Ninguem sabera que voce esta participando da pesqulsa, năo falaremos a outras pessoas, nem daremos a estranhos as informaçbes que voce nos der. Os resultados da pesquisa văo ser publicados, mas te identificar:"

Consideraçচes sobre 08 Termos de apresentaçåo obrigatorla:

Os termos apresentados:

- TCLE adequados

- aceite Insthucional

- Termo de Uso de Imagem e voz

- Termo de assentmento

Recomendaços:

Nenhuma recomendaçăo.

Conclusdes ou Pendinclas $\theta$ Llata de Inadequsçoes:

A pesquisadora atendeu 36 recomencaçbes assegurando os preceltos eticos.

situaça do Parecer:

Aprovado

Endesepo: CAMPUS LNUVRSTAFIO DAFCY RIBERO - ICC $\angle$ ALA NOFTE $\angle$ MEZANINO $\angle$ SALA BI $\angle$ EOE (MiNHOCLO Baino: ABA NOPTE

UF: DF Munkiglo: BRasilla CEP: ro.sto-too

Telefore: [B1]39607-2760 E-mall: hdgunbr 
INSTITUTO DE CIENCIAS

HUMANAS / UNIVERSIDADE

DE BRASÍLIA / CAMPUS

Conthacks to Pancer sei.ase

Necessita Apreclaçäo da CONEP:

N550

Consideraç0es Finals a criterio do CEP:

BRASILIA, 13 de Feverelro de 2015

Assinado por:

LWla Barbose

(Coordenador) 


\begin{abstract}
Anexo 4
ECPN (Épreuve conceptuelle de résolution des problèmes numériques)
\end{abstract}

\title{
1- MATERIAL
}

- 40 fichas da mesma cor e tamanho (ou grandes botões, tampinhas de garrafas todas da mesma cor e do mesmo tamanho, etc.)

- Três figurinhas (ou miniaturas encontradas em lojas de brinquedos: um gato, um cachorro e um coelhinho, ou semelhante).

- Uma caixa de reserva (uma caixa de sapato, por exemplo).

\section{2- DESENVOLVIMENTO DA PROVA}

\section{1/ Configuração de partida}

Colocamos diante do sujeito três punhados de fichas que são distribuídas a cada uma das três figuras (aqui vamos nos referir a gato, cachorro e coelho) como abaixo. Uma caixa de reserva com 20 fichas é colocada à sua disposição.

- 2 fichas para o gato;

- 3 fichas para o cachorro;

- 7 fichas para o coelho;

\section{2/ OS ITENS}

Item 1 - DESCREVER A SITUAÇÃO

"Aqui está o gato, aqui o cachorro e aqui o coelho; aqui estão as fichas de cada um. O que podemos dizer sobre o que temos aqui?"

\section{Item 2 - QUEM TEM MAIS?}

“Quem tem mais fichas? Como você sabe?"

Em caso de dificuldade, colocam-se as mesmas questões diante de pares, no lugar do trio: por exemplo, o gato e o cachorro. E se retoma a questão:

\section{Quem tem mais? Como que você sabe?}

\section{Item 3: TODOS PARECIDOS}

Retomar a situação de partida com as três figuras.

- 2 fichas para o gato;

- 3 fichas para o cachorro;

- 7 fichas para o coelho; fichas?”

"O que podemos fazer para que todos eles tenham a mesma quantidade de 
Qualquer que seja a resposta do sujeito e sobretudo no caso de sucesso, três saídas são propostas para incitá-lo a mudar a estratégia. Por exemplo, se ele juntar àquele que tem menos, perguntar:

"Você poderia fazer diferente para que eles todos fiquem com o mesmo tanto de fichas? Ou, “com o mesmo número de fichas?”

Item 4: "A MAIS QUE", À PARTIR DE ESTADOS INICIAIS DIFERENTES (DE UM CONJUNTO) E A PARTIR DE ESTADOS INICIAIS IDÊNTICOS.

Apresentamos ao sujeito uma nova distribuição:

- 3 fichas para o gato;

- nenhuma ficha para o cachorro.

- 7 fichas para o coelho

a) "Faça alguma coisa para que o cachorro tenha quatro a mais que o gato".

b) "Faça alguma coisa para que o cachorro tenha uma a mais que o gato".

Modifica-se a distribuição:

- 4 fichas para o gato

- 4 fichas para o cachorro

- 7 fichas para o coelho.

“Faça alguma coisa para que o cachorro tenha três a mais que o gato".

Item 5 - "MAIS QUE" COM “LOGRO” NUMÉRICO (AQUILO QUE É DADO COMO DIFERENÇA NÃO CORRESPONDE AO AJUNTAMENTO PEDIDO).

Nova distribuição:

- 4 fichas para o gato

- 7 fichas para o cachorro

- 7 fichas para o coelho

“Faça alguma coisa para que o coelho tenha 5 a mais que o gato".

Item 6- PESQUISA DO ESTADO INICIAL

Escondemos na mão fechada três fichas.

“Eu escondi algumas fichas na minha mão e vamos descobrir juntos quantas eu escondi”.

Acrescentamos ostensivamente 4 fichas na mão fechada que contem as outras 3 dizendo:

"Eu tenho fichas escondidas na minha mão fechada e agora vou colocar mais fichas. Preste bem atenção e conte comigo as que eu vou colocando".

Podemos convidar o sujeito para contar juntos: 1,2,3,4. 
“Agora eu tenho sete fichas na minha mão. Quantas eu tinha no começo?”

Caso o sujeito não responda corretamente, abrimos a mão que contem as fichas convidamos o sujeito para contá-las e fazemos novamente a pergunta:

\section{“Quanto eu tinha no começo, quando minha mão estava fechada?”}

\section{Item 7 - TRANSFORMAÇÃO NEGATIVA}

Colocamos 5 fichas em uma das mãos, convidando o sujeito para contá-las junto conosco. Depois retiramos duas fichas sem que o sujeito veja. Apresentamos a mão fechada com as três fichas restantes e declaramos:

“Eu fiz uma coisa que você não viu, e agora eu tenho 3 fichas na minha mão. $O$ que eu fiz?"

Caso o sujeito não responda corretamente, repetimos a questão com a mão aberta. 